Universidade de São PaUlo

FACULDADE DE EDUCAÇÃO

\title{
DO CONTROLE DAS PAIXÕES À MAESTRIA DE SI: UM ESTUDO ACERCA DAS PRÁTICAS E DAS REPRESENTAÇÕES DE MORALIZAÇÃO NA ESCOLA PÚBLICA PAULISTA \\ (1948 - 1978)
}

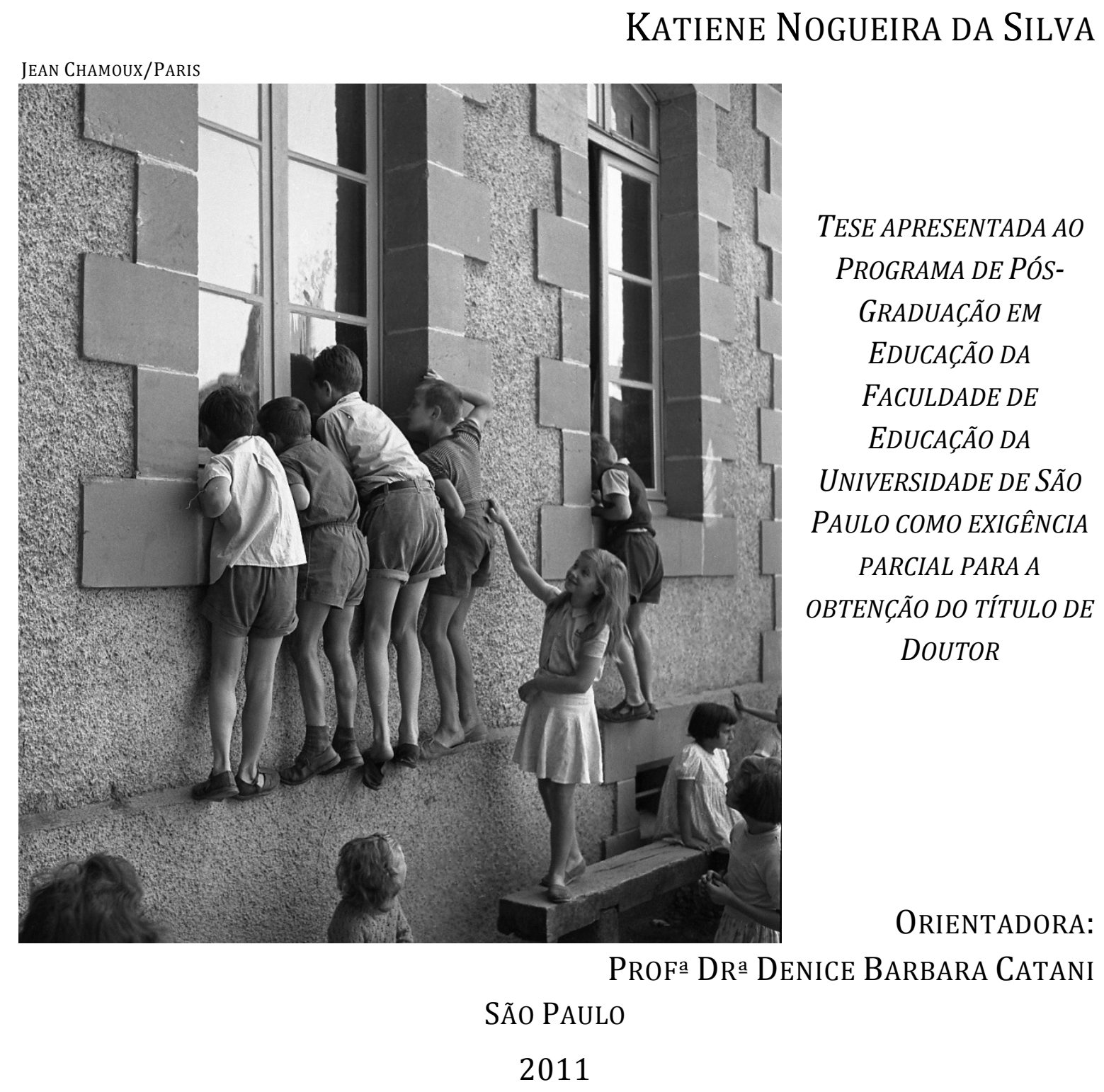


AUTORIZO A REPRODUÇÃO E DIVULGAÇÃO TOTAL OU PARCIAL DESTE TRABALHO, POR QUALQUER MEIO CONVENCIONAL OU ELETRÔNICO, PARA FINS DE ESTUDO E PESQUISA, DESDE QUE CITADA A FONTE.

Catalogação na Publicação

Serviço de Biblioteca e Documentação

Faculdade de Educação da Universidade de São Paulo

37(09) Silva, Katiene Nogueira da

S586d Do controle das paixões à maestria de si: um estudo acerca das práticas e das representações de moralização na escola pública paulista (19481978) / Katiene Nogueira da Silva; orientação Denice Barbara Catani. São Paulo: s.n., 2011.

$289 \mathrm{p}$.

Tese (Doutorado - Programa de Pós-Graduação em Educação. Área de Concentração: História da Educação e Historiografia) - - Faculdade de Educação da Universidade de São Paulo.

1. História da educação 2. Educação moral 3. Democratização do ensino 4. Professores 5. Representação I. Catani, Denice Barbara, orient. 
UNIVERSIDADE DE SÃo PAULO

FACULDADE DE EDUCAÇÃO

\section{DO CONTROLE DAS PAIXÕES À MAESTRIA DE SI: UM ESTUDO ACERCA DAS PRÁTICAS E DAS REPRESENTAÇÕES DE MORALIZAÇÃO NA ESCOLA PÚBLICA PAULISTA}

(1948 - 1978)

Katiene Nogueira da Silva

Tese apresentada aO Programa de PósGraduaÇão EM EduCAÇÃo dA FaCUldade DE EDUCAÇÃO DA UNIVERSIDADE DE SÃo PAULO COMO EXIGÊNCIA PARCIAL PARA A OBTENÇÃO DO TÍTULO DE DOUTOR

ORIENTADORA:

Profa Dra Denice BARbara CATANi

SÃO PAULO

2011 
Para os meus pais 


\section{RESUMO}

SILVA, Katiene Nogueira da. Do controle das paixões à maestria de si: um estudo acerca das práticas e das representações de moralização na escola pública paulista (1948-1978), tese de doutorado, FEUSP, 2011, 289p.

Este trabalho busca compreender mediante a perspectiva sócio-histórica como foram configuradas e mobilizadas as práticas e as representações de moralização na escola pública paulista em um período que compreende a democratização das oportunidades de educação e que alterou o modelo de escola que era mantido desde a época republicana. O termo "moralização" é entendido como a moral destinada a ser incorporada pelos indivíduos. A idéia do poder sobre si mesmo exercido a partir do interior é especialmente fértil para a compreensão das práticas e das representações de moralização na escola pública paulista durante o período investigado. Além da diversidade em relação à clientela que passou a ocupar o espaço escolar, a origem social dos professores primários também mudou. Para governar as massas e gerir a diversidade no interior das instituições escolares durante a expansão do ensino, foi importante levar cada um a governar a si próprio, o que consistiu num elemento necessário à própria existência da democratização do acesso à educação pública. A escolha do ano de 1948 como marco inicial para o estudo deve-se a ser este o ano de início da "Campanha de Defesa da Escola Pública". Trata-se um movimento cívico importante na história da escola pública brasileira e que culminou, em 1961, com a promulgação da LDB $\mathbf{n}^{\mathbf{0} 4.024}$. O período compreendido por este trabalho encerra-se em 1978, quando mudanças no comportamento dos professores ganharam visibilidade a partir do momento em que os mesmos aderiram a uma greve, ainda no regime militar, à revelia das entidades que os representavam, como a Associação dos Professores do Ensino Oficial do Estado de São Paulo (APEOESP) e o Centro do Professorado Paulista (CPP). As fontes escolhidas, os manuais de didática e metodologia do ensino, as revistas pedagógicas e a legislação vigente no período, permitiram conhecer melhor os discursos veiculados, as normas e a obrigatoriedade referentes às práticas e às condutas nas escolas assim como as orientações dadas aos professorandos e depois aos professores sobre como deveria ser realizado o trabalho docente, visando a oferecer a formação considerada "adequada" aos alunos. Ao longo do exame das fontes consultadas, foi possível perceber que as práticas de moralização eram diversas e a sua justificativa era fundamentada mediante variados discursos, que obedeciam a três eixos principais: psicológico, religioso e cívico. Portanto, as principais evidências indicam que, para que as representações acerca da idéia de "moral" fossem transformadas em práticas nas escolas, era necessário evocar um discurso legitimado pela idéia de autocontrole, de Deus e de nação.

Palavras-chave: história da educação - práticas e representações de moralização expansão do ensino paulista - história da profissão docente - práticas escolares 


\begin{abstract}
SILVA, Katiene Nogueira da. Do controle das paixões à maestria de si: um estudo acerca das práticas e das representações de moralização na escola pública paulista (1948-1978), doctoral thesis, FEUSP, 2011, 289p.
\end{abstract}

This work seeks to understand the socio-historical perspective as were configured and deployed practices and representations of moralizing in public school in São Paulo that period comprises the democratization of educational opportunities and that changed the school model that was kept from the Republican era. The term "morality" is understood as the moral to be incorporated by individuals. The idea of power about yourself exercised from the interior is especially important for the understanding of practices and representations of moralizing in public school during the period investigated. Besides the diversity in relation to people who moved to the school environment, the social origin of primary teachers has also changed. To govern the people and manage diversity within educational institutions during the expansion of higher education, it was important to take each one to govern itself, which was a necessary element for the existence of the democratization of access to public education. The choice of the year in 1948 as a milestone for the study is due to be the year of initiation of the campaign for defence of public school. This is an important civic movement in the history of Brazilian public school, and which culminated in 1961, with the promulgation of the LDB $\mathbf{n}^{\mathbf{0}}$ 4.024. The period for this work ends in 1978, when changes in the behaviour of teachers have gained visibility since they joined the strike, even in the military regime, in absentia of the entities that represent, as the Associação dos Professores do Ensino Oficial do Estado de São Paulo (APEOESP) and the Centro do Professorado Paulista (CPP). The fonts you choose, didactic manuals and methodology of teaching, pedagogical magazines and the law of the period, enabled a better understanding of the speeches delivered, the standards and requirements concerning practices and to conduct schools as well as the guidelines given to students and then to teachers about how work should be accomplished teaching to provide training considered "proper" students. Throughout the examination of the sources consulted, it was possible to realize that morals were diverse and its justification was given by various speeches, which were the three main axes: psychological, religious and civic. Therefore, the main evidence indicates that for representations about the idea of "morals" were transformed into practice in schools, it was necessary to evoke a speech legitimized by the idea of self-governance, God and the nation.

Keywords: history of education - practices and representations of moralizing - expansion of teaching in São Paulo - history of the teaching profession - school practices 


\section{AgRAdeCIMENTOS}

Agradeço ao Conselho Nacional de Desenvolvimento Científico e Tecnológico (CNPq), que investiu na minha formação no Brasil e no exterior, mediante a bolsa de estudos concedida para a realização do estágio junto ao Service d’Histoire de 1'Éducation (SHE) do Institut National de Recherche Pédagogique (INRP), e cujo financiamento foi fundamental para a realização deste trabalho.

Agradeço imensamente à professora Denice Barbara Catani pela dedicação com que cuida da minha formação há 12 anos, por ter me apresentado a possibilidade de fazer pesquisa quando eu ainda estava no primeiro ano da graduação, pela amizade, por toda a sua generosidade, por ter acreditado no meu trabalho, pelo privilégio em ter podido conviver e aprender com ela durante todos esses anos e por ter me ensinado os elementos que considero mais fascinantes da docência e da pesquisa: o muito que se aprende enquanto se ensina e o quanto se aprende sobre si próprio enquanto se investiga.

Agradeço ao professor Pierre Caspard por ter me acolhido junto ao Service d'Histoire de l'Éducation (SHE) do Institut National de Recherche Pédagogique (INRP) para a realização do meu estágio, pelas valiosas sugestões que permitiram um enriquecimento teórico ao meu trabalho, pela maneira dedicada como cuidou da minha formação e pela disponibilidade em atender às minhas questões durante todo o ano em que estive em Paris.

Agradeço ao professor Celso de Rui Beisiegel, por quem tenho profundo respeito e admiração desde que fui sua aluna pela primeira vez, quando cursava o primeiro ano de Pedagogia. O professor está entre os meus "professores marcantes" e é uma grande honra tê-lo em minha banca. Também o agradeço por acompanhar o desenvolvimento da minha pesquisa e pelas sugestões valiosas feitas durante o Exame Geral de Qualificação.

Agradeço à Rosario Silvana Genta Lugli, pelo incentivo, por acompanhar o meu trabalho e pelas sugestões férteis realizadas durante o Exame Geral de Qualificação. 
Agradeço à professora Anne-Marie Chartier e ao professor Jean Hébrard por toda a atenção dispensada a mim e pela disponibilidade em discutir o meu trabalho durante a realização de todo o meu estágio no exterior, que muito enriqueceram a minha pesquisa.

Agradeço a toda a equipe de pesquisadores e funcionários do Service d'Histoire de l'Éducation (SHE) do Institut National de Recherche Pédagogique (INRP) pela forma acolhedora como me receberam durante o meu estágio, sou extremamente grata especialmente à Nanou, à Pénélope Caspard-Karydis, ao Arille Agbo, ao Eric Dumas, ao Cyril Mathevon, ao Henri Chamoux e ao Vincent Alamercery pelas conversas, pela companhia, pela gentileza dispensada a mim e pela forma como sempre me ajudaram. Agradeço especialmente ao Henri Chamoux também por ter me cedido gentilmente a fotografia que está na capa desta tese, que foi feita pelo seu pai, o fotógrafo Jean Chamoux.

Agradeço aos professores Antoine Prost, François Dubet, Jean-Noël Luc, SophieHélène Trigeaud e Roger Chartier pelas valiosas contribuições teóricas e por terem me recebido nos cursos e seminários que ministraram durante o ano em que estive em Paris.

Agradeço à Paula Perin Vicentini, por acompanhar a minha trajetória acadêmica, pela forma gentil como sempre me ajudou e pela disponibilidade em ler os meus trabalhos.

Agradeço profundamente aos meus pais, Katia e Benedito José, às minhas avós Gertrudes e Wanda, às minhas irmãs Beatriz e Laís e ao meu sobrinho Peahi por todo o amor que sempre dispensaram a mim, pelo qual eu serei sempre grata, por me incentivarem sempre e para quem eu dedico todas as minhas conquistas.

Agradeço também a todos os meus tios e tias, primos e primas, amigos e amigas que acompanharam de perto e torceram muito para a realização deste trabalho. 


\section{SUMÁRIO}

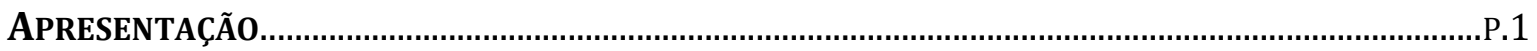

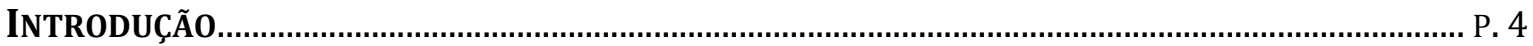

OS MODOS DE PRODUÇÃO DO TRABALHO............................................................................... P. 26

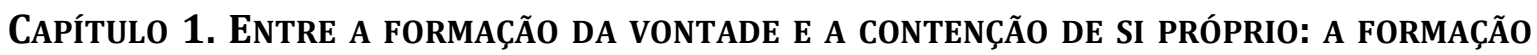
MORAL NO ÂMBITO DO AUTOGOVERNO................................................................................ P. 68

1.10 CONTROLE DA VIDA ÍNTIMA E DA ALMA: ENSINAR A “AMAR O QUE TEMOS QUE AMAR E A ODIAR O QUE TEMOS QUE ODIAR". P. 79

1.2 Do AUTOCONTROLE OU DA MORALIZAÇÃO DAS PAIXÕES.............................................................. P. 82

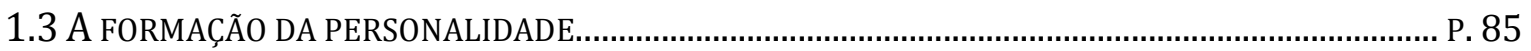

1.4 ENTRE CONDUZIR E CONFORMAR: DO ESTÍMULO À “CAPACIDADE CRIADORA DO INDIVÍDUO” À PADRONIZAÇÃO DAS CONDUTAS.................................................................................................. P. 90

1.5 A FELICIDADE: UM DIREITO OU UMA OBRIGAÇÃO? ..................................................................... P. 97

1.6 A FORMAÇÃO DO CARÁTER E A LUCIDEZ EM TORNO DE SI............................................................. P. 98

1.7 OS PAPÉIS QUE CABERIAM AOS HOMENS E ÀS MULHERES........................................................... P. 102

CAPÍtUlo 2. ARAUTOS DA MORAL, DA DECÊNCIA E DAS VIRTUDES: AS PROFESSORAS PRIMÁRIAS COMO EXEMPLO DE CONDUTA......................................................................................................... P. 105

2.1 O MAGISTÉRIO PRIMÁRIO: UMA PROFISSÃO DE FÉ..................................................................... P. 118

2.2 A SAÚDE E A APRESENTAÇÃO DAS PROFESSORAS PRIMÁRIAS: “SEJA UM EXEMPLO VIVO DAQUILO QUE EXIGE DOS SEUS ALUNOS". P. 126

2.3 A "MATERNIDADE ESCOLAR": AS PROFESSORAS COMO MÃES. P. 130 
3.4 AS MÚSICAS E OS HINOS PÁTRIOS: EDUCANDO O OUVIDO OU “DAS EXIGÊNCIAS ARTÍSTICAS DA MORALIZAÇÃO" P. 157

3.5 A LITERATURA NA CONFORMAÇÃO MORAL OU POR “UMA LEITURA SADIA E BEM ORIENTADA" P. 160

3.6 OS MUSEUS E A HISTÓRIA PÁTRIA: “O MUSEU COMO SISTEMA DE MEMORIZAÇÃO VITAL À CONTINUIDADE DO PROCESSO CIVILIZATÓRIO" P. 164

3.7 A HOMOGENEIZAÇÃO E A CULTURA COMO “INSTRUMENTO DE COMUNHÃO" P. 166

3.8 DOS CASTIGOS FÍSICOS AO MANEJO DA CLASSE P. 169

\section{CAPÍTULO 4. MORALIZAÇÃo E RELIGIÃO: ENTRE A LAICIDADE PROCLAMADA E A PERMANÊNCIA DA} VELHA ORDEM

4.1 O PERIGO DOS MEIOS DE COMUNICAÇÃO: PARA “NÃO DESPERTAR UMA CURIOSIDADE PREMATURA E MALSÃ" P. 198

4.2 O PROFESSOR SACERDOTE: AQUELE “QUE ABRE OU FECHA AS PORTAS DO CÉU” P. 204

4.3 A PREPARAÇÃO PARA A VIDA EM COMUNIDADE E A VALORIZAÇÃO DA FAMÍLIA: “O VALOR DO POVO SE BASEIA NO VALOR DAS MÃES". P. 209 
5.1 A EDUCAÇÃO, O TRABALHO E A MOBILIDADE SOCIAL.............................................................. P. 226

5.2 A ADEQUAÇÃO DAS CRIANÇAS À SOCIEDADE............................................................................ P. 234

5.3 A EDUCAÇÃO E A DEMOCRACIA......................................................................................... P. 237

5.4 A CRISE POR CONTA DA MUDANÇA DOS VALORES SOCIAIS......................................................... P. 240

5.5 A EDUCAÇÃO E A LIBERDADE: “TODA VERDADEIRA LIBERDADE É DISCIPLINA DE SI

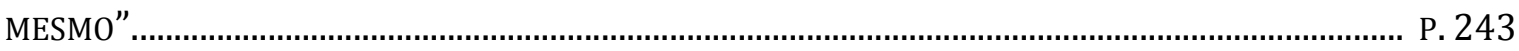

5.6 A ESCOLA COMO UMA “SOCIEDADE EM MINIATURA”............................................................. P. 245

5.7 A MORALIZAÇÃO E A EDUCAÇÃO MORAL E CÍVICA..................................................................... P. 248

5.8 A EDUCAÇÃO E A SEGURANÇA NACIONAL.................................................................................. P. 258

5.9 A PÁTRIA E O NACIONALISMO_.................................................................................................. P. 261

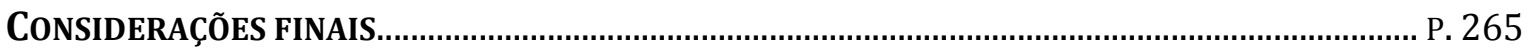

REFERÊNCIAS BIBLIOGRÁFICAS.................................................................................................. P. 278 
“O passado é mentira. Metade é feita de coisas não passadas. A outra metade é feita de coisas que nunca mais passarão.”

Mia Couto 


\section{APRESEnTAÇÃo}

Este trabalho busca compreender mediante a perspectiva sócio-histórica como foram configuradas e mobilizadas as práticas e as representações de moralização na escola pública paulista em um período marcado pela democratização das oportunidades de educação e que mudou as configurações da estrutura do ensino, que passou a receber professores das mais diversas origens sociais e formações profissionais e que trouxe a heterogeneidade para dentro da sala de aula, com o ingresso de uma clientela escolar distinta da que anteriormente freqüentava os bancos escolares, o que repercutiu não apenas na configuração do espaço escolar como também no exercício do trabalho docente, alterando o modelo de escola que era mantido desde a época republicana. O termo "moralização" é entendido neste estudo como a moral que visa a ser praticada, e que é inculcada no comportamento das pessoas. A idéia do poder sobre si exercido a partir do interior é especialmente fértil para a compreensão das práticas e das representações de moralização na escola pública paulista durante o período investigado. Isto porque, no momento de expansão das oportunidades de educação pública, as portas das escolas se abriram para as massas. Além da diversidade em relação à clientela que passou a ocupar o espaço escolar, a origem social dos professores primários também mudou. Pensar a questão mediante a ótica do autogoverno permite entender melhor o quanto, na dificuldade de governar as massas e gerir a diversidade no interior das instituições escolares durante a democratização do ensino, foi importante levar cada um a governar a si próprio: não apenas nas escolas primárias, mas também nos cursos de formação de professores, nas escolas normais e depois nos cursos de magistério. Conformar moralmente as docentes a tal ponto que elas fossem consideradas exemplos que deveriam ser seguidos pelos alunos e torná-las tão amáveis e ternas até que tivessem a sua identidade confundida com a figura materna - consistindo numa das características do habitus das professoras primárias - parecem ter sido estratégias que visavam não apenas à formação das crianças, mas que também tinham por objetivo controlar o trabalho docente. Desta forma, o autogoverno conquistado mediante o processo de conformação moral dos indivíduos, como será demonstrado ao longo deste trabalho, parece ter sido um elemento 
necessário à própria existência da democratização das oportunidades de educação pública. A escolha do ano de 1948 como marco inicial para o presente estudo deve-se ao ano de início da "Campanha de Defesa da Escola Pública". Trata-se de um movimento cívico importante na história da escola pública brasileira e que culminou, em 1961, com a promulgação da LDB $\mathbf{n}^{\mathbf{0} 4.024}$. O período compreendido por este trabalho encerra-se em 1978, quando mudanças no comportamento dos professores ganharam visibilidade a partir do momento em que os mesmos aderiram a uma greve, ainda no regime militar, à revelia das entidades que os representavam, como a Associação dos Professores do Ensino Oficial do Estado de São Paulo (APEOESP) e o Centro do Professorado Paulista (CPP). As fontes escolhidas, os manuais de didática e metodologia do ensino, as revistas pedagógicas e a legislação vigente no período, permitiram conhecer melhor os discursos veiculados, as normas e a obrigatoriedade referentes às práticas e às condutas nas escolas assim como as orientações dadas aos professorandos e depois aos professores sobre como deveria ser realizado o trabalho docente, visando a oferecer a formação considerada "adequada" aos alunos. Ao longo do exame das fontes consultadas, foi possível perceber que as práticas de moralização eram diversas e a sua justificativa era fundamentada mediante variados discursos, que obedeciam a três eixos principais: psicológico, religioso e cívico. Portanto, as principais evidências indicam que, para que as representações acerca da idéia de "moral" fossem transformadas em práticas nas escolas, era necessário evocar um discurso que é legitimado pela idéia de autocontrole, de Deus e de nação.

Quanto à estrutura geral assumida pela tese, no início há a "Apresentação", na qual são descritos brevemente os objetivos da investigação e a estrutura da tese, a "Introdução", que anuncia alguns dos referenciais teóricos que foram mobilizados para a análise da questão proposta ao longo dos capítulos e "Os modos de produção do trabalho", no qual são apresentadas as fontes consultadas e a forma como as mesmas foram exploradas e incorporadas ao estudo. A divisão dos capítulos foi estabelecida a partir dos três eixos principais, enunciados anteriormente: o psicológico, que deu origem aos capítulos 1 "Entre a formação da vontade e a contenção de si próprio: a formação moral no âmbito do autogoverno", 2 "Arautos da moral, da decência e das virtudes: as professoras primárias como exemplo de conduta" e 3 "Práticas escolares com a finalidade de moralizar", o religioso, que deu origem ao capítulo 4 "Moralização e religião: entre a laicidade proclamada e a permanência da velha ordem" e o cívico, que deu origem ao capítulo 5 
"Educação moral. E cívica? Estado, nação e patriotismo"; e um esforço de síntese busca retomar os principais elementos explicativos a que se chegou, sob a forma de "Considerações finais". Cabe ressaltar que a divisão a partir dos três eixos não equivale a uma separação radical entre as esferas da educação moral, e sim quer ajudar a compreender como as dimensões psicológica, religiosa e cívica integram-se para produzir processos de moralização. Com esta perspectiva buscou-se organizar a separação da análise nos diversos capítulos.

O primeiro capítulo busca demonstrar como as práticas e as representações de moralização foram evidenciadas através das fontes consultadas mediante a perspectiva do autogoverno. O segundo capítulo analisa a maneira pela qual o comportamento das professoras primárias era controlado e mobilizado de modo a contribuir não apenas à sua conformação moral, mas também à moralização dos seus alunos, representando exemplos que deveriam ser seguidos pelas crianças. No terceiro capítulo são discutidas algumas práticas que, para além dos objetivos pedagógicos explicitados, também tinham a finalidade de moralizar, como é o caso, por exemplo, dos castigos, do manejo da classe, dos exames e do ensino de disciplinas como música e história. O quarto capítulo apresenta uma discussão acerca da maneira pela qual o discurso cívico e o governo militar apropriam-se dos valores cristãos para manejar a conduta dos indivíduos e apresentar uma "defesa da moral e dos bons costumes". E o quinto capítulo analisa a maneira pela qual a incorporação de sentimentos como o civismo e o patriotismo serviam ao controle da conduta das pessoas ao mesmo tempo em que a moralização auxiliava na própria construção da representação do "Estado-nação". 


\section{DO CONTROLE DAS PAIXÕES À MAESTRIA DE SI: UM ESTUDO ACERCA DAS PRÁTICAS E DAS REPRESENTAÇõES DE MORALIZAÇÃO NA ESCOLA PÚBLICA PAULISTA \\ (1948 - 1978)}

\section{INTRODUÇÃo}

O exercício de entender como estiveram presentes as práticas e as representações de moralização na escola pública paulista poderia ter sido feito de várias formas e compreendendo diversos períodos da história da educação brasileira. A presente investigação é realizada sobre um período que compreende a democratização das oportunidades de educação pública e que mudou profundamente as configurações da estrutura do ensino, que passou a contar com muitos professores, das mais diversas origens sociais e formações profissionais e que também trouxe a heterogeneidade para dentro da sala de aula, com o ingresso de uma clientela escolar distinta da que anteriormente freqüentava os bancos escolares, o que repercutiu não apenas na configuração do espaço escolar como também no exercício do trabalho docente, alterando o modelo de escola que era mantido desde a época republicana. O presente estudo não versa apenas sobre a educação moral dos indivíduos, tal como foi pensada pelo sociólogo francês Émile Durkheim (2008), nem tampouco se trata de uma investigação acerca da disciplina educação moral e cívica, apesar da obrigatoriedade da mesma ter sido instituída durante o governo militar, momento compreendido no interior dos marcos temporais utilizados para o desenvolvimento deste trabalho. O emprego do termo "moralização" utilizado aqui é entendido como a moral que visa a ser praticada, inserida no comportamento das pessoas, daí a opção por uma investigação das práticas e das representações da mesma. Este estudo não foi construído a partir de um referencial teórico rigidamente demarcado pois, conforme a pesquisa evoluía, foi possível perceber que diversos autores poderiam auxiliar na compreensão da questão investigada, o que se deve à própria análise da fontes já que à medida em que os discursos que pretendiam moralizar, em um mesmo período e em muitos 
momentos originários de um mesmo autor, provinham de origens distintas e por vezes contraditórias - como é o caso, por exemplo, da associação entre o religioso e o laico. A expressão empregada no título, "Do controle das paixões à maestria de si”, é fruto da reunião de termos utilizados pelos autores dos artigos das revistas pedagógicas e dos manuais de didática, quando eles tratavam de questões relativas à moralização dos indivíduos durante o período investigado. A forma como as palavras foram arranjadas para dar nome a esta tese visa a evidenciar um movimento que foi percebido no decorrer do estudo. Para transformar a moral em educação e a educação moral em moralização, ou seja, para que a moral fosse incorporada pelas pessoas, comandasse os seus atos e fosse transformada em práticas, era necessário que os indivíduos inicialmente aprendessem a controlar e a inibir as suas paixões e os seus desejos, associados àquilo que há de primitivo e selvagem nos seres humanos, para então chegarem à maestria de si, associada à civilidade e à imposição de um padrão de conduta no espaço social, e ao autocontrole. É curioso observar também que este mesmo movimento, que deveria ser incorporado pelos agentes durante o processo de conformação moral ao longo de sua escolarização, coincide com uma mudança no discurso, no próprio campo educacional, acerca da conduta do comportamento dos alunos. Enquanto os textos que traziam a opinião de autores partidários de uma visão mais tradicional da educação defendiam que a disciplina deveria ser conquistada mediante o uso de castigos físicos e de humilhações públicas, aqueles que defendiam os ideais da educação renovada, trazendo a influência do movimento da Escola Nova, defendiam que os alunos deveriam aprender a utilizar a liberdade e a autogovernar-se, transformando a punição de algo externo para algo interno, que acionaria um tipo de controle sobre o próprio comportamento. Enquanto o primeiro movimento evidencia o controle explícito de uma pessoa ou uma instituição à conduta dos indivíduos, o segundo opera para que o próprio agente incorpore as regras morais e conduza a si próprio. Além disso, as próprias práticas e representações de moralização foram transformadas à medida que a configuração do modelo escolar mudava, em função da expansão do ensino e da intensa ocupação do espaço escolar. Se, até os anos de 1940, era possível que os professores exercessem um controle maior acerca do comportamento dos alunos, cuja origem sócio-econômica em ambos os casos não era tão diferente, mediante um contato mais próximo entre si, com a expansão das oportunidades de educação pública e a complexidade tomada pela organização do sistema de ensino, foi necessário que as estratégias de controle assim como as estratégias de poder, 
passassem por um avanço tecnológico, cuja atenção voltava-se não apenas ao corpo, mas principalmente à alma das pessoas.

Teobaldo Miranda Santos em 1962 editou pela terceira vez o manual pedagógico intitulado Curso de Psicologia e Pedagogia: Manual do Professor Primário. Neste livro, no capítulo 1, denominado "O Professor Primário", o autor dedica-se a escrever acerca da aparência física dos professores, considerada como uma de suas principais qualidades: "Na educação, dizia Dupanloup ${ }^{1}$, a palavra é um grande instrumento espiritual e moral, é o nobre órgão do espírito e do coração que se dirige à alma, penetra-a, ilumina-a, condu-la, cativa-a, domina-a. É a alavanca que tudo remove. Mas, para que as qualidades produzam todo o seu efeito é necessário que a elas correspondam uma certa dignidade exterior do mestre, manifestada pela correção e modéstia do vestuário, pela simplicidade e delicadeza das maneiras e pela serenidade e distinção das atitudes. O porte do mestre tem de ser severo e simples, evitando as manias ridículas ou os gestos desordenados. As atitudes sem compostura, a afetação solene e o gesto presunçoso estão dissociados do bom tom” (p. 21 grifos meus). Referências como esta são recorrentes nos manuais pedagógicos editados durante o período investigado e permitem admitir que, para ensinar bem, era desejável que os professores apresentassem uma determinada postura, associada à decência e às virtudes. Os textos apresentados tanto naqueles livros quanto nas revistas pedagógicas evidenciam um discurso sobre a prática, visando impor um padrão de comportamento, uma norma. Tal imposição acaba por contribuir para a construção da identidade docente. É desta forma que a análise acerca de práticas e representações torna-se fértil para a realização do presente estudo.

Ao discutir a identidade e a representação acerca da idéia de região, Pierre Bourdieu (2000) defende que na prática social, características como a língua, o dialeto ou o sotaque, que associam a identidade dos indivíduos a lugares distintos, são objeto de representações mentais, ou seja: "de actos de percepção e de apreciação, de conhecimento e de reconhecimento em que os agentes investem os seus interesses e os seus pressupostos, e de representações objetais, em coisas (emblemas, bandeiras, insígnias, etc.) ou em actos, estratégias interessadas de manipulação simbólica que tem em vista determinar em

\footnotetext{
${ }^{1}$ Félix Dupanloup (1802-1878). Sacerdote francês. Seu interesse pela educação o levou a dedicarse à formação do clero. Publicou obras no campo da educação e estas lhe deram acesso à Academia Francesa, sendo membro da comissão que redigiu a lei sobre a liberdade de ensino.
} 
representação mental que os outros podem ter destas propriedades e dos seus portadores" (op. cit., p. 112), funcionando, desta forma, como poderes. Como tais, as propriedades simbólicas podem ser utilizadas em função dos interesses materiais e também simbólicos do seu portador. Ao classificar a região e suas características, o geógrafo, em afirmar uma "verdade" que tem força de lei, configura um ato de conhecimento. É com seu poder simbólico que ele produz a existência daquilo que anuncia. No processo de produção da identidade, seja ela profissional ou regional, o indivíduo busca a assimilação, a qual supõe um trabalho que possa fazer desaparecer os sinais originais, que lembram o estigma (no estilo de vida, no vestuário e na pronúncia). As representações correspondem assim tanto a "imagens mentais" quanto a "manifestações sociais", através das quais se estabelece "o sentido e o consenso sobre o sentido, em particular sobre a identidade e a unidade do grupo, que está na raiz da realidade da unidade e da identidade do grupo" (op. cit., p. 108). Acerca do conceito de representação, é possível estabelecer um diálogo entre as idéias apresentadas por Pierre Bourdieu (1996, 2000) e por Roger Chartier (1990, 1991), por conceberem o mundo social de maneira semelhante. De acordo com Chartier, através da noção de representação é possível compreender as diversas relações que os indivíduos estabelecem com o mundo social e identificar a forma como em momentos e lugares distintos uma mesma realidade social é construída e pensada. As operações de classificação produzem configurações múltiplas através das quais a realidade é percebida e representada. Os signos, por sua vez, visam a fazer reconhecer uma identidade social, a exibir uma maneira de ser no mundo, significando simbolicamente uma posição. Através de formas institucionalizadas, os representantes encarnam de modo visível a coerência de uma comunidade, a força de uma identidade ou a permanência de um poder. Divisões e delimitações organizam a apreensão do mundo social como categorias fundamentais de percepção e apreciação do real. A propósito dessa questão, o autor apresenta a seguinte consideração: "variáveis consoantes às classes sociais ou os meios intelectuais são produzidas pelas disposições estáveis e partilhadas, próprias do grupo. São estes esquemas intelectuais incorporados que criam as figuras às quais o presente pode adquirir sentido, o outro tornar-se inteligível e o espaço ser decifrado" (op. cit., 1990, p. 17). Desta forma, não há prática que não seja produzida pelas representações, e pelas lutas travadas em torno das mesmas. As representações são as matrizes dos discursos e das práticas, que adquirem existência a partir do momento que comandam atos. Através das representações os indivíduos dão sentido ao mundo que é o deles. Nessa perspectiva foram consideradas as práticas e as representações 
de moralização na escola pública paulista no período compreendido por esta investigação. O processo de formação por que passam os professores contribui para a construção de um habitus profissional legítimo, que produz práticas e representações, e é incorporado pelos agentes por meio dos processos escolarização. De acordo com Pierre Bourdieu (2000, 2005, 2006), o habitus pode ser entendido como um conjunto de disposições incorporadas que estão na origem da ação das pessoas. Considerando os sistemas de relações objetivas como realidades constituídas na história do indivíduo e do grupo, o autor considera que seja preciso elaborar uma teoria da prática, do modo de construção e geração das práticas, que é a condição da construção de uma ciência experimental da dialética da interioridade e da exterioridade (da interiorização da exterioridade e da exteriorização da interioridade). As estruturas são constitutivas de um tipo particular de meio ambiente e produzem habitus, definidas como estruturas estruturadas predispostas a funcionarem como tal, ou seja, princípio de geração de práticas e de representações. Assim, “(...) as práticas que o habitus produz enquanto princípio gerador de estratégias que permitem enfrentar situações imprevistas e incessantemente renovadas são determinadas pela antecipação implícita de suas consequiências, isto é, pelas condições passadas da produção do seu princípio produtivo, de tal maneira que tendem sempre a reproduzir estruturas objetivas cujo produto em última análise são”. (BOURDIEU, 2006, p. 164) O habitus do indivíduo também está associado às suas aspirações, às probabilidades de acesso ao ensino superior e à arte. Ele aciona um sentido de jogo no indivíduo que o orienta em sua prática, fazendo com que ele aja sem pensar. $\mathrm{O}$ habitus diz respeito a um modo de ser e de estar no mundo, contando com um corpo de sabedoria semiformalizada, ditados, lugares-comuns, "preceitos éticos ('isso não é para nós') e, mais profundamente, os princípios inconscientes do ethos, disposição geral e transponível que, sendo o produto de toda uma aprendizagem dominada por um tipo determinado de regularidades objectivas, determina os comportamentos 'razoáveis' ou 'não razoáveis' (as 'loucuras') para qualquer agente submetido a tais regularidades”. (op. cit., p. 165) As práticas são fruto das primeiras experiências do indivíduo na medida em que são as estruturas características de um tipo determinado de condições de existência, que, "através da necessidade econômica e social que fazem pesar sobre o universo relativamente autônomo das relações familiares, ou melhor, através das manifestações propriamente familiares dessa necessidade externa (interditos, preocupações, lições de moral, conflitos, gostos, etc), produzem as estruturas do habitus, as quais estão por sua vez no princípio da percepção e da apreciação de toda a experiência ulterior". (op. cit., p. 166) De acordo com a 
geração ou a classe social, algumas práticas para uns são consideradas naturais. E para outros impensáveis. Talvez seja mesmo o caso do habitus professoral, que marca a pessoa que se torna professora e aciona um certo modo de agir, ser, estar e se comportar muito particular.

Há uma orquestração dos habitus de pessoas de um mesmo grupo social, que faz com que seja possível entender as atitudes e as intenções de seus pares. Cada agente é, ao mesmo tempo, produtor e reprodutor de sentido objetivo, porque suas ações e sua obras são produto de um modus operandi. O habitus é a mediação universalizante que faz com que as práticas sem razão explícita e sem intenção significante de um agente singular sejam sensatas, razoáveis e orquestradas. Ele compreende sistemas de disposições como uma competência lingüística e uma competência cultural. É a sua posição presente e passada a estrutura social que os indivíduos transportam consigo, sob a forma dos habitus que trazem como um vestuário e que, como o hábito, fazem o monge, ou seja, a pessoa social. Todas as disposições da pessoa são marcas da sua posição social e da distância social que trazem consigo diante dos outros, daqueles que ocupam outras posições. As pessoas observam o comportamento das outras para que se aproximem e também para manter distância. Mantendo-se cada um em seu lugar. Sendo produto da história, o habitus produz práticas, individuais e coletivas, e portanto história, em conformidade com os esquemas engendrados por essa mesma história."O habitus é o produto de um trabalho de inculcação e de apropriação necessário para que esses produtos da história coletiva que são as estruturas objetivas (da língua, da economia, etc) consigam reproduzir-se, sob a forma de disposições duradouras, em todos os organismos submetidos aos mesmos condicionamentos e colocados nas mesmas condições materiais de existência" (op. cit. p. 182).

Os habitus dos membros de um mesmo grupo são homólogos porque são produto da interiorização das mesmas estruturas fundamentais. Há uma identidade nos seus esquemas de percepção, que leva à homologia das visões de mundo. $\mathrm{O}$ habitus adquirido na família reside na estruturação das experiências escolares (em particular da recepção e assimilação da mensagem pedagógica), estando o habitus transformado pela ação escolar, ela própria diversificada no princípio da estruturação de todas as experiências anteriores (mensagens produzidas pela indústria cultural ou experiência profissionais), e assim por diante, de reestruturação em reestruturação. O trabalho pedagógico é exercido através de um 
ambiente simbolicamente estruturado, que exerce uma ação pedagógica anônima e difusa. O essencial do modus operandi que define o domínio prático transmite-se no estado prático, sem que chegue ao nível do discurso. Não se trata de imitar modelos, mas sim as ações dos outros. A hexis corporal, enquanto esquema postural, ao mesmo tempo singular e sistemático, traz consigo um sistema de técnicas do corpo abrangendo uma multiplicidade de significações e de valores sociais. As crianças incorporam todos esses gestos e posturas dos adultos. Tais esquemas são transmitidos de prática à prática, sem que haja uma explicitação. Contudo, muitas vezes os valores transmitidos pela escola divergem daqueles difundidos pela família, por conta dos contrastes advindos de sua origem sócioeconômica, como ocorreu durante o período de expansão pública brasileira. Desta forma, os professores são levados a incorporar uma maneira de portar-se e de agir, práticas estas que são fruto de suas representações mentais referentes à profissão. Contudo, não são apenas práticas acerca da conduta desejável a si próprios que os docentes incorporam, mas também representações acerca do aluno ideal. Assim, a relação professor-aluno passa por uma certa simbiose durante o cotidiano escolar e a escola exerce a ação de imposição e de inculcação de uma identidade legítima. As representações acerca do que vem a ser um aluno e do que vem a ser um professor acabam sendo reproduzidas nas instituições escolares e na sociedade através de seus próprios agentes, que acabam adequando-se às mesmas mediante suas práticas e, assim, atuando também na produção da crença na existência de comportamentos desejáveis à formação dos indivíduos.

Segundo Gilson Pereira (2001), o habitus dos professores seria marcado pela inércia, pois tenderia a manter as suas disposições, mesmo se as condições sociais que o geraram mudaram ou desapareceram. Em ambos os periódicos educacionais, de natureza bastante distinta, tomados como fontes para o desenvolvimento desta tese, a Revista Brasileira de Estudos Pedagógicos (RBEP), apresentando um caráter mais acadêmico e pretendendo-se científica, e a Revista do Professor (RP), produzida por uma associação docente, mesmo trazendo textos escritos por pessoas que ocupavam diferentes posições no campo educacional - pesquisadores e professores universitários no caso da RBEP e professores primários, diretores de escola e inspetores escolares do caso da $\mathbf{R E}$ - são reiterados os valores originários da profissão docente. Durante o exame dos artigos encontrados nos dois periódicos, que traziam referências à moralização dos agentes da escola, foi possível perceber que os autores desses textos mobilizaram constantemente, ao longo de todo o 
período estudado, representações como, por exemplo, a do "professor sacerdote" e a da "professora mãe". Foi possível perceber neste estudo que a representação do trabalho docente foi impregnada por um discurso ideológico que enxergava as professoras primárias como missionárias e que contribuiu também para a inércia de seu habitus.

A idéia da forma escolar ajuda a compreender de que maneira a escola apropria-se da idéia de "moral" e a transforma em prática de moralização. Constituída historicamente, a aparição e o desenvolvimento da forma escolar podem ser colocados em relação ao desenvolvimento de uma forma política singular que atende pelo nome de Estado. De acordo com Bernard Lahire, Daniel Thin e Guy Vincent (2001), a invenção da forma escolar, na França, situa-se nos séculos XVI e XVII. Trata-se de uma forma inédita de relação social, entre um "mestre" e um "aluno", relação que hoje chamamos de "pedagógica". Antes disso, aprender se fazia por ver fazer e ouvir dizer, aprender não era diferente de fazer. Isso ocorria com as próprias famílias e dentro das próprias casas. A autonomia da relação pedagógica instaura um lugar específico onde se realizam as atividades sociais: a escola. Nesse momento foram criadas então escolas de um tipo novo, destinadas a todas as crianças, inclusive às mais pobres, no entanto, para exercerem os ofícios elas não precisavam dos saberes transmitidos pela escola. Para além do temor das classes perigosas, a constituição da forma escolar acompanhou a instauração de uma nova ordem urbana, uma redefinição dos poderes civis e religiosos: "colocar todas as crianças, até mesmo as pobres, nas escolas é um empreendimento de ordem pública. Trata-se de obter a submissão, a obediência, ou uma nova forma de sujeição, além disso, o aluno aprende a ler por meio de 'Civilidades' e não nos textos sagrados (ou nos documentos manuscritos que, porventura, estivessem em poder de sua família). O que a criança aprende a ler em 'Civilidades', ao copiar grande número de tipos de escrita diante de um mestre que, medida do possível, nunca deve falar? "Ele aprende a obedecer a determinadas regras - maneira de comer, de assoar o nariz, de escrever, etc - conforme regras que são constitutivas da ordem escolar, que se impõem a todos (a começar pelo próprio silêncio dos mestres)" (op. cit., p. 14). A ordem escolar, citada pelos autores, existe a partir do momento em que as crianças precisam aprender a se comportar dentro do espaço escolar, o que torna possível ensinar muitos alunos ao mesmo tempo. Diferente das escolas confessionais, esses professores que não pregam mostram o que é a relação pedagógica: uma submissão do mestre e dos alunos a regras impessoais. Num espaço e num tempo 
totalmente regulados, cada um submete sua atividade aos "princípios" ou regras que a regem. Os colégios dos jesuítas fizeram passar de uma comunidade de mestres e alunos ao governo severo dos alunos pelos mestres, do enunciado das condições de um estilo de vida a um regulamento de disciplina, fixando com rigor e detalhes cada ocupação do dia. A forma escolar, que também moraliza, controla os desejos e reprime a espontaneidade. Sua emergência se dá a partir de um conjunto coerente de traços: a constituição de um universo separado da infância, a importância de regras de aprendizagem, a organização racional do tempo, a multiplicação e a repetição de exercícios, cuja função consiste em aprender conforme as regras. Assim, para além de ensinar a ler, a escrever e a contar, a sociabilidade exercitada na escola ensinaria também civilidade e visaria à formação do cidadão respeitoso e obediente, conhecedor de seus direitos e, sobretudo, de seus deveres. Ligações profundas unem a escola e a cultura escrita num todo sócio-histórico: a constituição do Estado moderno, instituição de viria a se impor a todos; a progressiva autonomização de campos de práticas heterogêneas; a generalização da alfabetização e da forma escolar. A escola e a "pedagogização" das relações sociais de aprendizagem estão ligadas à constituição de saberes escriturais formalizados, relacionados tanto ao que é ensinado quanto à maneira de ensinar, tanto à prática dos alunos quanto à prática dos professores. Trata-se de fazer interiorizar, pelos alunos, determinados saberes que conquistaram coerência pela escrita (mediante um exercício de classificação, divisão e comparação) e de fazer reviver, por um trabalho específico, a prática pedagógica, os resultados do trabalho passado.

Com a separação entre o Estado e a Igreja, a confiança para a manutenção da ordem foi depositada nas escolas, segundo certos procedimentos e objetivando o desenvolvimento de determinado espírito: as crianças deveriam se tornar adultos preparados para o Estado, afeiçoados ao seu país, submissos, não pelo temor mas pela razão, à autoridade, solidários com seus concidadãos, acostumados a reconhecer e respeitar a justiça. A forma escolar, com seu modo de socialização específico, ao mesmo tempo em que transmite saberes e conhecimentos, está fundamentalmente ligada a formas de exercício do poder. De acordo com Lahire, Thin e Vincent, isto não se aplica apenas em relação à escola, pois qualquer modo de socialização, qualquer forma de relação social, implica ao mesmo tempo na apropriação de saberes (constituídos ou não como tais, isto é, como saberes objetivados, explícitos, sistematizados, codificados) e na aprendizagem de relações de poder: saber 
quem manda, quem obedece, como se manda e como se obedece. A escola é também o lugar da aprendizagem de formas de exercício do poder: em sua hierarquia, o superior detém o poder, contudo, não se obedece a uma pessoa, mas a regulamentos impessoais. Assim como os alunos, os professores também têm normas a seguir, mostrando-se a cada momento como exemplos daqueles que cumprem as regras. Submetidos a um certo governo impessoal derivado das formas de sociabilidade constituídas a partir do Estado moderno, todos devem ter uma chance de se fazer obedecer. A submissão às regras deve ser desejada porque é compreendida racionalmente. Nesta perspectiva, o adestramento é rejeitado: a disciplina não deve ser suportada, mas sim compreendida e aceita: "ao compreender as regras, o aluno se apropria delas por si mesmo e pratica uma espécie de autodisciplina, um 'self-governement'. A razão é, portanto, o poder sobre si mesmo que substitui o poder de um outro, exercido a partir do interior" (op. cit., p. 33). Esta idéia do poder sobre si exercido a partir do interior é especialmente fértil para a compreensão das práticas e das representações de moralização na escola pública paulista durante o período investigado. Isto porque, no momento de expansão das oportunidades de educação pública, as portas das escolas se abriram para as massas. Além da diversidade em relação à clientela que passou a ocupar o espaço escolar, a origem social dos professores primários também mudou. Pensar a questão mediante a ótica do autogoverno permite entender melhor o quanto, na dificuldade de governar as massas e gerir a diversidade no interior das instituições escolares durante a democratização, foi importante levar cada a governar a si próprio: não apenas nas escolas primárias, mas também nos cursos de formação de professores, nas escolas normais e depois nos cursos de magistério. Conformar moralmente as professoras primárias a tal ponto que elas fossem consideradas exemplos que deveriam ser seguidos pelos alunos e torná-las tão amáveis e ternas até que tivessem a sua identidade confundida com a da figura materna parecem ter consistido em estratégias que visavam não apenas à formação das crianças mas que também tinham por objetivo controlar o trabalho docente. Desta forma, o autogoverno conquistado mediante o processo de conformação moral dos indivíduos, como será demonstrado ao longo deste trabalho, parece ter sido um elemento necessário à própria existência da democratização das oportunidades de educação pública. Submeter às crianças atividades organizadas, de modo a regular o seu tempo, garantindo a sua ocupação incessante, poderia enquadrá-las e vigiá-las, mas também geraria disposições em relação à regularidade. Submeter o desenvolvimento da vida dos indivíduos a uma divisão em sequiências temporais previstas antecipadamente e levá-los a "fazer as coisas na hora certa" 
seria o tipo de comportamento propício a adquirir a forma de uma moralidade que é a do dever. As ações organizadas visariam não somente a vigiá-los, mas também a levá-los a adquirir hábitos de vida regular, assiduidade e pontualidade. As práticas escolares, ao mesmo tempo em que educavam, moralizavam, inseriam a moral no comportamento das pessoas, transformando os valores em atitudes. Assim, seria indissociável formar o corpo, o conhecimento e a moral. A imposição de regras, para ser de fato incorporada pelas pessoas e transformada em disposições que levariam à ação, não se daria a partir do exterior, de maneira mecânica, mas sim por sua justificação e compreensão, ou seja, por uma adesão refletida.

Além do modelo de escola, foi possível perceber que também foram sendo construídas, ao longo do período estudado, representações acerca de "modelos" de professores e de alunos tidos pela organização dos sistemas de ensino como ideais. O autogoverno poderia consistir não apenas numa resposta para as necessidades deste modelo de escola que estava sendo configurado na época, como também poderia ser ele próprio uma condição para a existência deste. Além disso, as condições históricas do período, marcado pela expansão urbana e pelo desenvolvimento industrial, exigiam mão-de-obra minimamente qualificada e que cuidasse de si própria. A escolha do ano de 1948 como marco inicial para o presente estudo deve-se ao ano de início da "Campanha de Defesa da Escola Pública". Trata-se um movimento cívico importante na história da escola pública brasileira e que culminou, em 1961, com a promulgação da LDB n⿳0.024. Em 1948 foi iniciada a campanha, quando o então Ministro da Educação Clemente Mariani enviou à Câmara Federal o primeiro anteprojeto de uma lei de diretrizes e bases da educação nacional, conforme estava previsto na Constituição Federal de 1946. O anteprojeto havia sido elaborado por uma comissão de intelectuais prestigiados no campo educacional e teve como relator Almeida Júnior, então professor da Faculdade de Direito da USP. Durante a sua tramitação, numa primeira etapa, o anteprojeto foi discutido principalmente quanto ao seu propósito descentralizador na questão da organização dos sistemas estaduais de ensino (BARROS, 1960). Segundo José Mário Pires Azanha (1999), o texto aprovado e transformado na Lei 4.024, em 1961, foi um retrocesso com relação ao anteprojeto original. Isso porque o Deputado Carlos Lacerda havia apresentado dois substitutivos, um em novembro de 1958 e outro em janeiro de 1959, que mudaram o teor das discussões sobre o assunto. Para Lacerda, tratava-se de um embate entre aqueles que defendiam - como ele 
próprio - "o direito inalienável e imprescritível da família" na escolha da educação de seus filhos, e aqueles que lutavam pelo monopólio do Estado em matéria de educação. Segundo Roque Spencer Maciel de Barros (1960), o projeto de Diretrizes e Bases da Educação Nacional tomou a tese da "liberdade de ensino" no sentido de permitir a abertura indiscriminada de escolas pelos setores privados. Concebida desta forma, tal tese compreendia o abandono, pelo Estado, de sua função educadora e estava relacionada com a doutrina da livre-concorrência - com os princípios do liberalismo econômico. De acordo com o autor, no momento em que se concebe essa noção de liberdade de ensino, em termos de livre concorrência e abstenção estatal, o seu alcance e a sua significação tornam-se limitados e restritos e, além disso, não seria possível submeter aos interesses privados a formação de cidadãos livres. Era então reiniciada, novamente no país, uma disputa entre os interesses confessionais e privados em educação e a visão republicana da escola democrática, laica e gratuita. Desta maneira surgiu a referida campanha, que envolveu estudantes, professores e sindicatos, sob a liderança, em São Paulo, da antiga Faculdade de Filosofia, Ciências e Letras da Universidade de São Paulo.

O período compreendido por este estudo encerra-se em 1978, quando mudanças no comportamento dos professores ganharam visibilidade a partir do momento em que os mesmos aderiram a uma greve, ainda no regime militar, à revelia das entidades que os representavam, como a Associação dos Professores do Ensino Oficial do Estado de São Paulo (APEOESP) e o Centro do Professorado Paulista (CPP). As fontes escolhidas, os manuais de didática e metodologia do ensino, as revistas pedagógicas e a legislação vigente no período, permitiram conhecer melhor os discursos veiculados, as normas e a obrigatoriedade referente a práticas e a condutas na escola assim como as orientações dadas aos professorandos e depois aos professores sobre a maneira como deveria ser realizado o trabalho docente, visando a oferecer a formação considerada "adequada" aos alunos. O estudo também buscou considerar as fontes de acordo com as condições de sua produção. Ao longo do exame das mesmas, foi possível perceber que as práticas de moralização eram diversas e a sua justificativa era fundamentada mediante variados discursos. Contudo, esses discursos, obedeciam a três eixos principais: psicológico, religioso e cívico. Portanto, o texto é divido em três partes principais por obedecer a uma escolha: a de respeitar as principais evidências que indicam que, para que as representações acerca da idéia de 
"moral" fossem transformadas em práticas nas escolas, era necessário evocar um discurso que é legitimado pela idéia de autocontrole, de Deus e de nação.

Ao longo de toda a história da profissão docente no Brasil, a moral esteve associada à imagem e ao trabalho dos professores. No século XVII, "a educação civil e moral do povo eram nenhumas, a da classe dos nobres cidadãos quase nula, e tudo se reduzia a algumas práticas religiosas, meramente externas, e a poucas escolas elementares regidas pelos jesuítas", , estes então começaram a praticar a instrução civil e moral. Em 1874, "Moral, Doutrina Cristã e Pedagogia" seria uma das disciplinas do curso normal. No decorrer do século XIX, ainda no período imperial, para que os professores obtivessem o direito oficial de lecionar em escolas, eles precisavam passar por uma prova que avaliava se eles sabiam ler, escrever, contar, rudimentos de religião e também quais eram as suas qualidades morais, conhecidas na época como "boa morigeração". Tais qualidades poderiam ser atestadas por meio de cartas de recomendação escritas pelo padre da paróquia. Durante o estudo que realizou acerca da história de uma professora que lecionou por trinta anos no período imperial, ao recuperar documentos relativos ao seu concurso, Maria Lucia Spedo Hilsdorf (1996) informou o seguinte acerca do concurso de Mestra Benedita para admissão na cadeira de mestra de meninas, em 1828: "O governo despachou também nesse mesmo dia, para que ela antes informasse se vivia com 'honestidade e bom comportamento público'. O 'reconhecimento' de Benedita foi feito em documento de 'pública forma' do Geral de Fora da cidade, por 3 testemunhas, entre elas o capitão Manoel Coelho Neto, 'de 45 anos, solteiro, morador de São Paulo, ofício de escrivão da procuradoria da comarca, [que] jura pelos Evangelhos que tem amizade na casa da justificante, é comportada, honesta e de costumes louváveis e tem capacidade para exercer o magistério" (op. cit., p. 96). A citação acima é bastante ilustrativa da relação entre a docência e a religião, que permeia inclusive os documentos oficiais e cristaliza-se pelo tempo através das práticas escolares. Exercido pelos jesuítas como uma missão, o ofício de ensinar ganhou, ao longo do século XIX, também o sentido de apostolado e profissionalizou-se. É a partir desta ambigüidade que se configura a profissão docente no Brasil. Contudo, no exercício de sua função, os valores originários da docência são visivelmente mais corporificados nos modos de ser e no

\footnotetext{
2 VIVEIROS, Jerônimo José de. "Apontamentos para a história da instrução pública e particular do Maranhão" RBEP, n 45, jan./mar. 1952, p. 29 - 83.
} 
trabalho das professoras (mulheres) do que dos professores (homens). Em meados do século XIX, com a migração dos homens para setores mais lucrativos financeiramente e de maior prestígio social, o magistério primário aos poucos foi aberto à participação feminina. Eliane Teixeira Lopes (1991), acerca deste processo de feminização do magistério, defende que "é a partir de um trabalho missionário religioso de apostolado e missão da palavra e da essência divina (que como se sabe ocupa o lugar daquilo que é concebido como sem falta, sem fissura, sem ambigüidade), que as mulheres entram no magistério" (op. cit., p. 38).

Durante o período republicano havia, por parte das autoridades públicas, a necessidade de impor normas "civilizadas" nas relações de gênero e de conter a sexualidade dentro das famílias "higienizadas", o que seria parte de um processo mais extenso de controle social nesta época. Segundo Sueann Caulfield (2000), que realizou um estudo acerca da moralidade feminina entre os anos 1918 e 1940 no Rio de Janeiro, os juristas, por exemplo, viam a família como a base da nação e um espaço social que produziria uma força de trabalho dedicada, honesta e disciplinada. A propósito do clima ou da miscigenação racial influenciar o comportamento moral dos brasileiros, o jurista Viveiros de Castro, ao observar "a suposta propensão de seus compatriotas à sensualidade e ao amor e ao julgar que havia um aumento da imoralidade no Rio de Janeiro, esboçou uma questão-chave que achava imprescindível pesquisar: seria isso conseqüência da 'mera exuberância do instinto sexual' provocada pelo clima tropical, da educação rudimentar do povo ou um legado cultural da escravidão? Ou seria a população brasileira já degenerada por causa da miscigenação racial? A resposta, para ele, devia conduzir a prática e a ciência jurídicas" (op. cit., p. 87). Segundo a autora, Cesare Lombroso (1835-1909), médico italiano adepto do pensamento positivista, Herbert Spencer (1820-1903), filósofo inglês e adepto do positivismo, Richard von Krafft-Ebing (1840-1902), psiquiatra alemão que realizou estudos sobre o comportamento sexual e introduziu em sua obra conceitos como "sadismo", "masoquismo" e "fetichismo", e outros cientistas europeus, ajudaram a fundamentar um discurso que defendia que o pudor havia atingido maior intensidade nas mulheres como uma forma de proteção contra os instintos sexuais violentos dos homens primitivos. Mas teria sido a Igreja Católica, mas especialmente por meio dos escritos de Santo Agostinho sobre a "santidade da virgindade", que teria difundido os princípios do pudor por todo o mundo civilizado. O pudor formaria a base da moralidade individual, que por sua vez formaria a moralidade pública, e seria "a garantia de toda civilização" (op. cit., p. 88). Era, 
portanto, do interesse do Estado promover a moral cristã, evitando a sexualidade descontrolada, que representaria um retrocesso "ao estado selvagem". Segundo Caulfield, para seguir esse modelo, o Brasil precisaria livrar-se da reputação de terra da fantasia tropical habitada por nativos primitivos.

Além de relacionar-se ao pudor e ao controle da sexualidade, a moral reflete uma série de costumes e normas relacionados à vida em coletividade, como, por exemplo, o civismo, a caridade, o respeito ao outro, que dependem da formação da vontade do indivíduo para que se concretizem. As normas morais seriam incorporadas pelas pessoas através de um movimento que levaria das representações e dos discursos às práticas. No caso das crianças, os sermões ou os contos que trouxerem "a moral da história", não seriam garantia para determinada ação moral. Se os discursos morais, ao definirem os ideais de Bem e de Mal, levariam as pessoas a agir de acordo com os mesmos e, nesta perspectiva, a prática seria decorrente da teoria, daí a importância de entender de onde vem tais discursos que legitimam as regras morais e as autorizam a reger o comportamento humano em determinada época e em certo período da história. A teoria acerca da moral, por se tratar de um conjunto de normas que regulam a conduta, seria ela própria uma espécie de projeção abstrata da moral praticada. Segundo Yves de La Taille (1994), no prefácio à edição brasileira do livro O juízo moral, de Jean Piaget, "as teorias não nascem da reflexão pura e isolada de um pensador; na verdade, este pensa a prática moral já estabelecida, e lhe confere coerência (até onde consegue) através de princípios. E se esses princípios influem no comportamento dos homens, é que, de certa forma, estes já agiam de acordo com aqueles. Em resumo: primeiro está a ação, depois a tomada de consciência desta (abstração), que, aliás, pode muito bem ser crítica, mas que tem necessariamente por base a prática vigente." (p. 11) La Taille descreve o ponto de vista de Piaget, tanto para as dimensões históricas quanto psicológicas da moral, que a estudou como uma ciência dos costumes. No processo de conformação moral, seriam as relações de coação que levariam à incorporação de um pensamento moral que associaria o "Bem" às ordens dadas pelas autoridades - entre as quais estariam os pais, os professores ou os padres, por exemplo - e as relações de cooperação, implicando no respeito mútuo, levariam a uma moral autônoma, dependente da assimilação dos motivos das regras aceitas. De acordo com os estudos de Piaget, tal fato estaria evidente no desenvolvimento das crianças, e incorporado entre os adultos. 
$\mathrm{Na}$ fase do desenvolvimento em que estão as crianças no período em que freqüentam a escola primária, em torno dos sete aos dez anos de idade, o processo de conformação moral seria privilegiado pela coação exercida pela autoridade em questão. No caso do espaço escolar, esta autoridade seria representada pelos professores e, em se tratando do período estudado (1948 - 1978), nos referimos especialmente às professoras primárias. Nesta perspectiva, se elas seriam as responsáveis por ditar o "Bem", promover a transmissão dos valores morais e conduzir a conduta das crianças, seria preciso que elas próprias sofressem um rigoroso processo de conformação moral, que faria delas não apenas exemplos de conduta, como também autoridades dignas de respeito e admiração. Desta forma, o processo de conformação moral a que se refere este trabalho é entendido como uma espécie de simbiose na qual a relação professor-aluno é não apenas o meio como também a condição para a sua existência: como se passasse por uma correia de transmissão, os valores morais seriam transmitidos das professoras aos alunos, que deveriam refletir os gestos e a conduta daquelas que, por sua vez, precisariam cuidar cada vez mais da sua própria apresentação e exposição para legitimar a posição ocupada. Se a incorporação da moralidade pelas crianças seria necessária para formar cidadãos úteis à Pátria, cristãos tementes a Deus ou indivíduos capazes de ter autocontrole suficiente para controlar os próprios impulsos, - todas as alternativas contribuindo para o bom governo e o convívio social - como será visto mais adiante, no caso das professoras primárias, com a passagem do tempo no exercício da profissão, as regras morais das quais elas eram as portadoras eram corporificadas em si próprias, tornando-as, com as palavras de Afro do Amaral Fontoura (1965), autor de manuais pedagógicos da época, "exemplos vivos" daquilo que proclamavam. Contudo, para que a educação moral de fato se efetivasse, refletindo no comportamento dos alunos, não era necessário que ela fosse apenas um "verniz" (palavra de uso comum na época utilizada por aqueles que criticavam a eficiência das escolas): ela deveria "exercitar-se de dentro para fora"3. Desta forma, tanto para a eficiência da conformação moral dos alunos quanto dos professores, a atenção seria voltada para a condução da sua própria subjetividade. Neste caso, o que estava em jogo era o controle da alma dos indivíduos. Se na vida social existem convenções que auxiliam na ordenação do comportamento moral dos indivíduos, nas escolas as crianças seriam preparadas para aceitá-

\footnotetext{
${ }^{3}$ FONTOURA, Afro do Amaral. Didática Geral 8 $8^{\text {a }}$ edição Rio de Janeiro: Aurora, 1965.
} 
las e para aprender a se comportar diante de tais convenções, condicionando o seu cotidiano através do controle da sua alma. Contudo, o comportamento das professoras e sua função de exemplo seriam fundamentais para que tal empreitada funcionasse.

Não há como pensar na moral inserida no sistema de ensino sem levar em consideração a sua importância na crença de que uma população bem educada e moralizada garantiria o bom funcionamento da vida social. Esta visão, bastante difundida na literatura pedagógica e nos discursos evocados no campo educacional, é inicialmente trazida pela influência do catolicismo e dos jesuítas na educação nacional, depois é fortalecida pelos ideais republicanos que tomam a educação como um dos pilares da organização nacional e em seguida ecoam a teoria do francês Émile Durkheim (2008), para quem: “quando as forças morais de uma coletividade permanecem desocupadas, quando elas não estão engajadas em alguma atividade a ser realizada, elas se desviam do seu sentido moral e passam a ser empregadas de maneira mórbida e nociva" (op. cit., p. 28-29). Para o autor, na sociedade moderna, o melhor lugar para a moralização seria mesmo a instituição escolar, devido à insuficiência moralizadora da família. Quando Durkheim trata da questão da moralização ele está ao mesmo tempo referindo-se à educação das pessoas e a sua reflexão emerge em um período no qual o sistema pedagógico francês, segundo ele, passava por uma crise. Se a escola estava falhando ao conformar moralmente os indivíduos, a moralidade pública seria imediatamente afetada, pois dependia daquela para manter-se. A escola era considerada por ele como a "fonte" da moralidade pública. Tal crise a qual se referiu teria origem na revolução pedagógica realizada na França durante a sua Terceira República, período compreendido entre os anos 1870 e 1940, quando a escola passou a oferecer uma moral puramente laica e todo o ensino primário e secundário foi reestruturado, visando integrar as diversas partes do país. Ora, se a moral então seria laica, isenta de qualquer influência religiosa, e a escola falhava em exercer a educação moral, de fato Durkheim tinha um grande problema, porque com a família também não era possível contar para conformar moralmente os seus filhos, já que a sociedade estava revestida pelo véu da promiscuidade, ameaçada pela imigração, por doenças como a sífilis e o alcoolismo, e lidava com a derrota da guerra franco-prussiana. Inserido nestas condições sociais, o autor dedicou mais de vinte anos da sua vida na tarefa da construção da ciência da moral, que corresponde às exigências de um ensino popular e infantil que incutiria nas crianças os elementos da moralidade, as normas e as regras para manutenção da vida coletiva 
(FERNANDES, 1994). Quando nos propomos a estudar as práticas de conformação dos indivíduos em determinada realidade social, é importante compreender quais são os principais responsáveis pela educação ministrada às crianças. Durkheim falava em educação como processo de socialização, com o fim de suscitar e desenvolver na criança certo número de estados físicos, intelectuais e morais. Para ele, a educação iria transformar a criança, considerada como um "ser associal", numa pessoa humana, num ser social. A cada geração, a sociedade se encontraria frente a uma 'tábula rasa'. Desta forma, seria preciso "que por meios rápidos e seguros ela sobreponha ao ser associal e egoísta que nasce, um outro capaz de adaptar-se à vida social e moral" (RP, 1961, p. 5), sugeria Joaquim Bernardes ${ }^{4}$, em artigo publicado na RP em 1961. A vida social, enquanto conjunto de crenças, costumes, instituições, idéias e linguagem, constituídos ao longo da história, seria perpetuada ao ser transmitida pelos mais velhos aos mais jovens. Para Durkheim, o homem que a educação realiza nos indivíduos não é o homem criado pela natureza, mas o homem que a sociedade deseja que ele seja, e ela o deseja conforme a demanda de sua economia interna.

Sífilis, alcoolismo e promiscuidade, que tanto preocupavam Durkheim na França do começo do século XX, também ameaçavam a moralidade da sociedade brasileira nos anos de 1960, como foi possível observar nos discursos veiculados nas fontes examinadas. Doenças associadas à iminência de mudanças na formação familiar tradicional por conta das transformações sociais que a sociedade enfrentava e da possível falência na hegemonia da Igreja católica colocavam em risco o futuro da nação diante da ameaça da delinqüência e da vadiagem. Além disso, a época é marcada por uma crise que abalava a moralidade pública tradicional devido a manifestações sócio-culturais e a protestos contra o endurecimento do governo. Neste momento também há uma revolução comportamental com o surgimento do feminismo, a revolução sexual e os movimentos estudantis e "hippies", ou de contracultura, contrários à Guerra Fria, que foram muito populares nos anos de 1960 nos EUA e ganharam força no Brasil nos anos de 1970, colocando em xeque os valores tradicionais da classe média e o governo militar. Nos anos de 1960 também há, usando as palavras de Thomas Skidmore (1982) a configuração de "uma nova ordem política" no Brasil: "pela primeira vez o Exército estava unido numa posição ideológica contra o populismo. Essa posição foi pela primeira vez manifesta em fevereiro de 1954

\footnotetext{
${ }^{4}$ BERNARDES, Joaquim M. “Conceituação sociológica da educação”, RP, Jul./Set., 1961, p. 4 - 5.
} 
quando o 'memorando dos coronéis' tinha sido uma solicitação velada da demissão de Goulart da pasta do Trabalho. Esse anti-populismo transformou-se, porém, no subseqüente ultimato dos generais que acarretou no suicídio de Vargas em agosto de 1954. Agora, mesmo os moderados pró-legalidade chegavam à conclusão de que não se podia confiar em que os políticos populistas perturbassem o delicado equilíbrio social em que repousava a democracia brasileira" (op. cit., p. 367). Segundo o autor, foi a aparente destruição deste equilíbrio que levou os militares a uma conspiração ofensiva, culminando no golpe de 1964 e deixando o Exército preparado para desencadear uma guerra civil caso a esquerda radical mobilizasse qualquer facção. Além disso, o processo de industrialização e de urbanização que prometia libertar o Brasil do subdesenvolvimento e que o país conheceu nos anos de 1950, marcado por um forte nacionalismo, havia se ampliado e fortalecido em três setores: o industrial, a classe operária urbana e a classe média urbana. Especialmente no Estado de São Paulo, "o notável crescimento econômico (...) havia amplamente demonstrado a capacidade industrial brasileira" (op. cit., p. 117). Contudo, os "anos dourados", como também foi chamado o governo de Juscelino Kubitschek (1956-1961), além do desenvolvimento econômico desencadearam o problema da dívida pública interna e da dívida externa e da inflação nos governos seguintes de Jânio Quadros e de João Goulart. Assim, uma forte instabilidade social e econômica abalava a sociedade brasileira nos anos de 1960 e amaeçava os valores morais já consolidados. Tulio Expedito Liporoni ${ }^{5}$, em artigo publicado na RP em 1964, ilustra bem o medo advindo da falta de ordem social. Rapazes delinqüentes, "levando uma vida desgovernada e desregrada, entraram no organismo social como um vírus pernicioso, deixando de lado qualquer princípio de moral ou de religião. (...) Muitos desses menores provinham de lares desfeitos e poucos deles recebiam qualquer espécie de ensino religioso. Esses pequenos vagabundos que perambulam pelas ruas na vadiagem, na mendicância e transformados em camelôs, vêm de lares anarquizados e são nesses lares que se fabricam os menores delinqüentes. (...) urge ação enérgica de apoio e fortalecimento da família, pois o lar sem autoridade paterna é um caminho certo para a delinquiência. É necessário que o menor cresça num meio sadio, para que se torne um cidadão útil à Pátria. Assim, num lar onde há pobreza, falta de disciplina, brutalidade, defeituosas relações entre os familiares, falência de religião, poderão surgir menores

\footnotetext{
${ }_{5}^{5}$ LIPORONI, Tulio Expedito. “Delinqüência infanto-juvenil”, RP, Mai./1964, p. 26.
} 
delinqüentes. Amparar o menor é assegurar o futuro da nação. (...) a luta contra a delinqüência infanto-juvenil é um trabalho médico, pedagógico, moralista e cristão". (p. 26 - grifos meus) Desta maneira, para formar o cidadão útil à Pátria, era necessário fortalecer a família e investir na religião. Em casa, seria preciso contar com a autoridade paterna e, na escola, com a autoridade dos professores. O trabalho contra a delinqüência, como disse o autor, seria "médico, pedagógico, moralista e cristão" e, de fato, no processo de moralização dos indivíduos, neste período da história da educação brasileira, não existiu à margem deles.

No Brasil, até o início do século XIX a educação das crianças era ministrada principalmente em casa ou na comunidade, fato denominado como socialização endógena ou socialização primária. A partir de então, a educação das crianças passou a ter um lugar próprio para acontecer: as escolas, que inicialmente eram chamadas como "escolas de primeiras letras" ou "escolas isoladas" e, posteriormente, surgiram os grupos escolares (FARIA FILHO, 1996; HILSDORF, 1996; SOUSA, 1996). A socialização realizada nestes casos é conhecida como exógena ou secundária, por ocorrer fora do ambiente familiar. Até meados do século XIX, como a sociedade precisava principalmente da cultura oral para a sua manutenção, a socialização primária, realizada no lar, era suficiente para garantir às pessoas o aprendizado de que precisavam para sobreviver, conviver umas com as outras, trabalhar e formar uma família. Com a organização dos Estados modernos e também da burocracia advinda dele, a cultura oral passou a dar lugar em importância à cultura escrita. Assim, a escolarização foi aos poucos se tornando cada vez mais necessária para a sobrevivência, o trabalho e a vida das pessoas. Isso porque os contratos e os documentos passaram a multiplicar-se e a necessidade de que as pessoas aprendessem a escrever para produzi-los, obedecê-los e assiná-los também. Desta forma, a escola passou a ser considerada a instituição que seria capaz de oferecer às pessoas os elementos de que necessitavam para manutenção da vida em sociedade, nela as pessoas aprenderiam a ler, a escrever e a contar. E também rudimentos de religião, necessários à doutrinação e conformação moral dos indivíduos. A escola também seria um lugar determinante para o desenvolvimento dos atos morais pelas crianças. Ao citar a pedagogia de Pestalozzi, defendendo a educação promovida pela prática, Oswaldo de Souza ${ }^{6}$, em artigo publicado na

\footnotetext{
${ }^{6}$ SOUZA, Oswaldo de. “A pedagogia de Pestalozzi”, RP, Jan./Mar., 1963, p. 27.
} 
RP em 1963, dizia que "a educação moral se realiza por completo na ação coletiva. A escola é uma potência social educadora". A educação doméstica e a educação escolar seriam a base da organização social, porque "elas formam, dão seu sentido, trabalho e senso econômico." (p. 27) Como ambiente coletivo, seria importante para que as crianças participassem das emoções e do sentimento do grupo. Os professores poderiam aproveitar todas as oportunidades para estimular o desenvolvimento do sentimento do altruísmo na escola, expressando-se no amor ao próximo, na piedade, na solidariedade, criando assim um ambiente favorável à moralidade.

Se no século XIX os tipos de educação ministrados eram múltiplos e diversos, no início do século XX começou a existir um sistema de ensino unificado, sistematizado, pretensamente laico, gratuito e obrigatório. Nesse momento o Estado encarregou-se da educação formal, substituindo a Igreja. O poder, nessa época conhecida como "moderna", tornou-se exclusividade do Estado, que legitimava a sua autoridade através de regras, da magnificência da arquitetura dos edifícios, do currículo formal e da organização dos sistemas e ensino. A legitimação do poder do Estado ocorre através da adoração aos símbolos pátrios - a bandeira, o hino, fazendo com que a interioridade de cada um seja voltada para uma abstração. Enfim, tal legitimidade é construída através de todos os objetos que possam dar visibilidade a algo que passa a ser fundamental, mas que é abstrato: a palavra, que passa da forma oral para a escrita (FARIA FILHO, 2000). Na história da educação brasileira é possível notar que ora a educação escolar oferecida à população esteve principalmente sob a responsabilidade da Igreja e ora esteve sob a responsabilidade do Estado. Contudo, as investigações historiográficas recentes, que se interrogam acerca das práticas e da cultura escolar e que tentam reconstituir o cotidiano da escola, mostram que, de fato, o modelo de escola não foi construído de maneira linear e muitas vezes o público e o privado conviveram juntos em um mesmo espaço, assim como o laico e o religioso, mediante disputas no campo educacional. Como a luta travada entre católicos e pioneiros. (CARVALHO, 1989; HILSDORF, 2003) A exemplo disso temos, ainda hoje, escolas públicas, laicas e gratuitas, que possuem símbolos religiosos, são denominadas com nomes de padres ou santos, possuem crucifixos pregados em suas paredes e têm coordenadores pedagógicos que iniciam reuniões com a leitura de um salmo. Mesmo assim, ao longo do exame de todas as fontes consultadas, foi bastante surpreendente notar o quanto o discurso religioso, especialmente católico, foi apropriado pelos discursos veiculados nos periódicos 
educacionais, pelos manuais pedagógicos e pelos textos legais visando à imposição de práticas e ao controle da conduta das pessoas. O governo militar (1964-1985), por exemplo, pautado pelos ideais positivistas, falou muitas vezes em "nome de Deus" para estabelecerse no poder, além, é claro, de contar com as práticas de censura, de tortura e do uso da força.

Assim, o texto que se segue busca tecer uma análise sócio-histórica da forma como as práticas e as representações de moralização exercidas na escola existiram em função das demandas que foram impostas a esta instituição diante do desenvolvimento social, das questões políticas que atravessaram o período e que trouxeram mudanças significativas tanto na organização do trabalho docente, quanto nas relações pedagógicas construídas no espaço escolar, e também na imagem dos professores e dos alunos e em sua visibilidade social. Se em 1884, como castigo, as crianças que não haviam sido suficientemente comportadas traziam na cintura um papel escrito "vadio, descuidado, desordeiro, comilão ou qualquer palavra que publicasse o vício, o defeito ou a culpa no educando"7, entre os anos de 1948 e 1978, o processo de moralização e de (com)formação das condutas tornouse mais sofisticado na forma, mas ainda pagava tributo à sua origem.

\footnotetext{
${ }^{7}$ HILDEBRAND, Armando. "Conferência”, RP, Out./Dez., 1961, p. 3 - 7. Conferência em comemoração ao cinqüentenário do ensino industrial.
} 


\section{OS MODOS DE PRODUÇÃO DO TRABALHO}

No esforço de escrever acerca dos modos de produção do trabalho, explicando a maneira como foi feito o projeto que deu origem à esta pesquisa e a forma como a mesma foi desenvolvida, busco reconstruir brevemente aspectos da história da minha vida acadêmica, com a intenção de indicar os caminhos que me levaram às escolhas que fiz. Ingressei no curso de Pedagogia na Faculdade de Educação da USP em 1999. Na ocasião, sabia que ao escolher cursar Pedagogia abria-se um leque de oportunidades de atuação profissional - como professora de educação infantil, como coordenadora pedagógica, como professora no curso de magistério (meses depois extinto), trabalhando na área de recursos humanos, etc. - das quais a definição de cada uma, para mim, não era muito clara. Logo no primeiro semestre, durante a disciplina Didática I, a professora Denice Barbara Catani nos apresentou, a mim e a todos os alunos da turma, então a oportunidade de realizarmos pesquisa ao longo da graduação, tratava-se da Iniciação Científica. Seguiram-se então meses de reuniões e depois conversas até que fosse possível escrever um projeto e circunscrever um objeto para o desenvolvimento do estudo. A professora realizava uma ampla investigação que comparava Brasil e Portugal no período de surgimento da "escola de massas". Uma das vertentes para investigação seria o conhecimento sobre os alunos: a disciplina, o material escolar, os uniformes. Os uniformes escolares me pareceram mais atraentes - ou instigantes - não só pela originalidade do tema, mas também por configurarse como um objeto de estudo até então inédito no país. Além disso, nasci e morei toda a minha vida, durante o período escolar, em Santos. O calor que fazia e faz até hoje nesta cidade jamais combinou com a helanca e com a malha utilizadas para a confecção dos uniformes que eu era obrigada a usar para freqüentar as aulas. Como o traje era realmente obrigatório, todas as tentativas que fiz para não utilizá-los fracassaram: desde conversas com a diretora da escola e com os professores - que eram bastante freqüentes, pois sempre estudei em escolas pequenas, montessorianas e alternativas, que tornavam muito próxima a relação entre a direção, os funcionários, o corpo docente e o corpo discente - até a troca de algumas peças do uniforme escolar por outras de cor semelhante, mas de um tecido que eu considerava mais razoável para suportar a temperatura. Assim, estudar os uniformes 
também seria uma maneira de compreender as razões pelas quais tais roupas foram instituídas no cotidiano das escolas e permaneciam até então, apesar das resistências.

A pesquisa realizada no âmbito da Iniciação Científica deu origem ao projeto de mestrado que buscava identificar as práticas de uso dos uniformes escolares no Estado de São Paulo no período de expansão da escola pública. Desde o início da pesquisa tive a impressão de que a obrigatoriedade material imposta pelo uso dos uniformes parecia servir mais à exclusão do que à inclusão da clientela mais pobre na escola. As evidências encontradas permitiram afirmar a minha hipótese, ou pelo menos foi assim que pude percebê-las. Em 2006, o trabalho desenvolvido no âmbito do mestrado deu origem à dissertação intitulada “Criança Calçada, Criança Sadia!”: Sobre os uniformes escolares no período de expansão da escola pública paulista (1950/1970) e dela derivou o projeto de doutorado, que foi iniciado no ano seguinte, tendo por objetivo investigar não apenas as práticas de moralização e de uniformização impostas aos alunos, mas também aos professores. Na ocasião, a ampliação da investigação visaria a explicar também os motivos históricos e sociais que se apresentaram aos professores, cujos indícios existem ainda hoje, influenciando a conduta, a postura e moldando o comportamento daqueles que pretendiam seguir a carreira docente, e que me levaram também a considerar uma maneira de vestir e me apresentar - de forma muito recatada e discreta - no momento em que me tornei professora. Em decorrência do desenvolvimento da pesquisa, entre março de 2009 e fevereiro de 2010, eu tive a oportunidade de realizar um estágio de doutorado sanduíche em Paris, também com bolsa de estudos concedida pelo Conselho Nacional de Desenvolvimento Científico e Tecnológico (CNPq). O estágio foi realizado junto ao Service d'Histoire de 1'Éducation (SHE) do Institut National de Recherche Pédagogique (INRP), sob orientação do Prof. Dr. Pierre Caspard. A oportunidade de realizar esse estágio no exterior e o encontro com os referenciais teóricos franceses foi fundamental para que eu pudesse redimensionar o projeto inicial do doutorado. Paradoxalmente, o afastamento da realidade brasileira permitiu que dela eu ficasse mais próxima. A questão da educação moral, amplamente discutida na França até os dias atuais e tida como a responsável pela reconstrução do Estado após a derrota do país na guerra franco-prussiana é motivo de orgulho para os franceses: laica, ela legitima um Estado cujo lema é liberdade, igualdade e fraternidade, e corporifica em seus cidadãos estes ideais. Ao mesmo tempo em que eu realizava leituras acerca da educação moral deste país e percebia o quanto era atribuída à 


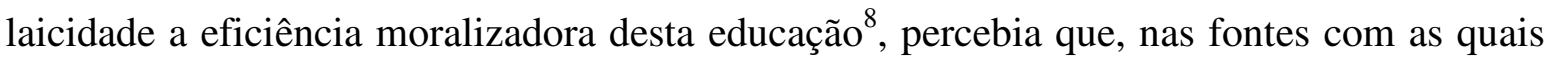
eu estava trabalhando, este discurso da laicidade, e da civilidade, também estava presente, mas junto com ele estava o discurso religioso e ainda o discurso psicológico - por vezes os três eram encontrados na mesma fonte e citados pelo mesmo autor. Esse conhecimento foi fundamental para ampliar o modo de olhar para o meu objeto de pesquisa, o tratamento dado às minhas fontes e para compreender a questão investigada.

O estudo desenvolvido no âmbito do mestrado acerca do uso dos uniformes escolares nas instituições de ensino paulistas, no período de expansão da escola pública, fez emergir a seguinte questão: por que é necessário uniformizar e padronizar os corpos e as condutas? Buscando respostas para essa pergunta outra surgiu e, como complemento da primeira, parecia ser o cerne da questão. Por que e de que forma estiveram presentes as práticas de moralização na escola durante o seu período de expansão, justamente o período no qual a escola passou a receber uma clientela de origem social bastante distinta daquela que até então vinha freqüentando os bancos escolares? Em 1930 se configurou mais fortemente um processo de expansão das oportunidades de educação primária e a escola, nesse nível de ensino, começou a se estender a significativas parcelas da população na cidade de São Paulo, iniciando o processo a expansão da escola de massas, que teria seu ápice três décadas mais tarde. A instrução secundária pública, naquela época, ainda tentava introduzir um padrão de ensino dotado de uma organização própria e que pudesse servir de modelo para a constituição de estabelecimentos educacionais particulares. Estas instituições, por sua vez, tiveram sua origem na estrutura e nos valores predominantes durante o Império. A divisão da escola secundária em aulas avulsas destinadas à preparação dos exames parcelados não permitiu, da parte do poder imperial, uma orientação uniformizada durante o século XIX. A criação dos liceus provinciais não teve sucesso, já que eles não obtinham os mesmos privilégios que o Colégio Pedro II, localizado no Rio de Janeiro. Prevaleceu, nas províncias, que depois se transformariam em Estados, a supremacia do ensino particular, leigo ou religioso. Em 1883, na Província de São Paulo, só existia uma escola pública, onde estavam matriculados trinta alunos. O primeiro ginásio oficial do município de São Paulo foi criado em 1892. Era o ginásio do Estado, criado a fim de

\footnotetext{
${ }^{8}$ O livro de Pierre Ognier, por exemplo, é exemplar acerca desta questão: OGNIER, P. Une école sans Dieu? 1880-1895: L'invention d'une morale laïque sous la IIIe. République, Toulouse: PUM, 2008.
} 
"encerrar o funesto período escolar em que um menino de dez anos transpunha de um salto (dois ou três anos) a distância do analfabeto ao ensino superior, e abrir a era de estudos sérios, sem as ilusões universitárias, com exclusivo fito num sólido preparo para a vida". (SPOSITO, 1984, p. 42) Durante a primeira república, período que vigorou entre 1889 e 1930, o ensino secundário visava atender às exigências de uma educação destinada a selecionar e preparar a elite do país. No Estado de São Paulo, o decreto 13.542, de 9 de setembro de 1943, transformou os ginásios do Estado em colégios. A partir de 1945, o poder público tendeu a responder às demandas de escolaridade após o curso elementar, criando uma rede de estabelecimentos secundários onde passaram a funcionar os cursos ginasiais. Foi também neste período que teve início o processo de expansão das possibilidades de acesso à escola secundária pública. Em 1947, a iniciativa oficial compreendia 6,2\% do total de matrículas escolares, em 1960, esta porcentagem já atingia $40,9 \%$ do total e, em 1970, a iniciativa oficial superou a particular com $75,4 \%$ das matrículas.

No Estado de São Paulo, nos anos de 1960, quase toda a população em idade escolar já estava matriculada no ensino primário. Além de investir na construção de edifícios escolares, o governo estadual promoveu outras medidas aumentar o acesso à educação, como a redução do número de anos do ensino primário e a ampliação dos turnos dos grupos escolares. Segundo Celso de Rui Beisiegel (1974), a propósito da democratização do acesso à escola pública, nos anos de 1970: “a expansão das oportunidades já alcança também aqueles contingentes populacionais não absorvidos pela escola no passado, quando a oferta de vagas nos diversos níveis de ensino ainda não se estendia a todos os setores da coletividade. Somados aos cursos comuns do ensino de nível primário e médio, o denominado curso supletivo de nível primário e os cursos de preparação para os exames de madureza, de $1^{\circ}$ e $2^{o}$ ciclos, criaram condições institucionais de atendimento escolar de toda a população do Estado" (op. cit., p. 2). No entanto, a introdução de uma clientela escolar de origem mais pobre que a escola pública paulista conheceu durante o seu período de expansão não encontrou mudanças em relação à expectativa dos professores quanto ao seu desempenho nos estudos. No Estado de São Paulo, entre os anos de 1968 e 1970 a secretaria da educação formulou e executou uma política de expansão do ensino ginasial. Com o primário praticamente universalizado, esse ciclo de ensino havia sido transformado no ponto de "estrangulamento" do sistema escolar, deslocando a exigência democratizadora do 
primário para o ginásio (AZANHA, 1987). Obrigatórios por lei federal, os exames de admissão a esse nível de ensino haviam configurado uma barreira difícil de ser ultrapassada pela grande massa dos alunos de vinham do ensino primário. Esses exames eram elaborados pelas próprias escolas com extremo rigor, de modo a impedir o impasse entre candidatos aprovados e sem matrícula. Com o objetivo de promover a expansão de vagas, a Secretaria reduziu as exigências e unificou a elaboração das provas, o que proporcionou a aprovação da maioria dos candidatos. A expansão das matrículas causou uma intensa ocupação do espaço escolar, multiplicando os períodos de aulas. O problema da expansão, nesse caso, consistiu na resistência de grande parte do magistério à nova clientela escolar, alegando rebaixamento da qualidade do ensino. De acordo com José Mário Pires Azanha (1987), a resistência dos professores assumiu a forma de uma "profecia auto-realizadora": "fundado na convicção de uma inevitável queda da qualidade do ensino, o professorado não procurou se ajustar à nova realidade da clientela escolar e insistiu na manutenção de exigências intracurso que anulariam pela reprovação maciça o esforço da abertura escolar. Não se alegue que isso seria a evidência empírica da queda do nível de ensino. Ao contrário, nível de ensino não é variável abstrata, e reprovação em massa é sempre índice de defasagem entre critérios de exigência e reais condições de ensino-aprendizagem” (op. cit., p. 33). Para contornar o problema da reprovação maciça, causada pelas expectativas dos professores em relação à clientela escolar, a Secretaria instituiu um sistema de pontos que pesava na recontratação dos professores. O período escolhido para o desenvolvimento da pesquisa compreende um momento de grande agitação entre as entidades representativas do magistério primário, com a promoção dos congressos nacionais. Nesta época, considera-se que o ensino ganhou um caráter de cientificidade, ele passou a ter um aspecto "técnico", dominado por especialistas. O poder estatal buscava racionalizar o sistema de ensino, tornando-o mais eficiente. O processo de "racionalização" do trabalho docente, isto é, a

\footnotetext{
${ }^{9}$ Lenore Jacobson e Robert Rosenthal (1981), em uma pesquisa realizada nos Estados Unidos nos anos 1960, apresentaram aos professores classes consideradas fortes como fracas e classes consideradas fracas como fortes, e defenderam que as crianças das quais os docentes esperavam um maior desenvolvimento da capacidade intelectual de fato apresentariam este desenvolvimento. Os experimentos realizados pelos autores comprovaram a proposição: as expectativas dos docentes de fato funcionaram como "profecias autorealizadoras" porque o desempenho dos alunos coincidiu com o que era desejado pelos professores ou, ao menos, foi assim que o desenvolvimento das crianças foi percebido e avaliado.
} 
perda de autonomia acerca do próprio trabalho, desencadeou menores salários e menor qualificação. Em 1955, começaram a ser criados os Centros Regionais de Pesquisa Educacional (CRPE), com o objetivo de utilizar as metodologias das ciências sociais para investigar e executar experiências educacionais em diversas regiões do país e, ainda, formar especialistas em educação, que iriam ocupar postos de direção da administração do ensino (LUGLI, 2002). A docência sofre então um processo de dicotomia: há os especialistas que produzem teorias e refletem sobre o ensino e há os professores, considerados executores de um trabalho elaborado por representantes de uma outra esfera, que ocupam um lugar mais elevado na hierarquia da profissão. Em conflito entre suas necessidades econômicas e o sacerdócio, associado aos valores originários da profissão, os professores só aderem a uma greve, reivindicando por seus interesses e melhores salários, em 1963. Em 1971, é promulgada a $\mathbf{L D B} \mathbf{n}^{\mathbf{0}} \mathbf{5 . 6 9 2}$, que instaura o $1^{\circ}$ grau de 8 anos, definindo um novo período em relação ao estatuto profissional do professor primário. Em 1978, há o ressurgimento da categoria profissional na cena pública, com a emergência das tendências consideradas de "esquerda" no movimento docente, contrapondo-se às associações que tradicionalmente os representavam. No caso de São Paulo, uma das associações mais tradicionais é o Centro do Professorado Paulista (CPP), cujo periódico, a Revista do Professor (1934-1965), é tomada como fonte neste trabalho.

Moralizar é importante para a continuidade da sociedade, para a vida em comunidade, para enquadrar os comportamentos em uma norma aceitável socialmente, para o desenvolvimento do autocontrole em cada um dos sujeitos. Por se tratar do período de democratização de oportunidades de educação pública e do fato de a escola receber os mais pobres, talvez as práticas de moralização tenham sido mais acentuadas ou necessárias? Era preciso controlar a conduta, enquadrar todos em um padrão de comportamento. Como a escola trabalha para auxiliar cada um a controlar as suas paixões, a dominar-se e a conterse, culminando na domesticação do sujeito? Com o objetivo de responder a essas questões foi preciso buscar a literatura produzida sobre o tema e o livro A Educação Moral, do francês Émile Durkheim, constituiu-se em importante referência para o início da reflexão. Não se trata de um estudo comparado entre as práticas de moralização ou mesmo a educação moral ministrada na França e no Brasil, contudo, a literatura francesa é de extrema importância para pensarmos esta questão no caso brasileiro. Logo no começo do livro, que é produto das primeiras aulas que ele ministrou na Sorbonne em 1902, ocupando 
a cadeira de pedagogia, o autor escreveu o seguinte: "Se tomei como tema do curso o problema da educação moral (...) é porque ele se coloca hoje sob condições de particular urgência. De fato, é nesta parte do nosso sistema pedagógico tradicional que a crise (...) atinge seu máximo de gravidade (...) tudo o que arrisca diminuir a eficácia da educação moral, tudo o que arrisca tornar sua ação mais incerta, ameaça a moralidade pública em sua própria fonte." (p. 2-3) Para Durkheim, a moral consiste em um conjunto regras especiais, precisas e definidas que foram constituídas historicamente e que fixam a conduta dos homens nas diversas situações em que se apresentam cotidianamente, sob a influência de necessidades sociais determinadas. Segundo Heloísa Fernandes (1994): “É possível concluir que, após 20 anos de dedicação à tarefa da construção da ciência da moral, Durkheim reconhece-se como seu mestre fundador: sua ciência, embora ainda em seus primórdios, não se confunde com as invenções dos moralistas; corresponde às exigências de um ensino popular e infantil, tanto é que seus discípulos colocaram mãos à obra: seu método está sendo aplicado na escola primária e no liceu” (op. cit., p. 110-111). Além de destrinchar os elementos da moralidade laica, de uma "moral sem Deus", Durkheim dedicara-se à tarefa de compreender como são constituídos nas crianças os elementos da moralidade. Em sua concepção a educação está associada à moralização e à adesão dos indivíduos às normas de convivência social. Historicamente, o sociólogo francês entende que a verdadeira educação só começou no momento em que a cultura mental e moral adquirida pela humanidade tornou-se muito complexa, e a mesma desempenha um papel muito importante no conjunto da vida em comum para que seja deixada ao acaso a tarefa de assegurar sua transmissão de uma geração à outra.

Como forma de desenvolver a pesquisa e de compreender a maneira pela qual as práticas de moralização estiveram presentes na escola pública paulista em seu período de expansão mediante um diálogo entre as fontes consultadas e a bibliografia que subsidia a análise, propus a divisão do trabalho em três questões: religiosa, cívica (e de integração à comunidade) e psicológica (e de autogoverno). A divisão proposta para a análise é fruto da recorrência destes eixos ao longo do material analisado. No exame realizado em um dos conjuntos de fontes consultados, nos manuais de didática e metodologia do ensino, por exemplo, foi possível identificar a justificativa das orientações e o discurso sobre a moralização a partir dessas óticas: alguns livros usam mesmo as três para se dirigirem à questão. Transitando por três décadas de história através das fontes examinadas, foi possível 
identificar um discurso que visa a submeter os futuros professores e, conseqüentemente, os alunos à moralização mediante muitas justificativas, mas, principalmente, justificativas de cunho religioso, cívico ou psicológico, que são diferenciadas entre uma educação voltada para a alma, como os deveres, as obrigações e os direitos e outra voltada para o corpo, o cuidado consigo mesmo e com a comunidade. No que concerne à questão religiosa, foi surpreendente observar a maneira como o discurso cívico está atrelado ao discurso religioso. Diferentemente do caso da França, onde a moral religiosa foi substituída por uma moral laica, no Brasil, elas caminharam juntas, por mais que, teoricamente, tenha havido uma separação no plano da legislação.

\section{LEVANTAMENTO BIBLIOGRÁFICO}

Mediante um levantamento de teses e dissertações realizado em 2007 nos acervos da Faculdade de Educação da USP, da UNICAMP, da Pontifícia Universidade Católica de São Paulo e da UNESP, não foi possível identificar nenhum trabalho na área de Educação que tivesse como tema central as práticas e as representações de moralização na escola pública paulista entre os anos de 1948 a 1978. Entretanto, algumas pesquisas que tem como foco principal a religião, a disciplina educação moral e cívica, as relações de gênero ou a disciplina no cotidiano de instituições de ensino em determinadas condições históricas e sociais acabaram por discorrer sobre questões relacionadas à educação moral. Como é o caso, por exemplo, de trabalhos como o de Ana Laura Godinho Lima ${ }^{10}$ (1999), intitulado

De como ensinar o aluno a obedecer (um estudo dos discursos sobre a disciplina escolar entre 1944 a 1965), em sua dissertação, a autora investiga os valores morais e as estratégias disciplinares que regularam a conduta docente e discente nas escolas primárias paulistas no período mencionado, examinando também a maneira pela qual o problema da indisciplina era explicado por integrantes prestigiados do magistério. A tese de doutorado de Lusia Pereira Ribeiro ${ }^{11}$ (1996) intitulada De donzela angelical e esposa dedicada... a profissional de educação investiga a presença do discurso religioso na formação das

\footnotetext{
${ }^{10}$ LIMA, Ana Laura Godinho Lima. De como ensinar o aluno a obedecer (um estudo dos discursos sobre a disciplina escolar entre 1944 a 1965), dissertação de mestrado, FEUSP, 1999.

${ }^{11}$ RIBEIRO, Lusia Pereira Ribeiro. De donzela angelical e esposa dedicada... a profissional de educação, tese de doutorado, FEUSP, 1996.
} 
professoras, analisando o mesmo mediante a perspectiva das relações de gênero. Nelson Viana dos $\operatorname{Santos}^{12}$ (1995), na dissertação intitulada Militarização da educação no Estado Novo, estudou a influência que o discurso militar em voga durante a ditadura do Estado Novo exerceu sobre a educação. Maricilde Oliveira Coelho ${ }^{13}$ (2004) na dissertação intitulada Proclamar cidadãos: moral e civismo nas escolas públicas paraenses (18901910) investiga, segundo termo utilizado pela autora, "táticas" de formação moral e cívica nas práticas cotidianas da escola primária, que tinham por objetivo inserir os alunos em um sistema de valores necessários à aquisição da nacionalidade e à formação para a cidadania. Marta Maria Chagas de Carvalho ${ }^{14}$ (1998) no trabalho intitulado Molde nacional e fôrma cívica: higiene, moral e trabalho no projeto da Associação Brasileira de Educação (1924-1931) estudou as propostas da $A B E$ visando à desmistificar o pensamento educacional dos anos de 1920 e 1930. Segundo a autora, a ABE, formada por intelectuais, era uma instância que procurava conquistar poder político ao se auto-intitular defensora do progresso nacional através da educação. Tais propostas retratavam o povo brasileiro como degenerado, sujo e ignorante e disseminavam ideais e práticas educacionais que almejavam o controle social. Desta forma, a educação deixava de ser um direito popular e passaria a ser um dever, já que traria ao povo inculto e incivilizado a sua salvação como nação. Nessas condições históricas e sociais, seria preciso educar para moralizar os costumes, organizar a população, homogeneizar as escolas e sanear as massas, atualizando o Brasil em relação aos valores requeridos pela organização racional do trabalho, que estava surgindo no período posterior à primeira guerra mundial. Assim, se à elite estava reservada a educação secundária e a universidade, que formaria os filhos da classe dominante para dirigir o país rumo ao progresso, ao povo estava destinada uma educação primária fundamentada em valores considerados necessários ao adestramento da classe operária, como a saúde, a moral e o trabalho. A dissertação de mestrado de Maria Aparecida de Freitas Brisolla de Oliveira ${ }^{15}$

\footnotetext{
${ }^{12}$ SANTOS, Nelson Viana dos. Militarização da educação no Estado Novo, dissertação de mestrado, FEUSP, 1995.

${ }^{13}$ COELHO, Maricilde Oliveira. na dissertação intitulada Proclamar cidadãos: moral e civismo nas escolas públicas paraenses (1890-1910), dissertação de mestrado, FEUSP, 2004.

${ }^{14}$ CARVALHO, Marta Maria Chagas de. Molde nacional e fôrma cívica: higiene, moral e trabalho no projeto da associação brasileira de educação (1924-1931) Bragança Paulista: EDUSF, 1998.

15 OLIVEIRA, Maria Aparecida de Freitas Brisolla de. Política e Educação no Brasil: A implantação da obrigatoriedade da Educação Moral e Cívica no ensino brasileiro em 1969, dissertação de mestrado, FEUSP, 1982.
} 
(1982) intitulada Política e Educação no Brasil: A implantação da obrigatoriedade da Educação Moral e Cívica no ensino brasileiro em 1969 apresenta uma caracterização do regime político brasileiro no período pós-1964 e estuda as origens da idéia no ensino de educação moral e cívica e sua inserção no sistema de ensino nacional. A dissertação de mestrado de Geni Rosa Duarte ${ }^{16}$ (1995), intitulada Rumo ao campo: a civilização pela escola analisa as propostas formuladas para a educação rural entre os anos de 1910 a 1930, que justificavam a escolarização como forma de integrar essa população ao mundo do trabalho, mediante um processo de higienização, moralização e homogeneização cultural. O trabalho de Heloísa Rodrigues Fernandes ${ }^{17}$ (1994) intitulado Sintoma social dominante e moralização infantil analisa a obra de Émile Durkheim como exemplar do projeto de moralização laica, sustentando que ali o dispositivo pedagógico que é construído não está comprometido com o ideal da autonomia de cidadãos livres e responsáveis, mas sim, tratase de um subtituto da moralização cristã. Como tal, seus efeitos são similares: "identificação com a norma; submissão, demanda de crença no Outro, único a decidir, providencial e onipotente, sobre os destinos da vida individual e coletiva" (op. cit., 15). Antes de passar à análise que visa a compreender como as práticas e as representações de moralização estiveram presentes na escola pública entre os anos de 1948 a 1978, é necessário explicar o emprego das fontes nessa pesquisa. Convém ressaltar que a presença das fontes ao longo dos capítulos não obedece a uma ordem cronológica de publicação das mesmas, mas atende a uma necessidade surgida de sua própria análise em função da questão investigada: os periódicos educacionais, os manuais pedagógicos e a legislação vão sendo referenciados ao longo do trabalho em função das práticas e das representações de moralização encontradas durante o exame deles próprios, que deram origem aos capítulos e aos subtítulos da tese.

\footnotetext{
${ }^{16}$ DUARTE, Geni Rosa. Rumo ao campo: a civilização pela escola, dissertação de mestrado, PUC-SP, 1995.

${ }^{17}$ FERNANDES, H. R. Sintoma social dominante e moralização infantil São Paulo :Edusp/Escuta, 1994.
} 


\section{FONTES}

Nesta parte do trabalho procura-se explicitar as formas pelas quais as diferentes fontes: os periódicos educacionais, os manuais pedagógicos e a legislação educacional puderam contribuir para a compreensão da forma como as práticas e as representações de moralização se configuraram entre os anos de 1948 e 1978 na escola pública paulista. Inicialmente realiza-se uma caracterização acerca do tipo de estudo efetuado a partir dos periódicos educacionais, procurando explicitar maneira pela qual os artigos foram selecionados para esta tese. A seguir, são apresentadas as características gerais das revistas examinadas e dos textos por ela veiculados que fizeram alguma referência ao tema estudado. A segunda parte desse texto é dedicada à caracterização dos manuais pedagógicos e à explicitação das contribuições que estes trouxeram à pesquisa, e a terceira parte apresenta a forma como foi realizado o estudo com a legislação educacional e o modo pelo qual essa fonte foi incorporada ao trabalho. É relevante evidenciar ainda que essa parte da tese pretende descrever como as fontes foram tratadas pela presente investigação e explicitar as características das mesmas. Contudo, a análise realizada a partir destas informações é efetuada ao longo dos capítulos seguintes.

Acerca do potencial que as revistas pedagógicas representam para os pesquisadores, Pierre Caspard acredita que através de seu uso enquanto fonte para pesquisas pode-se: "escrever a história da educação de um outro modo: menos centrado no papel do Estado ou dos grandes pedagogos e mais atento à riqueza das iniciativas locais, institucionais, ideológicas, sócio-profissionais e também ao atendimento de expectativas de vez que, diferentemente do livro, a imprensa periódica é uma mídia interativa na orientação da qual os leitores participam de um modo ou de outro, quer escrevendo para ela, quer assinando ou deixando de fazê-lo" (1993, p. 93 apud CATANI; SOUSA, 1999, p. 14) Segundo Caspard, a expressão "imprensa de ensino" refere-se ao conjunto de revistas, destinadas aos professores, que visam guiar o trabalho docente no seu cotidiano, oferecendo-lhes informações sobre a didática das disciplinas, o manejo da classe e o conteúdo dos programas oficiais. A imprensa educacional é um corpus documental que possui muitas dimensões visto que apresenta métodos e concepções pedagógicas de uma época. Segundo Catani e Bastos (1997) os periódicos educacionais são fontes férteis de estudo porque tornam-se “...um guia prático do cotidiano educacional e escolar, permitindo ao pesquisador 
estudar o pensamento pedagógico de um determinado setor ou de um grupo social a partir da análise do discurso veiculado e da ressonância dos temas debatidos, dentro e fora do universo escolar". (op. cit., p. 5) Desta forma, a escolha de dois periódicos de natureza bastante distinta - a Revista Brasileira de Estudos Pedagógicos, apresentando um caráter mais acadêmico e pretendendo-se científica, e a Revista do Professor, produzida por uma associação docente - torna possível o acesso tanto aos discursos produzidos por pesquisadores, educadores e autoridades de reconhecido prestígio no campo educacional, como é o caso da RBEP, quanto aos textos escritos por professores primários, inspetores de ensino e diretores de escola, publicados na RP.

É importante declarar também a forma como foram selecionados os artigos nas revistas consultadas. Com o objetivo de localizar referências que evidenciassem como estiveram presentes as práticas e as representações de moralização na escola, foram examinados textos que, de alguma forma, fizessem referência a esta questão. As informações localizadas foram encontradas em textos que tratavam dos mais variados temas, como, por exemplo: disciplina escolar, manejo da classe, reformas educacionais, formação de professores, educação musical, educação moral e cívica, entre outras questões. Desta forma, realizou-se a localização das seguintes palavras: moral, moralização, e também, uniformização e padronização. A partir da leitura dos artigos foi possível perceber que foram utilizadas pelos autores algumas figuras que definiram as práticas e as representações de moralização. O trabalho docente, por exemplo, revestido pelo sacerdócio, era visto muitas vezes como uma “missão". Desta forma, a listagem a seguir é fruto de um esforço em apresentar como alguns termos comuns na literatura pedagógica, ao relacionarem-se à moralização, foram representados nos discursos veiculados pelas fontes consultadas:

\section{Figura}

Adolescência

"Bom aluno"

Caráter

Castigo

\section{Representação}

fase da vida perigosa devido à contestação e à rebeldia dos sujeitos asseado, sincero, responsável esforço, obediência, resistência, coragem, perseverança, busca pela verdade, solidariedade, respeito embrutece, educa, causa revolta, lesa a formação moral

Crianças pobres desajustados, anormais, delinqüentes, 


\begin{tabular}{|c|c|}
\hline & rebeldes \\
\hline Crianças desajustadas & devem ser tratadas \\
\hline Crianças indisciplinadas & devem ser corrigidas \\
\hline Crianças mal alimentadas & apáticas, preguiçosas, vadias \\
\hline Educação escolar & $\begin{array}{l}\text { promoção do autogoverno, da } \\
\text { democracia, da felicidade, do } \\
\text { autocontrole nos sujeitos; } \\
\text { desenvolvimento do caráter }\end{array}$ \\
\hline Escola Nova & $\begin{array}{l}\text { salvação, solução para a indisciplina, } \\
\text { dinâmica, ensinar o autogoverno e a } \\
\text { "querer o que se deve" }\end{array}$ \\
\hline Educação progressista & $\begin{array}{l}\text { proporcionar mudanças sem ocasionar } \\
\text { desordem }\end{array}$ \\
\hline Exercício do magistério & $\begin{array}{l}\text { exige dom, autocontrole, saúde mental, } \\
\text { doação }\end{array}$ \\
\hline Família & proteção, autodefesa \\
\hline Lazer & $\begin{array}{l}\text { educativo, observado, orientado, } \\
\text { moralizador }\end{array}$ \\
\hline Liberdade & $\begin{array}{l}\text { controlada, utilizada com } \\
\text { responsabilidade, disciplina de si }\end{array}$ \\
\hline Literatura & $\begin{array}{l}\text { deve trazer exemplos de conduta, } \\
\text { estimular o patriotismo, o civismo, ser } \\
\text { orientada e moralizadora }\end{array}$ \\
\hline Meios de comunicação & ameaça, perigo \\
\hline $\begin{array}{l}\text { Motivação para a realização do } \\
\text { trabalho docente }\end{array}$ & $\begin{array}{l}\text { amor às crianças, à Pátria, ao ensino, } \\
\text { a Deus }\end{array}$ \\
\hline Música & $\begin{array}{l}\text { deve educar, desenvolver sentimentos } \\
\text { cívicos, patrióticos; disciplina, } \\
\text { formação do caráter }\end{array}$ \\
\hline Palmatória deve ser substituída por & $\begin{array}{l}\text { manejo, governo de si, } \\
\text { bons exemplos, vergonha, } \\
\text { máxima ocupação do tempo }\end{array}$ \\
\hline Pátria & proteção \\
\hline Personalidade do aluno & $\begin{array}{l}\text { deve ser moldada e corrigida pela } \\
\text { educação escolar }\end{array}$ \\
\hline Personalidade do professor & dela depende o trabalho docente \\
\hline Professor & médico escolar, padre \\
\hline Professora primária & $\begin{array}{l}\text { figura exemplar, delicada, simpática, } \\
\text { alegre, santa, mãe, dedicada, paciente, } \\
\text { tolerante, humilde, honesta, amável, } \\
\text { compreensiva }\end{array}$ \\
\hline Rua & $\begin{array}{l}\text { lugar de vícios, malandragem, } \\
\text { desocupados; perigo }\end{array}$ \\
\hline
\end{tabular}




\begin{tabular}{|ll|}
\hline Trabalho & $\begin{array}{l}\text { dignidade, mobilidade social, realizado } \\
\text { pela Pátria, integração social }\end{array}$ \\
\hline Trabalho docente & $\begin{array}{l}\text { sacerdócio, missão, sacrifício, renúncia, } \\
\text { vocação, sagrado, apostolado }\end{array}$ \\
\hline
\end{tabular}

Nesse sentido, os textos selecionados versaram principalmente sobre os seguintes temas:

Formação de professores e orientação da conduta docente de acordo com a moral e os bons costumes - professores como exemplo;

Valores cristãos e religião na orientação tanto da formação dos alunos quanto dos professores;

Programas de ensino: importância das disciplinas história e geografia, além da educação moral e cívica, para ensinar aos alunos valores morais e patriotismo;

Disciplina, ordem e asseio: a conduta dos alunos de acordo com a moral e os bons costumes;

Comemorações cívicas, festejos e desfiles patrióticos aliados aos princípios morais e aos valores nacionalistas que deveriam ser ensinados na escola;

Educação musical: a função moralizadora da música e sua importância para o desenvolvimento do patriotismo;

Psicologia e formação da personalidade.

Da análise dos artigos da revistas, assim como do exame dos manuais pedagógicos, foi possível depreender que os discursos acerca da moralização na escola eram mesclados por três dimensões: religiosa, cívica e psicológica. Não se trata de textos que correspondiam exclusivamente a cada um desses eixos, mas sim a uma mistura de referências utilizadas por grande parte dos autores. Foi a partir do tratamento das fontes que se evidenciou esta natureza tríplice de justificativas acerca da necessidade de conformar moralmente os sujeitos e a estrutura da tese obedece a esta lógica. Dividida inicialmente em três partes, ela se desdobra em cinco capítulos que visam a compreender como a moralização, entendida 
aqui como a moral praticada e inserida na alma e no comportamento das pessoas existiu enquanto prática e representação nas escolas públicas paulistas entre 1948 e 1978. Assim, com freqüência, referências a um mesmo artigo poderão ser encontradas em vários capítulos deste trabalho por obedecerem não a uma classificação temporal ou temática originária dos próprios temas desses textos, mas sim a uma idéia derivada do próprio desenvolvimento da pesquisa aqui apresentada.

\section{OS PERIÓDICOS EDUCACIONAIS}

O estudo de periódicos educacionais constitui uma importante fonte de pesquisa, sendo que os mesmos eram uma espécie de porta-voz dos grandes educadores da época, formadores de todo um discurso que influenciava as práticas docentes. Tomar as revistas como fontes para a investigação permite conhecer o discurso considerado legítimo sobre as questões educacionais, assim como as recomendações e prescrições acerca das formas ideais de realização do trabalho docente. Além disso, elas possibilitam o entendimento entre o discurso oficial e a prática cotidiana (CATANI; SOUSA, 1999). Para o presente estudo foram selecionados artigos que de alguma forma fizeram menção a práticas e representações de moralização na escola e foram publicados entre 1948 e 1978 na Revista Brasileira de Estudos Pedagógicos - RBEP (Instituto Nacional de Estudos Pedagógicos) e entre 1948 e 1965 na Revista do Professor - RP (Centro do Professorado Paulista). 


\section{REVISTA BRASILEIRA DE ESTUdOS PEDAGÓGICOS (RBEP) ${ }^{18}$}

A Revista Brasileira de Estudos Pedagógicos (RBEP) surgiu em julho de 1944. Inicialmente teve sua publicação mensal, até fevereiro de 1946, tornando-se bimestral até 1948. A partir de então, ela passou a ser quadrimestral, até que, em 1951, tornou-se trimestral, tendo esta mesma periodicidade até 1964. Editada até dezembro de 1976 no Rio de Janeiro, a RBEP passou a ser editada, a partir de janeiro de 1977, em Brasília. Ela constitui um periódico de caráter oficial, publicado pelo Instituto Nacional de Estudos Pedagógicos (INEP). Seus artigos representam o discurso que era considerado legítimo sobre o ensino, demonstrando a visão de autores prestigiados e com autoridade no espaço educacional para definir que questões deveriam ser examinadas e privilegiadas nos debates. O periódico apresenta referenciais teóricos, propostas modelares de organização do sistema de ensino e suas origens, compreendidos como elementos que moldaram o discurso pedagógico nacional. Atualmente a revista tem periodicidade quadrimestral. Além de artigos, resenhas e resumos de livros, ela é rica em dispositivos legais utilizados pelo Estado para organizar o sistema de ensino. Ao longo de seu ciclo de vida, transcreveu leis, decretos e atos oficiais.

Jader de Medeiros Britto, no editorial comemorativo de 150 números da RBEP sugere que o período de publicação da revista seja dividido em quatro fases. A primeira fase é caracterizada pela presença de Lourenço Filho e depois de Murilo Braga Carvalho na diretoria do INEP. Esta fase conta com os 45 primeiros números do periódico e ocorre entre julho de 1944 e março de 1952. A gestão de Anísio Teixeira marca a segunda fase, entre os anos de 1952 a 1964, quando são publicados 48 números. A terceira fase é marcada pela saída de Anísio Teixeira do INEP e termina em 1980, quando a publicação do periódico é interrompida por três anos (GIL, 2002). Na primeira fase, é marcante a intenção de

\footnotetext{
18 As informações sobre o ciclo de vida da Revista Brasileira de Estudos Pedagógicos podem ser encontradas nos trabalhos realizados por Ana Laura Godinho Lima, De como ensinar o aluno a obedecer (um estudo dos discursos sobre a disciplina escolar entre 1944 a 1965), dissertação de mestrado, FEUSP, 1999 e por Natália de Lacerda Gil, Razão em números: a presença das estatísticas nos discursos educacionais divulgados na Revista Brasileira de Estudos Pedagógicos (1944-1952), dissertação de mestrado, FEUSP, 2002.
} 
promover, por especialistas da área da educação, o debate das questões educacionais. A segunda fase dedica maior atenção às pesquisas sobre educação, articuladas à pedagogia, biologia e psicologia. Também é evidenciado o envolvimento do periódico no debate acerca da Lei de Diretrizes e Bases da Educação Nacional que foi promulgada em 1961. A discussão acerca de questões relacionadas à administração do ensino, a realização do censo escolar, a formação dos professores e o planejamento do ensino marcam a terceira fase (LIMA, 1999). Sendo a RBEP um periódico de caráter oficial, publicou, em suas três fases, artigos que apresentavam dados e considerações acerca de vários Estados brasileiros, assim como resultados de trabalhos realizados pelos diferentes órgãos do Ministério e pelas Secretarias Estaduais de Educação.

Para o estudo das práticas e das representações de moralização na escola no âmbito da RBEP demonstraram-se muito férteis três seções em especial, são elas: "Idéias e debates", "Através de Revistas e Jornais" e "Documentação". A primeira seção apresenta maior destaque no corpo da revista e encontra-se no início do periódico, após o editorial. Os artigos contidos nessa parte são mais longos e apresentam um aprofundamento maior acerca do tema abordado. A segunda seção apresenta textos mais curtos e tem a intenção de transcrever aqueles que foram publicados na grande imprensa e em revistas pedagógicas em toda parte do país. Por fim, a seção "Documentação" apresenta debates sobre questões relacionadas à organização e à administração da educação nacional. Muitas vezes transcrevendo leis e decretos, tanto referentes ao período em que foram escritos os artigos, quando a períodos anteriores, inclusive ao século XIX. Estas duas últimas seções ocupam menor destaque e ficam situadas no final do corpo do periódico. A seguir, segue uma listagem com os 101 textos selecionados na RBEP para o desenvolvimento do presente estudo. Acompanhada da referência do artigo, há uma breve informação biográfica sobre o autor de cada um deles. Tais informações reunidas neste trabalho foram localizadas na própria revista e mediante pesquisas na internet.

\section{Listagem dos artigos selecionados na Revista Brasileira de Estudos Pedagógicos}

“I Encontro Nacional de Ed. Artística” (Documentação) RBEP, no 121, jan./mar. 1971, p. $170-179$.

"X Conferência Nacional de Educação" (Documentação) RBEP, no 48, out./dez. 1952, p. $177-189$. 
"XV Conferência Internacional de Instrução Pública" Realizada em Genebra e promovida pela ONU e pelo Bureau Internacional de Educação. (Documentação) RBEP, no 49, jan./mar. 1953, p. 92 - 99.

"A formação de professores" Trata-se do relatório apresentado na Conferência das Escolas para a Compreensão Internacional, em colaboração com a UNESCO, em 1955. RBEP, no 64, out./dez. 1956, p. 141 - 179.

ABREU, Jaime. (Diretor da Divisão de Estudos e Pesquisas Educacionais do CBPE) "Os estudos sociais na escola média" (artigo publicado inicialmente no Correio do Senac, Rio) RBEP, no 82, abr./jun. 1961, p. 151 - 154.

ADISESHIAH, Malcolm S. (Diretor-Geral Adjunto da UNESCO), "Ano Internacional da Educação" (Informações da UNESCO, janeiro 1970 e Boletim da AIU, V. XVIII, 1970, n. 1) (traduzido do francês pelo Prof. Celso Barroso Leite) RBEP, no 119, jul./set. 1970.

ALENCAR, Eunice M. L. Soriano de. (Professora do Departamento de Psicologia da Universidade de Brasília) "Relação entre o nível de criatividade do professor e de seus alunos" RBEP, no 139, jul./set. 1976, p. 376 - 380.

ANTIPOFF, Helena. (Fundadora da Sociedade Pestalozzi do Brasil em Minas Gerais e no Rio de Janeiro; do Centro de Orientação Juvenil do Ministério da Saúde; da Associação Milton Campos para Assistência às Vocações do Bem-Dotado (ADAV) que operacionaliza o Projeto CIRCULA (Civilização Rural Cultural e Lazer), na Fazenda do Rosário em Minas Gerais, e do Instituto Superior de Educação Rural em Ibirité, MG.) "O problema do bemdotado no meio rural" RBEP, no 139, jul./set. 1976, p. 417 - 428.

AUGRAS, Monique. (Doutora em Psicologia - Sorbonne. Professora Titular do Curso de Psicologia do ISOP/FGV) “Mitos brasileiros em literatura infantil” RBEP, no 141, jan./abr. 1977, p. $27-35$.

AZEVEDO, Fernando de. (Sociólogo, escritor, redator do "Manifesto dos Pioneiros da Educação Nova”, em 1932, Diretor Geral da Instrução Pública do Estado de São Paulo em 1933, presidente da Associação Brasileira de Educação em 1938, professor da Universidade de São Paulo) "Educação e liberdade" (publicado inicialmente no jornal 0 Estado de S. Paulo) RBEP, no 60 out./dez. 1955, p. 243 - 249.

AZEVEDO, Fernando de. "Horizontes perdidos e novos horizontes (A educação primária na sociedade atual)" RBEP, no 65, jan./mar. 1957, p. 47 - 64.

BARROS, Romualdo Monteiro de. (Professor) (artigo publicado inicialmente na Folha de Minas, Belo Horizonte) “Qualidades do professor” RBEP, no 50, abr./jun. 1953, p. 166 169. 
BAUZER, Riva. (Professora de psicologia da FGV) (Boletim da CBAI, Rio) “Conceituação de Personalidade" RBEP, № 55, jul./set. 1954, p. 180 - 185.

BAUZER, Riva. (Formação, Rio) "Personalidade do professor primário" RBEP, no ${ }^{0}$, out./dez. 1954, p. 221 - 223.

BLOOMFIELD, U. E. (Professor inglês e representante do Conselho Britânico) "Um inspetor de escola secundária na Inglaterra" RBEP, no 53, jan./mar. 1954, p. 58 - 63.

Boletim da CBAI, Rio. (Através de Revistas e Jornais) "Significado da educação liberal" RBEP, no 48, out./dez. 1952, p. 296 - 304.

BREJON, Moysés. (Professor da Universidade de São Paulo) "Educação, fator de produção" (publicado inicialmente n'O Estado de S. Paulo) RBEP, no 99, jul./set. 1965, p. 207 - 208. CAMPOS, Paulo de Almeida. (Pesquisador do INEP) "Seminário regional sobre planos e programas da escola primária" RBEP, no 64, out./dez. 1956, p. 73 - 93.

CAMPOS, França. (Professor) (publicado inicialmente em Educação, Rio) "Organização e administração de atividades extra-classe" RBEP, no 50, abr./jun. 1953, p. 155 - 159.

CARVALHO, Irene Mello. (Diretora da Divisão de Ensino da FGV) "Disciplina e liderança" (publicado inicialmente em Escola Secundária, Rio) RBEP, no 73, jan./mar. 1959, p. 147 152

CASTELO BRANCO, Humberto. (Presidente da República) "Pela democratização do ensino" RBEP, no 98, abr./jun. 1965, p. 165 - 167.

CASTRO, Amélia Domingues de. (Professora de Didática da Faculdade de Educação da Universidade de São Paulo) "Fundamentos psicológicos da didática. Enfoque piagetiano" RBEP, no 133, jan./mar. 1974, p. 9 - 21.

CHAGAS, Valnir.(Membro do Conselho Federal de Educação) "Núcleo comum para os currículos do ensino de 1o e 2o graus" RBEP, no 125, jan./mar. 1972, p. 32 - 58.

COSTA, Rui Carrington da. (Professor do Liceu Nacional de Braga, Portugal) "Acerca do estudo eficiente" RBEP, no 50, abr./jun. 1953, p. 94 - 124.

COUNTS, George S. (Professor da Universidade de Columbia, EUA) "A educação dos Estados Unidos através do espelho soviético" RBEP, no 50, abr./jun. 1953, p. 44 - 53. COUTINHO, Afrânio. (Professor da Universidade do Distrito Federal) "O homem moderno e o humanismo" RBEP, no 65, jan./mar. 1957, p. 16 - 27.

"Declaração do Concílio Ecumênico sobre Educação Cristã" (Documentação) RBEP, no 100, out./dez. 1965 , p. $387-395$.

"Declaração dos direitos da criança” (Documentação) RBEP, nº 143, jan./abr. 1979, p. 229 $-230$ 
DODERER, Klaus. (Diretor do Instituto de Pesquisa de Literatura Infantil e Juvenil da Johann Wolfgang Goethe Universität, em Frankfurt, RFA) Trad. Ana Lúcia Tamm de Araújo Moreira. "A influência exercida pela literatura sobre crianças e jovens" RBEP, no 141, jan./abr. 1977, p. $17-25$.

"Educação e nacionalismo" (Anhembi, São Paulo) RBEP, no 80, out./dez. 1960, p. 204 209.

"Educação moral e cívica no currículo escolar" Em decorrência do decreto-lei no 869, de 12/9/69, foi instituída uma Comissão Nacional de Moral e Civismo. Esse decreto institui a Educação Moral e Cívica como disciplina obrigatória. RBEP, no 117, jan./mar. 1970, p. $151-176$.

"Escolares elegem dirigentes para Centros de Civismo" (Documentação) (publicado inicialmente no Jornal O Globo, Rio) RBEP, no 101, jan./mar. 1966, p. 158.

FERNANDES, Gonçalves. (Médico e escritor) "Higiene mental escolar" (inicialmente publicado na Revista de Ensino, Porto Alegre) RBEP, no 73, jan./mar. 1959, p. 135 - 147.

GAL, Roger. (Pesquisador do Instituto Pedagógico Nacional da França) "O ensino secundário e o mundo moderno" RBEP, nº 78, abr./jun. 1960, p. 19 - 27.

GASMANN, Lydinéa. (Professora da Faculdade de Educação da Universidade Federal do Rio de Janeiro e do Colégio Pedro II) "Possibilidade de uma didática não-diretiva: teoria de Rogers e didática" RBEP, no 124, out./dez. 1971, p. 408 - 420.

GOUVEIA, Aparecida Joly. (Antropóloga do Centro Regional de Pesquisas Educacionais de São Paulo) "Educação e desenvolvimento: pontos-de-vista dos professores secundários" RBEP, no 103, jul./set. 1966, p. 65 - 90.

HAVIGHURST, Robert J. (Pesquisador do INEP) "Tarefas evolutivas das crianças e dos adolescentes" RBEP, nº 67, jul./set. 1957, p. 130 - 143.

HOLLANDA, Guy de. (Professor e escritor) "Notas para a história da educação" RBEP, no 91, jul./set. 1963, p. $181-195$.

JONES, Esther Lloyd. (Professor da Universidade de Columbia, EUA) "A orientação como ensino em profundidade" RBEP, no 51, jul./set. 1953, p. 58 - 72.

KELLY, Celso. (Professor, escritor e diretor geral do Departamento Nacional de Ensino do Ministério da Educação) "A educação na assistência técnica" RBEP, no 54, abr./jun. 1954, p. $34-53$.

LEÃO, Emmanuel Carneiro. (Filósofo e escritor) “A viagem da educação" RBEP, no 144, mai./ago. 1979, p. $11-17$.

LESSA, Gustavo. (Médico e sanitarista, membro da Associação Brasileira de Educação e da 
FGV) (Educação, Rio) “A formação de hábitos na idade pré-escolar” RBEP, nº 50, abr./jun. 1953, p. $159-164$.

LIMA, Lauro de Oliveira. (Professor de psicologia da Universidade Federal do Ceará, membro do Conselho Estadual de Educação - RJ) "Instrução de ontem ou educação para amanhã" (artigo inicialmente publicado na Folha de S. Paulo) RBEP, no 109, jan./mar. 1968, p. 185 - 203.

LOURENÇO FILHO (Professor emérito da Universidade do Brasil, professor da Escola Normal Primária de São Paulo, professor de Psicologia e Pedagogia da Escola Normal de Piracicaba, diretor da Instrução Pública e professor da Escola Normal de Fortaleza, professor da Escola Normal de São Paulo, diretor de gabinete de Francisco Campos (1931), diretor geral do Departamento Nacional de Educação (nomeado por Gustavo Capanema, em 1937), diretor do Instituto Nacional de Estudos Pedagógicos, signatário do Manifesto dos Pioneiros da Escola Nova) "A educação nacional e o novo projeto de lei" RBEP, no 48, out./dez. 1952, p. 124 137.

LOURENÇO FILHO. “A propósito do centenário de John Dewey" (Educação, Rio) RBEP, no 82, abr./jun. 1961, p. $157-164$.

LOURENÇO FILHO “Dramatização de temas cívicos nas escolas” RBEP, no 81, jan./mar. 1961, p. 207 - 209.

MARINHO, Heloísa. (Professora do Instituto de Educação da Guanabara) (Correio da Manhã, Rio) “Magistério e vocação” RBEP, no 70, abr./jun. 1958, p. 136 - 138.

MARINHO, Heloísa. "Missão da educadora no jardim de infância” RBEP, n⿳0 101, jan./mar. 1966, p. $63-72$.

MARSH, Daniel L. (Professor) (inicialmente publicado na Revista do Professor - São Paulo) “Dignidade da profissão de ensinar” RBEP, no 49, jan./mar. 1953, p. 114 - 117.

MÁRQUEZ, Angel Diego. (Especialista em educação da UNESCO) "Renovação didática no ensino médio" RBEP, no 100, out./dez. 1965, p. 273 - 294.

MARTINS, Joel e TABA, Hilda. (Pesquisadores do CRPE) "Necessidade de analisar os objetivos do ensino" RBEP, no 72, out./dez. 1958, p. $39-45$.

MARTINS, Wilson. (Professor e escritor) "O novo Emilio (0 que a educação pode esperar das ciências sociais)" RBEP, no 66, abr./jun. 1957, p. 125 - 142.

MATA, Raimundo. (Professor) (Diário de Notícias, Salvador) "Criatividade: a nova dimensão educacional” RBEP, nº 93, jan./mar. 1964, p. 98 - 100.

MATTOS, Luiz Alves de. (Professor da Universidade do Brasil, Catedrático de Didática Geral e Especial; Diretor do Colégio de Aplicação da Faculdade de Educação da 
Universidade Federal do Rio de Janeiro; Ex-catedrático e ex-diretor da Faculdade de Educação da Universidade do Distrito Federal) (Educação, Rio) “A aprovação e a reprovação escolar" RBEP, nº 63, jul/set. 1956, p. 255 - 257.

MATTOS, Luiz Alves de. "A formação do moderno professor secundário" (inicialmente publicado em Escola Secundária, Rio) RBEP, no 71, jul./set 1958, p. 145 - 153.

MATTOS, Luiz Alves. "O exercício como procedimento de fixação de automatismos" RBEP, no 62 , abr./jun. 1956 , p. 56 - 74 .

MEDEIROS, Ethel Bauzer. (Pesquisadora do Instituto de Estudos Avançados em Educação, da FGV) "Brincar: uma das ocupações mais sérias da infância" RBEP, no 143, jan./abr. 1979 , p. $259-268$.

MELO, Maria Lúcia. (Socióloga do Departamento de Recursos Humanos da SUDAM) “Modelo experimental de cooperativismo nas escolas de $1^{\circ}$ e $2^{\circ}$ graus" RBEP, no 146, jan./abr. 1980, p. 383 - 389.

MENDONÇA, Nunes. (Professor e escritor) (artigo inicialmente publicado no Correio de Aracaju, Aracaju) “Educação e progresso social” RBEP, no 62, abr./jun. 1956, p. 149 - 153. MINICUCCI, Agostinho. (Professor da Escola Normal de Botucatu, SP e escritor) (artigo inicialmente publicado no Correio do SENAC, Rio) "As relações humanas e a nossa escola" RBEP, no 87, jul./set. 1962, p. 246 - 248.

MIRA, Maria Helena Novais. (Professora de Psicologia Escolar da Universidade Católica do Rio de Janeiro) “Condições emocionais para o exercício do magistério” RBEP, no 124, out./dez. 1971, p. $299-305$.

MOREIRA, J. Roberto. (Pesquisador do INEP) “Educação, sociedade e ideais educacionais" RBEP, no 65, jan./mar. 1957, p. 83 -100.

MOREIRA, J. Roberto. "Funções sociais e culturais da escola" RBEP, no 66, abr./jun. 1957, p. $53-81$.

NÉRICI, Imideo Giuseppe. (Professor da Universidade Mackenzie, da Faculdade Municipal de Filosofia, Ciências e Letras de Taubaté, das Faculdades Metropolitanas Unidas, da Faculdade de Filosofia, Ciências e Letras Oswaldo Cruz, Colégio Estadual e Escola Normal Dr. Alarico Silveira; Ex-professor na Faculdade de Filosofia da Universidade do Distrito Federal) (artigo inicialmente publicado no Correio da Manhã, Rio) "Formação do professor secundário" RBEP, no 65, jan./mar. 1957, p. 216 - 222.

NOVAES, Maria Helena. (Professora de Psicologia da Aprendizagem da Universidade Católica do Rio de Janeiro) "Características psicológicas do processo adaptativo dos superdotados" RBEP, no 139, jul./set. 1976, p. 359 - 366. 
ISAACS, Susan (Professora e escritora) "Os dez mandamentos dos pais e dos mestres" (trad. de Abgar Renault) RBEP, no 126, abr./jun. 1972, p. 307 - 308.

PALLARÉS, Manuel. (Professor espanhol) (Trad. Sylvia Villela de Andrade) "Conduta social e adaptação na idade pré-escolar" RBEP, no 140, out./dez. 1976, p. 540 - 555.

PARAHIM, Orlando. (Médico e professor) "Um inquérito escolar" (publicado inicialmente no Diário de Pernambuco, Recife) RBEP, no 97, jan./mar. 1965, p. 148 - 149.

PINHEIRO, Lúcia Marques. (Coordenadora da Divisão de Aperfeiçoamento do Magistério do Centro Brasileiro de Pesquisas Educacionais, INEP, MEC) "Bases para a reformulação de currículos e programas do ensino fundamental" RBEP, no 125, jan./mar. 1972, p. 10 31.

PIRES, Nise. (Pesquisadora do INEP, Chefe da Equipe do Ensino Primário e Médio do Serviço de Assistência Técnica) “Educação Fundamental” RBEP, no 117, jan./mar. 1970, p. $63-73$.

PIRES, Nise. “Objetivos da educação fundamental” RBEP, no 123, jul./set. 1971, p. 10 - 24. QUEIROZ, Maria Isaura Pereira de. (Do Departamento de Sociologia da Faculdade de Filosofia, Ciências e Letras da Univ. de São Paulo) "Infância e adolescência as favelas brasileiras" RBEP, no117, jan./mar. 1970, p. 35 - 49.

RACHID, Cora Bastos de Freitas. (Técnica de Educação do Ministério da Educação e Cultura) "Habilitações profissionais da área terciária”, RBEP, nº 125, jan./mar. 1972, p. 97 $-109$

REIS, Sólon Borges dos. (Professor, deputado estadual e diretor-superintendente do CPP) (Inicialmente publicado no Correio Paulistano, São Paulo). "Educação moral e cívica na escola secundária" RBEP, no 57, jan./mar. 1955, p. 176 - 178.

RENAULT, Abgar. (Professor da Universidade de Minas Gerais) "A crise do ensino" RBEP, no 50, abr./jun. 1953, p. 3 - 19.

RENAULT, Abgar. (publicado inicialmente no "Mensageiro Rural", Minas Gerais) "A professora rural e o cumprimento de sua missão", o texto é um discurso que foi proferido pelo paraninfo da $2^{\underline{a}}$ turma da Escola Normal Rural "A. S. Azevedo", de Minas Gerais, RBEP, no 60, out./dez. 1955, p. 235 - 243.

RENAULT, Abgar. (publicado inicialmente no Boletim da CBAI, Rio) "Cultura técnica como fator de dinamização da cultura geral" RBEP, nº 56, out./dez. 1954, p. 203 - 207.

ROSAS, Paulo. (Diretor do Instituto de Psicologia do Trabalho. Chefe da Divisão de Psicologia do Instituto de Ciências do Homem da Universidade Federal de Pernambuco) “Exame psicológico de candidatas ao magistério primário de Maceió", RBEP, no 107, 


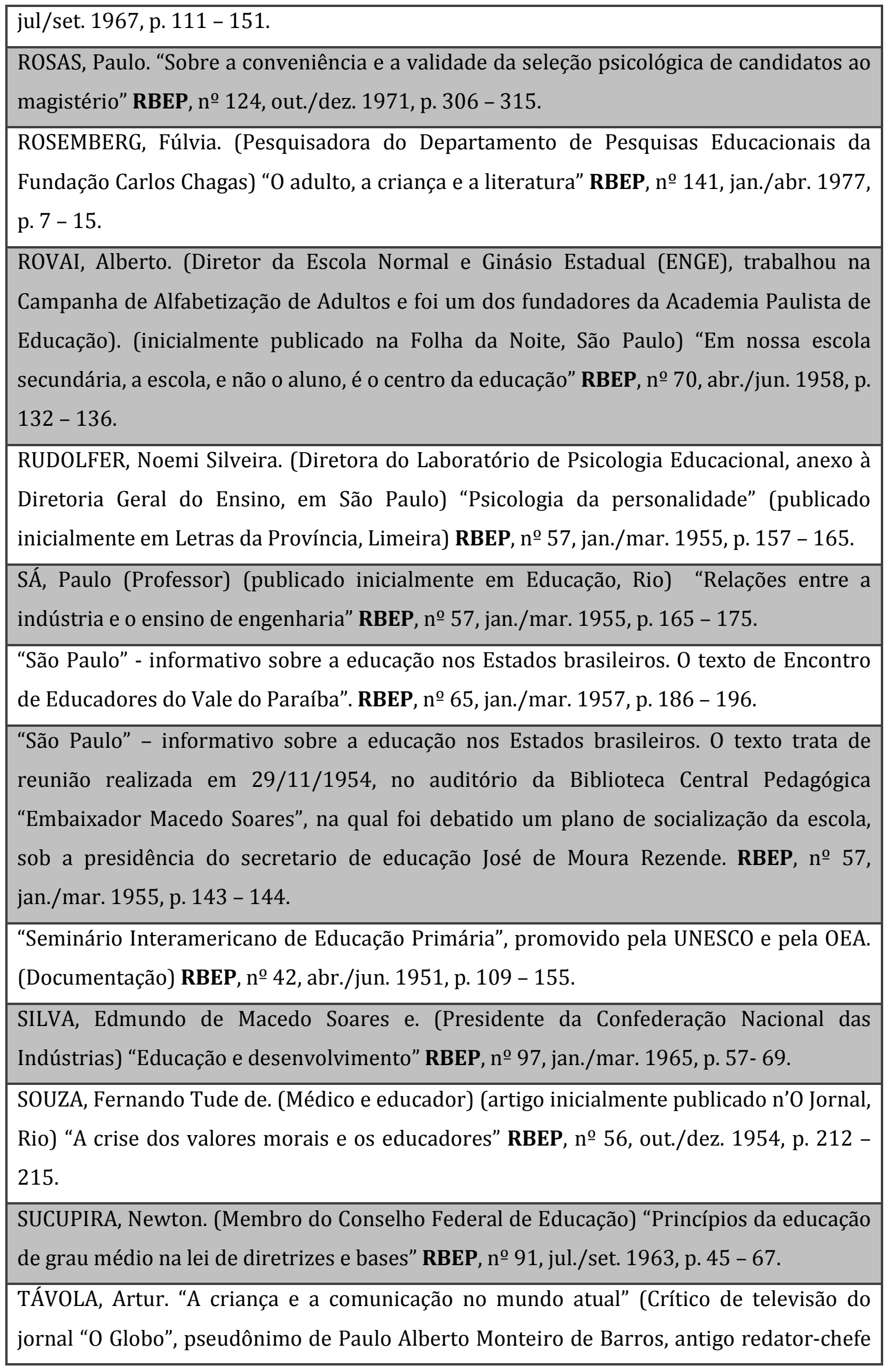




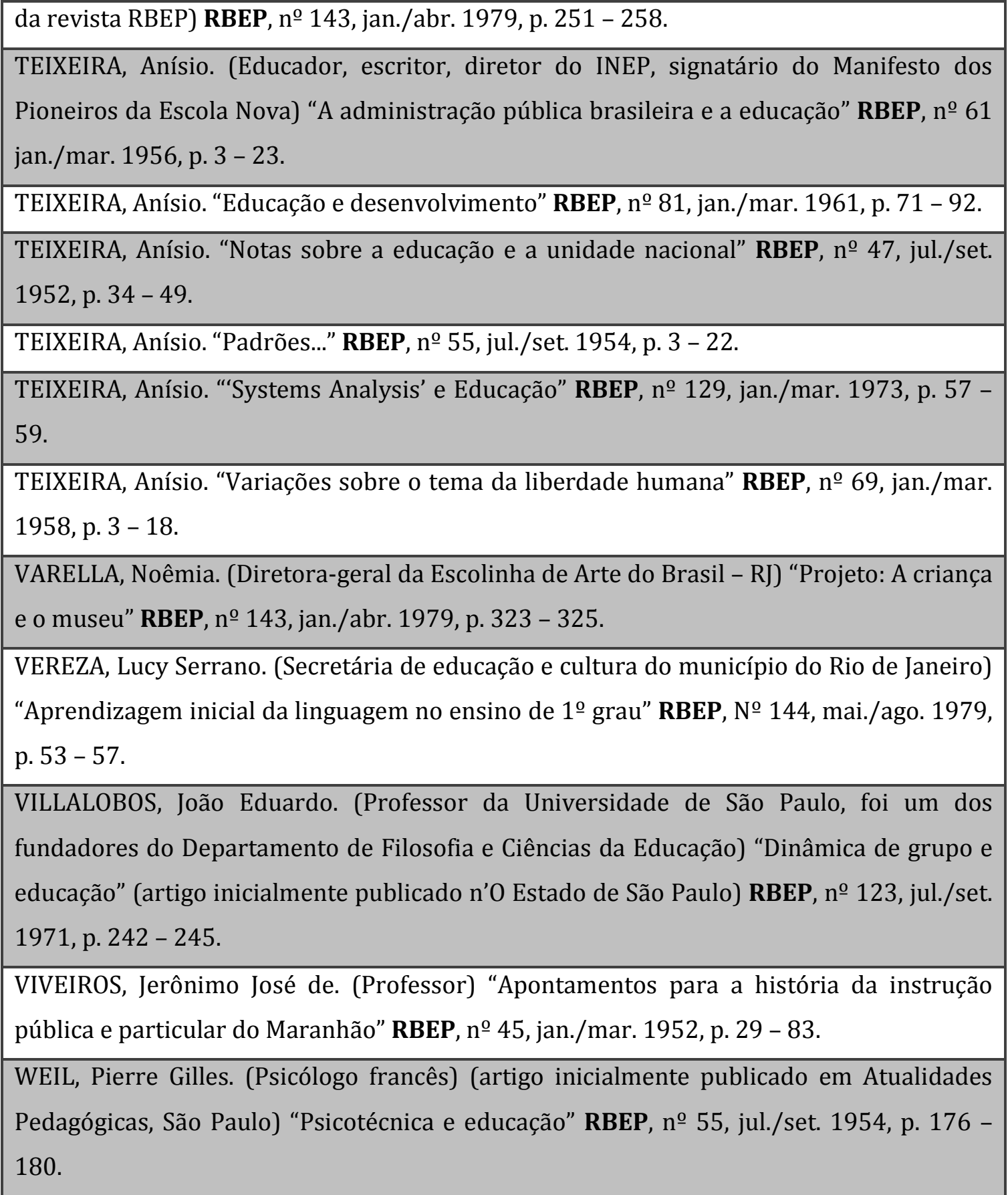




\section{REVISTA DO PROFESSOR (RP) ${ }^{19}$}

A Revista do Professor (RP), órgão informativo do Centro do Professorado Paulista (CPP) constitui um periódico destinado aos professores na rede pública de ensino do Estado de São Paulo. Tal associação docente foi criada em 1930 com o objetivo de defender os interesses da categoria. Durante o processo de estruturação do CPP, com o objetivo de conquistar a legitimidade necessária para afirma-se enquanto representante do professorado, foi produzido um discurso que defendia a "necessidade da união dos professores em torno de uma associação que, como porta-voz da categoria, expressasse suas aspirações e defendesse seus direitos" (CATANI et al, 1997a, p. 85). O referido discurso passou a ter uma privilegiada instância de divulgação com a criação da Revista do Professor, que era distribuída gratuitamente aos sócios do CPP. Criada em 1934, teve sua publicação interrompida entre 1939 e 1949, e foi encerrada 1965. A associação foi dirigida por Sud Mennucci entre 1933 e 1948 (ano de sua morte), a partir de 1956 até 1997, quem a dirigiu foi Sólon Borges dos Reis, ambos considerados "grandes líderes" da associação. Entre 1948 e 1956, a entidade teve diversos presidentes, que não conseguiram se reeleger, diferentemente daqueles citados. Anteriormente ao referido periódico, o CPP publicou o Boletim do Professor. Em 1965, o jornal O professor substituiu a publicação da Revista do Professor. O 1975 o jornal passou a ser editado com o título de Jornal dos Professores. A partir de 1949, na segunda fase da revista, sua periodicidade passou a ser irregular. Neste ano foram publicados somente dois números. Ela foi editada trimestralmente entre $1950 \mathrm{e}$ agosto de 1957 e mensalmente de agosto de 1957 a setembro de 1963, no entanto, nessa época sua periodicidade foi irregular. A regularidade na publicação só foi alcançada em 1960. Nos dois últimos anos de publicação, 1964 e 1965, foram editados somente três exemplares da revista (VICENTINI, 1997).

\footnotetext{
19 As informações sobre o ciclo de vida da Revista do Professor podem ser encontradas nos trabalhos realizados por Paula Perin Vicentini: Um estudo sobre o CPP (Centro do Professorado Paulista): profissão docente e organização do magistério (1930 - 1964), dissertação de mestrado, FEUSP, 1997 e Imagens e representações de professores na história da profissão docente no Brasil (1933-1963), tese de doutorado, FEUSP, 2002.
} 
Considerando-se o ciclo de vida da Revista do Professor, Vicentini defende que é possível identificar as marcas do personalismo das lideranças do CPP em fases do periódico. A primeira fase, período que durou entre 1934 e 1939, sob o comando de Sud Mennucci, foi marcada pela constituição de uma rede de serviços, que funciona ainda hoje, oferecendo aos associados atividades recreativas, atendimento médico e assessoria jurídica. Os artigos nessa ocasião exaltavam a nobreza da profissão docente e a dedicação do magistério paulista, retratando o trabalho do professor como um sacerdócio. Contudo, a revista dedicava pouco espaço para tratar das reivindicações salariais da categoria, reconhecendo que aumento salarial dependia do orçamento público. Nessa época o magistério primário contava com cerca de 20.000 professores, no entanto, apenas 6.000 eram associados ao CPP. O número de associados sofreu considerável expansão na gestão de Sólon Borges dos Reis, que se elegeu deputado várias vezes pelo Partido Democrata Cristão (PDC), passando de 14.000 sócios em 1956 a 40.000 em 1964 . O patrimônio da entidade também foi ampliado com a criação de sedes regionais no interior do Estado. $\mathrm{O}$ discurso veiculado pela Revista do Professor tornou-se bastante diferente daquele expresso na fase anterior: com o desenvolvimento do populismo no Brasil, a desvalorização do magistério cada vez mais presente e o surto inflacionário desencadeado no governo Juscelino Kubitschek, "o CPP alterou completamente a forma de encaminhar as reivindicações da categoria, empregando estratégias mais agressivas mediante a organização de campanhas salariais, nas quais havia a mobilização do professorado em atos públicos e que culminaram na realização da primeira greve do magistério paulista em 1963" (VICENTINI, 2002, p. 108).

Segundo Paula Vicentini (2002), durante o período de circulação o periódico realizou o que Pierre Bourdieu denominou "hagiografia do campo", publicando biografias de professores aposentados ou falecidos, tidos como exemplos para a categoria. Além de descrições da carreira de professores em atividade, enfocando suas qualidades profissionais e morais. Os professores também eram retratados através de fotografias e ilustrações. Quando ao caráter hagiográfico, a Revista do Professor esforçava-se por construir uma base comum de personalidades e valores a serem cultuados pelo grupo como um todo, operando a constituição da "memória coletiva" do magistério. Vicentini recorre a Michel Pollak para afirmar que a "memória coletiva" reforça o sentimento de pertencimento ao grupo e diferencia o mesmo dos demais, "há uma espécie de 'negociação para conciliar 
memória coletiva e memórias individuais' que torna fundamental o estudo sobre 'os processos e os atores que intervêm no trabalho de constituição e de formalização das memórias"” (op. cit., p. 109) A Revista do Professor, órgão informativo de uma associação docente, apresenta características bastante distintas daquelas apresentadas pela Revista Brasileira de Estudos Pedagógicos, periódico de caráter oficial. A RP traz artigos curtos, possui poucas páginas e é muito rica em fotografias, ilustrações e propagandas, a maioria dessas referentes a roupas, material escolar e alimentos. A seguir, segue uma listagem com os 79 textos selecionados na Revista do Professor para o desenvolvimento do presente estudo. Acompanhada da referência do artigo, há uma breve informação biográfica sobre o autor de cada um deles. Tais informações reunidas neste trabalho foram localizadas na própria revista e mediante pesquisas na internet.

\section{Listagem dos artigos selecionados na Revista do Professor}

AGUIAR, José Dias de. (Professor primário - Palmital, SP) “O castigo físico” RP, jan./1960, p. 31- 32.

ALVES, F. Rodrigues. (Professor da Escola Normal de Natal, RN) "Qualidades positivas do bom mestre" RP, jan./1959 p. 25.

ALVES FILHO, Ernesto. (Professor e jornalista - artigo inicialmente publicado no "Correio Popular", de Campinas) “Elas, as primeiras professoras” RP, dez./1959, p. 8. ARAUJO, Olivio de. (Professor - Votuporanga, SP) "Instrução moral e cívica” RP, Jan./Mar., 1963, p. 32.

BARIONI, Walther. SP (Professor, jornalista e poeta) "O ensino normal de São Paulo e a Lei de Diretrizes e Bases" RP, Abr./Jun., 1963, p. 7 - 8.

BERNARDES, Joaquim M. (Professor - São Paulo, SP) “Conceituação sociológica da educação" RP, Jul./Set., 1961, p. 4 - 5.

BERRUTTI, José (Educador argentino) “Decálogo do professor” RP, dez./1959, p. 28. BIAGIONI, Mário (Professor primário); CRUZ, Osmar Martins (Diretor de Grupo Escolar); VÁLLIO, José Marques (Inspetor Escolar). “A escola primária e os exames finais" RP, mar./1959, p. $10-12$.

BIAGIONI, Mário; CRUZ, Osmar Martins; VÁLLIO, José Marques. "A escola primária e os exames finais" RP, mai./1959, p. $19-22$.

CAMARGO, Valdomiro Pires. (Educador e advogado) "As instituições como fatores do 


\begin{tabular}{|c|}
\hline $\begin{array}{l}\text { CAMARGO, Acácio de Vasconcelos. (Professor - Itu, SP) “A missão do professor” RP, no 57, } \\
\text { ago./set. 1960, p. } 15 .\end{array}$ \\
\hline $\begin{array}{l}\text { CAMORIM, Botyra. (Professora e escritora - Mogi das Cruzes, SP) "Privilégio de ser } \\
\text { professor" RP, jan./mar. 1963, p. } 30 \text {. }\end{array}$ \\
\hline $\begin{array}{l}\text { CAMPOS, João José da Silveira. (Professor e inspetor escolar - Laranjal Paulista, SP) } \\
\text { "Filosofia da administração escolar" RP, mar./1959, p. } 6 \text {. }\end{array}$ \\
\hline $\begin{array}{l}\text { CAMPOS, João José da Silveira. "Formação da consciência econômica e profissional" RP, } \\
\text { abr./1960, p. } 6 .\end{array}$ \\
\hline $\begin{array}{l}\text { COSTA, José Américo da. (Professor - São João del Rei, MG) "Análise sintática" RP, } \\
\text { jan./1959, p. } 27-28 .\end{array}$ \\
\hline $\begin{array}{l}\text { COSTA, Rubem. (Professor e escritor - Amparo, SP) “Um sinal esquecido" RP, ago.set. } \\
\text { 1960, p. } 5 \text { - } 6 \text {. }\end{array}$ \\
\hline $\begin{array}{l}\text { DORIN, Lannoy. (Professor e escritor - Ituverava, SP) “Acerca das secções 'A', 'B' e 'C'” RP, } \\
\text { ago./set. 1962, p. } 25 \text { - } 27 \text {. }\end{array}$ \\
\hline $\begin{array}{l}\text { FARIA NETTO, F. de. (Professor - São Paulo, SP) “A educação bandeirística” RP, } \\
\text { out./1960, p. } 28 \text { - } 29 \text {. }\end{array}$ \\
\hline $\begin{array}{l}\text { FLORENTINO, Rosalvo. (Professor e jornalista - São Paulo, SP) "Crises no mundo } \\
\text { contemporâneo" RP, ago./set. 1960, p. } 25 \text {. }\end{array}$ \\
\hline $\begin{array}{l}\text { FRANCINI, Walter Augusto. (Professor e escritor - Porto Ferreira, SP) “Uma sugestão" RP, } \\
\text { mai./jun., 1961, p. } 21 .\end{array}$ \\
\hline $\begin{array}{l}\text { GIONGO, Alberto Bruno (Professor da Escola Artesanal de Taquaritinga, SP) “A orientação } \\
\text { educacional e o professor" RP, jul./1959, p. } 29 .\end{array}$ \\
\hline $\begin{array}{l}\text { GIÚDICE, Alberto Ferreira. (Diretor do Grupo Escolar "Prof. Benedito Ferraz Bueno", } \\
\text { Mococa) “Caráter” RP, no 40, jul./1958, p. } 11 .\end{array}$ \\
\hline GIÚDICE, Alberto Ferreira. “Educação” RP, set./1959, p. 20 \\
\hline $\begin{array}{l}\text { GIÚDICE, Alberto Ferreira. "Conseqüências de uma industrialização inesperada" RP, } \\
\text { out./nov. 1959, p. } 8 .\end{array}$ \\
\hline GIÚDICE, Alberto Ferreira. “Uma das falhas do brasileiro” RP, jun./1960, p. 29. \\
\hline GIÚDICE, Alberto Ferreira. "Ponto alto que se tornou ponto baixo" RP, jul./1960, p. 1 \\
\hline $\begin{array}{l}\text { GONZALEZ, Oswaldo Guérner. (Professor - São Paulo, SP) "Relações humanas" RP, } \\
\text { ago./set. 1960, p. } 37 \text {. }\end{array}$ \\
\hline GRIGOLON, João. (Professor - São José do Rio Pardo, SP) “Castigos físicos: o bom exe \\
\hline
\end{tabular}




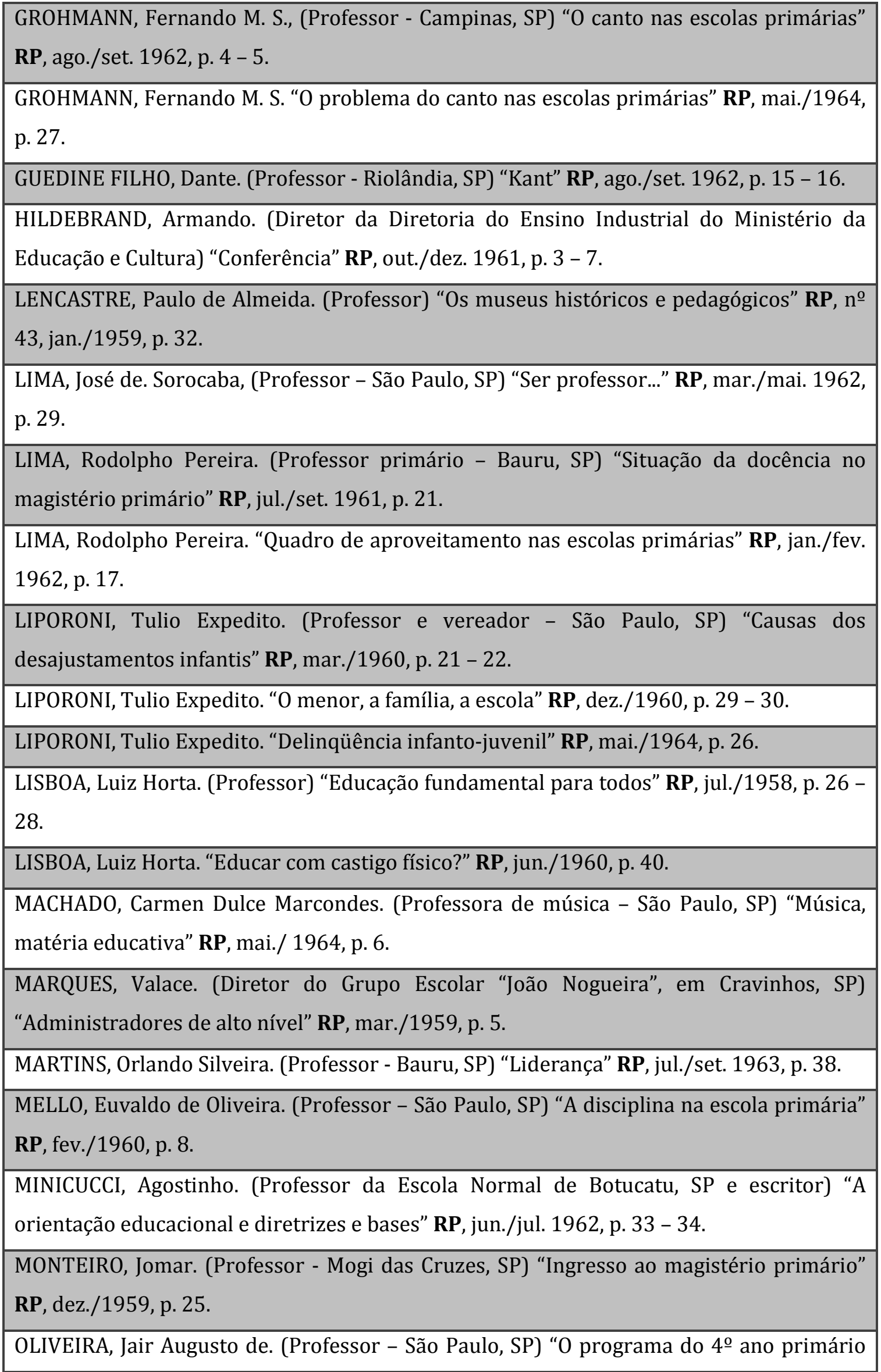




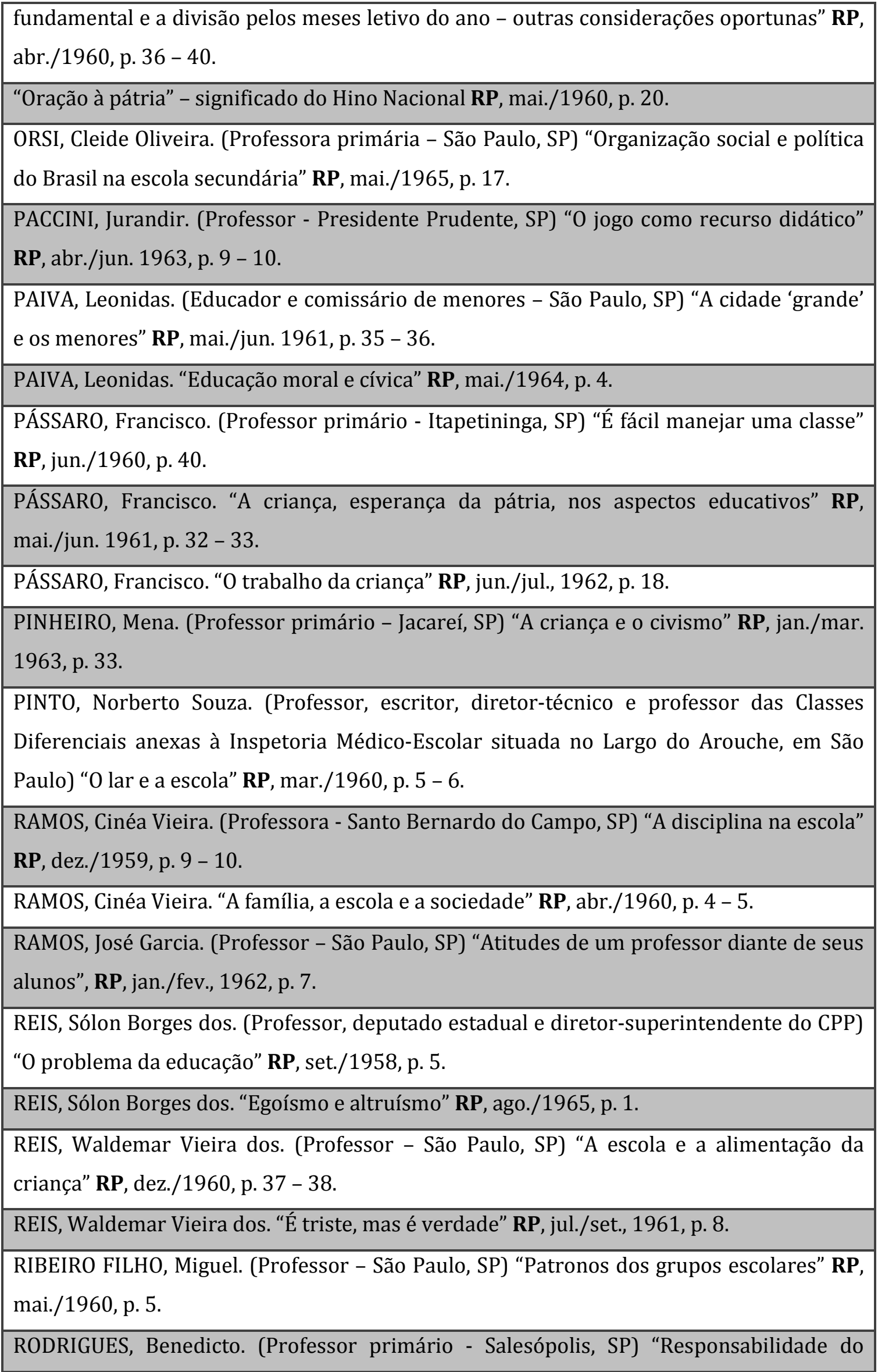




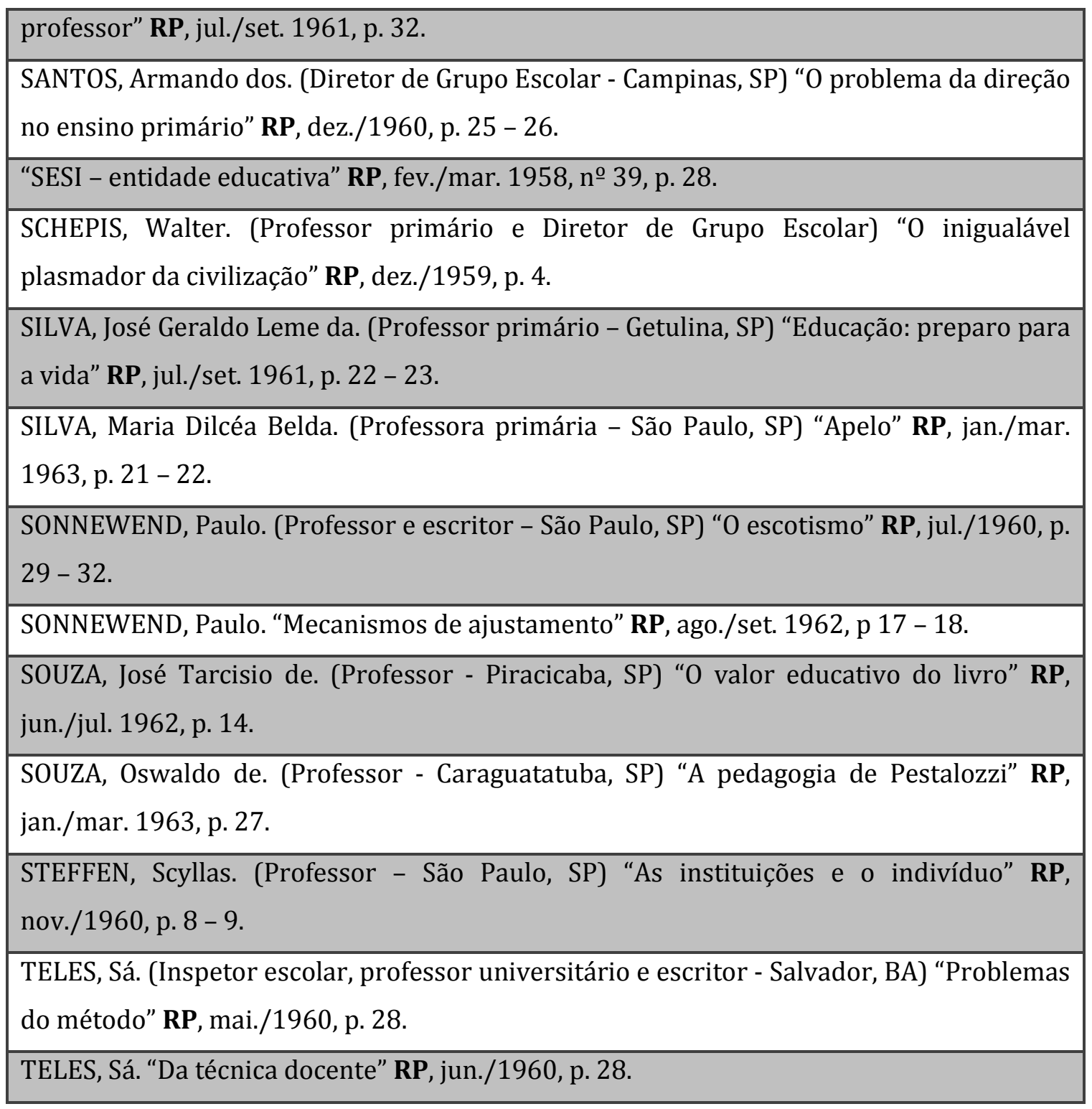




\section{$\underline{\text { OS MANUAIS PEDAGÓGICOS }}^{20}$}

A docência, que teve sua gênese nas congregações religiosas, durante seu processo de profissionalização passou por algumas fases que a caracterizaram. Inicialmente, há a obrigatoriedade, por parte do Estado, da licença para exercer a atividade. Outra característica é o exercício da profissão em tempo integral, ou seja, pessoas que não lecionavam como atividade secundária, mas sim como ocupação principal. $\mathrm{O}$ surgimento das instituições de formação de professores e as associações docentes completam o quadro que configura tal processo. As escolas normais, mais do que formar professores, produzem a profissão docente (NÓVOA, 1995). No Brasil, estas instituições começaram a ser construídas na segunda metade do século XIX. De acordo com António Nóvoa (1996), "as escolas normais constituem o recinto adequado para disciplinar os docentes, transformados em agentes do projeto social e político da modernidade: os discursos produzidos nesta instituição edificam um modelo de professor que mistura as 'antigas' referências religiosas com o 'novo' papel de servidores do Estado". (op. cit., p. 3) Os dispositivos de controle dos docentes, em especial das mulheres, não atuam apenas sobre os aspectos profissionais, mas também são estendidos às dimensões privadas. $\mathrm{O}$ corpo e a vida das professoras primárias tornam-se objeto de controle e de vigilância. Um contrato de trabalho dos Estados Unidos, de 1923, evidencia tal procedimento. "1. Não se casar durante a duração do contrato. 2. Não ser acompanhada de um homem.(...) 8. Não se vestir com cores vivas. 9. Não tingir os cabelos, em nenhuma circunstância. 10. Se vestir sempre com saiote e saia. 11. Não usar saias cinco centímetros acima do tornozelo.”(APPLE, 1988, p. 74 apud NÓVOA, 1996, p. 9)

De acordo com Nóvoa, este modelo difundiu-se durante várias décadas, assumindo formas mais burocráticas e técnicas de controle. A forma como os modos de vestir-se e o comportamento moral das mulheres são controlados evidencia que as noções de pureza e de moralidade foram tornando-se símbolos do trabalho docente feminino. Esta imagem das docentes acaba por constituir as representações acerca da profissão. Tal processo de

\footnotetext{
20 Um pormenorizado estudo acerca dos manuais de formação de professores foi realizado por Vivian Batista da Silva. Trata-se da tese de doutorado intitulada Saberes em viagem nos manuais pedagógicos: construções da escola em Portugal e no Brasil (1870-1970), FEUSP, 2006. Dentre os 14 títulos examinados neste trabalho, 10 podem ser encontrados na listagem destes livros publicados no Brasil que foi elaborada pela autora.
} 
formação e de inculcação moral por que passam as mulheres para tornarem-se professoras produzem uma certa uniformidade em relação à categoria profissional, sendo que todas acabam por incorporar um mesmo habitus professoral, ou seja, um modo de ser docente que se expressa em aspectos da aparência física, através da postura, das roupas, da maneira de falar. Segundo Pierre Bourdieu (1981), o habitus consiste em disposições incorporadas que estão na origem da ação das pessoas e fazem que elas ajam "sem pensar". A respeito da homogeneidade da profissão docente, cabe explicitar um discurso pronunciado por Albert Shanker, líder sindical americano, em 1974, transcrito por Nóvoa (1996): “Todos os anos, há 10.000 novos professores que entram no sistema escolar de Nova Iorque. Eles vêm de quase todas as partes. Eles representam toda sorte de religiões, raças, de filiações políticas e mesmo de formações profissionais. Mas o que é bastante curioso é que, depois de três semanas em classe, não se distingue mais um do outro" (CUBAN, 1983 apud NÓVOA, 1996, p. 10). Se o convívio com outros professores acentua ainda mais a maneira que cada sujeito apresenta de portar-se, de falar e de agir, que são fruto de representações mentais que cada um tem daquilo que considera ser a "realidade", os livros que são utilizados nos cursos de formação, os manuais pedagógicos, reforçam o que consideram ser o comportamento ideal para um docente. Eles definiam as atitudes desejáveis aos professores e aos alunos através do que elogiavam ou censuravam. Por serem dotados de uma linguagem bastante simples, estes eram considerados verdadeiros guias para as jovens estudantes do curso normal. Estes livros, escritos também por aqueles que lecionavam no referido curso, mostravam às alunas como ensinar a criança a ter uma boa higiene, manter uma boa postura, a ser organizada com seus pertences, e também como motivar e comandar a classe, a ter cuidado com o próprio corpo, a vestir-se adequadamente e com asseio. Tal material também era utilizado para difundir práticas de moralização e de uniformização, além de incutir hábitos de higiene.

As prescrições que os manuais apresentam à conduta docente são justificadas pelo fato de as professoras servirem de exemplo aos alunos e ainda é dito que uma boa aparência ajuda no aprendizado das crianças. Conduta esta que teria um importante exemplo dentro da sala de aula: a professora. Através do prescrevem para a conduta dos professores, os manuais de didática estão também deixando claro qual comportamento e formação que esperam das crianças, que, de certa maneira, reproduzem os gestos e as atitudes dos seus mestres. No exame realizado nos manuais de didática e metodologia do ensino também foi possível identificar a justificativa das orientações e o discurso sobre a 
moralização a partir dos três eixos referidos anteriormente: cívico, moral e religioso. Alguns livros usam mesmo os três para se dirigirem à questão. Transitando por três décadas de história através dos manuais pedagógicos, foi possível identificar um discurso que visa submeter o futuro professor e, conseqüentemente, os alunos à moralização mediante muitas justificativas, mas, principalmente, justificativas de cunho religioso, cívico ou psicológico, que são diferenciadas entre uma educação voltada para a alma, como os deveres, as obrigações e os direitos e outra voltada para o corpo, o cuidado consigo mesmo e com a comunidade. No que concerne à questão religiosa, foi surpreendente observar a maneira como o discurso cívico está atrelado ao discurso religioso. Diferentemente do caso da França, por exemplo, em que a moral religiosa foi substituída por uma moral laica, no Brasil, elas caminham juntas, por mais que, teoricamente, tenha havido uma separação no plano da legislação.

$\mathrm{O}$ estudo dos manuais pedagógicos se fez pertinente para o desenvolvimento do presente trabalho porque, através do exame dos mesmos, foi possível extrair recomendações quanto à instituição e à permanência de práticas de moralização na escola. Buscou-se compreender, mediante a análise dos referidos livros, a maneira pela qual as referidas práticas eram tratadas nos livros e quais as justificativas utilizadas para o tratamento das mesmas. Quanto à apropriação de tais materiais, sabe-se que eles eram bastante utilizados nos cursos normais e também pelas jovens professoras primárias que estavam no início da carreira. Contudo, não é possível identificar o que saltava das páginas dos livros e passava a fazer parte da cultura escolar. Ainda há outro fator a ser considerado num trabalho desta natureza: a "chave de leitura", termo utilizado por Roger Chartier (1990) ao considerar que a leitura é uma prática e, desta forma, não existe texto sem o suporte que o dá a ler. A esse respeito, o autor afirmou: "daí a necessidade do estudo da leitura reunir duas perspectivas: o estudo da maneira com os textos, e os impressos que lhes servem de suporte, organizam a leitura que deles deve ser feita e, por um lado, a recolha das leituras efectivas, captadas nas confissões individuais ou reconstruídas à escala das comunidades de leitores" (op. cit., p. 123-124). A compreensão da leitura é resultado da forma como o texto é lido: leitura oral, silenciosa, individual, em grupo, etc. Os professores pertencem a uma comunidade de leitores e acredita-se que a leitura dos manuais era feita ora de forma individual, quando estes guiavam o trabalho docente, ora em grupo, quando eles eram utilizados pelas alunas durante as aulas no curso normal. Estes livros constituíram-se como importantes fontes de pesquisa, uma vez que, sendo utilizados 
nas escolas normais, indicavam, em textos bastante prescritivos, os padrões de comportamento que deveriam ser apresentados na vida escolar e fora dela. Eles definiam quais eram as atitudes desejáveis aos professores e aos alunos através do que elogiavam ou censuravam. Por serem dotados de uma linguagem bastante simples, estes eram considerados verdadeiros guias para as jovens estudantes normalistas. De acordo com Silva (2004), tais livros: "instauram maneiras de conceber e viver o magistério, muito presentes desde a formação inicial desse grupo. Esses textos visam a se constituir justamente num primeiro contato das normalistas com os estudos da área ou, em outras palavras, com os saberes educacionais". (op. cit., 175)

Estes livros apresentavam a síntese de vários livros utilizados no campo educacional, relacionada a diversas áreas do conhecimento, como biologia, filosofia, história e psicologia. Escritos também por docentes do referido curso, os manuais mostravam aos educadores como ensinar a criança a ter a manter uma boa postura, a ser organizada com seus pertences, a motivar e a comandar a classe, a ter cuidado consigo mesma, a controlar-se e a conter-se. Desta forma, busca-se perceber o que tais livros diziam sobre as práticas de moralização, como o faziam e de que forma tais prescrições, referentes à conduta pessoal de cada um e aos seus hábitos, precisavam fazer parte das aulas e dos discursos dos docentes. O período delimitado por essa pesquisa, 1948 a 1978, corresponde a uma época em que essas publicações passaram a privilegiar aspectos referentes ao planejamento escolar, aos métodos e às técnicas de ensino, guiando o trabalho dos professores em direção às questões relativas à organização interna da sala de aula. (SILVA, 2006) O critério para a seleção dos manuais foi o grande número de edições que cada publicação apresentou, o que evidencia que os livros foram bastante utilizados na formação de professores no período. Do exame de tal material, foram selecionados trechos que fazem referência às palavras: moral e moralização, e também, uniformização e padronização.

A seguir, segue uma listagem com os 14 títulos dos livros selecionados para o desenvolvimento do presente estudo. Acompanhada da referência do manual pedagógico, há uma breve informação biográfica sobre o autor de cada um deles. Tais informações reunidas neste trabalho foram localizadas nos próprios manuais pedagógicos que, em sua maioria, apresentaram uma pequena nota biográfica sobre os autores, na tese de doutorado de Vivian Batista da Silva (2006) e mediante pesquisas na internet. 


\section{Listagem dos manuais de didática examinados}

D’ÁVILA, Antônio. (Professor de Educação da Escola Normal anexa ao Ginásio Ipiranga (1940), Ex-Diretor do Serviço de Orientação Pedagógica do Departamento de Educação de São Paulo $(1947,1949)$, Assessor Técnico da Divisão de Ensino no SENAI em São Paulo) Práticas Escolares 5ª edição São Paulo: Saraiva, 1949.

FONTOURA, Afro do Amaral. (Professor da Pontifícia Universidade Católica do Rio de Janeiro, da Universidade do Estado do Rio de Janeiro, da Faculdade de Serviço Social do Distrito Federal; Chefe do Departamento de Sociologia da Faculdade de Ciências Sociais; Técnico de Educação; Delegado do Governo junto a várias Escolas Normais; Professor de inúmeros cursos de aperfeiçoamento para professores.) Didática Geral 8ª edição Rio de Janeiro: Aurora, 1965.

FONTOURA, Afro do Amaral. Fundamentos da Educação: Princípios psicológicos e sociais, Elementos de Didática e Administração Escolar 3a edição Rio de Janeiro: Editora Aurora, 1954.

FONTOURA, Afro do Amaral Metodologia do Ensino Primário. 6 ${ }^{\mathrm{a}}$ ed., Rio de Janeiro: Aurora, 1955.

GONÇALVES, Romanda. (Ex-Diretora do Instituto de Educação de Niterói; Ex-professora de Didática Geral e Especial, de Pedagogia da Faculdade Fluminense de Filosofia; Professora de Didática Geral do Instituto de Educação de Niterói; Ex-professora de Didática do Instituto Social da PUC; Ex-professora de Didática Geral do Instituto Social da Pontifícia Universidade Católica; Ex-Orientadora Educacional do Instituto de Educação de Niterói, ex-chefe da Divisão de Pesquisa de Orientação Pedagógica da Secretaria de Educação e Cultura do Estado do Rio de Janeiro; Professora de Didática Geral e de Psicologia Educacional do Instituto de Educação Prof. Ismael Coutinho/ex-Instituto de Educação de Niterói) Didática Geral 13a edição 1ํo volume São Paulo: Freitas Bastos, 1977.

GONÇALVES, Romanda. Didática Geral 12ª edição $2^{2}$ volume São Paulo: Freitas Bastos, 1977.

GONÇALVES, Romanda. Didática Geral 11aㅡ edição $3^{0}$ volume São Paulo: Freitas Bastos, 1977.

GRISI, Rafael. (Professor de Didática na Escola Normal "Caetano de Campos", professor da Universidade Mackenzie, professor da Escola de Comércio "Armando Penteado", no Largo São Francisco, professor de Metodologia do Ensino Secundário do Instituto de Educação, 
professor de História e Filosofia da Educação da Faculdade de Filosofia, Ciências e Letras da Universidade de São Paulo, diretor geral da Secretaria da Educação de São Paulo para implantar sistemas de alfabetização, secretário da educação no Espírito Santo.) Didática Mínima 3 ${ }^{a}$ edição São Paulo: Editora do Brasil, 1956.

LOURENÇO FILHO, M. B. (Professor emérito da Universidade do Brasil, professor da Escola Normal Primária de São Paulo, professor de Psicologia e Pedagogia da Escola Normal de Piracicaba, diretor da Instrução Pública e professor da Escola Normal de Fortaleza, professor da Escola Normal de São Paulo, diretor de gabinete de Francisco Campos (1931), diretor geral do Departamento Nacional de Educação (nomeado por Gustavo Capanema, em 1937), diretor do Instituto Nacional de Estudos Pedagógicos, signatário do Manifesto dos Pioneiros da Escola Nova.) Introdução ao Estudo da Escola Nova 11a edição São Paulo: Melhoramentos, 1965.

MATTOS, Luiz Alves de. (Professor catedrático de Didática Geral e Especial e Diretor do Colégio de Aplicação da Faculdade de Educação da Universidade do Brasil; Ex-catedrático e ex-diretor da Faculdade de Educação da Universidade do Distrito Federal; ex-diretor da Escola Brasileira e da Escola Interamericana de Administração Pública da Fundação Getúlio Vargas.) Sumário de Didática Geral 7ạ edição Rio de Janeiro: Aurora, 1967.

NÉRICI, Imideo Giuseppe. (Professor da Universidade Mackenzie, da Faculdade Municipal de Filosofia, Ciências e Letras de Taubaté, das Faculdades Metropolitanas Unidas, da Faculdade de Filosofia, Ciências e Letras "Oswaldo Cruz", Colégio Estadual e Escola Normal "Dr. Alarico Silveira"; Ex-professor na Faculdade de Filosofia da Universidade do Distrito Federal, membro da Interamerican Society of Psychology.) Ensino Renovado e Fundamental 5aㅡ edição São Paulo: Nobel, 1975.

PENTEADO, José de Arruda. (Professor da UNESP, campus de São José do Rio Preto, professor do Instituto de Artes (IA) da UNESP, campus de São Paulo, foi um dos fundadores do Núcleo de Estudos Freinet.) Didática e Prática de Ensino: uma introdução crítica São Paulo: McGraw-Hill do Brasil, 1979.

PERRACINI, Aldo. (Diretor do Ginásio Vocacional do Liceu Eduardo Prado (LEP), fundador do Colégio Vocacional Luis Antonio Machado.) A Escola Renovada: 10 anos de realizações na renovação do ensino São Paulo: Tabajara, 1972.

QUEIRÓS, Brisolva de Brito. et al (Professora do Instituto de Educação do Distrito Federal; Assistente de Administração escolar e Educação comparada da Faculdade Nacional de Filosofia.) Didática do Ensino Primário: Prática de Ensino 7ạ edição Rio de Janeiro: Conquista, 1960. 
SANTOS, Teobaldo Miranda. (Catedrático de Filosofia da Educação da Universidade Católica, da Faculdade de Filosofia de Santa Úrsula e do Instituto de Educação do Rio de Janeiro; Professor de Pedagogia da Escola Técnica de Assistência Social da Prefeitura do Distrito Federal; Ex-diretor da Escola Normal Oficial de Campos; Ex-catedrático de Prática do Ensino Primário da Univ. do Distrito Federal; Ex-diretor geral do Departamento de Educação Primária e do Departamento de Educação; Técnico-Profissional do Distrito Federal.) Curso de Psicologia e Pedagogia: Manual do Professor Primário. $3^{3}$ ed., São Paulo: Companhia Editora Nacional, 1962.

SANTOS, Teobaldo Miranda. Metodologia do Ensino Primário $5^{a}$ edição São Paulo: Companhia Editora Nacional, 1955.

\section{$\underline{\text { A LEGISLACC̄̃̃O }}$}

O estudo da legislação estadual referente à educação pública no Estado de São Paulo, vigente durante o período contemplado por esse trabalho, é importante para a compreensão das normas que regiam o ensino da época, mas também para percebermos o quanto as leis e os decretos, através das regras que instituíam, pretendiam regular o comportamento dos professores e dos alunos. Até o século XIX, no Brasil, a educação das crianças era ministrada principalmente em casa ou na comunidade, fato denominado como socialização endógena ou socialização primária. Na virada do século XIX para o século $\mathrm{XX}$, a educação das crianças passou a ter um lugar próprio para acontecer: as escolas, e, mais especificamente, os grupos escolares (FARIA FILHO, 2000). A socialização então tornou-se exógena ou secundária. Se no século XIX os tipos de educação ministrados eram múltiplos e diversos, no século XX começou a existir um sistema de ensino unificado, sistematizado, laico, gratuito e obrigatório. Nesse momento o Estado encarregou-se da educação formal, substituindo a Igreja. O poder, nessa época conhecida como "moderna", torna-se exclusividade do Estado, que legitima sua autoridade através de regras, da magnificência da arquitetura dos edifícios, do currículo formal, dos uniformes escolares, da ordenação dos tempos e dos espaços escolares. A legitimação do poder do Estado ocorre através da adoração aos símbolos pátrios - à bandeira, ao hino, fazendo com que a 
interioridade de cada um seja voltada para uma abstração. Enfim, tal legitimidade é construída através de todos os objetos que possam dar visibilidade a algo passa a ser fundamental, mas que é abstrato: a palavra, que passa da forma oral para a escrita. A normatização legal é a principal forma de intervenção do Estado. Acreditava-se que o progresso da nação viria por meio das letras, para tanto, as leis procuravam ordenar o sistema de ensino, uniformizando-o. Daí a importância da legislação em organizar e homogeneizar o ensino. Faria Filho (1998), defende a necessidade de uma mudança na forma de o pesquisador conceber a legislação como objeto e como fonte para a pesquisa histórico-educacional. Concebendo a lei como materialização e como prática de determinado "pensar pedagógico" seria possível perceber pontos de vista até então desconhecidos: "por exemplo, muito mais do que temos pensado, a lei está intimamente ligada a determinadas forma de concepção da escola, concepções estas que são produzidas no interior dos parlamentos ou de alguma outra instância do Estado, mas apropriadas, de maneiras as mais diversas, pelos diferentes sujeitos ligados à produção e à realização da legislação" (op. cit., p. 115). Para o autor, o exame da legislação permite identificar a relação entre o que era recomendado pelas autoridades e as práticas estabelecidas no sistema escolar, isso porque os documentos legislativos são construídos em diálogo com a cultura e a sociedade. Faria Filho recorre a Sérgio Adorno para afirmar a necessidade de uma revisão das formas de compreensão da legislação: "Questões a propósito dos fundamentos sociais que presidem a jurisprudência normativa, ou a respeito das forças de transformação e conservação que atuam sobre o Direito não pareciam seduzir a mentalidade de nossos principais cientistas sociais. Salvo raras exceções muitos aceitavam, sem grandes reservas, que a função do aparelho judiciário era fundamentalmente repressora, que os profissionais da lei, enquanto categoria social, mantinham irrefutáveis compromissos com as estruturas de apropriação econômica e de dominação política, e finalmente, se aceitavam que a ordem jurídica estava formalmente organizada sob inspirações de princípios liberais, seus fins concretos estavam voltados para a 'legalização' dos interesses das classes dominantes" (ADORNO, 1988, p. 20 apud FARIA FILHO, 2003, p. 3).

Segundo Faria Filho, no final do século XIX articularam-se discursos acerca da escolarização da população brasileira, e, principalmente, da infância, que têm grande importância ao longo da história educacional do país. O autor afirma que os produtores desses discursos são os bacharéis, que formam um grupo particular de intelectuais, 
políticos e profissionais. Esses discursos, ao entenderem que a questão da escolarização das camadas mais pobres da sociedade era um problema que deveria ser combatido, inicialmente, pelo "artifício formal" da produção de leis, acabaram por atualizar, no Brasil, toda uma tradição ibérica no que diz respeito ao ato legislativo: "no entanto, nossos sujeitos pretendem fazê-lo fundando uma nova tradição, no momento mesmo em que pretendem fundar o Brasil e propor o caminho único para a ordem, o progresso e a civilização: a educação do povo" (FARIA FILHO, 2003, p. 4). Desta forma, a legislação, ao ordenar o sistema de ensino, também proporcionava a "civilização" do povo, mediante a educação escolar. Através dos dispositivos legais, articulados às outras fontes utilizadas nessa investigação, as revistas pedagógicas e os manuais de didática, busca-se tecer as considerações realizadas sobre o tema de maneira mais segura.

Nesse sentido, através do exame do conteúdo dos documentos legislativos, pretende-se identificar quais determinações foram concebidas com o intuito de ordenar o comportamento dos sujeitos nas escolas e moralizá-los no período compreendido entre os anos de 1948 a 1978. Para tanto, foram examinados regimentos, portarias, decretos, leis, pareceres, e também a Revista Brasileira de Estudos Pedagógicos, que se apresentou como uma fonte rica em legislação, não só no âmbito estadual, mas também na esfera federal. A seguir, segue uma listagem com os títulos dos documentos consultados para o desenvolvimento do presente estudo.

\section{Listagem da legislação consultada}

“Conselho Federal de Educação: Estudos Sociais no Ensino de 1ํGrau” (Documentação) RBEP, no 129, jan./mar. 1973, p. 148 - 152.

"Conselho Federal de Educação: Seleção de pareceres aprovados durante o trimestre". (Documentação) “Espetáculos para menores: critérios atualizados” RBEP, no 95, jul./set. 1964, p. $154-164$.

"Conselho Federal de Educação: Seleção de pareceres aprovados durante o trimestre". (Documentação) “Educação moral e cívica - Parecer no 136/64, C.E.P. e M., aprov. em 5-61964". RBEP, no 95, jul./set. 1964, p. 116 - 139.

Decreto no 38.538, de 29 de maio de 1961. Regimento Interno dos Estabelecimentos de Ensino Secundário e Normal do Estado de São Paulo.

Lei no 4.024, de 20 de dezembro de 1961. Fixa as Diretrizes e Bases da Educação 


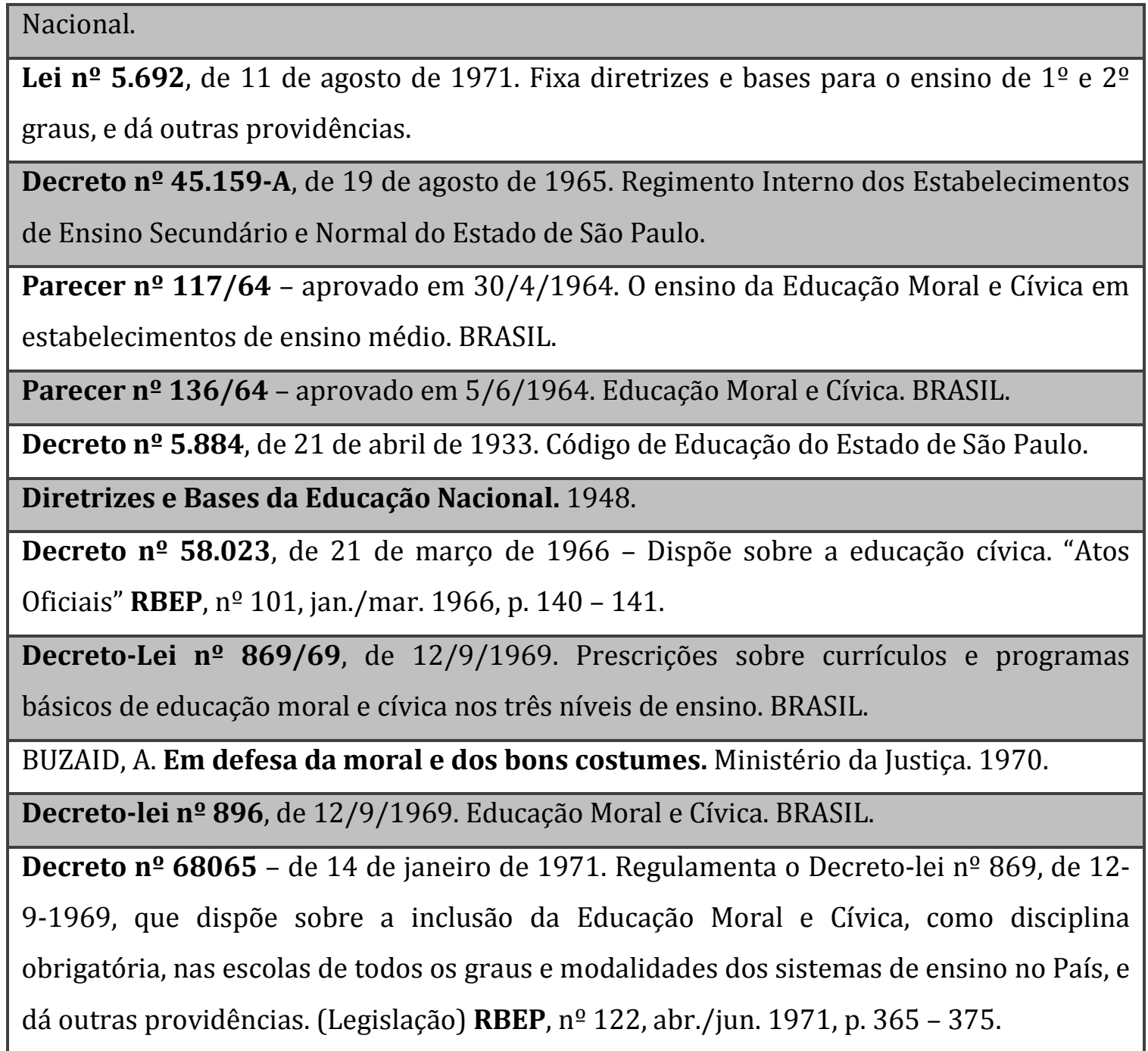




\section{Capítulo 1}

\section{ENTRE A FORMAÇÃO DA VONTADE E A CONTENÇÃO DE SI PRÓPRIO: A FORMAÇÃO MORAL NO ÂMBITO DO AUTOGOVERNO}

“C'est plutôt première par la naissance et par l'excellence que le Dieu constitue l'âme, pour qu'elle puisse commander au corps et le garder sous dépendance"

Platão

Platão (428 - 348 a.C.), em um de seus últimos diálogos ${ }^{21}$, tratou da dicotomia existente entre o corpo e a consciência. Acreditava que a alma seria composta de duas partes: uma superior ("alma intelectiva") e outra inferior ("alma do corpo"). Esta última, considerada irracional, seria dividida, por sua vez, em outras duas partes: a "irascível", impulsiva, localizada no peito e a "concupiscível", localizada no ventre e voltada para os desejos materiais e sexuais. Segundo o filósofo, todo o drama dos homens consistiria na tentativa de fazer com que a alma superior dominasse a inferior. Caso a alma superior não soubesse controlar os desejos e as paixões, o homem permaneceria incapaz de apresentar um comportamento moral adequado. No século 3 a.C. Platão já se preocupava com o comportamento moral dos indivíduos, mesmo não sendo da mesma maneira que as pessoas se preocupavam na metade do século XX. Mas tratava-se, também, de chamar a atenção para a inserção da razão na necessidade, o que talvez pudesse ser traduzido pela pergunta: como o homem seria capaz de dominar as suas paixões e controlar os seus impulsos e os seus desejos? Tanto o corpo quanto a alma teriam partes mortais e imortais. No sentido etimológico da palavra, paixão significa padecer, levar ao sofrimento. As paixões ocupariam a "parte mortal" da alma: agitadas, irracionais, aterrorizantes. Todas as partes da alma seriam estabelecidas no corpo de modo que cada função pudesse ser plenamente exercida e que um equilíbrio fosse possível. O corpo então seria o resultado da organização de um conjunto de "lugares da alma": "il en est à la fois une résultante car sa structure

\footnotetext{
${ }^{21}$ PLATON, Timée, Paris: GF-Flammarion, 1996, p. $182-184$.
} 
intime est commandée par celle de l'âme, et un moyen car il reste tributaire de son commandement : c'est l'âme qui dans tous les cas domine les corps". (LÉVINE, É.; TOUBOUL, P., 2002, p. 179 - grifos meus) Deste modo, a alma domina o corpo e é por esse motivo que o termo alma, empregado neste trabalho, é entendido como o elemento que constitui o indivíduo, domina o corpo e comanda as ações humanas, daí a necessidade de controlá-la. Uma das questões, o controle das paixões, que ocupou Platão, e tantos outros pensadores, atravessou os séculos e continua pertinente. Isto porque a questão do controle dos instintos está intimamente relacionada à manutenção da sociedade - e, no limite, à permanência da espécie humana. É possível notar que as práticas de moralização podem ser entendidas como maneiras empregadas para exercer o controle da alma dos indivíduos. E de que forma isso seria possível? Tendo acesso ao que há de mais íntimo nas pessoas, à sua subjetividade, e criando nela uma necessidade. Essa necessidade geraria então uma obrigação e para obedecê-la o corpo receberia um comando e o transformaria em ação, em gestos e em palavras.

Durante a realização deste estudo, foi possível notar que quando os autores dos manuais pedagógicos e dos periódicos educacionais referiam-se à moralização, era especialmente à alma, à subjetividade dos indivíduos que eles se dirigiam. $\mathrm{O}$ artigo escrito pelo professor Oswaldo de Souza ${ }^{22}$, publicado na RP em 1963, evidencia essa idéia. A propósito da pedagogia de Pestalozzi, ele dizia que a moralidade "nivela-se à Religião, isto é, a Religião equivale exatamente, à Moralidade Humana, do ponto de vista da idéia. Na teoria da instrução humana, deve prevalecer a educação da força moral da vontade. A instrução poderá se desenvolver a partir de dentro. O que interessa é o interior - a alma humana, e não o trabalho exterior em si mesmo". (p. 28 - grifos meus) Ao longo do exame das fontes consultadas nesta pesquisa, foi possível perceber que a idéia do "controle da alma" das pessoas estaria no cerne da questão feita inicialmente: como estiveram presentes as práticas e a representações de moralização na escola pública paulista? No entanto, o termo empregado aqui permeia e orienta os três discursos que estiveram, com freqüência, associados a tais práticas. São eles: o religioso, o cívico e o psicológico. Esses três discursos têm em comum a necessidade de pretender formar a vontade nos indivíduos. A vontade, encarnando o objeto da educação moral por excelência, representa o centro de

\footnotetext{
${ }^{22}$ SOUZA, Oswaldo de. “A pedagogia de Pestalozzi”, RP, Jan./Mar., 1963, p. 27.
} 
equilíbrio que rege conjuntamente as esferas individuais, sociais e coletivas. Ou seja, para que a educação moral seja inculcada nas pessoas e transformada em prática, é preciso que as pessoas aprendam "a querer" e controlem os seus desejos instintivos. Na infância, a formação da vontade incutiria em cada indivíduo a possibilidade de fazer esforços, diante da necessidade, sem que as dificuldades os abalassem. Homens úteis ao Estado ou tementes a Deus, ou as duas coisas - como será visto nos capítulos seguintes - não seriam formados sem que acreditassem que o esforço, o trabalho e o sacrifício são obrigações suas. Deste modo, a formação da vontade levaria ao governo de si mesmo. De acordo com Patrick Berthier (2006), somente quando as crianças adquirissem o hábito de obedecer aos outros é que elas tornar-se-iam capazes de obedecer, mais tarde, à própria razão. Nas palavras do autor " $d$ ' abord apprendre à obéir, presque intransitivement, afin de pouvoir en son temps, s'obéir à soi-même" (op. cit., p. 17). Obedecer-se a si mesmo carecia de uma formação, de moralização, que teria como ponto de partida a obediência como exercício da vontade. Pensando no caso brasileiro, a propósito dessa questão, não há como resistir às palavras de Sampaio Dória quando este era o diretor da instrução pública do Estado de São Paulo, no início dos anos de 1920, e via-se diante de um ensino primário que estava em uma situação altamente deficitária (AZANHA, 1987). Ele dizia: "sempre que penso na realização prática dos princípios democráticos, uma dúvida, uma quase descrença, me assalta o espírito, diante do espetáculo doloroso da ignorância popular. Como organizar-se, por si mesmo, politicamente, um povo que não sabe ler, não sabe escrever, não sabe contar? Se o povo não souber o que quer, como há de querer o que deve? Governos populares, sem cultura, viverão morrendo na sua própria incultura" (DÓRIA, 1923 apud AZANHA, 1987, p. 29 - grifos meus). Ensinar a ler, a escrever e a contar era preciso, mas ensinar a querer também. Principalmente durante o período de expansão das oportunidades de educação pública, o autogoverno era fundamental para que o sistema de ensino pudesse expandir-se e atender, não só muitos alunos ao mesmo tempo, mas também crianças das mais diversas origens sócio-econômicas. O controle da alma era empreendido ao longo do processo de formação escolar tanto dos alunos, quanto dos professores primários. Se aos alunos era preciso ensinar a obedecer - aos professores, aos mais velhos, às leis e a si próprios, a querer trabalhar e, principalmente, a desenvolver a disposição para o trabalho, aos docentes era preciso ensinar a ser um tipo de pessoa, tão obediente quanto os alunos, que fosse a própria encarnação das virtudes morais e que se submetesse às condições de trabalho que lhes fossem apresentadas, por mais difíceis que elas pudessem ser, encarando, 
com resignação, a sua profissão como uma missão e trazendo "nos lábios, um sorriso amigo às suas crianças...”23 (REIS, 1960, p. 38). Desta forma, tanto os docentes quanto as crianças, antes que fossem abandonados a si próprios, precisariam sofrer um processo de conformação moral pois, ao final de tal processo, quando estivessem moralizados, mesmo se estivessem sozinhos, jamais os indivíduos estariam abandonados a si próprios novamente: tendo sua alma sido controlada, os princípios morais funcionariam como uma censura interna que comandaria os seus hábitos, os seus passos, as suas escolhas, as suas decisões e toda a sua vida.

Em artigo publicado na RP em 1961, o educador e comissário de menores Leônidas Paiva $^{24}$ chamava a atenção para as marcas que o abandono moral deixava na alma das crianças. Considerando o problema da criança abandonada como conseqüência da “desorganização familiar", o autor dizia: "a falta de recursos constituirá a causa de muitos desses casos, mas a maioria deles decorre do abandono moral ou da organização da família. Irresponsabilidade moral. (...) A alma da criança órfã ou abandonada fica marcada de muitos complexos de inferioridade, que afloram em atitudes constantes de angústias inibitórias do equilíbrio mental, ou em reações anti-sociais, como surdas vinganças contra o destino adverso..." (p. 36) As reações anti-sociais apresentadas pelas crianças abandonadas física ou moralmente teriam a indisciplina como marca. A disciplina, fazendo desenvolver em cada um a responsabilidade individual, teria por objetivo formar personalidades capazes de regularem a si mesmas, controlando o seu comportamento mediante decisões reflexivas, trazidas à consciência e com o sentimento de responsabilidade. A disciplina, sob a ótica do autogoverno, concebe o problema da educação moral de duas maneiras: o mestre deve intervir sem agir verdadeiramente sobre o aluno; ele deve orientar sua vida no sentido do bem e da verdade, mas evitando determinála, ajudando a criança a mobilizar os seus próprios recursos. No entanto, para que as crianças fossem capazes de mobilizar os seus recursos seria necessário que elas tivessem incorporado a moralidade que as tornaria capazes de engajarem-se no desenvolvimento de um sentido, de uma vocação, de um ideal. Aos poucos, ao longo de seu desenvolvimento e através da educação escolar, as pessoas passariam a adquirir consciência de suas

\footnotetext{
${ }^{23}$ REIS, Waldemar Vieira dos. "A escola e a alimentação da criança”, RP, Dez., 1960, p. 37 - 38.

${ }^{24}$ PAIVA, Leonidas. “A cidade 'grande' e os menores”, RP, Mai./Jun., 1961, p. 35 - 36.
} 
disposições latentes, favorecendo a elaboração e o crescimento de sua conduta moralizada acima de outras tendências, tendo em vista a conquista e a maestria de si mesmos, aprendendo a fazer uso da liberdade, de acordo com os princípios morais.

A recorrência do termo "autogoverno" foi comum não apenas ao longo de todo o período investigado, como também esteve presente em todas as fontes consultadas: nos manuais pedagógicos, nos periódicos educacionais e na legislação. O professor Luiz Horta Lisboa $^{25}$, em artigo publicado na RP em 1958, ressaltava a importância do ensino fundamental para o progresso do país e dizia que "a riqueza das nações é a inteligência do homem” (p. 26). Citando a reforma realizada por de Caetano de Campos em 1891, dizia que a democratização deu ao povo autonomia, a direção de si mesmo e naquele momento seria "urgente então cultivar-lhe o espírito, dar-lhe a elevação moral de que ele precisa, formando o caráter, para que ele possa querer. O povo precisa de self-government. A instrução do povo é sua maior necessidade" (p. 27) Para o governo, tratar-se-ia de um “dever porque ele gerencia o dinheiro público e tem a obrigação de formar escolas e um interesse porque só é independente quem tem o espírito culto e a educação cria, avigora e mantém a posse da liberdade" (p. 28). Lisboa também citou Lourenço Filho a propósito da campanha de educação de adultos dizendo que, por amor às crianças, era preciso educar os adultos. O decreto-lei $\mathbf{n}^{\mathbf{0}} \mathbf{8 6 9}^{26}$, de 12/9/69, que instituiu a educação moral e cívica como disciplina obrigatória, defende, entre as obrigações enunciadas, que a formação moral dos indivíduos seja realizada mediante a autodisciplina e a educação pelo exemplo. Afirmando que é preciso "desejar" a democracia e utilizar a "liberdade com responsabilidade", o decreto sugere o "desenvolvimento de freios internos para a conduta altruística e nobre, disso resultará a autodisciplina. Autodisciplina e prática de autogoverno deverão intensificar-se gradualmente no nível médio" (p. 165 - grifos meus)

Platão, no século 3 a. C., dizia que a alma domina o corpo. Quando há uma intenção de submeter um indivíduo a algo e pretende-se que o indivíduo obedeça, é à sua alma e não ao seu corpo que são dirigidas as práticas. Isto porque o corpo está sujeito ao cansaço, à preguiça, aos apetites e aos desejos, e estes devem ser conduzidos pela alma.

\footnotetext{
${ }^{25}$ LISBOA, Luiz Horta. "Educação fundamental para todos" RP, jul./1958, p. 26 - 28.

26 "Educação moral e cívica no currículo escolar" Decreto-lei $n^{\circ}$ 869, de 12/9/69. Esse decreto inclui a Educação Moral e Cívica como disciplina obrigatória. RBEP, nº 117, jan./mar. 1970, p. 151 - 176.
} 
Segundo Durkheim (1990), a Igreja "inventou" a escola sob uma forma institucional forte - como se fosse um santuário - porque ela tinha um projeto de influência universal sobre as almas. Este modelo escolar pensado pela Igreja seria decorrente de um "projeto de conversão": "la vraie conversion, c'est um mouvement profond par lequel l'âme tout entière, se tournant dans une direction toute nouvelle, change de position, d'assiette et modifie, par suite, son point de vue sur le monde" (op. cit., p. 37) Durkheim escreveu no início do século $\mathrm{XX}$, a fim de elucidar e compreender a constituição da escola laica na Terceira República francesa. Para Claude Lelièvre (2006), a história da escola francesa é aquela de uma longa "laicização" e o projeto de "conversão" que o contém (Deus e a Igreja, ou o Imperador ou ainda a República "una e indivisível”) importa menos do que a forma - aquela do "santuário". Esta escola "santuário" deveria ser um lugar moralmente unido, que envolveria a criança e agiria sobre a sua natureza: não seria apenas um lugar no qual os professores ensinariam a ler, a escrever e a contar, mas seria também um "meio moral", impregnado de certas idéias, sentimentos e que envolveria tanto os professores quanto os alunos. (O modelo escolar criado após a Revolução Francesa segue a lógica de Napoleão, que pretendia criar uma corporação pública - "congregação laica": um organismo visando à realização de um mesmo fim e tendo uma inspiração e uma unidade moral comuns.) Ora, quando se diz às pessoas que busquem a felicidade, a realização pessoal ou mesmo na sugestão acerca da criação de trabalhos que tragam elementos autobiográficos dos indivíduos, a idéia seria oposta a esta: não se trata de discutir aqui a relevância ou avaliar os fundamentos da moral na sociedade, mas sim de perceber de que maneira a escola enquanto instituição recebe a "ordem", ou o "comando", de reproduzi-la e perpetuá-la e o faz da forma como lhe é possível: apropriando-se dela e "escolarizando-a". A importância da escola para a manutenção da sociedade já foi vastamente discutida, inclusive pelo próprio Durkheim (2008). O que se pretende saber neste estudo é como a escola se apropria de algo universal e transforma-o operando com as ferramentas que lhe são próprias: o controle da conduta, os olhares, as recompensas, as músicas, as lições, a leitura, a escrita, os exemplos. Acredita-se, e isso é defendido neste trabalho, que a escola "escolariza" a moral, transforma-a, e a insere na alma das crianças através de sua forma e de suas práticas. Mediante o modelo escolar, a moral buscaria então convergir, operando uma conversão de todos em uma mesma direção. Contudo, é importante observar o quanto a instituição escolar opera, muitas vezes, com dois tipos de moral, imprimindo lógicas antagônicas: uma que defende a formação do cidadão crítico e participativo, ciente de seus 
deveres e de seus direitos, e outra que deve, predominantemente, submetê-lo a regras e a normas de maneira dócil e ordeira. (Hipoteticamente, seria como se, no tocante à participação nas decisões - na democracia - os alunos fossem sempre preparados para algo que só existisse no futuro, fora da escola, nunca no interior do espaço escolar.) O civismo, a caridade, a fraternidade e a compaixão são elementos que deveriam ser cultivados com o objetivo de deslocar a atenção de si próprio e, desta forma, levar o indivíduo a agir em função do outro. O artigo escrito por Sólon Borges dos Reis ${ }^{27}$, intitulado "Egoísmo e altruísmo", publicado na RP em 1965, ilustra a questão. Ele dizia: "na competição íntima que se trava entre a poderosa tendência natural do egoísmo e o esforço moral do altruísmo, está reservado um papel de relevância ao poder da educação. (...) O ideal da educação comunga com o intuito de Kant, ao querer que procurássemos a felicidade alheia como condição também da nossa própria. (...) As projeções patológicas do egoísmo precisam ser contidas pela educação, a fim de que a vida comum, que é absolutamente necessária, seja melhor no plano prático e digna na esfera espiritual”. (p. 3)

Em conflito com a origem social da nova clientela escolar e a necessidade de ajustar essas crianças à sociedade e prepará-las para o trabalho, as escolas elaboraram maneiras de conformar moralmente tanto os alunos quanto os professores, e a psicologia foi uma grande aliada neste processo. Paulo Sonnewend ${ }^{28}$, em artigo intitulado "Mecanismos de ajustamento", publicado na RP em 1962, dizia que os mecanismos de ajustamento eram processos convertidos em hábitos, por meio dos quais indiretamente as pessoas procuravam satisfazer, reduzir ou remover seus motivos frustrados. Publicações relacionadas à higiene mental apontavam para a existência de 65 diferentes mecanismos, com várias denominações, desajustes e comportamentos anti-sociais. Segundo o autor, as deficiências não são apenas reais, podem ser imaginárias, sendo "o desejo de ser apreciado o mais profundo princípio da natureza humana, a aprovação social desempenhará por isso papel de relevo no tocante às deficiências ou defeitos. (...) O importante é a maneira pela qual a pessoa reage aos seus próprios defeitos em função do meio social e não a mera existência deles. Não se pode, pois, concluir que, necessariamente, toda pessoa por apresentar defeitos ou deficiências se sinta inferior. Há muita diferença entre a simples

\footnotetext{
${ }^{27}$ REIS, Sólon Borges dos. "Egoísmo e altruísmo”, RP, Ago., 1965, p. 3.

${ }^{28}$ SONNEWEND, Paulo. "Mecanismos de ajustamento", RP, Ago./Set., 1962, p 17 - 18.
} 
consciência da inferioridade e o modo de senti-la". (p. 17) Com relação à vida familiar, o autor diz que um de seus aspectos típicos "é a sua facilidade própria de gerar conflitos de sentimentos entre as pessoas e, sobretudo, no interior do espírito infantil" (p. 18 - grifos meus). Assim como Sonnewend, outros autores trataram da importância de se conhecer o meio no qual os alunos viviam, já que o mesmo influenciaria na formação moral dos mesmos. A partir dos seis anos de idade, com o início da escolarização primária, as crianças seriam cada vez mais retiradas da influência familiar, pela escola inicialmente, mas também pelas obras extra-escolares e sociais. Por este motivo, era sugerido aos professores que conhecessem a família dos alunos.

Com relação ao meio social, as crianças sofrem diferentes influências no meio rural e no meio urbano. No meio rural as crianças estabeleceriam relações mais próximas com a comunidade e a influência da família seria constante e direta. $\mathrm{O}$ conhecimento das influências que se exercem sobre as crianças no meio rural ajudaria os professores a compreender quais valores seriam partilhados pelos alunos originários deste meio, conduzindo em particular ao desenvolvimento do escrúpulo e da consciência. No meio urbano, em geral a família seria reduzida à relação entre os pais e os filhos. A sociabilidade das crianças na cidade seria realizada entre os vizinhos, no próprio prédio, no quarteirão e muitas vezes na rua na qual viviam. A rua seria um meio atraente para elas, mas perigoso: lá o bem e o mal se misturariam através da pornografia nas bancas de jornal, da "malandragem", dos bares, etc. Esse medo do perigo representado pela influência da rua na formação moral das crianças ficou evidente principalmente nos textos editados a partir dos anos de 1960, por conta do desenvolvimento dos meios de comunicação e da mudança dos valores sociais, que ameaçavam a instituição da família tradicional. Desta forma, o meio social de origem das crianças deveria ser levado em conta, pois poderia consistir em um obstáculo para a transmissão dos valores morais pretendidos pela educação escolar.

O educador Fernando Tude de Souza ${ }^{29}$, em artigo publicado na RBEP em 1954, no qual trata do que considera ser uma crise dos valores morais, defende a "responsabilidade moral" como marca de maturidade, conseqüência da conduta e da autodisciplina desenvolvida nas pessoas pela educação escolar. Ao defender as instituições como "servas do homem", Souza diz que a família, a escola e o governo não são mais importantes do que

${ }^{29}$ SOUZA, Fernando Tude de. "A crise dos valores morais e os educadores" RBEP, no 56, out./dez. 1954, p. $212-215$. 
o povo. A educação escolar deve ensinar o respeito a elas, o que teria como principal função a "autodefesa". Reeditado neste mesmo ano, o manual pedagógico escrito por Afro do Amaral Fontoura, intitulado Fundamentos da Educação, sugeria que, nas escolas, o conselho de monitores, deveria "zelar pela boa disciplina escolar e desenvolver o espírito de autogoverno" (p. 219). Enquanto Souza referia-se à importância da autodisciplina para a manutenção dos valores morais, e Fontoura pregava a necessidade do desenvolvimento do "espírito de autogoverno", o relatório ${ }^{30}$ apresentado na Conferência das Escolas para a Compreensão Internacional, em colaboração com a UNESCO, em 1955, dizia que, pela educação de seus alunos "o professor deve dar o máximo de que é capaz", mas também atribui aos pais a responsabilidade pela formação de seus filhos. Ao citar Herbert Spencer, o relatório indica que a etapa final do desenvolvimento do ser humano é tornar-se pai: "porque criar um filho exige boa dose de autocontrole e formação moral" (p. 150 - grifos meus). Assim como os professores e os alunos, também era necessário que os pais fossem dotados de autocontrole. O professor Wilson Martins ${ }^{31}$, em artigo publicado na RBEP em 1957, sugeria que os alunos participassem na administração da escola, que deveria ser remodelada nas bases de uma comunidade de autogoverno, contando com a coresponsabilidade de mestres e alunos, o que despertaria o sentimento de responsabilidade e disciplina social nas crianças. Assim como Martins, o professor de escola normal Agostinho Minicucci ${ }^{32}$, em artigo publicado na RBEP em 1962, também considerava importante para a formação moral das crianças que as escolas funcionassem através do autogoverno. De acordo com o autor, as escolas não desenvolviam a maturidade cívica, a "qualidade de cidadão" e as atividades que diziam respeito à comunidade: elas conservavam os alunos no papel de dependentes cívicos. Como tudo na escola, a limpeza e a organização eram responsabilidades que cabiam aos professores e aos funcionários, o que criava o hábito da "dependência nos alunos". "Para isso mudar", dizia Minicucci, "é

\footnotetext{
30 "A formação de professores" Trata-se do relatório apresentado na Conferência das Escolas para a Compreensão Internacional, em colaboração com a UNESCO, em 1955. RBEP, nº 64, out./dez. 1956, p. 141 -179 .

${ }^{31}$ MARTINS, Wilson. "O novo Emilio (O que a educação pode esperar das ciências sociais)" RBEP, $n^{\circ} 66$, abr./jun. 1957, p. $125-142$.

${ }^{32}$ MINICUCCI, Agostinho. (Correio do SENAC, Rio) "As relações humanas e a nossa escola" RBEP, no 87, jul./set. 1962, p. $246-248$.
} 
necessário o autogoverno na escola, para que comecem a pensar a trabalhar em comunidade" (p. 248).

Com relação às professoras, a evidência da "conversão" deveria vir antes do divertimento. Lelièvre (2006) afirma que na França, no início do século XX, para poupar o corpo docente do "contato impuro do mundo", a legislação obrigava as congregações docentes a quatro tradições monásticas: moradia junto ao colégio, mesa comum, avental e, sobretudo, o celibato. Na metade do século XIX, os solteiros representavam mais de dois terços dos professores do ensino secundário, e a administração celebrava os "beneditinos laicos". Aliada às tradições monásticas, a escola republicana e laica reverenciava a cultivava o "espírito de sacrifício", a começar pelo "sacrifício sexual". No final do século XIX, Jules Ferry declarava com freqüência: "l'institutrice qui reste fille trouve dans l'éducation des enfants d'autrui la satisfaction du sentiment maternel, de ce grand instinct de sacrifice que toute femme a en elle." (FERRY, J., 1896, p. 259 apud LELIÈVRE, C., 2006, p. 72 - 73) O antigo ministro da instrução pública no período republicano afirmava que as professoras primárias solteiras realizar-se-iam na maternidade com os filhos de outras pessoas, os seus alunos. Elas dispensariam às crianças o seu sentimento maternal. Em 1966, no Brasil, o discurso de Heloísa Marinho ${ }^{33}$ às normalistas sobre a "missão" das educadoras nos jardins de infância não era muito diferente daquele proclamado por Ferry: "Além da formação intelectual, queremos para a educadora da infância formação de vida. Somente a vida pode dar o carinho maternal à relação do vivo interesse entre a educadora $\mathrm{e}$ a criança. (...) Muito podem nos ensinar conhecimentos iluminados pelo amor” (p. 66 grifos meus). Até os anos de 1950, as professoras solteiras continuavam representando maioria no ensino francês. As justificativas evocadas para o celibato são bastante significativas: "il est question de 'vocation', d'enseignantes qui se consacrent à leur tache, qui se 'sacrifient' en renonçant à une vie de femme pour atteindre par procuration les joies de la maternité scolaire ('pure' et sublimée)." (LELIÈVRE, C., 2006, p. 73) O "santuário escolar" passaria então de suas formas mais exacerbadas por estas "consagrações" que poderiam ser o preço a pagar pela "sacralização" da instituição escolar e de seus agentes, para que o poder "sagrado" fosse assegurado sem contestação possível. A figura da

\footnotetext{
${ }^{33}$ MARINHO, Heloísa. "Missão da educadora no jardim de infância”, RBEP, nº 101, jan./mar. 1966, p. 63 72.
} 
professora primária enquanto um exemplo, afastamento máximo daquilo que seria mundano estaria no centro da possibilidade da "santuarização" do trabalho docente. A forma escolar e educativa das escolas normais, que repousava inicialmente sobre o internato e as suas barreiras, é aqui essencial. As normalistas sofreriam uma formação que teria mais de "iniciação" e de "incorporação" a um corpo docente modelo do que de uma profissionalização. Nesta perspectiva, as escolas normais não deveriam formar as pessoas, mas deveriam transformar aquelas que adentravam o seu espaço em um tipo de pessoa. Como uma espécie de convento laico, as escolas normais originalmente seguiam a tradição eclesiástica, pretendendo que a educação das crianças fosse confiada a mulheres que viviam à parte do século e ignoravam os problemas cotidianos. Segundo Félix Pécaut (1879), considerado um dos principais idealizadores da educação republicana, as escolas normais propagavam "hábitos de espírito", maneiras de pensar, de julgar e de sentir que representavam o papel que as professoras primárias iriam desempenhar na formação do caráter e do espírito dos cidadãos. As professoras primárias deveriam ter uma vida privada exemplar e regrada, até mesmo uma vida sexual sacrificada em função do celibato (LELIÈVRE, C., 2006).

Mas a defesa do autogoverno também tinha razões práticas: o governo de si próprio era elemento fundamental para o governo de todos e para a existência da Pátria. De acordo com Francisco Pássaro ${ }^{34}$, em artigo publicado na RP em 1962. A criança é o destino da pátria, por isso deve-se proporcionar a elas muito afeto: "a sorte risonha de nossa terra repousa na formação moral, intelectual e física das crianças de hoje, homens de amanhã. À escola cabe o papel preponderante de dirigir essa formação, orientando, estimulando, combatendo, a fim de que a criança se integre numa comunidade sã, para o bem e progresso geral. (...) A imitação ocorre de maneira decisiva para sua progressiva integração social. É preciso dar à criança uma certa liberdade dirigida. O trabalho forçado degenera, corrompe o físico e amortece o espírito. (...) A infância é o elemento primordial de ligação entre o lar e a escola, estrutura inconteste da sociedade. $\mathrm{O}$ trabalho deve ser educativo, o trabalho manual acompanhado do intelectual, entrosados, constituem a pedra fundamental da formação do caráter e da personalidade. (...) Só assim haverá a integração social, a compreensão, o estímulo, a coragem para a melhoria do todo, com elevada educação

\footnotetext{
${ }^{34}$ PÁSSARO, Francisco. “O trabalho da criança”, RP, Jun./Jul., 1962, p. 18.
} 
espiritual, elementos indiscutíveis para o progresso e consolidação de nossa querida Pátria." (p. 18 - grifos meus)

1.1 O CONTROLE DA VIDA ÍNTIMA E DA ALMA: ENSINAR A “AMAR O QUE TEMOS QUE AMAR E A ODIAR O QUE TEMOS QUE ODIAR"

Ao entrar na escola normal, as estudantes passariam por uma verdadeira "conversão", um novo nascimento, uma recriação de si possibilitada, em alguns casos, também pelo internato e pela reclusão. O processo de formação das normalistas não dizia respeito apenas a se formar, mas sim a se reformar, e se refazer e não somente a se aperfeiçoar. O tipo de pessoa que deveria ser formado nas escolas normais tinha por objetivo a formação de um tipo de aluno. Durante este processo de conversão, parecia desejável que as normalistas esquecessem de si próprias para tornarem-se professoras primárias, partilhando todas de um mesmo habitus. Como se essa fosse uma das exigências da carreira: esquecer de si para poder cuidar dos outros. Ao elogiar o trabalho da educadora americana Eva Louise Hyde na organização do Colégio Bennett ${ }^{35}$, Heloísa Marinho fez a seguinte afirmação: "Miss Hyde legou ao Colégio Bennett, à educação brasileira, a obra de sua vida, dedicada aos ideais do cristianismo e da renovação educativa. O lema do Colégio Bennett, antes ser que parecer, sintetiza a personalidade de Miss Hyde. Esquecida de si mesma, sua vida e sua obra constituem unidade indivisível. Nunca apreciou homenagens, e estou certa que não aprovaria a que hoje lhe presto." (p. 72 - grifos meus) Marinho diz que todas querem continuar o trabalho de Hyde no Brasil. Para Marinho, todas alunas de Miss Hyde desejariam seguir o exemplo da professora.

Tanto nas escolas normais quanto nas escolas primárias, os ideais moralizadores seriam ensinados com maior eficiência à medida que pudessem ser transmitidos como que por contágio. Em artigo publicado na RBEP, em 1955, Sólon Borges dos Reis ${ }^{36}$ dizia que

\footnotetext{
${ }^{35}$ Instituição de formação de professores, de orientação religiosa, criada em 1888, no Rio de Janeiro.

${ }^{36}$ REIS, Sólon Borges dos. (Inicialmente publicado no Correio Paulistano, São Paulo). "Educação moral e cívica na escola secundária", RBEP, nº 57, jan./mar. 1955, p. 176 - 178.
} 
“o caminho do intelecto é de todos o mais precário para a transfusão das convicções morais e cívicas e respectivas diretrizes de vida íntima e social. Mas, elas conseguem passar com a maior segurança, fácil, rápida, solidamente, de coração a coração, propagando-se de espírito para espírito, se se transmitirem pelo processo de osmose das atitudes” (p. 176) Contudo, apesar da ênfase dada à importância da moralização na escola, seja através dos discursos, seja através dos exemplos, principalmente do exemplo oriundo da figura e da postura das professoras primárias, sempre era possível que a "osmose" não ocorresse e as crianças apresentassem posturas inadequadas ao desejável ou, segundo o vocabulário da época, "condutas anormais"37. Aqueles que fugiam ao tipo desejável do aluno, que não se adequavam às normas estabelecidas, que não eram contagiados pelo exemplo, representavam um problema e tornavam-se, segundo Orlando Parahim ${ }^{38}$, o "desespero" da família e dos professores. E a justificativa para os desajustados poderia ser encontrada na constituição física das crianças: “(...) pode uma doença diencefálica esconder-se por detrás dos atos imorais ou delitos reiterados. (...) Os centros corticais do lobo frontal do cérebro, as esferas superiores da consciência moral, passíveis de aperfeiçoamento pela educação controlam, moderam, inibem, freiam os impulsos instintivo-emotivos do diencéfalo, no estado de normalidade orgânica.” (p. 148 - 149) Parahim defendia que a educação seria capaz realizar uma verdadeira "profilaxia" ao preparar os alunos que vinha de lares “desorganizados” para a integração social. A integração social poderia ser promovida mediante a transmissão dos valores tradicionalmente originários do cristianismo e partidários de princípios enunciados nos pecados capitais, que eram muito difundidos nas escolas brasileiras, como o amor e o respeito ao próximo, o respeito e a valorização da família, etc. Moralizar significava também ensinar a pensar, a julgar e a sentir, discernindo o bem do mal e racionalizando os sentimentos. Em artigo escrito na RBEP em 1955, Abgar Renault $^{39}$ chamava a atenção para uma crise de valores pela qual o mundo atravessava no momento. Para contorná-la, o desafio lançado à educação seria o de realizar "o desenvolvimento, no indivíduo e no Estado, dos princípios mentais e éticos que tornarão

37 PARAHIM, Orlando. "Um inquérito escolar" (publicado inicialmente no Diário de Pernambuco, Recife), RBEP, no 97 jan./mar. 1965 p. 148 - 149.

${ }^{38}$ PARAHIM, Orlando. "Um inquérito escolar" (publicado inicialmente no Diário de Pernambuco, Recife), RBEP, nº 97 jan./mar. 1965 p. 148 - 149.

${ }^{39}$ RENAULT, Abgar. (publicado inicialmente no "Mensageiro Rural”, Minas Gerais) “A professora rural e o cumprimento de sua missão", o texto é um discurso que foi proferido pelo paraninfo da $2^{a}$ turma da Escola Normal Rural “A. S. Azevedo”, de Minas Gerais, RBEP, n 60, out./dez. 1955, p. 235 - 243. 
automáticas ou mais fáceis as escolhas que tivermos de fazer nas situações com que defrontamos". (p. 235-236) Renault cita Platão ao dizer que à educação cabe ensinar "a amar o que temos que amar e a odiar o que temos que odiar". Tornar automática uma escolha pode significar que os tais princípios estejam a tal ponto incorporados nos indivíduos que façam com que as suas escolhas sejam realizadas não simplesmente por impulso, mas tampouco com muita reflexão. Renault apresentou de forma sintetizada, um dos pilares que sustentaram a importância da moralização no período: o desenvolvimento de princípios mentais que tornassem quase automáticas as escolhas que deveriam ser feitas pelos indivíduos. Tais princípios seriam alcançados mediante certas práticas que estavam presentes nas escolas, como será visto adiante. Os autores dos artigos dos periódicos examinados, ao falarem sobre uma crise de valores que havia na época, enxergavam no desenvolvimento dos meios de comunicação uma crescente ameaça à ordem moral e ao ajustamento social. Em artigo publicado na RBEP em 1961, Lourenço Filho ${ }^{40}$, diretor do INEP, dizia que a "agitação pública", a propaganda, os atos legislativos e administrativos só poderiam realizar mudanças na medida em que modificassem as atitudes mentais e morais dos indivíduos, mas teriam a sua ação perturbada porque visariam a indivíduos cujos costumes já teriam sido formados. Desta forma, à educação sim caberia um "campo mais fecundo", por lidar com crianças e jovens, pessoas em formação. A preocupação com mídia talvez fosse devida ao estrago que ela poderia causar a todo o trabalho realizado pelas escolas, por pregar a liberdade de expressão. A crise de valores pode ser entendida também como uma crise da moralidade, o que significa que, quando algo entra em crise é porque passa por um período de contestação. Com a difusão dos meios de comunicação, a contestação tenderia a aumentar. Neste caso, para contorná-la, as crianças tornar-se-iam o principal objeto de atenção. As escolas apresentariam à criança uma forma de estar no mundo que ela aprenderia a desejar, negando o seu tempo presente e aderindo antecipadamente à representação do adulto que ela deveria vir a ser. Muitas das obrigações às quais os alunos eram submetidos na escola primária não tinham um fim em si mesmas, pois eram apenas exercícios destinados a preparar as crianças para a vida que elas tivessem quando se tornassem adultas. Enquanto um lugar de prevenção de comportamentos desviantes da norma estabelecida socialmente, a escola deveria evitar que crianças fossem

40 LOURENÇO FILHO “A propósito do centenário de John Dewey”, RBEP, nº 82, abr./jun. 1961, p. 157 164. 
transformadas no futuro em esposas e maridos promíscuos, prostitutas, alcoólatras, ladrões e malfeitores, porque teriam adquirido uma espécie de freio interno que iria auxiliá-las a conter-se e uma espécie de leme que guiaria a sua existência, devendo esta ser muito regrada e contida (DURKHEIM, 2008). Somente quando saíssem da escola é que se desenvolveriam as conseqüências da conduta aprendida e desenvolvida enquanto eram crianças.

\subsection{DO AUTOCONTROLE OU DA MORALIZAÇ̃̃O DAS PAIXÕES}

Durkheim pretendia moralizar as paixões humanas porque, segundo ele, as paixões controladas tornariam a vida mais tolerável. Em relação às paixões, não se tratava de cultivá-las, mas sim de reprimi-las: "na avaliação durkheimiana, as paixões humanas são apetites desmedidos e imoderados, desejos insaciáveis e sem limites, suportados que estão no que há de bicho no homem" (FERNANDES, 1994, p. 76). Desta forma, a criança era vista como o ser humano em estado bruto, um bárbaro, que ainda não tinha sido lapidado pelo processo de moralização intrínseco à educação. Durante o processo de escolarização, a criança percorreria então um caminho que faria dela um adulto normal. A vida escolar faria com que ela adquirisse o "espírito da disciplina", elemento importante da moralidade. O motor moral por excelência seria o espírito de sacrifício e de devotamento. Para tanto, seria preciso incentivar os indivíduos a perseguir os fins morais aos quais pudessem aderir, do contrário a nação poderia correr o risco de cair num estado de fraqueza moral, que ameaçaria a sua própria existência material. É importante observar que a necessidade do autocontrole se fazia presente tanto na formação das professoras primárias quanto na formação das crianças. O relatório da "Conferência das Escolas para a Compreensão Internacional"41, promovido pela UNESCO, publicado na RBEP em 1956, alertava para as consequiências que o trabalho com as crianças e com os jovens poderia trazer para os

\footnotetext{
41 "A formação de professores" Trata-se do relatório apresentado na Conferência das Escolas para a Compreensão Internacional, em colaboração com a UNESCO, em 1955. RBEP, nº 64, out./dez. 1956, p. 141 -179 .
} 
professores. O exercício do magistério é considerado fatigante, exige autocontrole, objetividade e, mais do que qualquer outra ocupação, "deve-se recordar que aqueles que desempenham com sucesso sua tarefa de professor, por muitos anos, demonstram, com isso, possuírem uma rara habilidade para resistir ao esforço e uma sólida saúde mental". (p. 160) No tocante ao autocontrole que deve ser adquirido pelos alunos durante o processo de escolarização, é fértil observar o artigo escrito por Robert J. Havighurst ${ }^{42}$, pesquisador do INEP, acerca das tarefas evolutivas das crianças e dos adolescentes, publicado na RBEP em 1957. O autor afirmou que, ao terminar a escola primária, os alunos teriam um repertório de atitudes sociais que eles "colheram" dos professores, dos colegas, da família, da comunidade e através do rádio, da TV, dos livros e das aulas. Há poucas possibilidades de que esse repertório, uma vez constituído, venha a mudar. Seria justamente na idade escolar que deveriam ser desenvolvidas nas pessoas a consciência moral e uma escala de valores que permitissem a elas alcançar um "controle emocional interior". E o autor dá o seguinte exemplo: "a decisão de trabalhar e ganhar dinheiro em vez de ir ao cinema e gastar, deve ser julgada, a seus olhos e aos olhos dos demais, como realmente digna do sacrifício de se privar da satisfação imediata que lhe proporcionaria o cinema.” (p. 135)

Segundo Durkheim, é por meio da disciplina que se aprende a moderação do desejo, sem a qual o homem não poderia ser feliz. Graças à autoridade de que são revestidas, as regras morais tem força para barrar os desejos, as necessidades e os apetites quando eles se tornarem imoderados. A moral tem a função de limitar e conter. Mediante a disciplina seria possível ensinar a criança a moderar os seus desejos, limitar os seus apetites e definir os objetivos de sua atividade; essa limitação seria condição para a sua felicidade e para a sua "saúde" moral. Quando as tendências pessoais são libertadas de todo comedimento, quando nada as limita, elas se tornam tirânicas e seu primeiro escravo é o próprio indivíduo que as experimenta. Desta maneira, um dos principais poderes que deve ser desenvolvido pela educação é a atitude de maestria para consigo mesmo. É preciso conter a si próprio e aprender a resistir a si próprio. A disciplina moral tem papel fundamental na formação do caráter e da personalidade. O que é mais essencial no caráter é a capacidade de autocontrole, é essa faculdade de conter, de inibir os impulsos. O autocontrole seria então como uma maestria de si que é forjada pela disciplina moral. A propósito disso, Heloísa

\footnotetext{
${ }^{42}$ HAVIGHURST, Robert J. "Tarefas evolutivas das crianças e dos adolescentes" RBEP, nº 67, jul./set. 1957 , p. $130-143$.
} 
Fernandes (1994) apresenta a seguinte reflexão: "Mas, quanto à subjetividade, não seria a disciplina uma violentação, uma diminuição do ser, uma mera polícia exterior e material cuja única utilidade seria a de impedir que certos atos sejam cometidos? Limitando e refreando os desejos, impedindo que se desenvolvam sem limites, não violentaria a constituição natural do homem, entravando seu livre desenvolvimento?” (p. 84).

Se a infância seria a fase da vida propícia ao enquadramento dos atos e ao desenvolvimento do autocontrole, a adolescência mereceria atenção redobrada, pois seria o momento no qual as pessoas tenderiam a contestar as normas estabelecidas. Sólon Borges dos Reis ${ }^{43}$, diretor do CPP, ao escrever sobre educação moral e cívica na escola secundária, em artigo publicado na RBEP em 1955, afirmou que era responsabilidade dos professores melhorar o "nível" moral e cívico da juventude: "partindo do senso da própria responsabilidade e do estudo da alma da juventude, a fim de conhecê-la, compreendendo-a bem. Então, poderão constatar que os professores trabalham como numa verdadeira vitrina. O menor de seus gestos, a mais rápida das atitudes, impressiona os espectadores. Seu público são os seus alunos. Público condescendente na aparência, mas exigente, rigorosamente exigente no seu íntimo. E é no íntimo de si mesmo que o aluno da escola secundária vive de preferência sua vida de adolescente. (...) só os exemplos conseguem contagiar a alma e alcançar aquilo que é, realmente, o objetivo da educação moral e cívica: - a modificação da conduta da juventude, em termos de maior consonância com os padrões éticos e os ideais e normas que podem servir constantemente à pátria”. (p. 178) Segundo relatório apresentado na "Conferência das Escolas para a Compreensão Internacional"44, em colaboração com a UNESCO, em 1955, e publicado na RBEP em 1956, a adolescência seria a última fase da vida conhecida como "plástica", e para a maioria a última que alcançaria o sistema escolar comum, desta forma, seria provável que ela fosse a única que influenciasse as atitudes em relação às situações diárias na vida. O relatório sugeria que os professores deveriam proporcionar o desenvolvimento do raciocínio, da criatividade e da honestidade dos alunos, e "sobretudo devem eles estar continuamente em guarda contra o

\footnotetext{
${ }^{43}$ REIS, Sólon Borges dos. (Inicialmente publicado no Correio Paulistano, São Paulo). "Educação moral e cívica na escola secundária”, RBEP, n 57, jan./mar. 1955, p. 176 - 178.

44 "A formação de professores" Trata-se do relatório apresentado na Conferência das Escolas para a Compreensão Internacional, em colaboração com a UNESCO, em 1955. RBEP, nº 64, out./dez. 1956, p. 141 -179 .
} 
perigo resultante do desprezo, da humilhação, do sarcasmo e de atitudes semelhantes que desencorajam o modo de pensar criador e original e outras atividades eficazes. Eles não devem simplesmente notar os erros, mas preocupar-se sobretudo em ressaltar o que há de bom no trabalho dos alunos, e mostrar sempre, com seu próprio exemplo, qual comportamento que gostaria de encontrar neles." (p. 146) Este mesmo artigo chama a atenção para o fato de que os professores, quando estão em formação, são geralmente adolescentes e, nesta fase, a sua personalidade ainda pode ser transformada. De acordo com o relatório, o caráter e a idoneidade podem transparecer através dos interesses que os professorandos demonstram durante a sua escolaridade: "o ideal seria que se aceitassem na profissão somente aqueles que tivessem vida retrospectiva mentalmente sã e possuíssem o poder necessário de entusiasmar os jovens com um senso perspicaz e direção e objetividade." (p. 168) O poder de entusiasmar os jovens, referido no relatório, pode transparecer através de uma maneira de ser, de falar, de um determinado estilo que os professores desenvolvem e que causam atração nos alunos. $\mathrm{O}$ ato de ensinar, além da sabedoria acerca do conteúdo ministrado, contaria também com uma certa sedução por parte dos professores, que teria relação com a sua personalidade.

\subsection{A FORMAÇÃO DA PERSONALIDADE}

Etimologicamente, a palavra "personalidade", de origem grega, significa máscara em grego, "persona". A palavra dá a idéia de algo que soa através, como a máscara ou um faz de conta, a representação de algo que na verdade não existe concretamente, que é uma fantasia. De acordo com a sua origem, a palavra personalidade está relacionada com a aparência externa da pessoa. Quando se fala em personalidade, normalmente remete-se a um conjunto de características próprias de um indivíduo. Sendo essas particulares, elas distinguem as pessoas entre si. Resultado de experiências e de influências que as pessoas receberam durante toda a vida, a personalidade seria a reunião de um conjunto de modos de agir, especialmente para com as outras pessoas, mas também de preferências e de gostos, que a tornariam visível através da maneira de usar o corpo e de adorná-lo. A língua, por exemplo, é uma forma de expressão da personalidade. O professor José Américo da 
Costa $^{45}$, em artigo publicado na RP em 1959, chamava a atenção para a necessidade de se cultivar nos alunos o gosto pela legitimidade da língua pátria e para a importância desta na apresentação pessoal dos indivíduos. Segundo o autor, os alunos deveriam "querer cultivar, com esmero, aspecto tão importante da sua personalidade." (p. 28) As formas de ser e de estar no mundo, de aparecer nele e de se apresentar diante do outro estão relacionadas com a personalidade do indivíduo e foram objeto de atenção nos discursos veiculados nas fontes examinadas. Cabe então perguntar o quanto as práticas de moralização exercidas pela escola influenciavam na constituição da personalidade dos alunos, sejam eles os alunos da escola normal, futuros professores, sejam eles as crianças e os adolescentes. Segundo Alberto Ferreira Giúdice ${ }^{46}$, diretor de grupo escolar, em artigo publicado na RP em 1959, seria preciso ter muito zêlo para com a educação primária, pois a personalidade dos indivíduos seria decorrente dela. Para Sá Teles ${ }^{47}$, inspetor escolar, o "bom desempenho" do ensino dependeria da personalidade dos professores: “A personalidade docente, que será o fator eletrizante da ação metódica do professor, se expressa por um conjunto de características próprias tais como a aparência, vocação, ajustabilidade no plano espiritual, moral, social, e vida interior capaz de motivar os alunos para o tipo de trabalho ou atividade que se deseje realizar." (p. 28)

Em 1951, o "Seminário Interamericano de Educação Primária"48, promovido pela UNESCO e pela OEA, dizia que o controle do Estado acerca da educação deveria basearse em razões de ordem pública, de higiene e de moral, impostas pela Constituição e pelas leis. A educação primária teria o caráter de órgão fundamental para a formação do cidadão, impondo valores e desenvolvendo o espírito de cooperação, de lealdade, de tolerância e de responsabilidade. Com relação à formação de professores, o seminário sugeria que fosse realizado um "exame de personalidade" no momento da seleção e da admissão à escola normal e esta teria uma "base moral" que consistiria na organização do seu regime interno. No ano seguinte, a "X Conferência Nacional de Educação"49 dizia que a educação teria por

\footnotetext{
${ }^{45}$ COSTA, José Américo da. "Análise sintática", RP, jan./1959 p. 27 - 28.

${ }^{46}$ GIÚDICE, Alberto Ferreira, "Educação”, RP, set./1959 p. 20.

${ }^{47}$ TELES, Sá. "Problemas do método", RP, mai./1960, p. 28.

48 “Seminário Interamericano de Educação Primária”, promovido pela UNESCO e pela OEA. RBEP, no 42 , abr./jun. 1951, p. $109-155$.

49 “X Conferência Nacional de Educação”, RBEP, n 48, out./dez. 1952, p. 177 - 189.
} 
objetivo o desenvolvimento harmonioso da personalidade, do ponto de vista físico, moral e intelectual, devendo favorecer o ajustamento familiar e social do indivíduo e tornando-o capaz de contribuir para a melhoria da comunidade, habilitando-o no desempenho consciente dos deveres cívicos e preparando-o "espiritualmente para se opor aos antagonismos entre classes, raças e perseguições" por motivos religiosos ou políticos.

Riva Bauzer ${ }^{50}$, professora de psicologia, em 1954, publicou na RBEP um artigo intitulado "Conceituação de Personalidade", no qual definiu o termo como um conjunto das características e dos atributos de uma pessoa, que trazem uma marca que distingue o indivíduo de seus semelhantes (estilo, modo de ser, etc.). Para ela, "ser, valer, parecer", correspondem às personalidades: real, moral e social. O indivíduo "normal" seria aquele capaz de ajustar-se com facilidade ao ambiente que o cerca, recebendo novos padrões sociais com convicção, mas "sem fanatismos", seria um misto de conservador e tolerante: "nossos comportamentos são muito mais limitados pelo grupo cultural a que pertencemos, do que nos apraz pensar. De maneira geral, o código moral, em cada época, limita-se a justificar as formas de comportamento que se tornaram necessárias para acompanhar as transformações técnicas e sociais do grupo". (p. 186) Bauzer terminava o texto dizendo que uma personalidade harmoniosa, bem estruturada, seria aquela que desenvolveria "dons", aptidões e inclinações, de acordo com as mais desejáveis formas de vida preconizadas pela cultura.

Em 1955, foi publicado na RBEP um artigo de Noemi Silveira Rudolfer ${ }^{51}$, diretora do Laboratório de Psicologia Educacional de São Paulo, intitulado "Psicologia da personalidade". Segundo a psicologia funcionalista, a personalidade seria definida como um conjunto integrado dos atributos físicos, psíquicos e sociais que caracterizariam num "núcleo indivisível e sempre identificável” o que chamamos "eu”. A autora cita Freud, por afirmar que a personalidade tem uma estrutura básica inconsciente constituída dos impulsos instintivos - o Id. Em contato com a realidade, o Id adquiriria uma estrutura consciente fora da interiorização da realidade, o Ego, e que reprimiria em parte o Id: "Perante as exigências morais, o Ego se transforma em parte numa estrutura que vai

\footnotetext{
${ }^{50}$ BAUZER, Riva. (Boletim da CBAI, Rio) “Conceituação de Personalidade”, RBEP, nº 55, jul./set. 1954, p. $180-185$

51 RUDOLFER, Noemi Silveira. "Psicologia da personalidade" (publicado inicialmente em Letras da Província, Limeira), RBEP, nº 57, jan./mar. 1955, p. 157 - 165.
} 
constituir a consciência moral, o Super-ego. (p. 158 - grifos meus) Entre os exemplos que Rudolfer cita no artigo, é curioso aquele que diz respeito à mulher esquimó: "é submissa, obediente, dócil, tal como é o padrão desejável entre nós”. Ela conclui o artigo sugerindo que um serviço de higiene mental poderia diagnosticar o tipo de personalidade para tratamento e educação adequados e fazer uma profilaxia individual e do grupo das moléstias mentais. No ano seguinte, o termo "higiene mental" associado à personalidade também está presente no relatório da "Conferência das Escolas para a Compreensão Internacional" ${ }^{, 52}$, promovida pela UNESCO, publicado na RBEP. De acordo com o artigo, "uma situação de boa saúde mental torna o indivíduo capaz de desenvolver sua personalidade, conseguindo uma adaptação adequada, seja às forças externas, seja à sua própria natureza. Já que nem as forças externas nem a natureza interior do homem permanecem sempre invariáveis, deve a higiene mental implicar uma contínua adaptação". (p. 155) No mesmo ano, Paulo de Almeida Campos ${ }^{53}$, pesquisador do INEP, ao escrever na RBEP sobre os planos e os programas das escolas primárias, alertava para o fato de que, no início do século XX, pretendia-se dotar os alunos de uma erudição enciclopédica, esquecendo-se da formação integral da personalidade dos mesmos. No entanto, naquele momento, os programas deveriam favorecer a formação integral da personalidade dos educandos e fomentar o conhecimento do meio social em que viviam, para contribuir com o progresso da comunidade. Alberto Rovai ${ }^{54}$, diretor de escola normal, em artigo publicado na RBEP em 1958, fazia uma crítica à escola secundária por ser ela, e não o aluno, o centro da educação. Segundo Rovai, o ensino secundário deveria incutir nos alunos o gosto pela cultura, pelo "trabalho bem feito" e proporpocionar o desenvolvimento harmônico da personalidade, nos seus aspectos "intelectual, moral e físico". O ensino ministrado no ginásio deveria continuar a ser formativo e humanístico, "continuando o processo de enriquecimento científico, artístico, moral e cívico". O professor Jair Augusto de Oliveira $^{55}$, em artigo publicado na RP em 1960, também definia a personalidade pelo

\footnotetext{
52 "A formação de professores" Trata-se do relatório apresentado na Conferência das Escolas para a Compreensão Internacional, em colaboração com a UNESCO, em 1955. RBEP, nº 64, out./dez. 1956, p. 141 -179 .

${ }^{53}$ CAMPOS, Paulo de Almeida. "Seminário regional sobre planos e programas da escola primária", RBEP, n 64 , out./dez. 1956, p. $73-93$.

${ }^{54}$ ROVAI, Alberto. (Folha da Noite, São Paulo) "Em nossa escola secundária, a escola, e não o aluno, é o centro da educação", RBEP, n 70, abr./jun. 1958, p. 132 - 136.

${ }^{55}$ OLIVEIRA, Jair Augusto de. "O programa do $4^{\circ}$ ano primário fundamental e a divisão pelos meses letivo do ano - outras considerações oportunas", RP, abr./1960, p. 36 - 40.
} 
trinômio "física, intelectual e moral". Referindo-se à escola primária, ele dizia que, naquele momento, a escola não era mais considerada como "uma simples máquina de alfabetização". Suas responsabilidades seriam outras: "sendo um instrumento de formação física, intelectual e moral, tem ainda, a missão de promover a integração harmoniosa da criança no seio da comunidade, fornencendo-lhe elementos próprios e indispensáveis para que se torne um fator de progresso individual e social." (p. 39) As escolas deveriam promover a formação integral da personalidade dos alunos, indicando quais atitudes mentais e morais deveriam ser desenvolvidas por eles, e essa tarefa cabia aos professores cumprir.

O professor Nunes Mendonça ${ }^{56}$, em artigo publicado na RBEP em 1956, evocava Dewey para falar da formação da personalidade. Esta seria valorizada segundo uma aproximação do individualismo e do coletivismo, em uma "síntese democrática". A personalidade, cuja formação estaria condicionada ao meio, considerada fonte de originalidade e fundamento de liderança, seria então a combinação do "individual" com o "social”. A propósito disso, Mendonça faz a seguinte afirmação: "o indivíduo isolado proclama Dewey - nada é; só mediante a assimilação das instituições organizadas atinge ele a verdadeira personalidade". (p. 150) O autor também citava Gilberto Freyre, através da seguinte afirmação: "para se realizar como natureza humana, o animal humano tem de socializar-se, personalizar-se, e tornar-se herdeiro portador e criador de cultura, ou pelo menos participante da obra de criação, ou de conservação de cultura". (p. 150) O controle acerca da conduta e da formação da personalidade dos alunos também é evidenciado pelo viés democrático, como na seguinte citação: “orientada no sentido progressista, a escola é capaz de proporcionar 'hábitos de espírito que permitam mudanças sociais sem o ocasionamento de desordem', na feliz expressão de Dewey." (p. 151) O termo empregado por Mendonça, "hábitos de espírito", também pode ser entendido como personalidade. Nesta perspectiva, a escola era vista como um instrumento de evolução, de renovação e de progresso. Conciliando todos os homens, a escola deveria acentuar tudo aquilo que vinculasse os povos para resultados que trouxessem benefícios a todos, independente de credo, nacionalidade ou raça. Assim, homens independentes - que tivessem desenvolvido

\footnotetext{
${ }^{56}$ MENDONÇA, Nunes. (Correio de Aracaju, Aracaju) "Educação e progresso social", RBEP, $\mathrm{n}^{\circ}$ 62, abr./jun. 1956, p. $149-153$.
} 
hábitos de higiene, trabalho e cooperação - serviriam ao próximo e contribuiriam na "luta contra a pobreza para um mundo melhor”. Posição semelhante tem Newton Sucupira ${ }^{57}$, membro do Conselho Federal de Educação, que foi evidenciada em artigo publicado na mesma revista em 1963. Para ele, a "formação espiritual", associada à constituição da personalidade, não deveria ser desenraizada de suas condições socioculturais. A formação integral visaria ao desenvolvimento harmonioso da personalidade em seus "aspectos essenciais": intelectual, moral, social, vocacional e físico, objetivando preparar homens livres e responsáveis, integrados com o mundo.

\subsection{ENTRE CONDUZIR E CONFORMAR: DO ESTÍMULO À “CAPACIDADE CRIADORA DO INDIVÍDUO" À PADRONIZAÇÃO DAS CONDUTAS}

O Centro Brasileiro de Pesquisas Educacionais (CBPE) foi criado em 1956, sob a liderança de AnísioTeixeira, então diretor do Instituto Nacional de Estudos Pedagógicos (INEP). Durante os anos 50 e 60, o CBPE, contando com um grupo de pesquisadores e professores, desenvolveu um projeto que tinha como objetivo o desenvolvimento de pesquisas que pudessem subsidiar políticas públicas que seriam implantadas na área educacional. A mesma estrutura desta instituição foi reproduzida nos Centros Regionais de Pesquisas Educacionais (CRPE), onde foram realizados estudos acerca das condições culturais, políticas, econômicas e sociais de cada região brasileira, além de projetos sobre o processo de ensino e de aprendizagem. O CRPE de São Paulo criado a partir de um convênio entre o Ministério da Educação e a Reitoria da Universidade de São Paulo (USP). Segundo Rosario Genta Lugli (2002), a criação destes centros expressava a crença nos vínculos existentes entre educação e ciências sociais e representava a transição de uma política empírica em educação para uma política científica e racional. Este processo repercutiu diretamente no trabalho dos professores, de modo que a sua experiência também passou a ser desvalorizada em detrimento do conhecimento técnico.

\footnotetext{
${ }^{57}$ SUCUPIRA, Newton. "Princípios da educação de grau médio na lei de diretrizes e bases", RBEP, n 91 , jul./set. 1963, p. $45-67$.
} 
Associada às práticas de moralização, a questão da criatividade também esteve presente nas fontes investigadas. Paulo de Almeida Campos ${ }^{58}$, pesquisador do INEP, em artigo publicado na RBEP em 1956, derivado do seminário regional sobre planos e programas da escola primária, dizia que a educação neste nível de ensino deveria transmitir "uma concepção do mundo e da vida" na qual se integrassem a "teoria e a ação, o pensamento e a conduta" que exaltasse a "capacidade criadora do indivíduo". (p. 79) O relatório ${ }^{59}$ apresentado na Conferência das Escolas para a Compreensão Internacional, em colaboração com a UNESCO, publicado na RBEP em 1956, também sugeria que cabia aos professores proporcionar o desenvolvimento da criatividade nos alunos. E ressaltava o seguinte: "sobretudo devem eles estar continuamente em guarda contra o perigo resultante do desprezo, da humilhação, do sarcasmo e de atitudes semelhantes que desencorajam o modo de pensar criador e original e outras atividades eficazes. Eles não devem simplesmente notar os erros, mas preocupar-se sobretudo em ressaltar o que há de bom no trabalho dos alunos, e mostrar sempre, com seu próprio exemplo, qual comportamento que gostaria de encontrar neles.” (p. 146) Paulo Rosas ${ }^{60}$, diretor do Instituto de Psicologia do Trabalho de Pernambuco, em artigo publicado na RBEP em 1967, a propósito do exame psicológico realizado em candidatas ao magistério primário, sugeria que as professoras deveriam "evitar soluções fáceis, fugindo a perguntas incômodas, mentir, e demonstrar desinteresse pela verdade. Evitar impor à criança um modelo pré-fixado de reações padronizadas não criadoras." (p. 120) No entanto, afirmava que muitas professoras aceitavam "quase passivamente a supervisão de terceiros" e não lhes pareceria importante "ser criativo e original". (p. 130) Em artigo publicado na RBEP em 1964, o professor Raimundo Mata ${ }^{61}$ criticava a exigência de atendimento a padrões e a "standards" de rendimento, por serem desestimulantes e repressores da criatividade. Segundo o autor, "o pensamento convergente leva à conformidade. A capacidade criadora do indivíduo tem

\footnotetext{
${ }^{58}$ CAMPOS, Paulo de Almeida. "Seminário regional sobre planos e programas da escola primária" RBEP, no 64, out./dez. 1956, p. 73-93.

59 "A formação de professores" Trata-se do relatório apresentado na Conferência das Escolas para a Compreensão Internacional, em colaboração com a UNESCO, em 1955. RBEP, nº 64, out./dez. 1956, p. 141 -179 .

${ }^{60}$ ROSAS, Paulo. "Exame psicológico de candidatas ao magistério primário de Maceió", RBEP, ${ }^{\circ}{ }^{107}$, jul/set. 1967, p. $111-151$.

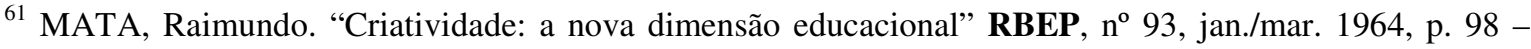
100.
} 
sido freqüentemente reprimida pela educação e ele já nem pode reconhecer seu potencial criativo." (p. 100) Publicado na mesma revista, no ano de 1976, o artigo de Eunice Alencar $^{62}$, professora universitária, afirmava que o pensamento criativo teria "mais chances de ocorrer nas famílias em a criança é encorajada a pensar, sua curiosidade é alimentada e sua imaginação é considerada algo importante a ser conservado.” (p. 376)

A valorização da individualidade como algo que deveria ser cultivado na prática educativa também apareceu nas fontes consultadas. No entanto, a questão surge como algo um tanto paradoxal à medida em que, no período de expansão da educação pública, o tipo de educação ministrado parecia obedecer a uma lógica de tinha por objetivo massificar e generalizar o ensino, para que este pudesse efetivamente ser oferecido a todos. Contudo, segundo José Mário Pires Azanha (1987), essa idéia de uma "escola aligeirada" como preço da democratização, "sempre causou repulsa aos defensores do ideal democrático". (op. cit., p. 32) Entre eles estava Anísio Teixeira. Em artigo ${ }^{63}$ publicado na RBEP em 1956, o autor, educador e diretor do INEP, afirmava que, se há tarefa em que não se poderia obedecer a planos pré-fixados, esta seria a educação. Para ele, "a educação é um cultivo individual, diferente em cada caso. Quem se educa é o aluno e a ele tem o mestre de atender. Se algum serviço jamais terá aspecto mecânico, este será o da educação. Ciência, técnica e filosofia da educação sempre hão de se constituir não receitas, mas esclarecimentos para conduzir a experiência única e exclusiva, que é a da educação de cada um” (p. 19 - 20) O autor tecia uma crítica à administração pública brasileira, por tentar "racionalizar" e uniformizar o trabalho pedagógico. Neste período, a uniformização do trabalho docente pode ter sido derivada principalmente de dois eventos: a centralização da administração pública promovida pelo governo durante o Estado Novo e a criação do CRPEs. O professor João José da Silveira Campos ${ }^{64}$, em artigo publicado na RP em 1959 sobre a filosofia da administração escolar, defendia que o fim principal da educação nos países democráticos seria promover o fortalecimento físico, intelectual e moral dos educandos. Para alcançar este objetivo, a administração escolar deveria ser considerada como a "sistematização da teoria da vida", por "vida" o autor entendia a própria escola. No

\footnotetext{
${ }^{62}$ ALENCAR, Eunice M. L. Soriano de. "Relação entre o nível de criatividade do professor e de seus alunos" RBEP, nº $^{\circ}$ 139, jul./set. 1976, p. $376-380$.

${ }^{63}$ TEIXEIRA, Anísio. “A administração pública brasileira e a educação" RBEP, nº 61, jan./mar. 1956, p. 3 23.

${ }^{64}$ CAMPOS, João José da Silveira. "Filosofia da administração escolar" RP, mar./1959, p. 6.
} 
entanto, advertia Campos "a administração não constitui ciência à parte quando considerada uma forma de procedimento, padronização de conduta, automatização de respostas" (p. 6).

Durante a ditadura do Estado Novo (1937-1945), o governo buscou centralizar e uniformizar a administração pública, influenciando na organização do sistema de ensino e chegando às escolas. A economia de substituição de importações, iniciada em 1930, acelerava-se e diversificava-se entre 1945 e o início da década de 1960. A Constituição de 1946 já havia fixado a necessidade de novas leis educacionais que substituíssem as anteriores, consideradas ultrapassadas para o novo momento econômico e político que o país passava a viver (SKIDMORE, 1982). Além disso, o final da segunda guerra mundial também apresentava ao país novas necessidades que a educação não podia ignorar: era um período de transição marcado por várias manifestações a respeito dos rumos do sistema educacional. Em artigo publicado na RBEP em 1956, Anísio Teixeira ${ }^{65}$ apontava para o fato de que, com o desenvolvimento da burocracia e da industrialização e com o crescimento das organizações humanas, o comportamento dos indivíduos acabava sendo afetado, apresentando um aspecto "uniformizante". O modelo de produção em massa, que revolucionou a indústria nos anos de 1920, alterava não apenas a organização do trabalho, mas estendeu-se por décadas a vários setores da sociedade, influenciando até mesmo a educação, impulsionando as tendências do Estado em aumentar seu poder sobre o indivíduo e o seu trabalho. Segundo Teixeira, "o espírito das leis do Estado Novo foi o da mais extrema centralização, uniformização e mecanização da administração pública". (...) Falando em um jargão pseudo-científico de 'racionalização dos serviços'. A fúria uniformizante, centralizante e mecânica do Estado veio envolta ao espectro do progresso. As 'leis orgânicas' foram feitas com a finalidade de uniformizar a educação” (p. 7). Durante o Estado Novo, o governo elaborou um estatuto único para o funcionário público com um sistema de direitos e deveres. Foi nesse momento também que foram criadas as secretarias de educação. O sistema escolar foi envolvido neste plano de unificação e passou a ser dirigido pelo governador, assistido pelo secretário e pelo departamento de administração do serviço público estadual (DPS). Segundo Teixeira, antes dessas mudanças administrativas, "as escolas eram dirigidas por departamentos de educação,

\footnotetext{
${ }^{65}$ TEIXEIRA, Anísio. “A administração pública brasileira e a educação” RBEP, nº 61, jan./mar. 1956, p. 3 23.
} 
promovidos por diretores gerais, que conheciam seu trabalho e tinham poder para administrar técnica e materialmente as escolas, cujo pessoal lhes era subordinado. Havia, pois, espírito profissional e unidade na direção das escolas, condições imprescindíveis para um mínimo de eficiência. O diretor respondia perante um secretário, geralmente do interior, ao qual cabia não a administração, mas a supervisão geral da educação. (...) $\mathrm{O}$ espírito de 'racionalização' criou as secretarias de educação. Dada a unificação do governo, o real diretor geral é o governador com o DPS estadual, e o secretário mero assistente em educação. Assim, as secretarias são muito menos autônomas que as antigas diretorias-gerais. A individualidade das escolas foi perdida, tornando as escolas instituições desenraizadas, imprecisas e fluidas" (p. 16). A mobilidade dos professores, diretores e funcionários teria gerado essa "perda de personalidade" da instituição e a educação teria sido transformada em uma atividade estritamente controlada por leis e regulamentos, e o ministério da educação e as secretarias de educação em órgãos de registro, fiscalização e controle formal do cumprimento de leis e regulamentos. Durante a ditadura do Estado Novo, o ministério da educação foi transformado no organismo central de controle e fiscalização da educação. Como conseqüência de tal situação, Teixeira afirmava que "com efeito, o fato de haverem pedido a autonomia quanto a pessoal e material inicia a desintegração da escola. Essa desintegração se completa com a supressão da autonomia quanto ao ensino, sua seriação, métodos e exames. Levada a ordenação externa da escola até esse ponto, é evidente que nada restará senão o automatismo de diretores e mestres, a executar o que não planejaram, nem pensaram, nem estudaram, como se estivessem no mais mecânico dos serviços"(p. 19- grifos meus). Para o autor, cabia ao governo prover os recursos para que a educação escolar fosse realizada e não prescrever as condições internas de seu processamento. As leis deveriam limitar-se a indicar os objetivos da educação e a fixar condições externas para que a mesma se efetivasse. Não poderia prescrever as condições internas do seu processamento, pois essas condições seriam "resultantes de uma ciência e de uma técnica em constante desenvolvimento, e objeto de controle da consciência profissional dos próprios educadores, e não de leis.” (p. 21)

O sociólogo e professor da Universidade de São Paulo Fernando de Azevedo ${ }^{66}$, em artigo publicado na RBEP em 1955, dizia o seguinte: "a liberdade surge como um

\footnotetext{
${ }^{66}$ AZEVEDO, Fernando de. "Educação e liberdade" (publicado inicialmente no jornal O Estado de S. Paulo) RBEP, $n^{\circ}$ 60, out./dez. 1955, p. 243 - 249.
} 
problema com a emergência da personalidade individual, que Durkheim desprende da evolução das sociedades e lhe parece o fato mais constante da evolução social. É com a divisão do trabalho e a diferenciação social que o indivíduo deixa de ser o "homem de um só grupo' e tende a libertar-se pela variedade de suas ligações.” (p. 245) Em 1979, o artigo de Lucy Serrano Vereza ${ }^{67}$, secretária de educação e cultura do município do Rio de Janeiro, publicado na RBEP, a propósito do ensino da linguagem, defendia a valorização das características individuais das crianças. Segundo Vereza, quando chegam à escola, as crianças já trazem uma soma de experiências vividas, um conjunto de vivências e uma "série de hábitos e de preconceitos" de toda natureza. "A escola já encontra o aluno dotado de atitudes e hábitos que se fixaram, marcado de comportamentos favoráveis ou desfavoráveis e, por vezes, também a linguagem foi atingida. À escola cabe começar um trabalho que se iniciou no lar; ela deve aprimorá-lo e ampliá-lo. A criança deve ser conduzida para a aprendizagem formal, sem que suas características básicas sejam violentadas" (p. 57). Alberto Rovai ${ }^{68}$, diretor de escola normal, em artigo publicado na RBEP em 1958, citou Jacques Maritain para afirmar que seria preciso levar em conta as diferenças individuais no processo educativo. $\mathrm{O}$ autor também criticava a reprovação em massa. Newton Sucupira ${ }^{69}$, membro do Conselho Federal de Educação, em artigo publicado na RBEP em 1963, defendia que cada aluno deveria ser valorizado na sua individualidade e jamais ser reduzido a um "denominador comum de aluno tipo". (p. 45) O professor Faria $\mathrm{Netto}^{70}$, em artigo publicado na RP em 1960, defendia que o ensino devia ser ministrado o ensino "sem uniformidade humana, pois há diversidades em relação às faculdades morais e intelectuais" (p. 28). A personalidade dos alunos deveria ser estudada de modo a auxiliar o trabalho dos professores, que eram concebidos mais como orientadores do que como detentores do saber: "sabe-se que a palavra educar vem do vocábulo latino educare e que procede de levar, conduzir, e significa cuidar, criar, fazer

\footnotetext{
67 VEREZA, Lucy Serrano. (Secretária de Educação e Cultura do município do Rio de Janeiro) “Aprendizagem inicial da linguagem no ensino de $1^{\circ}$ grau" RBEP, n 144, mai./ago. 1979, p. 53 - 57.

${ }^{68}$ ROVAI, Alberto. (Folha da Noite, São Paulo) "Em nossa escola secundária, a escola, e não o aluno, é o centro da educação” RBEP, nº 70, abr./jun. 1958, p. 132 - 136.

${ }^{69}$ SUCUPIRA, Newton. "Princípios da educação de grau médio na lei de diretrizes e bases" RBEP, no 91 , jul./set. 1963 , p. $45-67$.

${ }^{70}$ FARIA NETTO, F. de. “A educação bandeirística” RP, out./1960, p. 28 - 29.
} 
crescer" (p. 29) O autor também afirma que, nos primeiros anos de vida, as crianças vão adquirindo os hábitos de seus pais e das pessoas mais próximas a elas. Contudo, diz Faria Netto, "mais tarde, pode vir o desajustamento infantil ao normal" (p. 29). Ou seja, apesar da adesão das crianças ao comportamento daqueles que lhes são próximos, era previsto que elas poderiam vir a apresentar "desajustamentos", termo comum na época, em relação ao grupo considerado “normal”. Em artigo publicado na RBEP em 1971, João Eduardo Villalobos $^{71}$, professor da Universidade de São Paulo, tratou da individualidade de outra forma, versando sobre a possível marginalidade daqueles que não se encaixam nos padrões. Para o autor, "a moralidade poderá provocar uma situação de tragédia contínua, por faltar o apoio dos dogmas, dos mitos e das esperanças que a própria sociedade criou como instrumento de auto-preservação. (...) À comodidade das soluções coletivas e à paz que pode ser conseguida pela consciência ajustada às respostas definitivas substituem-se a dúvida continuamente renovada e a ansiedade desesperadora. (...) E a marginalidade a que a sociedade normalmente relega a criatura que não se conforma a seus padrões, só serviria, é claro, para apressar essa destruição" (p. 242 - grifos meus) Acerca do ajustamento do indivíduo ao grupo e da "concepção paroquial" da existência, o autor dizia que "tão temível quanto o despotismo central, é aquele que as comunidades exercem sobre os indivíduos, quando se vêem constrangidos a aderir aos valores comunitários impostos ou então a conformar-se com a marginalidade como única saída, por se recusarem à mediocridade da vida. Um dos resultados mais lamentáveis em se querer trazer o outro para as suas certezas e integrá-lo num grupo identificado pelas mesmas verdades aceitas, é considerar o que se recuse a se integrar como um ser estranho. Em matéria educativa, o ideal é a formação de personalidades autônomas. É no pequeno grupo que se encontra a liberdade individual e o sentimento de aceitação como pessoa, e ninguém ignora que um grupo é um modelo de vida" (p. 243). Na ocasião, o autor criticava os cursos universitários que, dotados de autonomia, transfiguravam-se no seu contrário, em heteronomia, instalando o que ele denominou por "gruponomia" como técnica didática, como "tendência a se tornar um fim em si mesma, esquecendo dos outros objetivos da escola, como ensinar cálculo, por exemplo". Ele fazia uma crítica a alguns institutos da USP que estavam

\footnotetext{
${ }_{71}$ VILLALOBOS, João Eduardo. "Dinâmica de grupo e educação" RBEP, no 123, jul./set. 1971, p. 242 245.
} 
adotando esse modelo. Desta forma, a "marginalidade seria um castigo para quem duvidasse, eliminando as personalidades independentes" (p. 245).

\subsection{A FELICIDADE: UM DIREITO OU UMA OBRIGAÇÃO?}

Assim como a caridade e a civilidade, a felicidade também apareceu nos textos examinados como algo necessário à convivência social. Quase como uma obrigação, seria preciso "ser feliz" e, para tanto, a moralização também poderia contribuir. Parece que seria preciso aprender a "ser feliz", contentando-se com aquilo que seria considerado adequado para trazer a felicidade. Na perspectiva de alguns autores que escreveram livros e artigos no período examinado, realizações "nobres", que envolveriam principalmente o bem-estar coletivo, seriam as responsáveis por despertar tal sentimento. O educador Fernando Tude de Souza ${ }^{72}$, em artigo publicado na RBEP em 1954, no qual discutia uma "crise dos valores morais" pela qual estaria passando o país, dizia que as "falhas educacionais" estariam no cerne do problema: "marchamos para o caos se não cuidarmos da educação do povo". (p. 212) O autor defendia que toda educação deveria buscar a implementação de valores "espirituais e morais" na vida dos cidadãos. Dentre estes valores estava a "busca da felicidade": "felicidade não é apenas exuberância, excitação e conforto material. Prazeres temporários ensejam alívio para os aborrecimentos e responsabilidades, mas felicidade é muito mais que um mero sumário de prazeres. Embora a felicidade dependa de muitas coisas materiais, a felicidade duradoura depende, em grande parte, de profundas qualidades pessoais e da afeição e do respeito dos outros. Isto requer esforço e sacrifício. A escola pode orientar o trabalho da busca da felicidade: fornece o alimento espiritual e inspira as mais nobres realizações." (p. 215) Enquanto Souza defendia que a "busca da felicidade" requeria sacrifício visando o bem da coletividade, o professor Faria Netto ${ }^{73}$, em artigo publicado na RP em 1960, acreditava que a felicidade, entendida como a "edificação do

\footnotetext{
${ }^{72}$ SOUZA, Fernando Tude de. (O Jornal, Rio) "A crise dos valores morais e os educadores" RBEP, $\mathrm{n}^{\circ}$ 56, out./dez. 1954, p. $212-215$.

${ }^{73}$ FARIA NETTO, F. de. “A educação bandeirística”, RP, Out., 1960, p. 28 - 29.
} 
ser", seria alcançada pelos indivíduos se, na escola, as vocações fossem trabalhadas e orientadas. Para tanto, defendia o "bandeirismo educativo", que deveria "superar as experiências da vida que pertencem à área das sutilezas espirituais" (p. 28). O "bandeirismo educativo" ocorreria em institutos "plurieducacionais", e estes não negligenciariam "a felicidade do ser humano (...) no princípio de sua ação escolar, o trabalho adequado ao seu dom." (p. 29) Também se referindo à formação para a felicidade, Luiz Alves de Mattos, no livro Sumário de didática Geral, na reedição de 1967, dizia que as escolas teriam a responsabilidade de formar "ideais e atitudes", dentre eles estariam os "ideais de vida sadia e feliz para si e seus semelhantes; de civismo, respeito às leis e problemas coletivos; ideal moral, justiça, solidariedade, respeito aos direitos dos outros". (p. 110) Desta forma, assim como a educação moral poderia ensinar as pessoas a se comportarem e a se conterem, ela também poderia ensiná-las a "ser feliz", condicionando os seus desejos e formando a sua vontade. Ser feliz era quase tão necessário quanto ser saudável e ser "normal". A representação das pessoas felizes trazida pelas fontes consultadas evidencia que as pessoas deveriam ser formadas para desejar a vida familiar e também o trabalho, para poder sustentá-las, para atender minimamente a um padrão de consumo e para poder cumprir com os seus deveres cívicos, servindo ao outro e à pátria, e alegrando-se com isso. Estar quite para com esses deveres traria a felicidade. Assim, a representação da "felicidade" na literatura pedagógica examinada estava mais relacionada a uma obrigação do que a um direito, consistindo num elemento necessário à moralização dos indivíduos.

\subsection{A FORMAÇÃO DO CARÁTER E A LUCIDEZ EM TORNO DE SI}

Nas escolas públicas, a conduta moralizada era expressão de virtude, virtude esta que a educação escolar procurava alcançar em cada indivíduo. Do ponto de vista da moral, a virtude aparece como uma espécie de renúncia. A prática da moral devia trazer à consciência as tendências egoístas e instintivas mais fortes que se disfarçavam e dissimulavam para, em seguida, lutar contra elas. A moral inculcada exige uma certa lucidez em torno de si mesmo, implicando num esforço vigoroso, e por vezes doloroso, 
contra si por se obrigar a renunciar àquilo - paixões, desejos, vontades - que um julgamento pessoal comandou. A busca da virtude, do valor pessoal, gira em torno da conquista de si, evidenciada pela formação do caráter. Mediante o exame das fontes consultadas para o desenvolvimento deste estudo, foi possível perceber que havia, por parte da educação escolar, um esforço no sentido de formar o caráter dos alunos, a partir de valores como: esforço, obediência, resistência, coragem, perseverança, busca pela verdade, solidariedade, respeito aos outros. Tais valores poderiam consistir na essência dos discursos acerca da moral enunciados nas escolas, a partir do quais se pretendia conduzir o comportamento tanto dos professores quanto dos alunos. Em 1952, o boletim ${ }^{74}$ da Comissão Brasileira-Americana de Ensino Industrial ${ }^{75}$ (CBAI) publicado na RBEP, ao tratar da educação liberal dizia que o homem deveria ser entendido em seus aspectos biológico, psicológico, moral e espiritual e também como "membro de uma família, de uma coletividade nacional e internacional" (p. 297). As pessoas deveriam ser formadas para entender e apreciar "obras de arte, éticas e religiosas", para serem "úteis", livres e responsáveis pela coletividade a qual pertenceriam, e também dotadas de grande capacidade de integração. Virtudes e hábitos de vida, como cooperação, liberdade pessoal e responsabilidade social, entendidos como essência do caráter moral, seriam requisitos indispensáveis para o "autogoverno político e cimento da vida democrática", para tanto, seria preciso "cuidar do caráter, do corpo e da mente" (p. 299). Neste texto, o caráter é concebido como um conjunto de hábitos e de atitudes morais, que se desenvolve especialmente nos primeiros anos de vida no lar, na igreja e na coletividade e continua a ser modelado mediante a disciplina e a experiência de uma educação formal. O boletim sugere que os alunos devam "aprender a lição de humildade que ensina a religião. Companheirismo, cooperação espontânea, devoção e sacrifício” (p. 300).

Em artigo publicado na RBEP, em 1953, a professora americana Esther Lloyd Jones $^{76}$, da Universidade de Columbia, dizia que nos EUA o aumento da educação

\footnotetext{
${ }^{74}$ Boletim da CBAI, Rio. (Através de Revistas e Jornais) "Significado da educação liberal" RBEP, $\mathrm{n}^{\circ}$ 48, out./dez. 1952, p. $296-304$.

${ }^{75}$ Comissão Brasileira-Americana de Ensino Industrial (CBAI), instituição criada em 1946 e extinta em 1962. Sediada inicialmente no Rio de Janeiro e, a partir de 1957, em Curitiba, a Comissão traduziu livros e promoveu cursos de aperfeiçoamento para professores, no Brasil e nos EUA.
}

${ }^{76}$ JONES, Esther Lloyd. “A orientação como ensino em profundidade” RBEP, n 51, jul./set. 1953, p. 58 72. 
universal não registrava um correspondente progresso na cultura política, social e moral, chamando a atenção para a necessidade de se cultivar o caráter e as qualidades afetivas da juventude. Para a autora, "o problema essencial dos nossos dias é a relação homem com o homem. Se compreendermos como se desenvolve o caráter e a personalidade saberemos utilizar esse conhecimento para criar uma humanidade melhor" (p. 71). Em artigo publicado na RBEP em 1959, o médico Gonçalves Fernandes ${ }^{77}$ cita Pestalozzi ao falar sobre as crianças: "suas necessidades corporais são a base de suas forças; conduzem simplesmente, e em linha reta, ao duplo fundamento da verdadeira sabedoria humana e da virtude ao reconhecimento e ao amor, que é a base de toda a moralidade humana" (p. 136). Segundo o autor, na infância é que se podem corrigir os distúrbios da conduta e do caráter e "não existe neurose no adulto que não tenha raízes numa primo-neurose infantil" (p. 137). Nos estudos desenvolvidos em higiene mental, afirma Fernandes, considera-se a "normalidade mediana do comportamento ideal. Tal normalidade, mediana, é constante em função de um grupo social e da sua moral-cultural. A normalidade ideal, esta poderá variar de indivíduo para indivíduo" (p. 146).

Em artigo intitulado "Caráter", publicado na RP em 1958, Alberto Ferreira Giúdice $^{78}$, diretor de grupo escolar no interior do Estado de São Paulo, afirma que a educação escolar "sempre descuida um pouco dessa faceta importantíssima: formação do caráter do educando. Alunos aprovados mas sem caráter firme são o reflexo da errônea didática" (p. 11). Além de responsabilizar a "errônea didática" que, por ser demais condescendente às falhas dos alunos acabava por descuidar de sua formação moral, o autor também afirma que as famílias não estavam educando adequadamente as crianças: "a escola deve formar o caráter porque isso não foi feito em casa como deveria" (p. 11). O autor é enfático ao afirmar que, se a criança "tem uma mãe depravada, se não encontrar quem lhe guie os passos, fatalmente se tornará também depravado. (...) A esposa ou mãe é responsável pela formação do caráter dos filhos, porque sua atitude irá influir na vida do marido, chegando a trazê-lo a um bom caminho se preciso" (p. 11) Na falha da tarefa da mãe em formar o caráter de seus filhos, caberia aos professores "cuidar com zelo de todos

\footnotetext{
${ }^{77}$ FERNANDES, Gonçalves. "Higiene mental escolar" (inicialmente publicado em Revista de Ensino, Porto Alegre) RBEP, no 73, jan./mar. 1959, p. 135 - 147.

${ }^{78}$ GIÚDICE, Alberto Ferreira. “Caráter” RP, nº 40, jul./1958, p. 11.
} 
que lhe forem confiados" (p. 11) Em outro artigo, publicado na RP em 1960, Giúdice ${ }^{79}$ afirmava que pouca atenção vinha sendo dada, nos estabelecimentos de ensino primário, ao ensino de civilidade, de civismo e de educação moral e cívica. Para ele, pais e mestres tinham responsabilidade por isso: "hoje ocorre sério descaso quanto a essas disciplinas. As crianças obtêm diploma do ensino primário, mas não sabem se comportar como homens em qualquer parte de um meio civilizado. Se para ser moderno é preciso ser mal educado, então é preferível ser antiquado. O caráter se modela mais facilmente quanto mais jovem for o indivíduo" (p. 12) O "Decálogo do professor", do educador argentino José Berrutti ${ }^{80}$, publicado na RP em 1959, também considerava "indispensável formar a consciência moral da criança” (p. 12). Para a professora Cinéa Vieira Ramos ${ }^{81}$, em artigo publicado na RP em 1959, é importante que a escola primária ensine "a criança a trabalhar com método e proveito, só dentro da ordem, da disciplina é que atinge esse objetivo. O homem indisciplinado não tem caráter e a formação do caráter constitui o centro de toda atividade escolar. A imobilidade, o silêncio na classe não é verdadeiramente disciplina. É a atividade negativa que se defronta com os modernos princípios da Escola Nova. Disciplina é dinamismo, ação compreensiva e inteligente" (p. 10)

O professor Francisco Pássaro ${ }^{82}$, em artigo publicado na RP em 1961, dizia que aos pais e aos professores cabia preparar as crianças para as obrigações da vida. Segundo ele, "a pedagogia moderna forma em torno do aluno um ambiente que se amolda ao seu desenvolvimento, respeitando as sua características físicas e psíquicas. A educação antiga, passiva, deu lugar à ativa, cujo intuito é preparar para a vida. Faltando essa diretriz, a moralidade da educação será desviada” (p. 33). O caráter deveria ser edificado em princípios retos e firmes pois "o caráter é a linha reta entre os atos e as convicções”. O autor afirma não partilhar das idéias de Rousseau e Tolstoi, que acreditam que as crianças nascem boas. "Uma íntegra modalidade de educação, porém, produz uma humanidade ideal. Diariamente deparamos com criaturas imperfeitas: as provas de egoísmo,

\footnotetext{
${ }^{79}$ GIÚDICE, Alberto Ferreira. "Ponto alto que se tornou ponto baixo" RP, jul./1960, p. 12.

${ }^{80}$ BERRUTTI, José. “Decálogo do professor” RP, dez./1959, p. 28.

${ }^{81}$ RAMOS, Cinéa Vieira. “A disciplina na escola” RP, dez./1959, p. 9 - 10.

${ }^{82}$ PÁSSARO, Francisco. “A criança, esperança da pátria, nos aspectos educativos” RP, mai./jun., 1961, p. 32 -33 .
} 
arbitrariedade, desonestidade, enchem os processos, os relatórios da polícia. Por aí vemos o descuido da educação infantil, evoluindo na adolescência” (p. 32). Contrário aos castigos físicos, por embrutecerem as crianças, Pássaro afirma que "a educação tem por escopo adaptar o espírito infantil para a existência, o que quer dizer, para a sociedade. Nada de rigor extremo: a criança se disciplina pela liberdade e pelas reações naturais" (p. 33).

\subsection{OS PAPÉIS QUE CABERIAM AOS HOMENS E ÀS MULHERES}

Durante a procura das referências acerca da moralização na escola nas fontes examinadas, foi possível encontrar artigos que, ao tratar em algum momento da formação moral, acenavam para a importância de se ensinar, na escola, quais papéis caberiam aos homens e às mulheres representar na sociedade. O texto ${ }^{83}$ sobre a "XV Conferência Internacional de Instrução Pública", realizada em Genebra e promovida pela ONU e pelo Bureau Internacional de Educação, publicado na RBEP em 1953, também tratou da importância do acesso das mulheres à educação. De acordo com o artigo, uma educação de caráter geral não poderia ajudar as mulheres a se ajustarem ao seu papel essencial na família e na sociedade e a desenvolver ao mesmo tempo suas aptidões especiais. A formação moral e cívica e a formação para a vida familiar deveriam ser incluídas em todos os programas de "educação da mulher, e do homem, a fim de lhes fazer compreender e assumir o papel da mulher no plano familiar, local, nacional e internacional" (p. 98). Robert Havighurst ${ }^{84}$, pesquisador do INEP, em artigo publicado na RBEP em 1957, dizia que a escola poderia colaborar com tarefas que ajudassem na aquisição de uma consciência moral e na formação de uma escala de valores. Acerca do desempenho de um papel masculino ou feminino: a "tarefa" que caberia à educação escolar seria a fazer com que as crianças aceitassem o "papel de adulto masculino ou feminino, tal como a sociedade o define e aprova". (p. 136) Neste mesmo ano, um informativo ${ }^{85}$ acerca dos Estados

\footnotetext{
83 "XV Conferência Internacional de Instrução Pública", realizada em Genebra e promovida pela ONU e pelo Bureau Internacional de Educação. RBEP, n 49, jan./mar. 1953, p. 92 - 99.

${ }^{84}$ HAVIGHURST, Robert J. "Tarefas evolutivas das crianças e dos adolescentes" RBEP, $n^{\circ}$ 67, jul./set. 1957 , p. $130-143$.

85 “São Paulo” RBEP, nº 65, jan./mar. 1957, p. 186 - 196.
} 
brasileiros, publicado na mesma revista, dizia que, em São Paulo, a escola não preparava os alunos para o bom desempenho dos deveres sociais, e afirmava: "nos lugares mais afastados, onde só caiba uma escola, mais vale que ela seja entregue a uma mulher. Mais vale educar as meninas de um bairro, que os meninos. Não esqueçamos Laboulaye ${ }^{86}$ : "Educar um homem, é educar um indivíduo; educar uma mulher é educar uma geração."” (p. 193 - grifos meus) Já em 1976, o professor espanhol Manuel Pallarés ${ }^{87}$, em artigo publicado na RBEP sobre o desenvolvimento infantil, dizia que, dentre as tarefas evolutivas da primeira infância (até 5 anos), estaria a de conhecer as diferenças e a modéstia sexual. Entre os 5 e os 9, as crianças precisariam aprender o "papel apropriado masculino e feminino"; desenvolvendo a consciência, a moralidade e uma escala de valores, que seriam orientadas culturalmente. De acordo com o autor, o crescimento constituiria, em parte, em adaptação social determinada pelas expectativas dos adultos, que por sua vez estariam em conformidade com diretrizes culturais da sociedade da época: "as condutas que satisfazem diretamente as necessidades são condutas adaptativas e a planificação educativa segundo as tarefas evolutivas favorecerá a adaptação sadia da criança" (p. 554).

As representações do ideal do indivíduo devidamente moralizado ou não, veiculadas tanto nos periódicos educacionais quanto nos manuais pedagógicos, associavam a pobreza aos vícios e a riqueza às virtudes. A escola era vista como a instituição que teria o poder de redimir as crianças pobres do mal advindo de sua origem e os professores, concebidos como os "salvadores", deveriam realizar o seu trabalho mediante quaisquer condições, não importa as dificuldades que tivessem. De acordo com os discursos veiculados nas fontes consultadas, ainda é possível depreender que a busca e a cultura do valor pessoal pela formação do caráter conduziriam o indivíduo a moldar a sua personalidade, levando ao conhecimento, à conquista de si mesmo e à "verdadeira liberdade", de que tanto falaram os autores, especialmente quando movidos pelos ideais escolanovistas, o que pode ser entendido como a maestria de si, ou também como a autonomia moral. Essa autonomia, da moral sobre o indivíduo, consiste em fazer com que

\footnotetext{
${ }^{86}$ Édouard de Laboulaye (1811 - 1883) foi um jurista, poeta e escritor francês.

${ }^{87}$ PALLARÉS, Manuel. “Conduta social e adaptação na idade pré-escolar” RBEP, n ${ }^{\circ}$ 140, out./dez. 1976, p. $540-555$.
} 
a conduta de cada um seja dirigida pela própria reflexão e pelo próprio julgamento, prevalecendo a razão. A personalidade inteira deveria se engajar na ação moral, controlando os desejos e comandando o corpo. Tal engajamento, ao orientar a conduta, afirmaria sua autonomia e liberdade, transformando em prática a educação moral. Influenciada pela Escola Nova e pelos métodos ativos, a educação moral seria aprendida através da prática, "a fazer, fazendo", mas também observando e convivendo com exemplos que deveriam ser seguidos. Nas escolas primárias, caberia aos professores, e especialmente às professoras representar esse papel, como será visto no capítulo seguinte. 


\section{Capítulo 2}

\section{ARAUTOS DA MORAL, DA DECÊNCIA E DAS VIRTUDES: AS PROFESSORAS PRIMÁRIAS COMO EXEMPLO DE CONDUTA}

"Ser professor não é dar três ou quatro horas de aulas, e depois despir-se da Responsabilidade, para envergar a descorada indumentária da Vulgaridade...; - mas sim, manter a seqüência da sua função educativa. O professor deve sempre cumprir seu dever, pouco importando se há ou não reconhecimento, ou se os colegas procedem ou não corretamente. Ser professor, não é após a Efetivação, fazer da Remoção e Aposentadoria, o Alfa e Ômega da existência; - mas sim, revelar durante os sessenta segundos de cada minuto e nos sessenta minutos de cada hora, - a Elegância e a Riqueza Espitirual!..." ${ }^{\text {" }}$ A citação é do professor José de Lima, extraída de artigo publicado na RP em 1962. Subordinados perante seus superiores, os professores, especialmente as professoras primárias, eram vistos como exemplo importante a ser seguido pelos alunos. Apesar de grande parte dos textos fazer referência aos docentes do magistério primário através do genérico masculino "professor", é especialmente às professoras que se refere este trabalho. Em 1964, 93,4\% das 289865 pessoas filiadas ao magistério primário no Brasil eram mulheres $^{89}$. Segundo Luiz Pereira (1969), o tipo social professora realiza-se predominantemente através do magistério primário: em 1950, das 140525 professoras brasileiras, 104348 lecionavam em escolas primárias. Tal situação se deve às possibilidades que o magistério primário oferecia à acomodação e à integração entre papéis domésticos e profissionais. Recrutadas nas camadas socioeconômicas médias, as normalistas teriam a possibilidade de exercer a profissão em um período do dia e de dedicar-se à família e às tarefas domésticas em outro. Nos anos de 1960, apesar de se apresentar como uma das mais bem sucedidas modalidades de participação das mulheres na população economicamente ativa, o ordenado para o exercício do magistério primário seria insuficiente para o sustento da família, resignando às moças recém-formadas uma posição de dependência financeira. Contudo, cursar a escola normal trazia suas

\footnotetext{
${ }^{88}$ LIMA, José de. "Ser professor...", RP, Mar./Mai.,1962, p. 29.

${ }^{89}$ PEREIRA, Luiz. O magistério primário numa sociedade de classes São Paulo: Pioneira, 1969.
} 
recompensas, se não materiais, ao menos sociais e simbólicas: "ao lado da função técnicoprofissional, as escolas normais funcionam como 'colégios para moças', dado que ponderável parcela de sua clientela se destina exclusivamente ao padrão doméstico, via casamento. Tendo em vista esse contingente, aquelas instituições preparam certo tipo de mães e donas de casa que, através da frequiência às escolas normais, vêm a participar de determinados complexos da herança cultural não acessíveis por enquanto à maioria das mulheres, devido a barreiras sobretudo econômicas.” (p. 67) De acordo com o autor, as escolas normais apareceriam como "agências de modernização dos papéis maternos", imprimindo um caráter científico aos aspectos técnicos dos cuidados com as crianças, daí a ênfase desempenhada pela psicologia no currículo destas instituições.

$\mathrm{Na}$ condição de agentes socializadoras, as professoras primárias deveriam também educar pelo exemplo, através do porte e das atitudes demonstradas aos alunos. Para promover a formação da personalidade dos educandos, as professoras deveriam cultivar algumas atitudes, tais como: "entusiasmo e alegria no trabalho, naturalidade e delicadeza, habilidade, clareza, voz adequada e linguagem ao alcance dos alunos", segundo o professor Alberto Bruno Giongo ${ }^{90}$, essas são "atitudes que o mestre deve primar em possuir e cultivar." (p. 29) Os professores deveriam possuir um linguajar correto e empregar corretamente as normas da gramática na vida cotidiana. Além disso, o tom de voz empregado pelos professores, dentro ou fora da escola, também deveria obedecer a certas regras, porque, afinal, como dizia José de Lima ${ }^{91}$, os professores não deveriam chamar a atenção na rua porque "ser professor não é conversar em alta voz, na rua ou em conduções, chamando para si, estultamente, a atenção dos circunstantes; - mas sim, conhecer (e tê-la como norma) a observação erudita de Schopenhauer: 'O barulho e azáfama, produzida por uma pessoa, é inversamente proporcional à sua inteligência'; isto é, quanto mais idiota é um indivíduo, mais ele se diverte (e acha bonito) em assobiar, cantarolar e tamborilar com os dados em lugares públicos..." (p. 29) Como se fossem incumbidos por uma missão, os professores deveriam cultivar qualidades quanto ao físico e quanto à alma. Neste aspecto, o magistério primário teria muito em comum com a vida militar e com o sacerdócio. Com o movimento de expansão, as escolas primárias passaram a receber uma clientela de origem indiscriminada e o papel desempenhado pelos professores, aos receber alunos que traziam

\footnotetext{
${ }^{90}$ GIONGO, Alberto Bruno. “A orientação educacional e o professor”, RP, jul./1959, p. 29.

${ }^{91}$ LIMA, José de. "Ser professor...”, RP, Mar./Mai.,1962, p. 29.
} 
não apenas capital cultural diverso, mas também maneiras distintas de agir e de se comportar no espaço público, exigia mais de sua ação pessoal, que não deveria se restringir ao ensino e à transmissão do conhecimento. Em todas as atividades escolares, a ação educativa dos professores seria fundamental e a sua personalidade poderia exercer uma influência profunda e durável sobre o comportamento dos alunos. Pela força do exemplo, por uma vida moral irrepreensível e apresentando uma conduta na qual os alunos pudessem se inspirar, caberia aos professores ter uma vida pública e privada impecáveis. Diante dos alunos, através da correção de seus trajes e da retidão do seu comportamento, os mestres deveriam levar os outros a dominar a si mesmos. Por serem as crianças muito sensíveis à autoridade docente, a personalidade dos professores seria umas das qualidades que ajudariam a criar, nas escolas, uma atmosfera de confiança, desejável à preparação dos alunos para a vida moral e social.

Para o professor Francisco Pássaro", autor do artigo intitulado "A criança, esperança da pátria, nos aspectos educativos”, publicado na RBEP em 1961, Os atos dos educadores devem partir de suas convicções e os exemplos valem mais do que a doutrina. "O essencial não é exaltar a verdade, mas o é praticá-la; não é preceituar as normas dos deveres, mas cumpri-las. O educador, para merecer as honras de educador, consubstanciase na autoridade moral e esta só se firma pela idoneidade, sem a qual não aufere direito a ser obedecido e respeitado. Aquele que pensa ser um mestre mas humilha direta ou indiretamente o aluno; aquele que se julga com o direito de educar mas suas ações não espelham as persuasões íntimas; aquele que se diz professor mas seu espírito tem volúpia pelo dinheiro, caiu também no caos inextricável do complexo de inferioridade. As formações devem ser superiores e retilíneas, porque os desígnios são elevados, nobres. Disso tudo resulta a afetividade sincera entre mestre e discípulo, como desejou Pestalozzi. As relações se cimentam no ritmo da prosperidade. Assim, o sagrado dístico de nossa Pátria, 'Ordem e Progresso', tornar-se-á, cada vez mais, inconfundível” (p. 33).

O trabalho docente, enunciado muitas vezes nas fontes consultadas como uma "missão", assemelhava-se ao sacerdócio. Uma espécie de sacerdócio laico. No exercício de sua profissão, parece que seria indispensável aos professores um idealismo que teria a

\footnotetext{
${ }^{92}$ PÁSSARO, Francisco. “A criança, esperança da pátria, nos aspectos educativos”, RP, Mai./Jun., 1961, p. $32-33$.
} 
virtude como sua marca, no sentido de melhorar e elevar a condição humana. Após a escolha pela carreira, e para muitos não se tratava simplesmente de uma escolha, mas sim da profissão (para muitos talvez a única) possível, esperava-se verdadeira devoção. Em artigo publicado na RP em 1960, intitulado “A missão do professor”, o professor Acácio de Vasconcelos Camargo ${ }^{93}$ dizia que o docente trabalhava com amor e carinho por uma única recompensa: a tranqüilidade da própria consciência. Exercendo a sua profissão, os professores prestavam um grande serviço ao Estado, à sociedade e à Pátria. Para influenciar a conduta dos alunos, "o professor deve dar o exemplo de bons costumes e moldar sua linguagem em um padrão de pureza, elevação e brilho. Ainda mais, o educador deve ser alegre, pois, a alegria resume sensação de força para o trabalho. As tristezas e os tropeços da vida devem ser deixados em casa, pois os bons modos, as palavras cautelosas do educador iluminam a inteligência do educando, predispondo-o à obediência e ao necessário aprimoramento intelectual e afetivo." (p. 15) Revestidos de poderes conferidos pelo lugar que ocupavam, os professores deveriam ensinar pelo exemplo e pela ação, influenciando os alunos na maneira de pensar e de agir. Segundo o professor universitário Abgar Renault ${ }^{94}$, em artigo publicado na RBEP em 1953, a justiça é o primeiro dever moral do professor. Para o autor, o excesso de solicitações de natureza material ou física não deixaria margem para o exercício da "inteligência e o cultivo da vida interior", inclusive religiosa. "A vida puramente corporal dissipa os tesouros do espírito. O espírito, despovoado, estéril e nulo, acaba por vingar-se; esse é o ponto crucial da situação do ensino brasileiro". (p. 3) Renault defende que a educação, como instrumento de “construção das nacionalidades", deveria promover a transformação das pessoas. O autor cita Santo Agostinho: "a nós, não a eles, é que devemos transformar". (p. 18)

Para o professor Orlando Silveira Martins ${ }^{95}$, em artigo publicado na RP em 1963, "os professores devem ter o espírito de liderança para bem lidar com os pais, alunos, grupo social, etc., onde vão exercer as suas atividades. Todos os problemas que surjam no meio em que atuam, serão seguramente resolvidos, se imbuídos das características do líder e se

\footnotetext{
${ }^{93}$ CAMARGO, Acácio de Vasconcelos. “A missão do professor”, RP, n 57, ago./set. 1960, p. 15.

${ }^{94}$ RENAULT, Abgar. “A crise do ensino”, RBEP, n 50, abr./jun. 1953, p. 3 - 19.

${ }^{95}$ MARTINS, Orlando Silveira. “Liderança”, RP, Jul./Set., 1963, p. 38.
} 
for do tipo democrático." Irene Mello Carvalho ${ }^{96}$, diretora da divisão de ensino da Fundação Getúlio Vargas, em artigo publicado na RBEP em 1959, também defendia que os membros do magistério deveriam ser líderes. O problema da disciplina se manifesta por atitudes de convívio social. $\mathrm{O}$ meio e as instalações interferem positiva ou negativamente. Para ela, os hábitos e as atitudes desenvolvidos no ambiente doméstico no qual viviam as crianças poderiam ajudar ou prejudicar o comportamento disciplinado das crianças. Mas, para tanto, o elemento decisivo seria a personalidade dos professores porque "alguns professores são líderes e têm como atributo: energia física, caráter (no sentido moral), coragem, decisão, cordialidade, intuição psicológica. Os mestres autoritários agem com a coação, sob a ameaça de castigos físicos ou morais, ao contrário dos líderes, que agem com o espírito democrático. O professor que ama a juventude sente o apostolado da sua tarefa educativa e dificilmente perde o autocontrole. Em face ao aluno rebelde, encontra meios ditados pelo coração ou pela inteligência.” (p. 150) Evocando a didática não-diretiva e a teoria de Carl Rogers, a professora universitária Lydinéa Gasmann ${ }^{97}$, em artigo publicado na RBEP em 1971, apresentou o comportamento dos docentes sob outra ótica: ao invés de líderes, os professores deveriam interagir com os alunos, para que, então, eles pudessem se auto-dirigir. Para a autora, a teoria rogeriana seria bem diferente da tentativa de "matematizar" o comportamento humano, reduzido-o a esquemas. Nela, o indivíduo seria capaz de se auto-dirigir e os professores deveriam ter personalidade "mais receptiva". Aprender seria confrontar-se com o outro, tomando consciência do seu valor, em contato com os professores: "enquanto a didática sugere técnicas, a didática não-diretiva sugere e orienta atitudes. A atitude não-diretiva não é um método de ensino, é um estilo de relação com o outro e com o grupo.” (p. 410) Gasmann apresentou as seguintes características que deveriam ter os professores "não-diretivos": “condutor, elucidador e informador. Orienta, dialoga. O professor deve ser participante e não espectador, possibilita um clima permissivo que faz com que o grupo se mobilize e se auto-dirija, evitando a dependência. Sua eficácia depende da personalidade do professor. $O$ fatores que mais impedem o funcionamento do grupo são as questões de individualismo e de liderança.” (p. 420) Mesmo privilegiando a relação entre os professores e os alunos em detrimento da posição

\footnotetext{
${ }^{96}$ CARVALHO, Irene Mello. "Disciplina e liderança" (Escola Secundária, Rio), RBEP, nº 73, jan./mar. 1959 , p. $147-152$.

${ }^{97}$ GASMANN, Lydinéa. "Possibilidade de uma didática não-diretiva: teoria de Rogers e didática", RBEP, ${ }^{\circ}$ 124, out./dez. 1971, p. $408-420$.
} 
de liderança que os professores pudessem ocupar e, desta, forma influenciar o comportamento dos alunos, a eficácia com relação ao ensino e à aprendizagem, continua a depender da "personalidade do professor". Se a eficiência educativa dos mestres dependia da sua personalidade, a aula seria então uma combinação de comportamentos dos professores, cujo “objetivo sempre será o aluno na tríplice relação de fazer, saber, ser - que equivale às metas pedagógicas da ação, informação e formação". Este é o ponto de vista do inspetor escolar Sá Teles ${ }^{98}$, que defendia a aprendizagem pela ação, em artigo publicado na RP em 1960.

A influência da psicologia nos discursos veiculados nos periódicos a partir dos anos de 1970 foi marcante. Os professores continuavam a ser vistos como exemplos importantes que deveriam ser seguidos pelos alunos, mas as suas condições emocionais e a sua personalidade passaram, gradativamente, a ser objeto de maior atenção. Em 1971, Maria Helena Novais Mira ${ }^{99}$, professora universitária, publicou um artigo na RBEP intitulado “Condições emocionais para o exercício do magistério". A autora define a personalidade como uma "síntese individual e dinâmica que integra experiências vitais", daí a influência das condições emocionais dos professores em seu "ajustamento profissional". As dificuldades de adaptação dos professores ao trabalho seriam decorrentes de atitudes de isolamento ou passividade, provindas de "situações de vida conflitivas". Os padrões de conduta desejáveis à docência seriam construídos partindo de "determinantes internos e externos" do comportamento. Caberia aos professores zelar pela sua saúde mental para garantir também a saúde mental dos seus alunos. Mira faz uma crítica à idéia de professor ideal, que chama de "protótipo de professor”: “(...) Não há suficientes santos para preencher todas as funções do magistério, por isso os seres humanos imperfeitos também podem levar a cabo essa tarefa gloriosa, que é a educação dos indivíduos, assim o que vai contar não são as suas qualidades ou os seus defeitos, mas o que faz com eles em favor dos alunos." (p. 301 - grifos meus) Para a autora, a magistério poderia desencadear tendências neuróticas devido ao desgaste emocional contínuo: "alguns pensam que o magistério deve ser um sacerdócio, sem direito a preocupações pessoais. O professor também tem

\footnotetext{
${ }^{98}$ TELES, Sá. "Da técnica docente”, RP, jun./1960, p. 28.

${ }^{99}$ MIRA, Maria Helena Novais. "Condições emocionais para o exercício do magistério", RBEP, no 124 , out./dez. 1971, p. $299-305$.
} 
problemas psicológicos" (...) ao tentar "corresponder a uma imagem idealizada, o professor sente-se inseguro, perseguido e vulnerável. O conhecimento de si é imprescindível para uma ação eficaz”. (p. 302) A psicologia comportamental de Rogers também é citada por essa autora. Neste caso, o comportamento dos professores é objeto de atenção porque dele dependeria o comportamento das crianças e dos jovens sob sua responsabilidade: se ele fosse ansioso, por exemplo, ele "desorganizaria o comportamento dos alunos". Os atributos pessoais desejáveis aos docentes seriam: paciência, tolerância, honestidade, humildade, dedicação, etc. Contudo, diz a autora, "tais qualidades só funcionarão se existirem condições emocionais que possibilitem o ajustamento psicológico do professor e o seu relacionamento adequado com os alunos. $\mathrm{O}$ equilíbrio está ligado à maturidade afetivoemocional, à estrutura da personalidade e aos condicionamentos ambientais. Muitos professores não têm condições psicológicas necessárias para um bom equilíbrio emocional, por serem personalidades comprometidas por conflitos graves, afetivo-sexuais, imaturas ou ainda patológicas. É preciso controlar as emoções. Um professor bem equilibrado emocionalmente é: seguro, não tem atitudes defensivas com os alunos, coerente, autocrítico, autoconfiante, etc." (p. 305 - grifos meus)

Nos anos de 1950, com a consolidação da vida urbana e o desenvolvimento industrial, as relações humanas sofriam alterações e o medo que os valores, especialmente com relação à preservação da família como instituição, fossem abalados por tais transformações estava presente nos discursos dos pedagogos. A anarquia e o comunismo também causavam pavor naqueles que defendiam os ideais democráticos. Anísio Teixeira ${ }^{100}$, em artigo publicado na RBEP em 1958, referiu-se à situação social como "lei da selva", que limitava a liberdade individual, ampliava a desigualdade de classes e gerava injustiça e desordem. Temendo pela ascensão do comunismo e considerando que "sempre que recusa crer na possibilidade do seu triunfo pacífico, pela persuasão e pela razão, deposita sua fé nos meios de doutrinação e de força", Teixeira defendia que o "comunismo somente seria aceitável se aceitasse os métodos da razão e da persuasão socialista.” (p. 14) Buscando contornar tal crise social, o autor sugeria a ampliação da área do saber de natureza científica ao campo da economia, da política e da moral. Os professores e as escolas seriam os pioneiros na fronteira de progresso moral que teria de ser aberta daquele

${ }^{100}$ TEIXEIRA, Anísio. "Variações sobre o tema da liberdade humana”, RBEP, nº 69, jan./mar. 1958, p. 3 18. 
momento em diante, "na conquista do poder não só material mas humano sobre a vida no planeta. Professores de civilização: reaprender o sentido do termo, e fazer-se mestre da candura, da urbanidade e da tolerância." A partir dos anos de 1950, a situação sócioeconômica aliada ao fator da expansão do ensino público, exigia, cada vez mais, que relações de mando e de subordinação fossem aprendidas na escola. Disciplinar os indivíduos que estavam ali envolvidos, professores e alunos, mediante o viés do autogoverno, era uma tarefa que deveria fazer parte da vida escolar. Em 1957, um "Encontro de Educadores do Vale do Paraíba""101, relatado na RBEP, dizia que nenhum professor ou funcionário deveria estar alheio às preocupações com a educação moral e cívica: "cada professor deverá dar, com a sua conduta, o melhor exemplo para a formação social do educando. A escola desenvolverá atividades sociais que propiciem ao educando a oportunidade para o exercício das qualidades de auto-governo". (p. 196)

A importância das professoras primárias precisarem seguir tantas orientações em relação à sua conduta, tanto no tocante à sua vida particular quanto na sua vida pública - e muitas vezes parecia não haver distinção entre uma e outra - justifica-se em grande parte dos textos pela necessidade delas representarem um exemplo para os alunos. O professor universitário Abgar Renault ${ }^{102}$, em artigo publicado na RBEP em 1955, acerca da "missão" das professoras que trabalhavam na zona rural do país, dizia que a escola estava em um processo de "civilização" e daí a importância de ter a figura da docente como exemplo: "a comunidade não é diferente da dos vossos alunos, que são, via de regra, um espelho que repete facilmente as atitudes e os atos da escola, isto é, da professora. Mais da metade do processo educacional é um jogo de espelhos e reflexos". (p. 242 - grifos meus) Devido à plasticidade da infância, fase da vida na qual os indivíduos seriam mais facilmente moldáveis no tocante à sua personalidade e à sua conformação moral, a situação pedagógica e a relação entre os professores e os alunos poderiam ser identificadas pela metáfora dos espelhos e dos reflexos. Se as regras morais funcionam para orientar o comportamento e as atitudes daqueles que ainda não sabem decidir, na sala de aula, a

\footnotetext{
101 "Encontro de Educadores do Vale do Paraíba", comemoração do centenário da cidade. RBEP, nº 65, jan./mar. 1957, p. $186-196$.

102 RENAULT, Abgar. (publicado inicialmente no "Mensageiro Rural", Minas Gerais) "A professora rural e o cumprimento de sua missão", o texto é um discurso que foi proferido pelo paraninfo da $2^{\text {a }}$ turma da Escola Normal Rural “A. S. Azevedo”, de Minas Gerais, RBEP, n 60, out./dez. 1955, p. 235 - 243.
} 
conduta das professoras deveria refletir, para os alunos, a maneira correta de agir, de falar e de ser, transformando as crianças no espelho daquelas que lhes ensinavam.

Jean Piaget (1994), ao estudar o lado racional da moral, considera que o universo moral de cada pessoa é composto de hábitos e tradições impostos pelas gerações anteriores. Acerca da natureza psicológica da criança e das condições e dos meios psicológicos nos quais se realiza a formação moral, o autor afirmou que, até os sete anos, o comportamento moral da criança diz respeito à ordem. Até essa idade o "bem" geralmente é a obediência, e o "mal" é a desobediência. Nesta idade ainda não há consciência de sua conduta moral. A partir da idade escolar, considerada pelo autor como "idade da razão", e até o fim da escolaridade primária, a criança aprende progressivamente sobre as verdadeiras noções morais. A constituição da consciência moral marca uma etapa decisiva para a intervenção do educador. Essa aparição tem lugar no momento no qual a criança deve ser capaz, de certa maneira, a resistir aos seus impulsos e aos seus instintos, no momento no qual ela começa a distinguir o bem do mal. É desejável que lhe ajude a mobilizar as suas disposições e os seus recursos a fim de que possa orientar sua vontade para um e não para outro fim. A inteligência e a reflexão conduzem à definição das noções de justiça e de igualdade. Na idade na qual as crianças estivessem cursando o ensino primário, que compreende dos 7 aos 10 anos, o desenvolvimento moral estaria ligado à evolução afetiva. Segundo Piaget, um dos sentimentos que aparece ao mesmo tempo em que a consciência de si é a honra, que pode se manifestar sob a forma de coragem ou de vergonha. Sob a influência do meio escolar, a afetividade se enriqueceria e faria com que fossem desenvolvidos sentimentos altruístas, como a piedade, a solidariedade e a cooperação, promovendo a manutenção de uma ordem social fundada sobre o respeito mútuo dos direitos e dos deveres de cada um. A partir dos 10 anos o aluno adquire as noções do bem e do dever, graças à reflexão, ao julgamento e ao desenvolvimento de sua consciência moral.

Segundo Sólon Borges dos Reis ${ }^{103}$, diretor do CPP, a adolescência seria uma fase crítica porque os jovens passariam a questionar e desconfiar da "palavra indiscutida do professor" na escola primária. Nesse instante da vida eles passam a limpo sua escala de valores e seriam indóceis. Desta forma, para educá-los "não bastam festividades esporádicas, nem preleções formais em ocasiões comemorativas, se o conteúdo delas não

${ }^{103}$ REIS, Sólon Borges dos. (Inicialmente publicado no Correio Paulistano, São Paulo). "Educação moral e cívica na escola secundária”, RBEP, n 57, jan./mar. 1955, p. 176 - 178. 
corresponder efetivamente à atuação pessoal dos mestres, elas não terão sentido no conceito dos jovens. (...) À medida que a convivência avança, vai se configurando na alma do estudante o perfil definido do professor que ele tem". (p. 177 - grifos meus) Para ele, na escola, o professor "bonzinho" não seria bom, seria ridicularizado pelos alunos, sendo preciso dizer não e suportando o incômodo disso: "sejamos o exemplo e estaremos educando. Moral e civismo só se entende em termos de conduta”. (p. 178) O professor universitário Imideo Giuseppe Nérici ${ }^{104}$ também demonstrava preocupação com a necessidade de formar moralmente os adolescentes. Em artigo publicado na RBEP sobre a formação dos professores secundários, ele dizia que "a época em que todas as convenções morais, religiosas e sociais caem por terra desorientam o adolescente. Este precisa construir, com a ajuda do professor, um conjunto de valores para poder agir nesse mundo. É decisivo o papel do professor." (p. 219) Para Nérici, haveria vários "tipos" de professores: "vaidoso e pernóstico, não serve de modelo para os adolescentes; tímido e desconfiado, não tem coragem de enfrentar o olhar do aluno; colérico, que faz ameaças; lamuriento, relata seus problemas na classe; cético, não acredita na educação; sarcástico, se julga um sábio; infantil e crédulo, os alunos fazem o que querem e vivem em constante vadiagem mental; instável, inseguro; injusto e vingativo, vive dizendo que ninguém vai passar de ano; confuso, sem planejamento; tagarela; rotineiro; despótico, procura dominar os alunos; econômico, executor do programa; sádico; masoquista, quanto mais se instala a anarquia na classe mais satisfeito; distante." (p. 219) No entanto, o "bom professor" seria aquele dotado de "compreensão, amor e justiça" e que fosse capaz de estabelecer relações harmoniosas com os alunos. Anunciado como uma entidade, o "bom professor" deveria encarnar todas as virtudes, de modo a servir de exemplo e a educar corretamente as crianças. O professor Romualdo Monteiro de Barros ${ }^{105}$, em artigo publicado na RBEP em 1953, no qual tratava das qualidades que deveriam ter os professores, dizia o seguinte: "há várias espécies de professor: o que nasceu professor, o que fez formação especial e não é autodidata: 'Ide e ensinai', lhe diz a Escola, como Cristo disse a seus apóstolos: Euntes, docete. O professor para os ofícios no Templo da Ciência e o sacerdote no Templo da Fé." (p. 167) Nessa tipologia apresentada pelo autor, também haveria o "professor de vocação

\footnotetext{
${ }^{104}$ NÉRICI, Imideo Giuseppe. (Correio da Manhã, Rio) "Formação do professor secundário", RBEP, n 65 , jan./mar. 1957, p. $216-222$.

${ }^{105}$ BARROS, Romualdo Monteiro de. (Folha de Minas, Belo Horizonte) "Qualidades do professor", RBEP, no 50, abr./jun. 1953, p. $166-169$.
} 
tardia, o que é professor nas horas vagas e o curioso". Contudo, a condição primordial para o exercício do magistério, segundo Barros, seria "a 'Cultura', condição essencial. Depois vem o 'Método' e depois a 'Disciplina', que é respeito, cordialidade, atitude. Também é preciso 'Dedicação', afeição e amor à juventude. Também é preciso 'Entusiasmo' e 'Justiça'. 'Inspiração religiosa', para um sacerdócio que é fraternidade, renúncia e sacrifício. Falamos aqui de religião no sentido que lhe deu Salomon Reinach: derivado de 'religere' que é o contrário de 'neglegere' e significa: cuidado espiritual e meditação." (p. 168 - grifos meus) Além disso, os professores também deveriam possuir vocação, que seria uma síntese, segundo o autor, de: paciência, sinceridade, coragem, boa dicção e assiduidade. Apesar de muitas referências terem sido feitas à formação, muitas vezes, pelo discurso enunciado acerca dos professores primários, parece que as características desejáveis a esta profissão teriam algo de inato. Para Rodrigues Alves ${ }^{106}$, professor de escola normal, em artigo publicado na RP em 1959, o bom mestre seria aquele que "nasceu para ensinar, ensina por vocação" e trabalharia para alcançar, nos alunos, os fundamentos de uma verdadeira linha de conduta. Segundo Alves, "o caráter é imutável, mas é educável. A educabilidade não depende da reforma do caráter psicológico, mas sim da formação do caráter moral. Qualidades do verdadeiro professor, segundo opinião de alunos: é paciente, mantém a disciplina, não grita, nem perde o autodomínio, tem personalidade atraente, ajuda a resolver os problemas pessoais dos alunos, jovial, bondoso, veste-se bem, castiga com benignidade. $\mathrm{O}$ ideal é que essas qualidades sejam congênitas, que o professor as traga do berço, para ele se sentir mais à vontade no sagrado, e também espinhoso, exercício da Cátedra." (p. 25 - grifos meus)

Acreditava-se que a vida dos professores fora da escola, assim como as suas opiniões, exercia influência sobre as crianças e os jovens. De acordo com o relatório ${ }^{107}$ apresentado na Conferência das Escolas para a Compreensão Internacional, em colaboração com a UNESCO, em 1955, seria “indispensável que aqueles que se ocupem de educação possuam idéias positivas e não sejam tão somente membros neutros dentro da comunidade. (...) o melhor modo de guiar homens é apresentar-lhes uma clara visão do homem que executa o seu ideal na prática. $\mathrm{O}$ professor deve ser uma pessoa mentalmente

\footnotetext{
${ }^{106}$ ALVES, F. Rodrigues. "Qualidades positivas do bom mestre", RP, jan./1959, p. 25.

107 “A formação de professores" Trata-se do relatório apresentado na Conferência das Escolas para a Compreensão Internacional, em colaboração com a UNESCO, em 1955. RBEP, nº 64, out./dez. 1956, p. 141 -179 .
} 
sã" (p. 155). O documento chamava a atenção também para a importância da higiene mental dos professores, que seria responsável por lhes proporcionar uma continua adaptação ao meio no qual estivessem inseridos. Em 1979, Ethel Bauzer Medeiros ${ }^{108}$, pesquisadora da Fundação Getúlio Vargas, publicou um artigo na RBEP no qual tratava da importância das brincadeiras para o desenvolvimento infantil. Para ela, "as brincadeiras propiciam ainda a socialização, pelo exercício de vários papéis sociais (com as suas normas de conduta) e pela formação de lealdades sociais (com os seus aspectos morais). Ajudam a descoberta do eu e do outro, contribuindo para a construção da identidade pessoal. Beneficia-se também a cultura, pois modelos de comportamento, conhecimentos, crenças e valores são mais facilmente transmitidos de uma geração à outra. Imitando desde os primeiros anos os modelos de conduta que os adultos lhes apresentam, as crianças se inclinam ao sedentarismo e à passividade diante da vida. (...) Despreparados, como é natural na idade, não tem liberdade de escolha. Os adultos lhes servem de exemplo, intencionalmente ou não.” (p. 267)

Contudo, outro elemento importante que deve ser considerado acerca do controle exercido sobre o comportamento das docentes é o fato de, que, no Brasil, até a década de 1960, por exemplo, apenas pouco mais da metade das professoras que atuavam nas escolas primárias tinham formação profissional. Desta forma, se as escolas normais poderiam ser consideradas instituições que formariam as professoras que acordo com as normas adequadas ao exercício da profissão, formando, especialmente, o tipo de professora considerado ideal para formar o cidadão, que deveria ser trabalhador, ordeiro, disciplinado e que pudesse contribuir para o progresso social, o que esperar de pessoas que lecionavam, mas não haviam passado por tal processo de formação? Segundo Leonor Maria Tanuri (2000), o Censo Escolar “iria revelar que dos 289.865 professores primários em regência de classe em 1964, apenas 161.996, ou seja, 56\%, tinham realizado curso de formação profissional. Dos $44 \%$ de professores leigos, 71,60\% tinham apenas curso primário (completo ou incompleto), 13,7\%, ginasial (completo ou incompleto); 14,6\%, curso colegial (completo ou incompleto).” (op. cit., p. 77) A própria organização institucional dependia da regularidade, pontualidade e fidelidade, ou devoção, dos seus professores. Em

\footnotetext{
${ }^{108}$ MEDEIROS, Ethel Bauzer. "Brincar: uma das ocupações mais sérias da infância", RBEP, nº 143, jan./abr. 1979, p. $259-268$.
} 
artigo publicado na RP em 1962, Rodolpho Pereira Lima ${ }^{109}$, educador do ensino primário, criticava o controle, segundo ele, excessivo, exercido pelos superiores hierárquicos ao trabalho dos professores: "deve-se libertar a docência do magistério primário das diretrizes rijas dos comunicados. Estas devem ser apresentadas como sugestão, nunca como uniformidade e imposição" (p. 17). Além disso, aqueles que não se apresentassem como exemplo teriam dificuldades ao realizar cobranças com relação ao comportamento dos alunos. Alguns autores consideravam que a influência que os professores exerciam sobre o comportamento das crianças era ainda maior do que aquela que a família poderia exercer. A professora Cinéa Vieira Ramos ${ }^{110}$ era uma das autoras que partilhava desta opinião. Em artigo publicado na RP em 1959, ela dizia que "a criança é em geral dócil e sempre pronta a agir, para o bem ou para o mal, de acordo com a situação e o estímulo que recebe. Seu professor lhe exerce grande influência, muitas vezes, superior à que lhe exercem os próprios pais. Ele é seu modelo. $\underline{\mathrm{O} \text { espelho que reflete em exemplos e emulações às suas }}$ atividades. Todas as atitudes do professor são observadas, todos os seus gestos, suas ações, enfim, todo o seu modo de ser, é visto, julgado e imitado. Daí a importância da sua formação moral e intelectual, com exemplos belos a serem imitados. Dessa orientação constante e metódica irá, furtivamente, incutindo no espírito infantil do educando, a noção exata do dever, pela formação de bons hábitos; hábitos de ordem, de obediência, de pontualidade, de economia, de honestidade, enfim, a verdadeira formação moral que se resume numa única palavra - disciplina.” (p. 10 - grifos meus)

Preocupados em controlar o trabalho dos professores, Mário Biagioni, professor primário, Osmar Martins Cruz, diretor de grupo escolar e José Marques Vállio ${ }^{111}$, inspetor escolar, publicaram um artigo na RP, em 1959, no qual sugeriam que a contagem de pontos dos exames, que contavam para a ascensão na carreira, fosse substituída por um "boletim de merecimento", no qual fosse revelado o trabalho e o interesse do professor pelo ensino. Dentre os itens do boletim, estavam: "aspecto pessoal do professor - decência no traje e uso de avental durante o período de aulas, (...) espírito de cooperação, (...) interesse pelo trabalho educativo de caráter cívico e moral - considerar a atitude do

\footnotetext{
${ }^{109}$ LIMA, Rodolpho Pereira. "Quadro de aproveitamento nas escolas primárias", RP, Jan./Fev., 1962, p. 17.

${ }^{110}$ RAMOS, Cinéa Vieira. “A disciplina na escola”, RP, dez./1959, p. 9 - 10.

111 BIAGIONI, Mário; CRUZ, Osmar Martins; VÁLLIO, José Marques. "A escola primária e os exames finais", RP, mai./1959, p. $19-22$.
} 
professor e da classe por ocasião das festas cívicas e apresentação de trabalhos alusivos a datas como Dia das Mães, Dia das Árvores, efemérides nacionais, etc.” (p. 20) Entre os anos de 1960 e 1970, o conjunto dos referenciais de conduta dos professores se apresentava como uma exigência de regulação política que atendia a duas necessidades importantes: impor aos alunos um padrão de comportamento que eles deveriam seguir para que o sistema educacional conseguisse suportar a demanda que vinha recebendo e perpetuar entre os docentes atitudes de resignação e submissão às condições de trabalho cada vez mais desfavoráveis, simbólica e materialmente.

\subsection{O MAGISTÉRIO PRIMÁRIO: UMA PROFISSÃO DE FÉ}

No século XIX no Brasil, a educação moral era essencialmente religiosa. Sua eficácia advinha da espiritualidade da qual participaram todos os membros de um grupo determinado. A fé impregnava todos os atos da vida cotidiana: as prescrições da religião, os rituais e as práticas regulavam o comportamento individual e coletivo. Sob a ameaça das sanções divinas, que eram encarnadas pelas autoridades religiosas, a intransigência e a severidade dos padres inibiam a transgressão dos deveres e das regras, ou ao menos lhe colocavam uma barreira. A religião ordenava não apenas a educação, mas também todas as atividades dos homens, regulando a vida do nascimento à morte. $\mathrm{E}$ as crianças eram iniciadas nessa cultura desde muito cedo. Quando, ao final desde século, a República é proclamada, em 1889, os ideais positivistas, a divergência de opiniões e de crenças da época moderna perante um desacordo entre homens quanto à verdade absoluta, aliados ao progresso da ciência, situam as escolas, os grupos escolares, acima das religiões e das concepções filosóficas particulares. Os grupos escolares, concebidos pelo Estado para a sua manutenção, são então oficialmente separados da Igreja católica, devendo dispensar um ensino laico. A educação moral passaria então a ser empreendida independente de crenças e dos fins que a religião pudesse atribuir à conduta dos homens, mas deveria servir aos ideais republicanos visando à formação dos cidadãos úteis à pátria. Nas palavras de Diana Vidal e Luciano Faria Filho (2000), “apresentados como prática e representação que permitiam aos republicanos romper com o passado imperial, os grupos escolares 
projetavam para o futuro, projetavam um futuro, em que a República, o povo, reconciliado com a nação, plasmaria uma pátria ordeira e progressista” (op. cit., p. 25). A racionalidade almejada pelos republicanos, que deveria permear a educação pública, primaria por promover a civilização entre os homens. Nesta lógica, não haveria contradição pois, a moralização empreendida pela educação religiosa ficaria resignada a um espaço e a uma época determinados que, como o passar do tempo, seria substituída pela moralização laica, servindo ao projeto republicano que faria da educação um dos pilares da organização nacional. Não haveria contradição, não fosse pelo fato de o professor primário precisar vir a substituir o papel que antes cabia ao padre para tentar fazer de cada criança um homem educado, honesto, obediente e civilizado. Essa substituição, aliada ao fato da cultura brasileira ser fortemente impregnada de elementos religiosos, parece ter contribuído para que a representação dos professores enquanto agentes no processo de moralização dos indivíduos não mais estivesse dissociada de valores como sacerdócio, vocação, doação, sacrifício, etc. Seria como se, para conseguir que a educação moral fosse corporificada pelos alunos, fazendo parte de suas práticas, o professor primário, como antes fazia o pároco, devia não apenas ensinar e sugerir, mas ser ele próprio a moralidade encarnada. Curiosamente, para realizar uma educação que se pretendia laica, os docentes deveriam fazer uso de elementos religiosos, originários da religião católica, antes utilizados pelos padres. Os castigos físicos e a própria palmatória, que no início do século XX era símbolo do poder de coerção exercido aos alunos, evidenciam essa proposição. Mesmo sem fazer uso explícito dos dogmas religiosos, os professores deveriam trabalhar sobre os deveres que aproximam as pessoas. Seu dever seria conduzir cada um de seus alunos à prática consciente das obrigações da vida individual e social, ao desenvolvimento dos recursos de cada um e de sua personalidade, fazendo com que cada indivíduo adquirisse o autocontrole e o autogoverno necessários a orientar a sua vida.

Mas os valores sociais, cívicos, os fins positivos, aprovados e desejados por todos os homens honestos e conscienciosos, por todas as sociedades civilizadas, ideais dignos do esforço de todos, não faltariam ao ideal da educação laica. Contudo, a pretendida laicidade da educação escolar pública que, na prática, não existia mesmo após a promulgação da LDB no 4.024 de 1961, como foi possível depreender da análise realizada neste estudo, ao colocar a formação moral no centro de toda a ação educativa - para civilizar, doutrinar e moldar os indivíduos que deveriam servir à pátria - ativava os valores cristãos que haviam 
sido utilizados pelos padres para conformar moralmente os fiéis. Desta forma, o passado voltava ao presente mediante as práticas que, apesar de servir a um discurso que havia sido modificado ideologicamente, eram acionadas durante a educação escolar, sendo corporificadas nos indivíduos e evidenciadas pelas suas representações. Assim, o magistério exigia dos educadores que tivessem fé no seu trabalho, uma confiança profunda nas possibilidades de progresso e elevação da natureza humana, e exigia dos alunos que tivessem fé nos seus professores, naquilo que eles faziam, diziam e principalmente no que representavam: a encarnação da moral.

Diante da necessidade de receber professores, mesmo sem a marca da escola normal em sua formação, para suprir os espaços abertos para o ingresso na docência diante do aumento da demanda escolar, graças à expansão do ensino, era preciso cuidar da alma dos docentes e controlá-la. Originárias de classes sociais mais humildes e sem formação, ou com formação precária, o apelo à conduta docente diante de sua responsabilidade para com as crianças e o futuro da nação era grande. Em artigo publicado na RBEP em 1971, a propósito da validade da seleção psicológica de candidatos ao magistério, Paulo Rosas ${ }^{112}$, diretor do Instituto de Psicologia do Trabalho de Pernambuco, perguntava: "será que basta um curso rápido ou de reciclagem para um professorado mais eficiente?" Para ele, a educação seria por "demais importante" tanto em âmbito nacional quanto individual e, por esse motivo, a formação dos professores deveria ser muito cuidadosa, inclusive no tocante aos seus interesses e seus valores. Nesse caso, sem a formação desejável realizada nas escolas normais, as professoras deveriam então educar a si próprias. Como ocorreu com relação aos alunos, a expansão do ensino também levou as professoras a cuidarem de si próprias. A professora Botyra Camorim ${ }^{113}$, ao escrever sobre o "privilégio de ser professor", em artigo publicado na RP em 1963, diz o seguinte: “O privilégio de pertencer ao magistério é uma honra, se o professor souber ajudar seu semelhante a escalar os degraus do saber, baseado no amor. (...) A responsabilidade de um mestre, visando formar o caráter do aluno e transmitir os valores da cultura, obriga esses mestres a educarem-se a si próprios. O professor deve impor uma disciplina sadia, sem castigos." (p. 30 - grifos meus) Segundo ela, os professores trabalhariam para o bem comum que seria a grandeza

\footnotetext{
${ }^{112}$ ROSAS, Paulo. "Sobre a conveniência e a validade da seleção psicológica de candidatos ao magistério", RBEP, n 124 , out./dez. 1971, p. $306-315$.

${ }^{113}$ CAMORIM, Botyra. "Privilégio de ser professor”, RP, Jan./Mar., 1963, p. 30.
} 
da pátria: "nesses momentos de tanta incerteza que atravessa o país, nossas escolas são fontes de luz e amor. Liberdade de pensamento baseada na democracia. (...) Ao terminar, rogo a nosso Deus, que o professorado brasileiro saiba implantar no coração de seus alunos, os mesmos sentimentos e ideais daqueles que construíram esta pátria, mantendo viva a chama da liberdade, o mais precioso bem das criaturas e que jamais renunciem a esta luta valorosa e patriótica.” (p. 30) Evocando a consolidação do sentimento de Pátria e dos ideais democráticos, e, em muitos casos, "rogando a Deus", os discursos veiculados nos periódicos educacionais acabavam por evidenciar a necessidade social de obtenção de regras morais uniformes, que fossem válidas para todos, e que possibilitassem a normatização da conduta no espaço coletivo. A associação entre docência e sacralidade também está patente no artigo da professora primária Maria Dilcéa Belda Silva ${ }^{114}$, publicado na RP em 1963. Ela cita a Epístola de São Tiago, na Bíblia, e diz que é preciso ter fé e trabalhar: “Acreditais em Deus, não é fato? Nele e nos seus Evangelhos. Abri, pois a Bíblia, Epístola de São Tiago: 'Que aproveitará, irmãos meus, se alguém diz que tem fé, e não tem obras? Porventura poderá salvá-lo tal fé? Se um irmão ou uma irmã estiverem nus e precisarem do alimento quotidiano, e algum de vós lhes disser: Ide em paz, aqueceivos e saciai-vos, porém não lhe derdes as coisas necessárias ao corpo, de que lhes aproveitará?’ Assim também a fé, se não tiver obras, é morta em si mesma.” (p. 22) A autora acreditava que as pessoas deveriam ter aprendido o significado do patriotismo, "conhecido como amor ao próximo", na escola. Ele seria o "amor desinteressado". Acerca da "missão" docente, Silva afirma: "O ordenado que recebemos não compensa o sacrifício! Quando recebestes o diploma, sabíeis que essa profissão era missão, não trabalho comum. Quando pleiteastes a cadeira que hoje ocupais, tínheis conhecimento do que vos seria pago. Ninguém vos obrigou a aceitar o cargo com tal remuneração. Cumpre pois, executá-lo bem. Colegas, exceções existem e ai de nós, se assim não fosse, se o ideal viesse a sucumbir ante tantos obstáculos, tantas perseguições, tanta inveja, tantos deslizes. Sorte! Ele ainda flameja em muitos corações, o amor pela Criança, pela Pátria, pelo Ensino e acima de tudo por Deus! (...) A fé se mostra pelas obras. Pensaste nisto colega? Nas obras que deixastes de fazer, para Deus e para a Pátria? Acordai antes que o Senhor lhes venha perguntar: 'O que pudestes fazer e deixastes de fazer?" (p. 22) O professor primário e

${ }^{114}$ SILVA, Maria Dilcéa Belda. “Apelo”, RP, Jan./Mar., 1963, p. 21 - 22. 
diretor de grupo escolar Walter Schepis ${ }^{115}$, em artigo publicado na RP em 1959, também concebia o magistério como uma "profissão de fé". Para o autor, as professoras deveriam ter "moldura e lastro moral de uma personalidade inesquecível. Os estímulos são benfazejos de nossa vida, abençoados estímulos que somente a bondade de Deus nos poderia ofertar. O magistério é a mais nobre das profissões, profissão de fé, será o certo. Melhor não dizer profissão porque lembra logo remuneração. A sabedoria e o conhecimento proporcionam bem estar individual e coletivo. Aprimoramento moral. Felicidade individual e coletiva, dos povos e das nações. O artífice desta obra é a professora". O professor seria a "figura de proa da sociedade, modelo de virtudes e ações positivas, inigualável lidador da pena, da palavra e do labor diuturno da plasmação de personalidades. (...) Salve o professor, alavanca mestra da civilização, promessa, esperança e realidade de progresso material, moral e intelectual." (p. 4 - grifos meus) Quem também considerou que a remuneração deveria ser uma preocupação secundária para os professores, foi José de Lima ${ }^{116}$, ele próprio membro do magistério. Em artigo publicado na RP em 1962, ele dizia “o professor não deve viver contando os dias à espera do salário. “Ser professor, não é - quando lecionando no meio rural - descer física, moral e mentalmente, ao nível do mais rude tabaréu, alegando estupidamente, em defesa dessa condenável conduta, o provérbio: 'Viva em Roma, como romano...'; - mas sim, manter-se no seu Pedestal de Educador, sem afetação ou pedantismo. Vivendo assim, em 'Roma', como bom e exemplar estrangeiro". (p. 29) Não bastava que os professores fossem a própria moralidade encarnada, era preciso que eles dispensassem aos seus alunos um amor incondicional, como o amor de Cristo. Segundo Gilson Pereira (2001), a moral profissional dos professores, mesmo no início dos anos de 1980, ainda teria características do "espírito de doação", produto de aspectos carismáticos no magistério. Nas palavras do autor, ela "manifesta similitudes com a dádiva - um regime de atos desinteressados e nãoeconômicos - e tem parentesco com a moral familiar, sugerindo a proximidade da escola e da família como espaços de denegação do econômico” (op. cit., p. 117). Representada muitas vezes como um dom ou um "talento inato", não é por acaso que a remuneração pelo seu trabalho em grande parte dos artigos examinados fosse vista como algo dispensável ou secundário.

\footnotetext{
${ }^{115}$ SCHEPIS, Walter. "O inigualável plasmador da civilização”, RP, dez./1959, p. 4.

${ }^{116}$ LIMA, José de. “Ser professor...”, RP, Mar./Mai.,1962, p. 29.
} 
Em artigo publicado na RP em 1960, o professor Tulio Expedito Liporoni ${ }^{117}$ dizia: "Senhor! Tu que ensinaste, perdoa se eu ensino, se levo o nome de mestre que levaste pela terra. Concede-me o amor único de minha escola, que nem o sortilégio da beleza seja capaz de roubar-lhe minha ternura de todos os dias." (p. 30) Para o autor, os professores deveriam substituir a força pelo amor, e deveriam combater os maus hábitos das crianças. O meio no qual as crianças seriam criadas determinaria se elas seriam ou não desajustadas ou delinqüientes. Considerando que a casa e a família não contribuíam tanto para a formação moral dos filhos, caberia à escola formar o caráter e a personalidade das crianças, criando um ambiente propício para o desenvolvimento físico, mental e moral. Mas o autor perguntava: “está a escola preparando a criança para ser útil à si e à sociedade?” (p. 30) Ao lembrar-se das primeiras professoras que teve quando esteve no grupo escolar, o professor Ernesto Alves Filho ${ }^{118}$, disse que foi nessa época que compreendeu "a glória da igualdade". Dirigindo-se às professoras primárias, ele escreveu: "De vós e convosco surgiu a fé e a certeza no maravilhoso encanto da vida. O civismo é doutrinado por elas. Trabalham de charrete e até nos feriados. Instruem, educam, humanizam-se. O monumento não deve ser ao professor, e sim à professora primária.” (p. 4) Os pedagogos, e também professores, autores dos artigos publicados no periódicos, pareciam desejar transformar as professoras primárias, edificando-as de pessoas comuns a portadoras solenes da virtude. Com predicados que assemelhavam a vida das docentes à vida dos padres, as professoras também pareciam ter sido investidas de poder sagrado. Para o professor Daniel Marsh ${ }^{119}$, em artigo publicado na RBEP em 1953, acerca da "dignidade da profissão de ensinar", o professor "ocupa uma posição de influência. Em que altura elevada, pois, precisa ele viver! Se o professor é uma pessoa má, seu caráter é sentido em toda a escola. (...) Os jovens não podem compreender moralidades puramente teóricas; eles precisam de tê-las encarnadas, personificadas, demonstradas na vida diária. A sinceridade é uma grande virtude. O caráter de um professor é a sua eloqüência. Se ele age retamente, procede com bondade e anda humildemente junto a Deus; se suas palavras são castas e honestas, e a sua vida pura em seu propósito, toda vida será conseqüentemente mais pura e melhor. O professor cujo

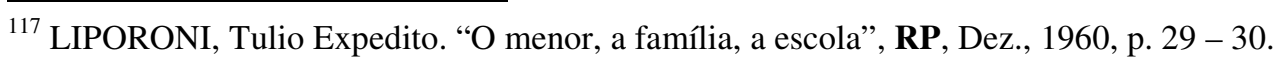

${ }^{118}$ ALVES FILHO, Ernesto. "Elas, as primeiras professoras", RP, dez./1959, p. 8.

${ }^{119}$ MARSH, Daniel L. (Revista do Professor - São Paulo) "Dignidade da profissão de ensinar", RBEP, $\mathrm{n}^{\circ}$ 49, jan./mar. 1953, p. $114-117$.
} 
ponto-de-vista é verdadeiro sempre se convencerá de que sua maior compensação é o depósito de caráter que ele faz no banco das vidas de seus discípulos.” (p. 117 - grifos meus)

Carlota Boto (1997), em estudo realizado sobre as escolas primárias portuguesas, escreveu a seguinte consideração a propósito das semelhanças entre os padres e os professores: "Com sua honradez e retidão equiparada à honradez e à retidão dos párocos, dos juízes, há aqui uma transferência de sacralidade. Portador do conhecimento, o professor é muito mais do que um erudito que guarda para si as verdades que descobre. $\mathrm{O}$ professor desenlaça o enigma e dá a chave do conhecimento, partilhando seu acesso com as populações com as quais interage. É portador, portanto, de um saber que traz, por definição, a vocação da partilha. Nessa medida, ao contrário de uma certa percepção cotidiana o professor estaria envolvido por uma aura de sacralidade, seja pela responsabilidade social de sua tarefa, seja porque, assim como o pároco, ele também se dedica à formação de corações e de almas infantis.” (op. cit., p. 514) Como se fossem investidos de poderes divinos, os professores deveriam se dedicar ao cuidado da alma das crianças. Ao tratar de tal tarefa que deveria ser desempenhada pelos docentes, considerada por muitos mais relevante do que ensinar a ler, a escrever e a contar, ou mesmo condição necessária para que estas últimas pudessem ser cumpridas, poucos autores fizeram referência às condições materiais de existência de tais profissionais como algo que devesse ser denunciado, mas Rodolpho Pereira Lima ${ }^{120}$ foi um deles. Em artigo publicado na RP em 1961, o professor primário reivindicava não apenas melhores salários, mas também pedia mudanças na legislação que regia a profissão, por considerá-la "arcaica": "os educadores famosos planejam novos sistemas pedagógicos, mas é o mestre desconhecido que dirige e guia a criança e o jovem. Ele vive na obscuridade e se contenta com pouco. É ele a sentinela, que, na obscuridade vigia contra a ignorância e o vício. Ele desperta os espíritos dormentes, encoraja os fracos e disciplina os instáveis. (...) O conhecimento se pode adquirir nos livros, mas o amor do conhecimento só se transmite pelo contato pessoal. Nenhum homem presta maior serviço à Pátria do que o mestre desconhecido." (p. 21) A representação dos professores veiculada tanto nos periódicos educacionais quanto nos manuais pedagógicos articulava os poderes civis e religiosos no intuito de moralizar.

\footnotetext{
${ }^{120}$ LIMA, Rodolpho Pereira. "Situação da docência no magistério primário", RP, Jul./Set., 1961, p. 21.
} 
Através das fontes consultadas, os docentes eram vistos como pessoas capazes de moldar o caráter das crianças para que elas viessem a ser, no futuro, os alicerces da sociedade e promovessem o desenvolvimento nacional. Das suas aulas dependeriam a formação moral e a formação intelectual dos brasileiros e os alunos seriam como “diamante bruto a ser lapidado", segundo Benedicto Rodrigues ${ }^{121}$, membro do magistério. Em artigo escrito na RP em 1961 como um discurso endereçado aos professores primários, o autor dizia: "Dos vossos exemplos de brasilidade, cultura e moral, dependem os quarenta pares de olhos a vos mirarem durante as quatro horas de aprendizado. Aos mestres: Neste momento sublime de vossa existência abraçastes a doutrina do Criador que arrastando suas vestes puras pelas estradas empoeiradas da Palestina, soube receber calúnias com o olhar sereno e mostrou-nos os mais elevados princípios de moral e instrução. $\underline{\text { A vós também }}$ compete procurar imitá-lo, sofrendo as dores íntimas para revelares alegria de viver, emoldurando de rosas as mágoas íntimas. (...) Vossas caminhadas serão jornadas de luz aos vossos sucessores. Vossos sacrifícios transformar-se-ão numa escalada de estrelas de cintilações prismáticas. Portanto, vossos atos são livro aberto aos que vos rodeiam. Cumpri fielmente vossa missão de mestre para serdes eternamente lembrado. De vós dependerá a soberania ou o cativeiro de vosso País, pois a responsabilidade do futuro do mesmo repousa nas crianças de hoje. Sois a pedra angular da sociedade que formará a Nação. Convém saberdes plasmar o caráter dessas criaturas que em vossas mãos foram confiadas. Abraçastes uma das mais sublimes carreiras: é espinhosa mas, cheia de glórias. Tudo dependerá apenas da vossa personalidade e sabedoria. (...) Deus vos inspire e o Divino Mestre vos encha de glória Professor Primário! Seja num grande núcleo social ou na escolinha de tábua do sítio, sois sempre o Mestre procurado. O 'Rabi' de quem tanto a Pátria espera e confia.” (p. 32 - grifos meus) A responsabilidade pelos sucessos ou pelos fracassos seria sempre dos professores e tudo dependeria deles. O que não era levado em conta, na maioria das vezes, era que os professores faziam parte de todo um sistema de ensino, e este era muitas vezes desconsiderado nos discursos veiculados, que transformavam a figura do professor de participante a protagonista de todo o processo educativo. Mais do que aquilo que ele sabia e poderia ensinar, o que seria decisivo para o sucesso na empreitada educativa seriam os seus atributos pessoais: a sua personalidade, o

\footnotetext{
${ }^{121}$ RODRIGUES, Benedicto. "Responsabilidade do professor”, RP, Jul./Set., 1961, p. 32.
} 
seu caráter e mesmo a sua capacidade de suportar a dor e o seu próprio fracasso. Encorajados a imitar Cristo, os professores deveriam sofrer as suas "dores íntimas" demonstrando alegria e emoldurando com "rosas" as suas mágoas.

\subsection{A SAÚDE E A APRESENTAÇÃO DAS PROFESSORAS PRIMÁRIAS: “SEJA UM EXEMPLO VIVO DAQUILO QUE EXIGE DOS SEUS ALUNOS"}

“Um homem pode ser-nos agradável por sua solicitude; pode, pelo diálogo, dar-nos o que pensar; pode incutir respeito pelo seu caráter; enfim, independentemente disso tudo e sem que tomemos em consideração alguma lei ou fim, ele pode aprazer-nos na mera contemplação e apenas por seu modo de aparecer. Nesta última qualidade, julgamo-lo esteticamente."

(Friedrich Schiller, A educação estética do homem, 1995, p. 107)

"Se você é uma jovem bem equilibrada, gozando de boa saúde, talvez se deixe tentar pela bela profissão que me esforço por descrever, sem esconder os espinhos sob as flores. Órgãos respiratórios e fonéticos em perfeito estado, sistema nervoso resistente, boa vista (com ou sem óculos), ouvidos capazes de perceber a origem e a direção dos murmúrios proibidos, nenhuma desgraça ou enfermidade física, alvo por demais tentador para as flechas dessa idade sem compaixão, constituem as condições necessárias para a abordar com probabilidade de sucesso. Mas, é preciso durante sua carreira cuidar do bom estado físico, manter a integridade daqueles órgãos, tão preciosos para o exercício da profissão; permanente controle de seus nervos, vida regular, sono reparador, exercícios físicos e passeios ao ar livre (sobretudo para as que habitam as cidades) mantê-la-ão jovem e ativa e a ajudarão a apreciar calmamente os fatos quotidianos, a dar a cada incidente sua importância real, sem a exagerar, a manter o agradável humor que a criança tem o direito de exigir quando você a receber à entrada da sala de aula" (GRAPPIN, A. "L'Institutrice" apud ROSAS, P., RBEP, 1967, p. 118). A citação anterior é transcrita do artigo de Paulo 
$\operatorname{Rosas}^{122}$, diretor do Instituto de Psicologia do Trabalho de Pernambuco, publicado na RBEP em 1967, no qual o autor escreve sobre o comportamento das candidatas ao magistério primário de Maceió. Se a exigência com relação à saúde das professoras primárias era grande, o mesmo não procedia quanto à dotação intelectual das mesmas. Elas deveriam ser ao menos "medianas quanto à inteligência", sendo "necessário relegar ao segundo plano este apetite de compreender e pôr em primeiro lugar a paciência, a simplicidade, a tenacidade". (p. 122) Afirmando que as mestras teriam grande responsabilidade no tocante ao equilíbrio e à felicidade das crianças, Rosas citou o pedagogo francês Alain (1868-1951), para quem o professor ideal teria: "aspecto físico agradável, criando uma corrente de simpatia desde os primeiros contatos mestre-alunos" (p. 122). O equilíbrio e a saúde mental das professoras para o comportamento dos alunos porque "professora inibidas e inseguras, ansiosas e agressivas são a própria origem da indisciplina, estimulando a insegurança, ansiedade e agressividade de seus alunos" e, ainda, "deficiências físicas são contra-indicações à prática do ensino primário (ex.: def. visual, auditiva, tendência a laringite, comportamento neurótico e/ou psicológico)" (p. 123). De acordo com o relatório ${ }^{123}$ apresentado na Conferência das Escolas para a Compreensão Internacional, em colaboração com a UNESCO, publicado na RBEP em 1956, "o professor tem boa saúde mental quando tem relações amistosas com seus colegas e alunos; ele se interessa por seu trabalho e pelas pessoas que o rodeiam, bem como pelos problemas pessoais e intelectuais que diariamente é obrigado a enfrentar." (p. 155) As relações entre a saúde mental e a função dos professores transparecem quando se pensa nos ideais que eles representam. Além disso, o "não reconhecimento da sociedade por seu trabalho, seu baixo prestígio por conta do baixo salário, defeito nas futuras gerações (por sua culpa), também podem influenciar desfavoravelmente a saúde mental do professor". Desta forma, o baixo prestígio aliado a grandes responsabilidades quanto ao futuro das novas gerações influenciavam a saúde mental dos professores. Em 1956, dizia o relatório ${ }^{124}$ apresentado na Conferência das Escolas para a Compreensão Internacional, em

\footnotetext{
${ }^{122}$ ROSAS, Paulo. "Exame psicológico de candidatas ao magistério primário de Maceió", RBEP, no 107, jul/set. 1967, p. $111-151$.

123 "A formação de professores" Trata-se do relatório apresentado na Conferência das Escolas para a Compreensão Internacional, em colaboração com a UNESCO, em 1955. RBEP, nº 64, out./dez. 1956, p. 141 -179 .

124 "A formação de professores" Trata-se do relatório apresentado na Conferência das Escolas para a Compreensão Internacional, em colaboração com a UNESCO, em 1955. RBEP, nº 64, out./dez. 1956, p. 141 -179 .
} 
colaboração com a UNESCO: "quanto ao estímulo da profissão, por mais que se trabalhe, não há possibilidade de ganhar mais, o que há é a possibilidade de diminuição do tempo de trabalho, passando a exercer outras funções, como a supervisão ou a direção.” (p. 152) No caso do professor chegar a exercer outras funções no sistema de ensino, como a direção da escola, por exemplo, lhe caberiam outras atribuições, dentre as quais estava conduzir o trabalho docente. Em artigo acerca da direção no ensino primário, publicado na RP em 1960, Armando dos Santos $^{125}$, diretor de grupo escolar, dizia que a remuneração deveria ser condizente com o custo de vida e a representação social a que se obrigam os ocupantes do cargo. Os atributos pessoais desejáveis seriam: "acentuada personalidade e diplomacia nos atos funcionais, espírito diplomático, que seria conseqüência de educação moral e cívica, cultura geral especializada, agressividade equilibrada e equilíbrio emocional”. De acordo com o autor, "o bom diretor deve coordenar esforços quanto aos problemas docentes, às vezes reflexo da conduta pessoal do próprio professor. Como se infere, o sucesso, nesse cargo, não depende, somente, da preparação técnica do candidato. São-lhe necessárias qualidades inatas. E isto não existe lente que ensine. A escola não dá...” (p. 26) Assim como no caso de alguns discursos dirigidos aos professores, a noção de inato também revestiria o cargo do diretor escolar.

A aparência das professoras também era importante para o exercício da profissão. Afro do Amaral Fontoura, no livro Metodologia do Ensino Primário, que em 1955 estava na sua $6^{a}$ edição, ao tratar dos atributos físicos dos professores apresentava uma ficha de avaliação na qual defendia que as suas qualidades físicas deveriam ser: saúde, audição, olhar, voz, porte e vestuário. Este último item seria: um "vestuário correto, sem modas exageradas (vestidos escandalosos, pintura excessiva), sem muitas pulseiras e jóias" (op. cit.,p. 39). O professor universitário Abgar Renault ${ }^{126}$, em discurso que proferiu na ocasião em que foi paraninfo em uma formatura de uma escola normal rural, encorajava as formandas a "lançar um novo estilo de vida no campo". Ele citou um inquérito realizado nos EUA acerca das qualidades das professoras: em décimo lugar estaria o conhecimento das disciplinas. "Antes", dizia Renault, "vinham a aparência, a capacidade de despertar interesse, a paciência, a cordialidade, a vista, a audição, a dicção, a vida ilibada, a

\footnotetext{
${ }^{125}$ SANTOS, Armando dos. "O problema da direção no ensino primário”, RP, Dez., 1960, p. 25 - 26.

${ }^{126}$ RENAULT, Abgar. (publicado inicialmente no "Mensageiro Rural", Minas Gerais) "A professora rural e o cumprimento de sua missão", o texto é um discurso que foi proferido pelo paraninfo da $2^{a}$ turma da Escola Normal Rural A. S. Azevedo, de MG. RBEP, nº 60, out./dez. 1955, p. 235 - 243.
} 
ascendência moral e a justiça." (p. 236 - grifos meus) Luiz Alves de Mattos, no Sumário de didática geral, que em 1967 estava na sua $7^{\mathrm{a}}$ edição, dizia que o "professor deve ter normalidade física e boa apresentação; perfeito controle emocional.” (p. 35), considerando como principais fatores de motivação da aprendizagem: "a personalidade do professor, o porte, a aparência física" (p. 210). No livro Didática do ensino primário, reeditado pela $7^{\mathrm{a}}$ vez em 1960, Brisolva B. Queirós, também considerava elementos pessoais, relacionados à apresentação física dos professores, como fatores importantes para o exercício do trabalho docente, entre eles estariam "a aparência, as maneiras, a voz". (p. 17) Afro do Amaral Fontoura, no manual pedagógico intitulado Didática Geral, reeditado pela $8^{\mathrm{a}}$ vez em 1965 , sugeria, normalmente usando o genérico masculino "o professor", que seus atributos fundamentais deveriam ser "suas qualidades físicas e morais" (p. 9) O "porte do professor" deveria ser "simples, sem enfeites excessivos" (p. 24), contando com "apresentação e vestuário correto", "sem vestidos e pintura excessiva" (p. 29). Mesmo fazendo uso do genérico masculino "O professor", o problema com a apresentação estaria relacionado principalmente à condição de ser da professora. Defendendo que o professor fosse um "exemplo vivo daquilo que exige dos seus alunos" (p. 493), deveria ser ele próprio disciplinado, para que conseguisse bem formar e conduzir seus alunos. Através dos discursos dirigidos à postura e à apresentação dos professores, é possível depreender que o comportamento desejável aos professores seria semelhante àquele desejável aos alunos: no exercício do magistério primário, o ato de educar as crianças seria como fazer do outro a extensão de si próprio. Os professores também "deveriam ter atributos físicos, intelectuais e morais" (p. 23), "deve ser bondoso, honesto, correto. Apresentar uma conduta moral irrepreensível, já que os alunos o tomam como exemplo e a sociedade acompanha atentamente a sua vida" (p. 25) além de se comportar bem em qualquer lugar que esteja, porque, para exigir disciplina dos alunos, eles próprios deveriam ser disciplinados. Fontoura aborda a questão do vestuário enquanto um dos atributos fundamentais das professoras, devendo ser ele: um "vestuário correto, sem modas exageradas (vestidos escandalosos, pintura excessiva), sem muitas pulseiras e jóias" e recomenda: "a professora não deve ir para a aula nem vestida de 'andar em casa', nem como se fosse para uma festa." (p. 29) A imagem dos professores, principalmente das professoras primárias, representadas veiculadas nas fontes consultadas evidenciam tem como marcas a modéstia, a discrição e transparecem inclusive uma certa abnegação da própria vida pessoal. Paula Vicentini (2009), ao realizar um estudo acerca das fotografias de professores veiculadas na 
grande imprensa por ocasião das comemorações do Dia do Professor, afirma que a insígnia "digno e modesto" estava presente nas imagens analisadas. Ao referir-se a uma fotografia que retrata uma professora homenageada pelo jornal Última Hora, publicado no Rio de Janeiro, em 1954, a autora faz a seguinte análise: "De cabelos grisalhos e curtos, sem brincos, corrente ou qualquer enfeite na parte da roupa vista na fotografia (...) ao explicitar os aspectos que caracterizaram sua carreira como exemplar, o jornal difundia os valores predominantemente cultuados pelo magistério primário - a dedicação, o sacrifício, a valorização da recompensa simbólica decorrente do futuro dos seus alunos e o amor ao trabalho mesmo após 48 anos de profissão - e a aparência que deveria caracterizar as mestras: basicamente, a simplicidade e a austeridade. (op. cit., p. 175 - 176) Inculcada pelos indivíduos e acionando práticas, a moral também é revelada mediante os usos do corpo, através de sua apresentação e das roupas que, no caso das professoras primárias, representavam a humildade, a decência e o recato.

\subsection{A "MATERNIDADE ESCOLAR": AS PROFESSORAS COMO MÃES}

Luiz Pereira (1969) dizia que o magistério primário, nos anos de 1960, cumpria funções "paradomésticas". Se, por um lado, a profissão poderia ser concebida como ocupação secundária de algumas mulheres, que poderiam dedicar-se ao lar, à família e aos filhos, e trabalhar em meio período, por outro, a característica "maternal" das professoras parecia ser exigida no cumprimento da docência ${ }^{127}$. O relatório ${ }^{128}$ apresentado na Conferência das Escolas para a Compreensão Internacional, em colaboração com a UNESCO, sobre formação de professores, dizia que, de fato, supunha-se que os professores que tivessem experiência com crianças fora da escola seriam mais capazes de guiar o crescimento emotivo e intelectual de seus alunos. O que poderia ser justificado, porque "as experiências advindas da paternidade ou da maternidade, da parte de pais

\footnotetext{
${ }^{127}$ Acerca das atividades de cuidado na prática docente no ensino primário, ver o trabalho de Marília Pinto de Carvalho No coração da sala de aula: Gênero e trabalho docente nas séries iniciais São Paulo: Xamã, 1999.

128 "A formação de professores". Trata-se do relatório apresentado na Conferência das Escolas para a Compreensão Internacional, em colaboração com a UNESCO, em 1955. RBEP, nº 64, out./dez. 1956, p. 141 -179 .
} 
cordatos podem favorecer a mais rica base possível. Por isso é condenável a prática usada em alguns países, que leva as moças a abandonarem o magistério quando contraem núpcias, como também a má-vontade em admitir mulheres casadas como professoras. (...) Não há dúvida, porém, de que as professoras que se casam e se afastam por algum tempo para constituir família, voltam, depois, com muito mais possibilidades de oferecer uma contribuição especial à educação. A profunda experiência conseguida com seus próprios filhos lhes permitiria suprir uma prática de longos anos adquirida por suas colegas que permaneceram solteiras." (p. 151) Além disso, dizia o relatório, uma das recompensas que o magistério poderia trazer aos professores seria o afeto dos alunos. As crianças poderiam projetar nos professores a reação que teriam com os pais. Até mesmo os adolescentes seriam profundamente influenciados pelas opiniões dos professores: "de qualquer modo, pode o adolescente receber mais de seus professores que de seus pais e isso simplesmente porque aqueles não tiveram influencia sobre as situações emotivas e relações de sua infância. Por isso é essencial que a saúde mental dos professores seja ótima." (p. 156) Segundo Robert J. Havighurst ${ }^{129}$, pesquisador do INEP, em artigo publicado na RBEP em 1957 sobre as tarefas evolutivas das crianças e dos adolescentes, o crescimento, além do aspecto físico, também consiste nos modos de proceder. As atividades de caráter social são fruto da aprendizagem proporcionada pela sociedade, daí a importância dos exemplos. E, naquele momento, as professoras primárias corresponderiam à nova figura materna ou paterna. A autoridade materna, emprestada às professoras, seria vista como fonte de conhecimentos e da verdade.

Diferente de outros países, como a França, por exemplo, no Brasil, quase todo o ensino primário era exercido por mulheres. Segundo Aparecida de Joly Gouveia $(1965)^{130}$, pesquisadora do CRPE de São Paulo, a presença dos homens se limitava a 7\% do número total dos docentes no magistério primário. Para Paulo Rosas ${ }^{131}$, em artigo publicado na RBEP em 1967, apesar da resistência em se admitir o trabalho da mulher fora do lar, o magistério configurava uma exceção: "atitude que se explica psicologicamente pela escola simbolizar o grupo familiar, onde a mestra representaria o papel de mãe”. (p. 126)

\footnotetext{
${ }^{129}$ HAVIGHURST, Robert J. "Tarefas evolutivas das crianças e dos adolescentes", RBEP, $n^{\circ}$ 67, jul./set. 1957, p. $130-143$.

${ }^{130}$ ROSAS, Paulo. "Exame psicológico de candidatas ao magistério primário de Maceió", RBEP, no 107 , jul/set. 1967, p. $111-151$.

${ }^{131}$ Idem.
} 
Representando o papel de mãe, a professora deveria desempenhá-lo com amor. Afro do Amaral Fontoura, no manual pedagógico intitulado Didática Geral, na reedição de 1965, dizia que sem amor não há educação. O "amor" enunciado nos textos parece que viria a suprir carências, inclusive afetivas, que as crianças que ingressavam nas escolas carregavam. Para Heloísa Marinho ${ }^{132}$, professora do Instituto de Educação do Rio de Janeiro, "muito podem nos ensinar conhecimentos iluminados pelo amor. Nossas pobres crianças sofrem de fome do corpo e do espírito. $\mathrm{O}$ emprego de ginasianas mal pagas, sem formação profissional, deveria dar lugar ao magistério habilitado para a nobre missão de educar a infância.” (p. 71) Segundo Luiz Pereira (1969), a representação social da profissão estaria mais adequada às mulheres do que aos homens. Os argumentos de maior adequação do magistério primário ao sexo feminino seriam classificados em dois tipos. $\mathrm{O}$ primeiro diz respeito a traços da personalidade feminina, que atenderiam por "instinto maternal”, "carinho", “amor", "paciência”, "meiguice”, “compreensão", etc. O segundo corresponderia a fatores extrínsecos, que não estariam relacionados à personalidade da docente, mas sim às condições de funcionamento do magistério primário como profissão: baixos salários, poucas horas de trabalho diário e pouco prestígio social. Os argumentos apresentados delineiam o perfil das professoras primárias que, apesar da profissão lhes render má remuneração e pouco prestígio, não as impedia de transformar a escola numa extensão do lar. A propósito da questão, o autor cita José Querino Ribeiro, que dizia o seguinte: “(...) a função das mães, junto aos filhos, é quase idêntica à dos professores junto às crianças da escola elementar (...). E de fato: o currículo e os programas dos cursos normais coincidem exatamente com o que de melhor se poderia desejar para a formação da juventude feminina, independentemente dos interesses da dedicação à carreira do magistério. Nenhuma das atividades ou disciplinas escapa, de leve ao menos, aos interesses de qualquer mãe de família”. (op. cit., p. 70)

Carlos Corrêa Mascaro (1956), em análise acerca do ensino normal no Estado de São Paulo nos anos de 1950, na qual destacava a deterioração do processo de formação dos professores, sugere que, nas escolas normais, a pretexto de se inculcar nas normalistas o sentimento de amor às crianças, abriam-se créditos ilimitados às alunas, prejudicando a sua educação profissional. Nas escolas normais não havia reprovação e alunas que tivessem

${ }^{132}$ MARINHO, Heloísa. "Missão da educadora no jardim de infância”, RBEP, n 101, jan./mar. 1966, p. 63 72. 
nota zero em qualquer disciplina também eram aprovadas. Pelas funções "acessórias" que possuíam as instituições, como a transmissão de cultura geral e pela natureza propedêutica do curso, o ensino normal era o preferido pelas mulheres, contribuindo para a formação da mãe e da dona de casa. Mascaro dizia que, naquele momento, as escolas normais continuavam "a ser escolas para tudo, inclusive para a formação de professores primários" (op. cit., p. 39).

De acordo com Pereira, "essa analogia entre as representações acerca dos papéis docentes e dos papéis maternos reflete-se na concepção do magistério primário como espécie de extensão profissionalizada dos papéis maternos e na concepção da escola como prolongamento do lar - concepções essas que se verbalizam em encontradiças frases como 'a professora é uma segunda mãe', 'escola, continuação do lar'.” (op. cit., p. 51) Segundo o autor, tais argumentos apresentam-se como verbalização dos estereótipos ligados ao sexo. Os traços da personalidade feminina seriam mais adequados às sanções persuasivas, tidas como mais propícias ao desenvolvimento infantil. A "profissionalização" dos papéis maternos, representados pelas professoras primárias, contribuiria para a formação moral das crianças e seria de grande valia no período de expansão da escola. Para governar muitas crianças ao mesmo tempo, sem fazer uso de castigos físicos e de humilhações públicas, que eram severamente criticados, transpor para a escola o poder da autoridade materna consistiu em um dispositivo governo dos alunos e de controle de sua subjetividade. Pelo afeto e pelo encanto de que dispunham as moças que saíam das escolas normais sobre os alunos, o "amor às crianças" nos anos de 1960 talvez tivesse a função da palmatória de outrora. E as crianças, pelo amor à professora, como se fossem a sua segunda mãe, obedeceriam e agiriam de acordo com a vontade da mestra, para o "bem" delas.

Se o "amor materno" das professoras poderia contribuir para conformação moral dos alunos, o inverso também poderia proceder: se o seu trabalho não lhe trazia compensações materiais e independência financeira, o envolvimento afetivo pelos alunos poderia trazer às professoras uma espécie de recompensa simbólica pela sua atividade, auxiliando na sua própria moralização. Segundo Luiz Pereira (1969), havia mecanismos "psicossociais" e "econômicos" pelos quais o controle era exercido, no sentido de manter o sexo feminino em posições subordinadas ao masculino. O aspecto "passivo" da personalidade feminina colocaria as mulheres em situação desvantajosa diante do 
ajustamento ao mercado de trabalho bastante competitivo dos sistemas urbano-industriais e a má remuneração do magistério, mais adequada às mulheres que aos homens, contribuiria para fazer de seu salário apenas um suplemento à renda familiar, que seria constituída principalmente pela renda do trabalho masculino. Assim, a profissionalização feminina do magistério primário ainda não alcançava o estágio qualitativo da profissionalização masculina: “(...) estimulam a profissionalização feminina nessa área do mercado de trabalho mas, ao mesmo tempo, levam a profissionalização da mulher nessa ocupação até o estágio em que não rompa fortemente o tradicional equilíbrio hierárquico das categorias de sexo e o do sistema familiar com remanescentes patriarcais (...)" (op. cit., p. 61).

Segundo Eliane Teixeira Lopes (1991) sempre houve uma forte associação entre o trabalho docente, quando exercido pelas mulheres, e a maternidade. A primeira lei sobre instrução pública no Brasil, de 1827, já dizia que "as mulheres carecem tanto ou mais de instrução, porquanto são elas que dão a primeira educação aos seus filhos. São elas que fazem os homens bons e maus; são as origens das grandes desordens, como dos grandes bens; os homens moldam a sua conduta no sentimento delas" (apud LOPES, 1991, p. 26). Esta representação das mulheres enquanto pessoas mais aptas à realização do magistério do que os homens pelo fato de que no corpo delas são gestadas e nascem as crianças, presente em documentos relacionados à educação já no período imperial, permaneceu no discurso educacional através dos séculos. Em 1957, mais de cem anos depois, um informativo ${ }^{133}$ acerca dos Estados brasileiros, publicado na RBEP, sugeria que, em São Paulo, em caso de poucos recursos, se fosse necessário escolher entre educar as mulheres ou os homens de uma determinada região, era preferível educar as mulheres porque "educar um homem, é educar um indivíduo; educar uma mulher é educar uma geração” (p. 193).

Ao analisar redações de provas para o preenchimento de vagas no magistério de $2^{\circ}$ grau no Estado de Minas Gerais, realizado em 1980, Guido de Almeida (1986) identificou algumas das metáforas utilizadas pelos professores para descrever a sua profissão. Nestes textos, o amor apareceu como a "grande arma do educador", que o auxiliaria no desempenho de sua tarefa. O professor enxergaria a si próprio como um "manancial de amor". Para Almeida, "essa auto-imagem gratifica o professor; é seu salário emocional. O professor sente-se prestigiado, indispensável, promovido como ser humano, ainda que

133 “São Paulo” RBEP, nº 65, jan./mar. 1957, p. 186 - 196. 
inferiorizado como profissional, numa espécie de compensação" (op. cit., p. 78). Assim, a pedagogia do afeto exercida pelas professoras primárias poderia servir principalmente a dois propósitos: auxiliar as mestras a serem condescendentes com a nova clientela, que não trazia o instrumental necessário para decifrar a gramática escolar e não sabia comportar-se adequadamente na inserção neste espaço e consistir em uma recompensa simbólica graças a qual as professoras poderiam suportar as agruras e os sacrifícios exigidos pela profissão.

\subsection{0 “BOM PROFESSOR”}

Como uma espécie de entidade, o "bom professor" aparece veiculado nas fontes examinadas como se fosse um fetiche: seria como se todos desejassem formar e manter nas escolas o "bom professor" dotado de todas as qualidades almejadas para o exercício da função e de "poderes" que o fariam ensinar bem, resolver problemas, lidar com os pais das crianças, cuidar e amar seus alunos, independente das condições objetivas nas quais eram formados, viviam e trabalhavam os professores reais. Para Riva Bauzer ${ }^{134}$, em artigo publicado na RBEP em 1954, o "bom professor" seria aquele capaz de manter relações harmoniosas com os seus alunos, demonstrando sempre "simpatia e compreensão". Em contrapartida, haveria "o professor que quer dominar a classe a qualquer custo, gerando tensão emocional, medo e submissão. Quando, porém, apesar de seus esforços, não consegue dominar a classe passa a exibir comportamento de nervosismo, temor, desespero que projeta sobre sua turma, contribuindo para o aparecimento de frustrações, inquietações, desatenção, vadiagem, atitudes acintosas de desrespeito etc., que exigem constantes soluções de cunho disciplinar rígidas e inflexíveis". (p. 222) As atitudes dos professores, derivadas de seu equilíbrio emocional, inteligência, hábitos, habilidades, traços de personalidade, saúde, filosofia de vida, domínio de técnicas de ensino, seriam "a chave que permite prever o tipo de atuação que o professor vai ter na sala de aula”. Contudo, conclui a autora, "as atitudes que caracterizam o bom professor jamais poderão ser inculcadas em

\footnotetext{
${ }^{134}$ BAUZER, Riva. (Formação, Rio) "Personalidade do professor primário", RBEP, no 56, out./dez. 1954, p. $221-223$.
} 
professorandos pois o resultado dessa técnica não conduz ao estabelecimento de boas relações interpessoais entre professores e alunos." O "bom professor" seria aquele ajustado e que apresentasse bom rendimento profissional. Imideo Giuseppe Nérici ${ }^{135}$ concorda com Bauzer e cita a autora em artigo publicado na RBEP em 1957, afirmando que o "bom professor" seria aquele capaz de estabelecer relações harmoniosas com os alunos. A disciplina deveria ser um meio e não um fim: "para educar é preciso, fundamentalmente, compreensão, amor e justiça. (...) O bom professor tem como qualidades fundamentais: preparação técnica, adaptabilidade, amor ao próximo, estabilidade emotiva e espírito de justiça.” (p. 219) Ao tratar da formação docente, a autor criticava os cursos de didática por deixarem "muito a desejar e não conseguirem incutir nos professorandos nem a noção de causalidade, de determinação da conduta humana. No curso, o professorando aprende a ver a disciplina e não o aluno. Para a formação prática e a regência, o professorando deveria realizar relatórios sobre o comportamento dos alunos (forma de exercitar o estudante a observar o comportamento humano e notar as diferenças entre os alunos). Elaboração de fichas psicossociais de seus alunos." (p. 219) Para Daniel Marsh ${ }^{136}$, o "bom professor mantém a dignidade de sua profissão e estima a todos, de maneira individual." (p. 117) O professor Oswaldo Guérner Gonzalez ${ }^{137}$, em artigo publicado na RP em 1960, apresentou "três requisitos básicos para um indivíduo ser professor: conhecer bem as disciplinas que ensina, gostar dessas disciplinas, gostar dos alunos". Além disso, de acordo com o autor "sem entusiasmo e confiança, ninguém é um bom professor. Nenhum mestre deve querer lecionar como um disco de vitrola, onde estão gravados monólogos sem expressão e sem alma, como se fosse arandela destinada eternamente a receber espermacete." (p. 37 - grifos meus) Em 1962, na mesma revista, o professor José Garcia Ramos ${ }^{138}$ publicou um artigo intitulado "Atitudes de um professor diante de seus alunos". Nele, o autor apresenta alguns elementos que considera inerentes ao comportamento dos bons professores, tais como: "nunca usar a cadeira como descanso e não ficar muito tempo em um só lugar, dar explicações com o olhar vagando ou perdido no teto; chegar atrasado à aula; consultar

\footnotetext{
${ }^{135}$ NÉRICI, Imideo Giuseppe. (Correio da Manhã, Rio) "Formação do professor secundário", RBEP, n 65 , jan./mar. 1957, p. $216-222$.

${ }^{136}$ MARSH, Daniel L. (Revista do Professor - São Paulo) "Dignidade da profissão de ensinar", RBEP, $\mathrm{n}^{\circ}$ 49, jan./mar. 1953, p. $114-117$.

${ }^{137}$ GONZALEZ, Oswaldo Guérner. "Relações humanas", RP, ago./set. 1960, p. 37.

${ }^{138}$ RAMOS, José Garcia. “Atitudes de um professor diante de seus alunos”, RP, Jan./Fev., 1962, p. 7.
} 
freqüentemente fichas ou apontamentos durante a aula. (...) Linguagem: nunca falar muito baixo ou alto demais, não usar gírias. Não são os castigos que impõe a autoridade. Não criticar outros professores, é um mau exemplo para os alunos que estão em formação.” (p. 7) É possível perceber que uma representação do professor intuitivo é delineada pelos discursos veiculados nas fontes. O relatório ${ }^{139}$ apresentado na Conferência das Escolas para a Compreensão Internacional, em colaboração com a UNESCO, dizia que, para desempenhar eficazmente a sua tarefa, o professor deveria: “(...) desenvolver uma compreensão intuitiva de seus alunos; todos eles devem ser verdadeiramente capazes de sentir em conjunto seus alunos e de apresentar sua matéria de modo que corresponda plenamente às características e necessidades deles, quer se trate de física nuclear ou da tábua de Pitágoras. Se os docentes não fizerem um esforço consciente nesse sentido, a relação professor-aluno será negativa.” (p. 153) Contudo, o relatório prescreve que as “qualidades que caracterizam o 'ser humano normal' são indispensáveis desde a escola materna à Universidade, para tornar eficaz a tarefa do professor" (p. 153). Para Luiz Alves de Mattos, no Sumário de Didática Geral, reeditado em 1967, "a influência do bom professor se estende através de gerações”. (p. 82) Afro do Amaral Fontoura, no livro Didática Geral, reeditado em 1965, apresenta orientações acerca do comportamento do "bom professor" semelhantes àquelas que seriam necessárias ao "bom aluno". Ao demonstrar os atributos desejáveis ao docente, sugeriu o seguinte: "qualidades morais: deve ser bondoso, honesto, correto. Apresentar uma conduta moral irrepreensível, já que os alunos o tomam como exemplo e a sociedade acompanha atentamente a sua vida". (p. 25) Para ele, os professores deveriam ser formados com uma educação voltada para a "alma": ele deve "ser inteligente e educado" (p. 9), idealista e procurar trabalhar pelos outros: "para formar o caráter dos alunos, ele próprio precisa ter um grande caráter”. (p. 17)

139 "A formação de professores" Trata-se do relatório apresentado na Conferência das Escolas para a Compreensão Internacional, em colaboração com a UNESCO, em 1955. RBEP, nº 64, out./dez. 1956, p. 141 $-179$. 


\subsection{A VOCAÇÃO DAS PROFESSORAS PRIMÁRIAS}

"No magistério, mais do que em muitas outras profissões, é necessário desenvolver e conservar o sentido da vocação. E isso porque a matéria-prima com que trabalha o professor é, sobretudo, o espírito e a vida dos homens." ${ }^{\text {140 }}$ (p. 154) Devendo talhar o espírito dos alunos, os professores deveriam aplicar o mesmo feitiço a si próprios, resignando-se à ambigüidade de sua condição. Por amor a Deus e à pátria, os professores devotar-se ao seu trabalho e aos seus alunos. De acordo com o relatório ${ }^{141}$ apresentado na Conferência das Escolas para a Compreensão Internacional, em colaboração com a UNESCO, em 1955, era preciso evitar que portadores de "sinais graves de inadaptação" ingressassem no magistério. Cabia às pessoas que desejassem seguir a carreira docente que tivessem "senso de companheirismo". "A tarefa do curso de preparação do professor é melhorar o pessoal que ele é obrigado aceitar, por conta da escassez de professores em muitos países. Façam o possível para vencer a mediocridade. (p. 164)" O talento humanístico seria essencial para o prestígio e a eficiência profissionais, e a inteligência não estaria necessariamente ligada a isso: “(...) aos professores de crianças muito pequenas, não é essencial que possuam qualidades intelectuais elevadas, como se costuma pensar." (p. 165) De acordo com o documento, embora as "personalidades anormais" só costumem existir em pequena parte dos candidatos, sua presença na profissão é perigosa e é preciso descobrir e demitir essas pessoas logo, pois alguns elementos poderiam tornar-se nocivos com o decorrer do tempo.

O professor universitário e autor de manuais pedagógicos Luiz Alves de Mattos ${ }^{142}$, em artigo publicado na RBEP em 1958, dizia que "a missão do professor exige preparo esmerado e formação conscienciosa. $\mathrm{O}$ ensino exige do professor estabilidade, firmeza e dinamismo. Segundo o autor, "vocação e capacidade docente seriam dons inatos, nos meios populares. A vocação floresce no cerne da personalidade, significa propensão fundamental do espírito. O professor é naturalmente um estudioso e tem fé que a educação

140 "A formação de professores" Trata-se do relatório apresentado na Conferência das Escolas para a Compreensão Internacional, em colaboração com a UNESCO, em 1955. RBEP, nº 64, out./dez. 1956, p. 141 -179 .

141 Idem.

${ }^{142}$ MATTOS, Luiz Alves de. "A formação do moderno professor secundário" (inicialmente publicado em Escola Secundária, Rio) RBEP, nº 71, jul./set 1958, p. 145 - 153. 
leva ao bem viver e à felicidade. (...) Aptidões imprescindíveis: normalidade física e equilíbrio mental, asseio pessoal e boa apresentação, voz agradável, convincente, presença de espírito, desembaraço, liderança." (p. 146 - grifos meus) Em "Magistério e vocação",143, artigo publicado na RBEP em 1958, Heloísa Marinho defendia que os casos de indisciplina se multiplicavam quando as crianças sentiam a hesitação da mestra. A autora aconselhava aquelas que almejavam a carreira docente: "é preciso ter vocação para o magistério. A mulher amadurece em poucos anos. Aos 16 será muito diferente do que era aos 13. (...) Exige o magistério, além do conhecimento, amor à criança e espírito de sacrifício e dedicação, que não pode ser compreendido nos primeiros anos da adolescência. (...) Lembrem-se que o amor à criança, indispensável à profissão do magistério não pode ser medido nos exames de admissão, nem ensinado no curso normal. Só podermos desenvolver o que de início existe" (p. 138 - grifos meus). As crianças necessitavam do amor das professoras e estas precisavam dedicar-se à profissão: "não adianta ter um emprego vitalício se as obrigações são contra o temperamento da professora e o magistério, nobre missão, não é das profissões mais rendosas." (p. 138) Ofuscado pela idéia de vocação, que enobrecia a atividade profissional, o magistério primário parecia estar mais associado à conformação e à adaptação. Se, por um lado, as escolas normais falhavam no sentido de melhor formar os professores, e, segundo Mascaro (1956), "num país de parcos recursos financeiros e de precária economia mal formar o professor é concorrer para tornar insuportável para os orçamentos públicos e privados o alto preço da educação popular, tornando-se ainda mais remota a possibilidade do rompimento do círculo vicioso que se expressa pela dependência da cultura à economia e da economia à educação do povo". (op. cit., p. 16 - 17) Por outro, elas eram bem-sucedidas no sentido de continuar atraindo jovens. Pelo título polivalente que tinha o diploma de normalista, ele possibilitava tanto o exercício profissional, quanto a continuação dos estudos e a inscrição em concursos. Além disso, conformava-as para o desempenho do trabalho docente, mesmo se o preço a pagar pela tarefa fosse abrir mão de si próprias, transformando-se em um tipo de pessoa adequado ao exercício da profissão. O entusiasmo trazido pelos jovens no momento do ingresso no magistério primário, quando começariam a exercer o ofício, merecia atenção.

\footnotetext{
${ }^{143}$ MARINHO, Heloísa. (Correio da Manhã, Rio) "Magistério e vocação", RBEP, nº 70, abr./jun. 1958, p. $136-138$
} 
Segundo o relatório ${ }^{144}$ apresentado na Conferência das Escolas para a Compreensão Internacional, em colaboração com a UNESCO, em 1955, "o professor jovem merece respeito dos colegas, que devem auxiliá-lo e estar preparados para aceitar com tolerância qualquer manifestação excessiva de confiança em si próprio ou também incertezas. Ele não deve ser encaminhado às classes mais difíceis ou menos dotadas.” (p. 151) Talvez por conta do grande número de exigências pessoais que eram feitas às professoras, George $\mathrm{S}$. Counts $^{145}$, professor universitário americano, em artigo publicado na RBEP em 1953, dizia que as "professoras também são gente, buscam segurança, companheiro, filhos, bem-estar, felicidade.” (p. 53) Devido à quantidade de atribuições que cabiam aos professores, não por acaso, as "doenças da alma" eram comuns à categoria. Se nos anos de 1950 o magistério atraía as professoras por possibilitar a concomitância entre o exercício da profissão e a continuação dos estudos, nos anos de 1970 a carreira docente era procurada por mulheres mais pobres, que precisavam ingressar rapidamente no mercado de trabalho, diante da escassez de oferecimento de cursos profissionalizantes em nível médio e da impossibilidade de cursar o ensino superior (TANURI, 2000). Segundo Gilson Pereira (2001), o magistério é uma carreira marcada por ambigüidades: "nas referências ao gênero (professor, apesar de feminina)", nas “disposições humildes que antecipam práticas renunciadoras (na falta e impossibilidade de coisa melhor)", na "miséria de condição de uma funcionária colocada nos postos mais baixos das escalas funcionais (140 quilômetros diários para lecionar, 35 anos começando a pesar)" e no "etos missionário de uma profissão pertencente ao prestigioso universo da produção simbólica, mas de baixos retornos tanto materiais quanto simbólicos (servir a Deus, à pátria, ao próximo)” (op. cit., p. 18).

No exercício da docência, a vocação e o amor eram sublimados em relação à formação profissional e contribuíam para a constituição de um habitus que ressaltava a representação dos professores como "missionários" em detrimento dos trabalhadores assalariados da educação. A propósito da história na obra de Pierre Bourdieu, nas palavras

\footnotetext{
144 "A formação de professores" Trata-se do relatório apresentado na Conferência das Escolas para a Compreensão Internacional, em colaboração com a UNESCO, em 1955. RBEP, $\mathrm{n}^{\circ}$ 64, out./dez. 1956, p. 141 -179 .

${ }^{145}$ COUNTS, George S. "A educação dos Estados Unidos através do espelho soviético" RBEP, $\mathrm{n}^{\circ}$ 50, abr./jun. 1953, p. $44-53$.
} 
de Denice Catani (2008) "pode-se dizer que a história encarnada nos corpos equivale a um sistema de disposições duráveis, chamada por ele de habitus" (op. cit., p. 324). No caso da moralização no magistério primário, durante o período investigado, é possível perceber que a história incorporada pelos agentes, neste caso, traz consigo a gênese da profissão refletida na produção de suas práticas e representações, mesclando referências religiosas, evidenciadas pela figura do "professor sacerdote", e domésticas, evidenciadas pela figura da "professora mãe", por exemplo. No início dos anos de 1980, a propósito desta associação entre amor e trabalho docente, Guido de Almeida (1986) teceu a seguinte consideração: "interessa ao Estado que todos acreditem ser o amor suficiente para o exercício do magistério. (...) Nunca se poderá alegar má formação profissional, apenas falta de vocação. Se um profissional fracassa, é porque não nasceu para o magistério, pois o professor já nasce pronto. Se fracassa, é porque não ama os alunos como a seus próprios filhos. Nada mais útil e conveniente ao Estado do que divulgar, cada vez mais, esse tipo de pensamento: todos os defeitos da educação explicam-se por deficiências pessoais do professor. (...) Assim como a Escola costuma atribuir apenas ao aluno a responsabilidade pelo seu fracasso, o Estado quer atribuir apenas ao professor, pessoalmente, a ineficácia da educação." (op. cit., p. 80) Assim, os insucessos seriam meramente pessoais. Guido de Almeida chamava a atenção para o papel desempenhado pelo Estado na formação dos professores, e para este discurso, que os culpabilizava pela qualidade da educação, lhe ser útil ideologicamente. Em 1956, não era muito diferente a questão apontada por Carlos Mascaro acerca da qualidade da educação popular. Segundo o autor, era necessário reformar os cursos de formação de professores de modo a garantir uma efetiva qualificação profissional. Para garantir a legitimidade e a autenticidade do sistema de ensino, era necessário aprimorar a qualificação e a remuneração dos professores primários: "temos de convir que para que o magistério seja uma carreira capaz de atrair e despertar vocações seria necessária uma revisão geral nos conceitos relacionados com a sua profissionalização, com a sua posição na escala das atividades sociais, e com salários mínimos nesse campo." (op. cit., p. 39)

Assim, os caminhos nos quais percorrem a formação e o trabalho docente convergem num amálgama no qual se fundem e se transformam também na vida privada das mestras. O magistério primário, enquanto ofício no qual as mulheres eram preparadas para exercer uma atividade profissional com características domésticas e envolvida pelo 
afeto, transformava as moças em um determinado tipo de pessoa. Com o tempo de exercício da função, a representação (ou a encenação) realizada por essas pessoas fazia com que a profissão se tornasse parte de si próprias, ou melhor, constituísse a si próprias. Diferente de outras profissões, nas quais o resultado decorrente da atividade exercida é um produto, algo produzido por uma pessoa a outra, ou mesmo um serviço prestado a alguém, no caso do magistério primário, o fruto do trabalho corresponde à apresentação de si, que envolve o controle e o cuidado de si. Algo semelhante ao que ocorre com a profissão dos atores acontece com aquela exercida pelos docentes. Diferente dos pintores ou dos escultores, que têm na sua obra, um quadro ou uma escultura, um produto material que expressa todo o trabalho realizado, os atores são eles próprios a sua obra. No teatro, as artes cênicas só existem com a presença dos atores, com a sua exibição concreta e física: não há peça na sua ausência. Com os professores acontece algo semelhante: o desempenho do trabalho docente é indissociável da apresentação de si. Talvez por este motivo seja possível notar semelhanças entre o ofício de ensinar e a arte de representar: estilo, sedução e encanto são tão importantes aos atores quanto aos professores, ao menos nas formas prescritas pela literatura de formação do magistério. Também no caso das professoras primárias, elas seriam a sua própria obra.

Mediante o conceito de habitus é possível perceber como os comportamentos individuais vinculam-se às normas e estruturas sociais e como elas exercem esse poder sobre os indivíduos. Ele ajuda a compreender a lógica das práticas cotidianas (BOURDIEU, 2006). A origem do habitus dos docentes, que funciona como um princípio gerador de respostas que os agentes dão à realidade social, estaria no repertório de representações acumuladas desde a infância, época em que os membros do magistério primário freqüentavam a escola como alunos. Durante o ato de lecionar, as pessoas recorrem às essas representações para tornarem-se professoras e professores. As atitudes dos professores marcantes ao longo da vida escolar de alguém, por exemplo, podem ser incorporadas pela prática pedagógica ao serem mobilizadas por este indivíduo quando ele vier a lecionar. Desta forma o habitus docente caminha de geração em geração, através das representações e das práticas de seus agentes. A literatura pedagógica, ao prescrever as atitudes desejáveis à docência, traz evidências das representações acerca do trabalho docente no período que é escrita, mas também daquelas construídas pelos próprios autores desde a sua idade escolar. Com relação à prática docente, por mais que seja prescrito, 
planejado e orientado, o exercício do magistério é um habitus em exercício (CATANI, 2008; LUGLI, 2008). Philippe Perrenoud (1993), ao referir-se ao trabalho docente, sugere que as competências mobilizadas pelo professores durante sua prática parecem ter mais origem em automatismos do que na reflexão. Em situações de urgência, são mobilizados "fragmentos de representação e de conhecimento". Trata-se de esquemas de ação, de percepção e de decisão parcialmente "inconscientes". Segundo o autor, origina-se daí a impressão que muitos professores têm de que ensinam antes de tudo com "o que são" e com a sua personalidade. Com o conceito de habitus, "afastamo-nos da imagem da ação como construção racional e refletida; mas distanciamo-nos igualmente de uma concepção da ação como implementação de uma resposta pré-programada retirada de um repertório acabado. (...) o habitus pode-se construir não em circuito fechado, mas à medida de uma interação entre a experiência, a tomada de consciência, a discussão, o envolvimento em novas situações." (op. cit., p. 108 - 109) Através do estudo realizado, foi possível notar que essa impressão evidenciada por Perrenoud de que os professores têm que ensinar com "o que são" é partilhada por muitos daqueles que produziram a literatura pedagógica analisada, independente de sua posição no campo educacional: dos professores universitários e pesquisadores vinculados ao ministério da educação aos inspetores escolares e professores primários. Bourdieu (1990) define o conceito de campo como "um lugar de relação de forças (e lutas que visam à transformação ou à conservação), permanecendo o fato de que essas relações de força que se impõem a todos os agentes que entram no campo - e que pesam com especial brutalidade sobre os novatos - revestem-se de uma forma especial: de fato, elas têm por princípio uma espécie muito particular de capital, que é simultaneamente o instrumento e o alvo das lutas de concorrência no interior do campo" (op. cit., p.170). Essa representação que liga diretamente o trabalho docente ao modo de ser daquele que ensina é constantemente reafirmada no campo educacional através do tempo e contribui para fortalecer: a necessidade de moralização dos próprios professores primários, para que possam exercer bem a sua função enquanto agentes responsáveis por corporificar os valores morais nos seus alunos, fazendo com que a educação moral mobilize o comportamento dos mesmos e seja transformada em prática. E também, reproduzindo as características relacionadas ao sacrifício, ao sacerdócio e à abnegação da própria vida pessoal, essa imagem dos professores primários à qual as pessoas precisavam aderir para também tornarem-se docentes transmitia uma certa docilidade e muita resignação que ajudavam a perpetuar uma posição, desfavorável a eles 
próprios, no campo educacional. É dessa maneira que é possível compreender como a professora primária Maria Dilcéa Belda Silva ${ }^{146}$, em artigo publicado na RP em 1963, referia-se a seu próprio trabalho como uma missão e era enfática ao dizer aos colegas: “Quando recebestes o diploma, sabíeis que essa profissão era missão, não trabalho comum. Quando pleiteastes a cadeira que hoje ocupais, tínheis conhecimento do que vos seria pago. Ninguém vos obrigou a aceitar o cargo com tal remuneração. Cumpre pois, executá-lo bem. Colegas, exceções existem e ai de nós, se assim não fosse, se o ideal viesse a sucumbir ante tantos obstáculos, tantas perseguições, tanta inveja, tantos deslizes. Sorte! Ele ainda flameja em muitos corações, o amor pela Criança, pela Pátria, pelo Ensino e acima de tudo por Deus!" (p. 22). Assim também é possível entender como o professor primário Walter Schepis ${ }^{147}$, em artigo publicado na RP em 1959, concebia o magistério como uma "profissão de fé" e declarava: "o magistério é a mais nobre das profissões, profissão de fé, será o certo. Melhor não dizer profissão porque lembra logo remuneração. A sabedoria e o conhecimento proporcionam bem estar individual e coletivo. (...) O artífice desta obra é a professora" (p. 4 - grifos meus). E compreende-se ainda como o professor primário José de Lima ${ }^{148}$, em artigo publicado na RP em 1962, dizia que "o professor não deve viver contando os dias à espera do salário" (p. 29). Desta forma é possível compreender estes e tantos outros professores primários que, vivendo e trabalhando nas condições mais adversas e precárias, aceitavam o seu trabalho como uma missão, da qual eles não poderiam reclamar, já que ela era revestida de tanta nobreza e compensação simbólica que não lhes dava o direito a qualquer reivindicação, causando reprovação da imprensa e de diversos setores da sociedade quando eles começaram a se mobilizar e a organizar as primeiras greves da categoria, buscando melhores salários (LUGLI e VICENTINI, 2009).

Assim, por amor a Deus, à pátria e às crianças, os professores devotavam-se ao exercício do magistério e aos seus alunos, entendendo o seu trabalho como uma missão, abrindo mão dos próprios desejos e sacrificando a própria vida pessoal. Fruto de um processo de formação que impõe um habitus particular, associado à decência e à moralização, e muitas vezes ao longo da história da educação associado à abnegação da

\footnotetext{
${ }^{146}$ SILVA, Maria Dilcéa Belda. “Apelo”, RP, Jan./Mar., 1963, p. 21 - 22.

${ }^{147}$ SCHEPIS, Walter. "O inigualável plasmador da civilização”, RP, dez./1959, p. 4.

${ }^{148}$ LIMA, José de. “Ser professor...”, RP, Mar./Mai.,1962, p. 29.
} 
própria vida pessoal em função da docência, os professores, em particular as professoras primárias eram sujeitas a uma espécie um feitiço. Seria como se uma alquimia permeasse a sua formação e as produzisse de maneira semelhante, como se tivessem saído todas de uma mesma fôrma. Contudo, fruto de tal feitiço, viraram elas próprias as feiticeiras ao praticar a magia a que foram submetidas com aqueles a quem iriam ensinar, reproduzindo o processo com aqueles que chegavam às escolas. 


\section{Capítulo 3}

\section{PrÁtICAS ESCOLARES COM A FINALIDADE DE MORALIZAR}

Ao investigar as práticas de moralização através das fontes impressas, foi possível perceber o quanto foram diversificadas as maneiras empregadas na conformação moral dos indivíduos que estiveram presentes na escola. José Mário Pires Azanha (1991), partindo de um questionamento sobre a crise em educação, defendeu que se processasse um estudo das práticas escolares, de forma a realizar um mapeamento cultural da escola, privilegiando a sua constituição histórico-social. A respeito desse tipo de pesquisa, Azanha afirmava: "O que interessa é descrever as 'práticas escolares' e os seus correlatos (objetivados em mentalidades, conflitos, discursos, procedimentos, hábitos, atitudes, regulamentações, 'resultados escolares', etc.). Somente o acúmulo sistemático dessas descrições permitirá compor um quadro compreensivo da situação escolar, ponto de partida para um esforço de explicação e de reformulação. (...) Que interesses objetivos (mas nem sempre explicitados) se associam à formação e persistência dessas práticas?" (op. cit., p. 67) O autor questionava as reformas educacionais, defendendo que era no interior do espaço escolar que se definia o destino das políticas públicas, pela forma como os professores lidavam com as mudanças e pelas alterações nos padrões de trabalho. No seu entender, somente seria possível entender as resistências apresentadas nas conexões entre a vida escolar e as prescrições legais acerca dela mediante uma investigação que partisse de um estudo dos indícios. Segundo Faria Filho et al. (2004), ao elucidar sobre a importância de um estudo acerca das práticas escolares, Azanha "demonstrava a proficuidade do conceito na operacionalização de análises sobre a instituição escolar a partir de diferentes vertentes do conhecimento pedagógico"149. (op. cit., p. 141) Ao mesmo tempo em que as práticas

\footnotetext{
${ }^{149}$ Ao mesmo tempo em que Azanha (1991) incentivava esse tipo de pesquisa, André Chervel (1990) propunha o estudo sobre a história das disciplinas escolares e Jean Claude Forquin (1992) defendia a interação entre as dinâmicas sociais e a cultura escolar. Para Faria Filho et al., no início dos anos de 1990, dava-se início a uma reflexão que atingiria um grande número de pesquisas educacionais. A preocupação com a questão da cultura escolar passou a fazer parte dos trabalhos em história da educação por uma aproximação com a disciplina de história, pela forma de lidar com as fontes, através de levantamento e sistematização de documentos, e também "pelo acolhimento de protocolos de legitimidade da narrativa historiográfica" (op. cit., 142). Os trabalhos que fazem uso da cultura escolar como categoria de interpretação também partem de outras áreas disciplinares que compõe a pedagogia, como a sociologia da educação, a psicologia da educação, a filosofia da educação e a didática.
} 
evidenciavam elementos que constituíam o cotidiano escolar, elas também eram uma forma de exercitar a moral, consistindo num exercício para a formação de hábitos.

No período investigado, a aprendizagem da moral pelos alunos ocorreria a todo o momento da vida escolar, principalmente pela prática, mediante o modo escolar de socialização, mas nas fontes consultadas também havia a orientação para que a educação moral fosse ministrada por meio das disciplinas. A educação moral ensinada nas escolas constituía um "saber" que precisava ser incorporado e que não teria sentido fora das situações de sua mobilização. O processo de aquisição desses saberes se daria mediante a representação e a identificação e teria como resultado a ativação da prática. Nas palavras de Bernard Lahire, Daniel Thin e Guy Vincent (2001), “o corpo acredita no que representa: ele chora se imita a tristeza. Ele não representa aquilo que desempenha, não memoriza o passado, aciona o passado, assim anulado como tal ele o revive. $\underline{\mathrm{O} \text { que é aprendido pelo }}$

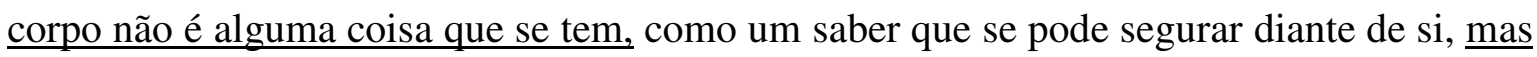
alguma coisa que se é” (op. cit., p. 24 - grifos meus). Segundo os autores, para que o corpo seja mobilizado, o indivíduo, que é dotado de história, precisa acionar o seu passado.

Com relação à moralização exercida pelo ensino das disciplinas escolares, foi possível observar ao longo da pesquisa que algumas disciplinas eram especialmente relacionadas à educação moral. Era o caso, por exemplo, de disciplinas como a história, a geografia e os estudos sociais. O ensino da música na escola também estava relacionado ao projeto de conformação moral que deveria ser exercido pela educação escolar. Havia aquelas que regularmente compunham o currículo, de caráter científico e literário, e outras ditas especiais, como a música, a educação física e o trabalho manual. As primeiras levariam os alunos a observar a "realidade" do mundo e contribuiriam para a formação de um homem moderno, realista e favorável à ação e ao trabalho. As outras contribuiriam para o florescimento da personalidade, favorecendo o esforço, o exercício da vontade e do autocontrole. Nas escolas, o conhecimento escolar ensinado por meios das disciplinas e impregnado pelos valores morais seria ministrado pelos professores. Nesse momento, o ato de lecionar os conteúdos disciplinares poderia controlado e regulado através do uso dos livros didáticos, de modo a garantir que os professores agissem conforme as normas da moral preconizada (BOTO, 1997). Os jogos também ajudariam nesta formação para a submissão às regras e ao exercício da solidariedade. Os trabalhos manuais ajudariam na perseverança, no espírito da observação e da invenção. Os centros cívicos e as cooperativas 
escolares formariam as crianças para o exercício da democracia, obrigando as crianças a organizarem-se, regulamentarem o comportamento delas mesmas e dos colegas, sancionando as irregularidades e agindo de acordo com os interesses e as necessidades da comunidade escolar. A moralização exercida pela escola através das disciplinas e mediante suas práticas evidencia que a educação moral deveria ser atendida em todo momento da vida escolar e no trabalho em comunidade.

\subsection{OS EXAMES}

Enquanto prática de conformação moral, foi possível observar que os exames poderiam ter uma função moralizadora tanto para os alunos, quando utilizados como instrumento de coerção, quanto para os professores, como forma de impor sua autoridade. Em artigo intitulado “A aprovação e a reprovação escolar", publicado na RBEP em 1956, Luiz Alves de Mattos ${ }^{150}$ dizia o seguinte: "quando a aprovação é benévola e não merecida, ela se torna prejudicial para o aluno e desmoralizante para o professor e para a escola. $\mathrm{O}$ professor perde seu prestígio e sua autoridade, suas aulas não são levadas a sério, a frequiência dos alunos decai, as tarefas não são cumpridas. É desmoralizante para a escola, cuja diretoria ou secretaria, manipula dados fornecidos pelos professores para produzir um número suficiente de aprovados, apesar de semi-analfabetos. (...) A reprovação é (...) o resultado da vadiagem mental dos alunos, quando não de sua incapacidade para aprender." (p. 255) Contudo, prossegue Mattos "essa explicação não satisfaz a didática moderna, que procura determinar as causas dessa desídia, dessa vadiagem mental e dessa relativa incapacidade. A displicência e a inabilidade técnica do professor contribuíram para criar essa situação. Porque: o professor descuidou do planejamento, acomodou-se na rotina; ignora os incentivos e procedimentos motivadores adequados; não exerceu a devida liderança no manejo da classe e o controle disciplinar; aplicou método ineficiente. Cessa a culpabilidade dos alunos e se configura a responsabilidade do professor pelo fenômeno da

\footnotetext{
${ }^{150}$ MATTOS, Luiz Alves de. (Educação, Rio) “A aprovação e a reprovação escolar” RBEP, nº 63, jul/set. 1956, p. $255-257$.
} 
reprovação em massa. Nos EUA, reprovação superior a 3\% sobre o total dos alunos a culpa é do professor; e outros lá também aumentam esse dado para 7\%. Na Rússia, o dado é a partir de $20 \%$. A juventude estudiosa não pode ser sacrificada para acobertar a desídia e a incapacidade profissional de tais professores, que felizmente são raros”. (p. 256) E conclui o autor: "não será cortando mais da metade dos jovens nela matriculados que a escola irá cumprir a sua nobre missão.” (p. 257) Em artigo publicado na RP em 1959, Mário Biagioni, Osmar Martins Cruz e José Marques Vállio ${ }^{151}$ criticavam com veemência a existência de exames finais nas escolas primárias: "os exames tem um caráter altamente imoral que se reflete em toda vida escolar. Ele mecaniza e esteriliza o ensino. Urge a supressão dos exames. (...) A educação, para ser completa, necessita dar atenção ao desenvolvimento físico, mental e espiritual do educando.” (p. 12) Em outro artigo ${ }^{152}$, publicado na RP no mesmo ano, os mesmos autores sugeriam que os exames fossem substituídos por um "boletim de merecimento", que poderia avaliar tanto o trabalho dos professores quanto o desenvolvimento dos alunos. É curioso observar que, dentre os itens que deveriam ser avaliados, estava observar o "aspecto dos alunos sob o ponto de vista da higiene - avaliação mediante observação dos alunos sob o ponto de vista da limpeza, do vestuário e do asseio corporal." (p. 22)

O psicólogo francês Pierre Gilles Weil ${ }^{153}$, em artigo publicado na RBEP em 1954, afirmava que a utilização de testes padronizados constituía-se numa das contribuições da psicotécnica à educação. A didática moderna, citada por Luiz Alves de Mattos, contava com a contribuição da psicologia para compreender o comportamento dos alunos. No entanto, a apropriação do discurso psicológico nas práticas educativas poderia ter significados antagônicos. Se, por um lado, a compreensão do comportamento poderia promover a adequação da aprendizagem de acordo com o desenvolvimento e as características individuais de cada um, por outro, os testes psicológicos poderiam dar um

\footnotetext{
${ }^{151}$ BIAGIONI, Mário; CRUZ, Osmar Martins; VÁLLIO, José Marques. "A escola primária e os exames finais" RP, mar./1959, p. 10 - 12.

${ }^{152}$ BIAGIONI, Mário; CRUZ, Osmar Martins; VÁLLIO, José Marques. "A escola primária e os exames finais" RP, mai./1959, p. $19-22$.

${ }^{153}$ WEIL, Pierre Gilles. (Atualidades Pedagógicas, São Paulo) "Psicotécnica e educação" RBEP, No 55 , jul./set. 1954, p. $176-180$.
} 
caráter técnico ao ensino, promovendo a padronização das condutas e do trabalho docente, classificando e controlando os alunos.

\subsection{A ORIENTAÇÃO DO LAZER}

No livro Introdução ao Estudo da Escola Nova, na reedição de 1965, Manuel Bergström Lourenço Filho dizia que a escola deveria considerar os ajustamentos das crianças para a vida em família, os problemas cívicos e o "bom emprego das horas de lazer" (p. 257) E ainda, afirmava que a própria extensão da obrigatoriedade procurava evitar que entre o término dos estudos primários e o ingresso no trabalho, houvesse um hiato prejudicial à formação moral e cívica, sobretudo nas cidades em que o poder educativo no lar se debilitava. As atividades realizadas durante o lazer também foram tratadas por Durkheim no livro A Educação Moral. Para ele, o lazer e o momento de descanso são sempre perigosos e a arte, se realizada como forma de recreação, só interessaria à moral porque poderia prevenir os riscos da ociosidade. Caso não fosse enquadrada, a arte também representaria um perigo à vida moral porque ela se afasta da realidade. A moral pertence à vida séria e tem o real por objeto, não deixando espaço para a fantasia e o lúdico. Desta forma, "tanto a brincadeira quanto a arte nos fazem viver em um mundo de imagens, e sabemos disso, e são essas combinações de imagens que produzem tanto o prazer da brincadeira quanto o prazer da arte. Nesse sentido, podemos dizer que a arte é uma brincadeira. A moral, ao contrário, faz parte da vida séria." (op. cit., p. 263) A idéia é que nas obrigações do trabalho e da vida adulta "séria", o indivíduo estaria protegido das más seduções, que produziriam comportamentos desviantes e abalariam a ordem social e a vida em comunidade. A arte, enquanto prática criadora, não estaria sujeita ao enquadramento estabelecido por normas e regras de controle da conduta, representando um perigo em potencial, já que são seria possível prever as suas conseqüências. Mais próxima do aspecto instintivo nos seres humanos, a arte está presente nas formas mais antigas de civilização, enquanto a moral caminha a passos largos para recuperar seu tempo na história e instituir a ordem, o autocontrole e a manutenção de práticas de civilização. 
No desenvolvimento de projetos, atividades com finalidade moral poderiam evidenciar, aos alunos, a necessidade da ordem social. Paulo de Almeida Campos ${ }^{154}$, em artigo acerca do "Seminário regional sobre planos e programas da escola primária", publicado na RBEP em 1956, informava que as escolas deveriam "preparar para a vida familiar e para o adequado emprego do tempo livre; explorar as aptidões e interesses e orientá-los aos campos mais proveitosos a ele e à sociedade; formar hábitos e atitudes valiosas, tais como pontualidade, honradez." (p. 79) O relatório ${ }^{155}$ apresentado na Conferência das Escolas para a Compreensão Internacional, publicado na RBEP em 1955, também trata da orientação do lazer. Nele, é dito que "encorajou-se o emprego das horas livres dos alunos na própria escola. A escola deve entusiasmá-los e habituá-los ao uso construtivo do tempo livre, em atividades como: atividades corais, orquestrais, literárias, artísticas, físicas, e passatempos como coleções de selos. Também é importante para que os próprios alunos dirijam e organizem essas atividades, embora supervisionadas por um professor, para exercitar a responsabilidade democrática em proveito de uma organização. (...) Responsabilidade coletiva pelo bem-estar da comunidade nacional e até internacional." (p. 150) E quanto ao emprego das horas livres dos professores, o relatório diz que "é essencial que o professor tenha descanso e recreação e são indispensáveis as férias de verão. (...) durante sua folga deve ser-lhe dada a segurança de divertir-se como homem livre". (p. 162) Com relação aos alunos, o documento dizia que "as atividades extracurriculares contribuem para o desenvolvimento equilibrado da personalidade." (p. 168)

Publicado na RBEP em 1951, o artigo ${ }^{156}$ acerca do "Seminário Interamericano de Educação Primária", promovido pela UNESCO e pela OEA, dizia que as escolas normais deveriam "preparar a normalista não só para aproveitar suas horas livres, mas também para dirigir seus alunos nesses momentos.” (p. 147) O professor Jurandir Paccini ${ }^{157}$, em artigo

\footnotetext{
${ }^{154}$ CAMPOS, Paulo de Almeida. "Seminário regional sobre planos e programas da escola primária" Trata-se do "Informe Final" do "Seminário regional sobre planos e programas da escola primária", promovido em maio, no Peru, pela UNESCO e pela OEA, visando ao estudo dos problemas relativos à generalização da ed. primária gratuita e obrigatória na América Latina. RBEP, nº 64, out./dez. 1956, p. 73 - 93.

155 "A formação de professores" Trata-se do relatório apresentado na Conferência das Escolas para a Compreensão Internacional, em colaboração com a UNESCO, em 1955. RBEP, nº 64, out./dez. 1956, p. 141 -179 .

156 “Seminário Interamericano de Educação Primária”, promovido pela UNESCO e pela OEA. RBEP, n 42 , abr./jun. 1951, p. $109-155$.

${ }^{157}$ PACCINI, Jurandir. “O jogo como recurso didático” RP, abr./jun. 1963, p. 9 - 10.
} 
publicado na RP em 1963, dizia que os jogos usados na escola com caráter "didáticoeducativo" seriam denominados "jogos de aprendizagem ou jogos de classe". Segundo o autor, os jogos de classe teriam objetivos morais: "quando aplicado corretamente o jogo de classe educa e aprimora a atitude do aluno. São vários os objetivos morais que se podem alcançar por meio dos jogos de classe: 1) Espírito de disciplina; 2) Combate a certos complexos; 3) Educação da atenção; 4) Despertar interesse pelo estudo; 5) Revigorar o espírito de solidariedade; 6) Ensinar o aluno a ser correto e leal; 7) Reavivar a simpatia pelo mestre" (p. 9). Além desses objetivos morais, os jogos também poderiam desenvolver o "espírito de disciplina": "o jogo de classe é essencialmente disciplinador. Ele condiciona o comportamento da criança ao atendimento de regras e normas que regulamentam o jogo. Aprende a criança, na vivência do jogo de classe, a sujeitar-se às sanções legalmente estabelecidas pelo regulamento do jogo e, naturalmente, a evitar essas penalidades agindo dentro da lei e da ordem, inibindo seus impulsos e paixões" (p. 9 - grifos meus). Segundo Paccini, o desejo de ganhar o jogo faria com que as crianças ficassem atentas às ordens e às recomendações dos professores, e também criariam o hábito da honestidade. Ao citar Amaral Fontoura, afirma que o "lúdico" desperta o interesse do aluno. Para o autor, a supressão da palmatória alterou profundamente o rendimento dos alunos e a sua motivação para a aprendizagem: "em termos de rendimento era muito mais eficiente o ensino no tempo das palmatórias porque, aqui, o objetivo da aprendizagem era imediato: aprender para não apanhar. Um crime didático-pedagógico, concordo, mas muito mais válido psicologicamente que os processos atuais. Suprimimos esse objetivo imediato reprovável por um objetivo remoto psicologicamente impossível. Como retornar a oferecer às matérias escolares um fim imediato que corresponda a uma necessidade real da criança? Só há um modo possível: a aplicação intensiva em classe do jogo como elemento motivador" (p. 10). Através de práticas como os jogos, seria desenvolvida a moralidade inerente às atividades das crianças em relação aos colegas, evidenciada pela necessidade de ordem dos movimentos e pelas regras. Os jogos poderiam ser explorados para essas possibilidades. Mas a escola ofereceria, sobretudo, um meio de educação moral por meio da disciplina. A multiplicação das atividades afetaria de maneira diferente as crianças originárias de famílias mais pobres. A orientação do lazer e a realização de atividades extra-escolares visaria a garantir a ocupação constante das crianças, tirando-as da influência da rua, cuja 
ação era considerada nefasta para a moralização que se pretendia desenvolver mediante a educação escolar.

\subsection{A EXPANSÃO DO ENSINO E A AUTO-EDUCAÇÃO}

Fernando de Azevedo ${ }^{158}$, em artigo publicado na RBEP em 1957, dizia que a educação integral, considerada a "base da escola paulista no período republicano", era um orgulho para os paulistas e, naquele momento, anos de 1950, a educação carecia de uma reconstrução. De acordo com o autor, a civilização é formada por uma "tábua de valores" e a sua conservação é uma "necessidade vital”, por esse motivo, também é "uma necessidade vital esse mínimo de assimilação dos indivíduos, de colaboração de forças e de comunhão de sentimentos, para lhes assegurar a unidade e a continuidade. Toda sociedade trabalha incessantemente, no conjunto de suas instituições, para modelar as gerações jovens em conformidade com seu ideal de vida e com determinados padrões de cultura e de comportamento" (p. 60). Chamando a atenção para a necessidade de se coordenar e disciplinar a ação de todas as "forças invisíveis" (rua, conversas, modas, espetáculos, relações) que "pesam sobre nós a cada momento de nossa vida" formando um "conjunto de pressões que, sem que ninguém queira, orientam, todavia a conduta", Azevedo ressaltava que a escola seria eficaz trabalhando junto com outras instituições sociais. Dos professores primários esperava-se dedicação exemplar, conformidade com um tipo de vida e de trabalho, que mais parecia uma missão. Se o ingresso nas escolas públicas de uma clientela de origem tão diversa carecia que a educação promovesse a assimilação entre os indivíduos de uma base de valores comuns, a intensa ocupação do espaço escolar também carecia de estratégias de regulação e de governo.

No início dos anos de 1950, um dos aspectos que mais marcaram o sistema educacional foi a expansão do ensino. Entre os anos de 1950 e de 1960, o país conheceu as maiores taxas de alfabetização. Isto se deve ao fato de que, a partir de 1947, foram

${ }^{158}$ AZEVEDO, Fernando de. "Horizontes perdidos e novos horizontes (A educação primária na sociedade atual)" RBEP, nº 65, jan./mar. 1957, p. $47-64$. 
instaladas classes de ensino supletivo na maior parte das cidades. De certa forma, tal ensino incentivou a matrícula em cursos profissionais ou pré-profissionais de nível primário. As classes de supletivo e as de ensino complementar (pré-profissional e profissional) em conjunto foram freqüentadas por mais de 400 mil alunos cada ano. Assim, o supletivo composto por duas séries escolares, entre 1947 e 1959, alfabetizou cerca de 5,2 milhões de alunos. A taxa de analfabetos que, em 1950, era de 50\%, atingiu 33,1\% em 1970. As mudanças na configuração do social do país foram sensíveis: a população total quase atingiu a marca dos 100 milhões, a população urbana cresceu e o índice de alfabetização tentou acompanhar a modificação do perfil populacional (BEISIEGEL, 1974; SPOSITO, 1984). No Estado de São Paulo, no início dos anos de 1960, o sistema escolar, nas palavras de Celso Beisiegel (2006) embora se defrontasse ainda com "as principais tarefas relacionadas com a adaptação qualitativa e quantitativa do ensino às novas condições materiais e morais da existência, teria conseguido (...) estender a rede de ensino primário por todo o seu território" (op. cit., p. 21). Nesse momento, o ensino primário universal e gratuito começava a tornar-se realidade porque neste Estado o processo de expansão das oportunidades de educação realizou-se pela "criação de novas escolas públicas e particulares ou pelo aumento da capacidade de oferta de vagas nas escolas já existentes, mediante a instalação de novas classes ou a ampliação do número de vagas existentes em cada uma dessas classes" (op. cit., p. 23). O ensino primário, especialmente os seus anos iniciais, vinha assumindo importância cada vez maior na formação das crianças: o estilo de vida que o desenvolvimento urbano e industrial imprimia na vida das pessoas passava a exigir da escola o exercício de funções socializadoras que antes eram atribuídas à família ou à Igreja. Embora o processo de expansão do ensino primário no caso paulista tenha sido bem sucedido, "o ritmo de crescimento" especialmente nas grandes cidades "foi tão acelerado que as providências adotadas por sucessivas administrações públicas para manter em equilíbrio a relação oferta/procura de vagas nas escolas primárias nem sempre alcançaram os seus objetivos" (op. cit., p. 29). Nessas ocasiões eram adotadas medidas de emergência para atender às solicitações, como a criação de classes em instalações provisórias. A esse respeito, é importante lembrar as considerações de Almeida Jr., enunciadas por Beisiegel, que afirmava que as administrações públicas teriam recorrido à "improvisação e à medicação sintomática. Soluções, ambas, porque fingem resolver e não resolvem (...) e também porque, permitindo que o mal se avolume tornam mais difícil o tratamento radical. Na categoria das medidas 
dilatórias em virtude das quais, por amor à qualidade de alunos, se prejudicou a qualidade de ensino, citemos, entre outras, as seguintes: 1) a supressão do quinto ano; 2) o desdobramento; 3 ) a redução do curso primário a dois anos (vigente, por sorte, durante um quatriênio apenas); 4) a oficialização do magistério leigo; 5) a facilitação dos cursos normais; 6) o tresdobramento; 7) o regime de quatro turnos; 8) a construção dos galpões escolares" (ALMEIDA JR apud BEISIEGEL, 2006, p. 44). Recorrendo a medidas dessa natureza até o início dos anos de 1970, o sistema de ensino conseguiu atender à demanda de vagas no ensino primário, mas é possível perceber que o processo de adaptação do sistema à nova e numerosa clientela escolar não ocorreu sem que houvesse conflito, seja com relação à adequação física e material dos espaços, seja com relação às diferenças de capital cultural que traziam essas crianças e também os professores primários que passaram a ingressar no magistério. No próprio campo educacional a democratização gerava também conflitos na medida em que polarizava as opiniões: de um lado, estavam aqueles que tomavam posição e defendiam a política de ampliação de vagas, de outro, estavam aqueles que a criticavam por acreditarem que, da forma como estava sendo feita, ela promovia o "rebaixamento" da qualidade do ensino (AZANHA, 1987). Segundo José Mário Pires Azanha (1987), a concepção da democratização como rebaixamento da qualidade do ensino é equivocada: "o equívoco dessa idéia reside em desconhecer que a extensão de oportunidades é, sobretudo, uma medida política e não uma simples questão técnicopedagógica. (...) A democratização da educação é irrealizável intramuros, na cidadela pedagógica; ela é um processo exterior à escola, que toma a educação como uma variável social e não como simples variável pedagógica" (op. cit., p. 41).

No Brasil, as matrículas de ensino primário e de ensino médio, entre 1920 e 1970, ultrapassaram os índices de crescimento populacional. Assim, grande parte da população que estava à margem do sistema foi incorporada. Outro aspecto importante que caracterizava a expansão do ensino no Brasil era o seu baixo rendimento interno. Apesar dos altos índices de expansão das matrículas, o sistema era incapaz de assegurar o acesso da população escolar do nível elementar de ensino aos níveis médio e superior. Desta forma, o sistema era marcado por um alto grau de seletividade, que se traduzia no fato de que a cada 1.000 alunos admitidos na primeira série da escola primária em 1960, por exemplo, apenas 56 conseguiam ingresso no ensino superior em 1971. Do ponto de vista de sua organização interna, uma modificação importante foi introduzida em 1971. Até os 
anos de 1970, o sistema compreendia quatro níveis básicos, que atendiam a diferentes faixas etárias, enquanto o ensino obrigatório restringia-se à escola primária de quatro anos. Com a Lei n. ${ }^{\circ}$ 5.692/71, a escola primária e o ginásio foram fundidos e passaram a se denominar ensino de $1^{\circ}$ grau. $\mathrm{O}$ antigo colégio passou a se chamar ensino de $2^{\circ}$ grau. $\mathrm{O}$ ensino obrigatório estendeu-se, assim, para oito anos, embora essa terminologia unificada não correspondesse a uma organização integrada das oito séries. As quatro primeiras séries continuaram a ser atendidas por um único professor, polivalente, do qual não era exigido o ensino superior, apenas formação para magistério em nível médio. As quatro séries finais do $1^{\circ}$ grau e o $2^{\circ}$ grau permaneceram divididas em disciplinas ministradas por diferentes professores e, nesse caso era exigida, ao menos formalmente, a educação superior (TANURI, 2000).

Para proporcionar o ingresso de tantas pessoas na escola, algumas práticas precisaram ser adotadas de modo a viabilizar o governo dos alunos e a organização do sistema de ensino. A idéia de "auto-educação", por exemplo, parece ser um reflexo disso. O relatório ${ }^{159}$ apresentado na "Conferência das Escolas para a Compreensão Internacional", publicado na RBEP em 1956, afirmava que a "auto-educação" seria a "marca do sucesso em qualquer formação". O documento referia-se à formação de professores e dizia que "o que se possa fazer para preparar o professor é sempre pouco diante de sua própria individualidade, e que depende de suas inclinações não só para ensinar, mas também para continuar a aprender." (p. 179) Com ênfase na "auto-educação" dos alunos, Nise Pires ${ }^{160}$, pesquisadora do INEP, em artigo publicado na RBEP em 1970, afirmava que as escolas deveriam enfatizar a formação ética do educando, assim como a educação para o trabalho, para o lar e noções de higiene: "que a escola se torne uma resposta para as necessidades da comunidade", dizia a autora. No cotidiano escolar, "as atividades devem assegurar ao educando: (...) aproveitamento do sentido formativo das atividades físicas, intelectuais, artísticas, cívicas e dos princípios éticos; (...) capacidade de estudar e aperfeiçoar-se por si, tendo condições para educar-se permanentemente.” (p. 73) A "auto-educação" poderia consistir não apenas numa resposta para as necessidades da comunidade, como dizia Pires, mas poderia ser ela própria condição para a existência da

\footnotetext{
159 "A formação de professores" Trata-se do relatório apresentado na Conferência das Escolas para a Compreensão Internacional, em colaboração com a UNESCO, em 1955. RBEP, $\mathrm{n}^{\circ}$ 64, out./dez. 1956, p. 141 -179 .

${ }^{160}$ PIRES, Nise. "Educação Fundamental”, RBEP, n 117, jan./mar. 1970, p. 63 - 73.
} 
desta. Mão-de-obra minimamente qualificada e que cuidasse de si própria exigia "autoeducação". Moysés Brejon ${ }^{161}$, professor da Universidade de São Paulo, em artigo publicado na RBEP em 1965, no qual tratava da importância da educação na preparação para o trabalho, no ajustamento e na ascensão social, dizia que a escolarização seria um importante fator de desenvolvimento sócio-econômico. Para tanto, também seria fundamental o "favorecimento da auto-educação" (p. 208).

\subsection{AS MÚSICAS E OS HINOS PÁTRIOS: EDUCANDO O OUVIDO OU “DAS EXIGÊNCIAS ARTÍSTICAS DA MORALIZAÇÃO"}

Em relação à expressão artística, é curioso observar o movimento que foi criado em torno destas práticas na escola, transformando-as no intuito de moralizar. Vivendo no terreno da subjetividade, a arte tem poder de fazer florescer a imaginação e as formas de percepção do mundo, podendo transformar as experiências vividas através dos sentimentos. A criação, a apreensão da realidade vivida, é transportada para o espectador através de um objeto concreto, de uma música, de um quadro, etc. Ao apreciar uma obra de arte, o indivíduo é levado a estimular os seus sentidos, a visão, a audição, o tato e as suas emoções, dando sentido às suas lembranças que são despertadas pelo contato com a obra. Se o artista atribui significado ao mundo por meio de sua obra, o espectador, ao contemplála, lê esses significados e é tocado por ela. Criando o que "poderia ser" e não reproduzindo "o que é", os artistas deixam fluir a imaginação. Ao lado da criação, a imaginação fará a mediação entre o vivido e o pensado, o corpo e o espírito. Desta forma, a experiência estética, por ser sensorial, tocaria a alma de cada um de um jeito particular. No entanto, é preciso aprender a sentir. O gosto pela arte não é privilégio de alguns "eleitos" que se consideram inclinados a ela como que por uma dádiva: ele é fruto também de uma formação e está relacionado a investimentos de ordem material e simbólica (BOURDIEU,

161 BREJON, Moysés. "Educação, fator de produção" (publicado inicialmente n'O Estado de S. Paulo) RBEP, nº 99, jul./set. 1965, p. 207 - 208. 
2003). Contudo, na apropriação feita pela escola, a arte, então "escolarizada", parece ter outro sentido: ela parece ser mais uma ferramenta de uso civilizatório do que um elemento de educação da sensibilidade.

Em artigo publicado na RP em 1962, sobre o canto nas escolas primárias, o professor Fernando Grohmann ${ }^{162}$ afirmava que a escola seria o "agente específico da educação social, cultural, religiosa e artística". Para tanto, dizia o autor, "devemos votar dedicado sacerdócio para preparar as crianças equitativamente. A crianças devem aprender a cantar, deve haver uma direção mais vigilante, uma orientação mais pedagógica das matérias. (...) A boa música educa o ouvido, tanto quanto a leitura de bons poetas. (...) A criança cresce sem saber cantar os hinos pátrios e aprende a cantar uma pluralidade de músicas populares. E estas não lhe foram ensinadas na escola.” (p. 5 - grifos meus) Grohmann criticava a ausência do ensino da música, justificada pelo fato de se dizer que algumas crianças não teriam "voz adequada" para isso, mas, no entanto, essas mesmas crianças cantavam nos momentos de lazer. Desta forma, seria preciso que isso fosse feito na escola. Em 1964, o mesmo autor publicou outro artigo na RP, desta vez intitulado "O problema do canto nas escolas primárias"163. Neste texto, Grohmann, citando o Programa para o Ensino Primário Fundamental (Ato no 65 de 29/8/50), afirmava que o canto "deve influir na formação do caráter, na cultura da inteligência e dos sentimentos, despertar, incentivar e desenvolver o sentimento cívico." (p. 27) As competições orfeônicas escolares teriam objetivo "cívico-patriótico-pedagógico" e cada aluno deveria ter o seu caderno de "Hinos e Poesias". Seria um caderno único para o registro de hinos e poesias. Segundo o autor, "seguindo esses passos formais, obter-se-ão resultados surpreendentes e o canto surtirá seus múltiplos objetivos tais como: tornar-se elemento disciplinador do grupo social que a classe representa; de ser fator dinamogênico para o trabalho; ser o fulcro de elevação moral, intelectual e artística; de ser um auxiliar na formação da consciência cívica, como um veículo que é das emoções de um povo". (p. 27) Assim como a música, enquanto prática moralizadora, promoveria o civismo dentro das escolas, as apresentações teatrais

${ }^{162}$ GROHMANN, Fernando M. S., “O canto nas escolas primárias”, RP, Ago./Set., 1962, p. 4 - 5.

${ }^{163}$ GROHMANN, Fernando M. S. “O problema do canto nas escolas primárias”, RP, Mai., 1964, p. 27. 
também poderiam ter essa função. Lourenço Filho ${ }^{164}$, em artigo publicado na RBEP em 1961, dizia que a dramatização de temas cívicos nas escolas poderiam despertar o interesse pela história pátria. O bandeirismo dos séculos XVII e XVIII, por exemplo, seria um "excelente tema porque tem como tema central a integração". O importante nas dramatizações, segundo o autor, seriam as atitudes que pudessem despertar, marcando o caráter nacional.

Em 1964, Carmen Dulce Marcondes Machado ${ }^{165}$, professora de música, também publicou um artigo na RP acerca do ensino musical, intitulado "Música, matéria educativa”. Segundo a autora, todos aquelas que passaram pela escola sentiam as impressões boas causadas pela prática musical: “(...) a Música, das artes a mais penetrante, é ativa auxiliar da educação no que ela tem de mais sutil, de mais humano, de mais eficiente. Na música descobrimos, por natureza, todos os fatores que dão ao indivíduo a possibilidade de se encontrar para o aperfeiçoamento de sua índole, para a correção de seu desequilíbrio na disciplina interior e para decalcar nele, perspectivas e caminhos seguros na orientação dos sentimentos e do caráter."(p. 6 - grifos meus) Aos educadores caberia dirigir as "tendências", corrigir as "anomalias" e aperfeiçoar os "dotes". Continua Machado: "sendo a Música arte do tempo, o senso visual e auditivo sempre solicitados, quando exercitados por processos convenientes, conjugados com o ritmo que a regula, embeleza e dá forma, levam todo o organismo do educando - psíquico e físico - a participar de uma disciplina reguladora dos movimentos, apaziguadora das inquietações íntimas que possibilita mais pronta assimilação intelectual. (...) Quem se beneficia dela tem seus benefícios gravados na inteligência e em nossas almas. (...) Saibam as autoridades escolher os vocacionais educadores musicais e assistirão ao desabrochar de uma nova raça." (p. 6) Ao concluir o texto, Machado sugere que o Brasil deveria aprender com os europeus a considerar a música, pois o valor da mesma é incalculável.

O artigo derivado do "I Encontro Nacional de Ed. Artística"166, publicado na RBEP em 1971, dizia que "a arte é meio de integração e individualização e forma de descoberta de valores e disciplinas essenciais à vida", sendo "a música o melhor veículo para

\footnotetext{
${ }^{164}$ LOURENÇO FILHO “Dramatização de temas cívicos nas escolas" RBEP, nº 81, jan./mar. 1961, p. 207 209.

${ }^{165}$ MACHADO, Carmen Dulce Marcondes. "Música, matéria educativa”, RP, Mai./ 1964, p. 6.

166 “I Encontro Nacional de Ed. Artística" RBEP, nº 121, jan./mar. 1971, p. 170 - 179.
} 
despertar e fixar a consciência cívico-social-artística da infância e da juventude, o professor deve estar consciente de sua responsabilidade, ao preparar seus alunos para a execução correta dos hinos pátrios e das canções cívicas.” (p. 175) O texto também informava: "que a educação musical seja incluída nos currículos escolares de todos os níveis, a fim de que seja cumprida a Lei Federal $\mathbf{n}^{\mathbf{0}} \mathbf{5 . 4 4 3}$, de 28/5/68, que determina a obrigatoriedade de aprendizagem do Hino Nacional por todos os brasileiros. Que o professor de Educação Musical de formação universitária seja também indicado para ministrar aulas de Educação Moral e Cívica, dada sua habilitação específica para atender às exigências artísticas dessa disciplina.” (p. 179) Em artigo publicado no ano seguinte na RBEP, Lúcia Marques Pinheiro ${ }^{167}$ dizia que o ensino de música deveria visar o equilíbrio emocional. Nas escolas, as artes "escolarizadas" ora serviram para contar uma história, ora para rememorar um acontecimento importante, ora para despertar o sentimento religioso ou cívico. Contudo, em todas essas possibilidades, a moralização esteve presente. Ela seria como uma finalidade pedagógica da arte.

\subsection{A LITERATURA NA CONFORMAÇÃO MORAL OU POR “UMA LEITURA SADIA E BEM ORIENTADA"}

De acordo com alguns autores que escreveram nos periódicos consultados sobre a função moralizante da literatura na escola, os contos seriam importantes para levar as crianças à emoção. Emoção e sentimento seriam competências eficazes da ação moral. No âmbito escolar, da literatura muitas vezes era extraída a "lição de moral". Contudo, tanto a poesia quanto a literatura podem inovar e subverter o código da linguagem, tornando-se um terreno fértil para a imaginação. Mas, se a ficção ajudaria as pessoas a lidar com a realidade, talvez por promover uma espécie de "fuga" dela, seria por isso que haveria a necessidade de controlá-la?

167 PINHEIRO, Lúcia Marques. "Bases para a reformulação de currículos e programas do ensino fundamental" RBEP, n 125, jan./mar. 1972, p. 10 - 31 . 
Em artigo publicado na RP em 1962, o professor José Tarcisio de Souza ${ }^{168}$ afirmou que o livro ajudava a formar o caráter das pessoas porque "na leitura de um livro a criança encontra exemplos nobres, regras de boa conduta, preceitos de higiene física e mental, instrução patriótica, conhecimentos da língua pátria, da história, da geografia do país. (...) A leitura transpõe os umbrais da escola e penetra nos lares, esclarecendo os conhecimentos adquiridos, pelas crianças, instruindo-as e contribuindo para o desenvolvimento intelectual e moral, o que é necessário para boa formação da personalidade. (...) Aqueles que zelam pela educação moral e intelectual da mocidade brasileira devem disseminar os livros nos ambientes escolares, nos lares, onde se reúnam crianças, pois a leitura sadia e bem orientada ajudará a criar na mente dos jovens de hoje o senso de responsabilidade e o amor à família, à pátria que à sua direção serão entregues amanhã década seguinte, durante o exame dos periódicos educacionais, foi possível perceber uma mudança no tom dos artigos que faziam referência à literatura na escola. Se antes a leitura dos livros, se "bem orientada", seria uma poderosa aliada da educação moral, no final dos anos de 1970 ela passou a ser contestada em relação aos sentidos que poderia criar. O preconceito veiculado em algumas histórias, por exemplo, passou a ser criticado. Fúlvia Rosemberg $^{169}$, pesquisadora da Fundação Carlos Chagas, em artigo publicado na RBEP em 1977, tecia uma crítica à "literatura edificante", portadora da moral que traria a salvação. Nestes livros, a ordem se confundiria com o bom e com o belo, e a desordem com o mau e o feio. A expressão das emoções seria "morna". Nas biografias, os personagens seriam exemplares e modelos a serem seguidos. O "bom" seria também o "sábio" e o "mau" seria o "ignorante". Os pobres pareceriam sempre enaltecer a caridade dos ricos. Publicado no mesmo número da RBEP, o artigo "A influência exercida pela literatura sobre crianças e jovens", do alemão Klaus Doderer ${ }^{170}$, diretor do instituto de pesquisa em literatura infantil e juvenil de Frankfurt, os "livros podem influenciar existências, podem desencadear processos de grupo, podem servir para sancionar atitudes e ações. Note-se a influência que Bibi Meia-longa (Pipi Langstrunpf) exerceu até mesmo sobre a moda dos jovens. Citem-se as tentativas nos regimes ditatoriais para transformar a consciência dos jovens, incutindo-lhes o ódio racial e o espírito guerreiro, valendo-se de

\footnotetext{
${ }^{168}$ SOUZA, José Tarcisio de. “O valor educativo do livro”, RP, Jun./Jul., 1962, p. 14.

${ }^{169}$ ROSEMBERG, Fúlvia. “O adulto, a criança e a literatura” RBEP, nº 141, jan./abr. 1977, p. 7 - 15.

${ }^{170}$ DODERER, Klaus. "A influência exercida pela literatura sobre crianças e jovens" RBEP, $n^{\circ}$ 141, jan./abr. 1977 , p. $17-25$.
} 
literatura ideológica, como ocorreu na ditadura fascista de Hitler na Alemanha". (p. 20) Segundo Dodorer, os personagens centrais trazem características boas, para serem imitadas pelos jovens. Desde que existe literatura juvenil há manipulação literária, através da censura, do controle da oferta de livros, de esclarecimentos unilaterais, da ênfase em certas opiniões estéticas nas escolas (normas padronizadas para o bom e o belo, o distinto e o vulgar, apresentados como valores absolutos). Ainda neste número da RBEP, a professora universitária Monique Augras ${ }^{171}$ tratava dos mitos brasileiros na literatura infantil. Para ela, a história do Barba Azul seria suavizada nos contos infantis, mostrando o personagem principal encarcerar duas mulheres em vez de degolar sete, "despindo assim o conto de suas funções básicas, a de lidar com a violência dos próprios desejos. Ensina-se à criança que deve ser 'boazinha'. Para 'não traumatizá-la' conta-se estórias em que até o lobo é 'bonzinho'. Vive-se, enfim, num mundo ‘bonzinho'. Como sentirá então uma criança que é real, que ama e odeia com a fúria própria da infância? Será que, somente ela tem a exclusividade de não ser 'boazinha'? Não se culpabilizará pelos impulsos agressivos? A fantasia do conto propõe precisamente a catarse (isto é, purga) dessa violência. Além do mais, este mundo não é bonzinho. Qualquer noticiário de televisão apresenta imagens muito mais apavorantes que as evocações dos contos, e sem os recursos mágicos das soluções heróicas.” (p. 29 - grifos meus) Desta forma, os contos e as lendas teriam o poder de exorcizar a angústia, invocando-a. "Fundamentado no progresso racionalista de Augusto Comte", explica a autora, "que considerava que as etapas teológicas e metafísicas devessem ser necessariamente superadas para chegar-se à era científica, surge conjuntamente com o desenvolvimento da sociedade industrial. O século XIX desenvolve a idéia do século precedente, ressaltando a importância dos fatores econômicos. Os sistemas de crença, os valores éticos e quiçá religiosos são então avaliados como meros decorrentes de um quadro econômico. As leis econômicas a tudo determinam: após a influência de Comte, que despreza o pensamento mítico em nome do racionalismo, aparece Marx que, afirmando o determinismo econômico, relega os sistemas de crença e o pensamento mítico como tantas elaborações compensatórias, manipuladas em termos de poder. Essa colocação é ainda vigente em muitas áreas do pensamento sociológico.” (p. 29 - 30) Para Augras, o mito, esboço de existência humana e conjunto de símbolos socialmente determinados,

\footnotetext{
${ }^{171}$ AUGRAS, Monique. “Mitos brasileiros em literatura infantil” RBEP, nº 141, jan./abr. 1977, p. 27 - 35.
} 
alcançaria ao mesmo tempo o universal e o específico: “atrás da presente barbárie, a mensagem do mito vai ao encontro de temas presentes na ideologia cristã. (...) Ensinando simbolicamente como lidar com os problemas existenciais, com a violência, a angústia, a insegurança, situando a questão da origem e da morte, os mitos antigos são sempre atuais. Longe de alienar o leitor, fazem-no mergulhar no âmago da realidade. No caso da literatura infantil, portanto, a estória mítica parece afirmar-se como um canal privilegiado de educação e de aculturação". (p. 33 - 34) A universalidade do mito, conclui a autora, seria também um meio de integração com a humanidade inteira.

Desta forma, os discursos veiculados por pesquisadores nos periódicos consultados, principalmente durante a década de 1970, alertavam para a maneira como a literatura vinha sendo utilizada, que trazia os perigos da doutrinação e da educação estética unidirecional. Com finalidade moralizadora, a dicotomia apresentada na literatura infantil poderia incutir nas crianças um pensamento classificatório, como se só existissem duas visões, o bom e o mau, o belo e o feio, e não houvesse a diversidade, como se o mundo fosse dividido assim. Em nome da moralização, a maneira como a literatura era trabalhada nas escolas parecia não deixar espaço para o desenvolvimento da imaginação e da criatividade. Em artigo publicado na RBEP em 1976, o poeta Carlos Drummond de Andrade dizia o seguinte: "Por que motivo as crianças, de modo geral, são poetas e, com o tempo, deixam de sê-lo? Será a poesia um estado de infância relacionado com a necessidade de jogo, a ausência de conhecimento livresco, a despreocupação com os mandamentos práticos do viver - estado de pureza da mente, em suma? Acho que é um pouco de tudo isso, e mais do que isso, pois, se ela encontra expressão cândida na meninice, pode expandir-se pelo tempo afora, conciliada com a experiência, o senso crítico, a consciência estética dos que compõe ou absorvem poesia. Mas, se o adulto, na maioria dos casos perde essa comunhão com a poesia, não estará na escola, mais do que em qualquer outra instituição social, o elemento corrosivo do instinto poético da infância que vai fenecendo à proporção que o estudo sistemático se desenvolve, até desaparecer no homem feito e preparado supostamente para a vida?" (p. 593-594). Nesse sentido, pensando que o processo de socialização estrutura o desenvolvimento cognitivo, a expressão da criatividade estaria relacionada com a conformação moral, podendo ser inversamente proporcional a ela. 


\subsection{OS MUSEUS E A HISTÓRIA PÁTRIA: “O MUSEU COMO SISTEMA DE MEMORIZAÇÃO VITAL À CONTINUIDADE DO PROCESSO CIVILIZATÓRIO”}

Ao longo do exame das fontes consultadas, os museus também apareceram veiculados nos discursos acerca das práticas de moralização. O professor Paulo de Almeida Lencastre $^{172}$, em artigo publicado na RP em 1959, elogiava Sólon Borges dos Reis pela iniciativa de criar os museus históricos e pedagógicos do Estado de São Paulo, o que auxiliaria na formação de uma "vigilante consciência cívica da juventude e da mocidade paulista". Desta forma, "Sólon atenderia a uma das mais prementes necessidades da escola brasileira - o ensino do civismo, tão vital e infelizmente tão descurado entre nós." (p. 32) Em artigo publicado na RP, escrito em 1961, o professor primário José Geraldo Leme da Silva ${ }^{173}$ dizia que naquele tempo, em que a escola se integrava cada vez mais à sociedade, era necessário motivar o ensino: instruir preparando o educando para a vida no meio social. Para tanto, Silva dizia que "ocupar alunos nas bibliotecas e museus infantis é procurar transformar a escola numa verdadeira sociedade, é preparar para a vida as crianças. Os castigos físicos e a palmatória abafavam a personalidade do indivíduo, matando-o em seu próprio benefício. O papel do professor é viver com as crianças, participando de suas alegrias e de seus dissabores. Educar não é instruir. (...) Museu-pedagógico, jornal e biblioteca escolar: com bons livros teríamos então o verdadeiro preparo para a vida, evitando desse modo a mágoa, o dissabor, de no futuro vermos uma dessas almas infantis, transviadas para o caminho do mal e da perdição.” (p. 23) Noêmia Varella ${ }^{174}$, diretora da "Escolinha de Arte do Brasil", localizada no Rio de Janeiro, em artigo publicado na RBEP em 1979, dizia que "o mais importante era que se permitisse à criança perceber a existência do museu como sistema de memorização vital à continuidade do processo civilizatório" (p. 324).

Se o museu poderia contribuir para a formação cívica das crianças, o mesmo ocorria com o ensino de história pátria. Em artigo ${ }^{175}$ publicado na RBEP em 1963, que

\footnotetext{
${ }^{172}$ LENCASTRE, Paulo de Almeida. "Os museus históricos e pedagógicos" RP, nº 43, jan./1959, p. 32.

${ }^{173}$ SILVA, José Geraldo Leme da. "Educação: preparo para a vida”, RP, Jul./Set., 1961, p. 22 - 23.

${ }^{174}$ VARELLA, Noêmia. "Projeto: A criança e o museu" (diretora-geral da Escolinha de Arte do Brasil - RJ) RBEP, n 143 , jan./abr. 1979, p. 323 - 325.

175 "Notas para a história da educação" - Decreto n n $^{\circ}$ 981, de 8-11-1890, constante dos currículos para a "Escola Primária" de $1^{\circ}$ e $2^{\circ}$ graus, Benjamim Constant. RBEP, nº 91, jul./set. 1963, p. 181 - 195.
} 
fazia referência à história da educação e trazia o decreto $\mathbf{n}^{\mathbf{0}} \mathbf{9 8 1}$, de 8-11-1890, com informações relativas ao currículo das escolas primárias, a disciplina "História Pátria" estava associada à "Instrução Moral e Cívica". A primeira deveria trabalhar com "biografias de personagens ilustres" e a segunda deveria "fazer com que os alunos sintam a grandeza das leis morais, comparação entre generosidade e egoísmo, atividade e preguiça, prazeres e dores (físicas e morais, higiene física e moral, família, deveres de pais e filhos, amos e criados, respeito da honra e da reputação alheia, pátria, deveres e direitos do cidadão)”. (p. 195) Para Daniel Marsh ${ }^{176}$, em artigo publicado na RBEP em 1953, o professor poderia "inculcar idéias nas jovens mentalidades, e até muitas idéias, ventiladas racionalmente, que servirão de base à sua conduta presente e futura; e a mocidade não pode prescindir delas, mesmo que tenha noção de sua origem" (p. 114). E os conhecimentos de história ajudariam a "talhar e moldar a vida da nossa República. As escolas, as igrejas e as instituições dedicadas à cultura do conhecimento e à promoção da sabedoria são as mais fortes defesas da nossa Pátria”. (p. 114) Em artigo publicado na RP em 1960, Acácio de Vasconcelos Camargo ${ }^{177}$ dizia o seguinte: “o professor deve se mostrar patriota, o ensino de História da Pátria é importante porque a escola é uma mistura de raças e deve ser orientada para o progresso, o civismo e a grandeza. A boa escola deve formar hábitos. Atualmente a boa educação não começa em todos os lares, daí o valor relevante da escola primária e em seguida secundária, para que se formem pessoas dignas da família, da sociedade e da Pátria. Do cidadão competente, honesto e patriota depende a felicidade do Brasil." (p. 15 - grifos meus) Em artigo sobre a orientação educacional e a lei de diretrizes e bases publicado na RP em 1962, Agostinho Minicucci ${ }^{178}$, dizia que, dentre as atribuições do Gabinete da Educação, estariam: "levar o aluno a compreensão dos mais altos valores da vida social; acentuar e elevar na formação espiritual dos adolescentes o amor pelos grandes feitos da História da Pátria, bem como pelos ideais da Nação Brasileira; suscitar entendimento pessoal com os alunos em entrevistas individuais, para ouvi-los sobre seus desajustes no Colégio, no lar e na vida social; realizar tudo quanto possa auxiliar o desenvolvimento moral do aluno.” (p. 33) A educação moral e cívica e a história pátria

\footnotetext{
${ }^{176}$ MARSH, Daniel L. (Revista do Professor - São Paulo) "Dignidade da profissão de ensinar" RBEP, no 49, jan./mar. 1953, p. $114-117$.

${ }^{177}$ CAMARGO, Acácio de Vasconcelos. “A missão do professor” RP, nº 57, ago./set. 1960, p. 15.

${ }^{178}$ MINICUCCI, Agostinho. “A orientação educacional e diretrizes e bases”, RP, Jun./Jul., 1962, p. 33 - 34.
} 
teriam objetivos bastante próximos. Para o professor Olivio de Araujo ${ }^{179}$, em artigo publicado na RP em 1963, tanto a história pátria quanto a geografia estariam a serviço da educação cívica. Ele dizia o seguinte: "destaca-se esta matéria (educação moral e cívica) por ser a única que conduz a criança à compreensão e ao discernimento entre o bem e o mal. Ela apresenta fatos históricos e figuras dignas de serem imitadas. Para a educação cívica, há motivos nas aulas de História Pátria e de Geografia. As festas também não devem ser dispensadas. Para a cultura moral, é preciso desenvolver nos alunos o uso da liberdade com responsabilidade. Compreender os deveres para com a Pátria. O uso de histórias, fábulas e provérbios é indispensável para o desenvolvimento da Educação Moral e Cívica.” (p. 32) A aquisição das noções que comportam cada matéria, que não se propõe simplesmente a fixar na memória conhecimentos verbais, exige o desenvolvimento de certas atitudes mentais, como pensar historicamente e cientificamente, se exprimir de forma reflexiva respeitando um sistema complexo de regras e controlando as atitudes mentais adquiridas, que também se expressam no comportamento dos indivíduos.

\subsection{A HOMOGENEIZAÇ̃̃̃O E A CULTURA COMO “INSTRUMENTO DE COMUNHÃO”}

Se a homogeneização poderia auxiliar o trabalho dos professores, ajudando-os a ensinar e a disciplinar muitos alunos ao mesmo tempo, ela não era restrita apenas ao cotidiano escolar. Em artigo publicado na RBEP em 1973, Anísio Teixeira ${ }^{180}$ chamava a atenção para o grau de homogeneização a que vinha chegando a vida em conseqüência dos processos maciços de produção e de organização, que a estavam modelando. Tais processos homogeneizavam a casa, o vestuário, a religião, o pensamento, e atingiriam todos os aspectos da vida. De acordo com o autor, "a situação educacional ainda não tem homogeneidade necessária para que nela identifiquemos uniformidades. Cada situação é uma só e só pode ser comparada com ela própria” (p. 59). Para o psicólogo francês Pierre

${ }^{179}$ ARAUJO, Olivio de. "Instrução moral e cívica”, RP, Jan./Mar., 1963, p. 32.

${ }^{180}$ TEIXEIRA, Anísio. “'Systems Analysis’ e Educação” RBEP, nº 129, jan./mar. 1973, p. 57-59. 
Gilles Weil $^{181}$, em artigo publicado na RBEP em 1954, que também defendia a utilização dos testes padronizados, as turmas homogêneas facilitavam o ensino. Em artigo publicado na RP em 1959, Valace Marques ${ }^{182}$, diretor de grupo escolar, chamava a atenção para as circulares que faziam "de tudo para uniformizar o trabalho na escola". (p. 5) O professor Lannoy Dorin ${ }^{183}$, em artigo publicado na RP em 1962, criticava a tentativa de "padronização das capacidades" dos alunos: "dada a impossibilidade de conseguirmos classes homogêneas, como abaixo se verá, façamos a nossa. (...) o que tem feito com sucesso é a padronização das capacidades, o que, em termo sociológico, significa mediocrização. (...) Dividir a classe em três secções pode resolver o problema do professor mas a educação não existe em função dele e sim dos alunos e da sociedade. Não estimulará a maioria. A péssima formação do professor talvez seja a responsável por isso. Se lhe faltam subsídios teóricos, a prática é um desastre.” (p. 25)

Para Lourenço Filho ${ }^{184}$, em artigo publicado na RBEP em 1952, “é a cultura geral que leva os homens a fixar seus valores sociais e morais, é no campo da cultura geral que devemos debater os destinos da nação. Que poderão as instituições educativas - como tais considerados o lar, a escola, a igreja, - se o ambiente humano, enfraquecido em seus controles de natureza moral e, em grande parte, justamente pela aplicação da técnica a certas formas de comunicação e difusão industrializada, caminha para a desagregação?” (p. 134) Para o autor, da "má utilização" da imprensa e da publicidade decorreriam tendências menos salutares à vida moral. O educador pouco poderia fazer diante de "meios de difusão tão poderosos". Seria preciso "admitir que o Estado precisa ater-se às formas de degradação da cultura e à invalidação dos valores que formam o próprio caráter nacional." (p. 135) Em artigo intitulado "O homem moderno e o humanismo", publicado na RBEP em 1957, o professor universitário Afrânio Coutinho ${ }^{185}$ dizia que o humanismo buscava o melhor ajustamento do homem a si mesmo, o seu perfeito desenvolvimento físico, moral,

\footnotetext{
${ }^{181}$ WEIL, Pierre Gilles. (Atualidades Pedagógicas, São Paulo) "Psicotécnica e educação" RBEP, № 55 , jul./set. 1954, p. $176-180$.

${ }^{182}$ MARQUES, Valace. "Administradores de alto nível” RP, mar./1959, p. 5.

${ }^{183}$ DORIN, Lannoy. “Acerca das secções 'A', 'B' e 'C'”, RP, Ago./Set., 1962, p. 25 - 27.

${ }^{184}$ LOURENÇO FILHO “A educação nacional e o novo projeto de lei” RBEP, no 48, out./dez. 1952, p. 124 $-137$.

${ }^{185}$ COUTINHO, Afrânio. "O homem moderno e o humanismo" RBEP, nº 65, jan./mar. 1957, p. 16 - 27.
} 
estético e espiritual; seria o esforço pelo aprendizado moral, para melhorar o homem como pessoa, como membro ativo da comunidade. "O conceito vazio de cultura", afirmava o autor "em que se distinguiu a civilização burguesa, foi a causa da desmoralização do espírito e da atividade intelectual, da crise da verdade, de nossos dias. A cultura é um instrumento de comunhão. Individualismo desmoralizante. As humanidades resumem magnífica experiência psicológica e moral. Fruição da vida moral e contemplativa, que são bens supremos do universo." (p. 27)

A influência da Escola Nova trouxe um tratamento diferenciado às questões educacionais, renovando as formas tradicionais de ensino, antes baseadas nos castigos e na memorização. O movimento almejava que a escola tivesse uma função socializadora, para além de ensinar a ler, a escrever e a contar, ela deveria educar para a vida. A educação deveria ser renovada, adaptada para uma civilização que estava em constante mudança, e que fosse capaz de harmonizar a dicotomia existente entre as classes sociais, criando a ilusão de uma unificação cultural. Para tanto, fazia-se também necessária a expansão do ensino e a difusão da escola elementar. Para promover a reconstrução social e a moralização do povo, coube à educação a tarefa de homogeneização cultural. Lourenço Filho, signatário do Manifesto dos Pioneiros da Escola Nova (1932), defendia que a escola deveria promover a unificação cultural, a integração do estrangeiro, a moralização das classes, com o objetivo de eliminar os valores negativos que pudessem impedir o progresso, a organização nacional e homogênea da sociedade. Ao criar os Testes ABC para verificação da maturidade necessária à aprendizagem da leitura e escrita (1933), o educador pretendia organizar a população desordenada que iniciava os estudos todos os anos. Apresentados como a possibilidade de estabelecer uma classificação inicial dos alunos que chegavam às escolas primárias, esses oito testes buscavam "medir a maturidade" das crianças em relação ao aprendizado da leitura e da escrita, de modo a facilitar o início do trabalho dos professores. A partir de seus resultados era possível dividir a população em três grupos de crianças considerados homogêneos: fortes, médias e fracas. O grupo forte seria capaz de aprender a ler e a escrever sem dificuldades em apenas um semestre, o grupo médio aprenderia normalmente no prazo de um ano letivo e o grupo fraco não conseguiria aprender no prazo estabelecido a não ser em condições especiais, com atendimento individualizado e em classes com um número reduzido de alunos. Para Lourenço Filho, a homogeneização dos grupos seria importante para prevenir a frustração, 
que levaria ao sentimento de inferioridade entre as crianças mais imaturas. Esse seria um ponto fundamental na defesa da seleção das classes, já que os sentimentos de segurança, de auto-estima e de confiança nos professores eram considerados imprescindíveis para o sucesso da aprendizagem. Além disso, as classes selecionadas, ao garantirem maior eficiência ao ensino da leitura e da escrita, melhorariam o rendimento do ensino primário, o que significaria a diminuição no número de reprovações e traria economia para os cofres públicos, onerados pelos encargos das reprovações. Condições psicológicas das crianças como maturidade, motivação e auto-estima, eram consideradas questões educacionais e políticas. Segundo Ana Laura Lima (2007), “os testes aparecem como uma tecnologia de governo que permite equacionar ambos os problemas: o de promover condições mais adequadas ao ensino e o de evitar o desperdício de recursos públicos causado pelo excesso de reprovações na primeira série. (...) as classes homogêneas permitiriam uma avaliação mais justa do trabalho docente, visto que, pelo sistema regular, sem que se conhecesse o número de crianças maduras e imaturas em cada classe, os professores que tinham a má sorte de receber maior número de alunos imaturos eram julgados pelos mesmos critérios daqueles que recebiam alunos mais maduros, o que constituía uma injustiça porque, claramente, o desempenho dessas classes não poderia ser igual” (p. 150). Desta forma, a configuração das classes homogêneas, ao adequar as expectativas de rendimento de cada classe ao seu "nível de maturidade", pretendia favorecer também uma avaliação mais justa em relação ao desempenho profissional dos professores diante de cada turma. Assim, os testes concebidos por Lourenço Filho serviam não apenas ao governo dos alunos, como também ao governo dos professores.

\subsection{DOS CASTIGOS FÍSICOS AO MANEJO DA CLASSE}

Se, sob a moral religiosa, as condutas eram controladas pelo temor e pelo amor a Deus, diante de uma moral laica qual seria o freio que conteria as paixões? Em uma "escola sem Deus", a moralidade passou a se fundar na construção do espírito da disciplina e do amor à pátria, sendo preciso ligar as crianças à pátria, fazendo-as amar um ideal social ao qual pudessem dedicar sua devoção e sacrifício. "Na sociedade moderna, a fome 
poderia ser saciada graças à vinculação dos indivíduos a três grupos sociais que Durkheim seleciona como objetos do desejo: família, pátria, humanidade. Mas os objetos são hierarquizados de modo a privilegiar um deles: a pátria. (...) Por outro lado, à medida que a sociedade progride e se centraliza, a vida familiar adquire importância menor enquanto a vida do grupo político (vida comum a todos os seus membros) é a que atrai o indivíduo ligando seu desejo a outros objetos. Como o centro da gravidade da vida moral deslocou-se para um novo objeto, a família tornou-se um órgão secundário do Estado.” (FERNANDES, 1994, p. 95)

Apesar das escolas conservarem em sua forma elementos monásticos, o castigo físico como prática educativa vinha sendo contestado e recebia várias críticas. O professor Luiz Horta Lisboa ${ }^{186}$, em artigo publicado na RP em 1960, afirmava que o castigo físico não interessava mais à escola, pois poderia alterar o sistema nervoso das crianças, mas ele ainda era praticado nos lares. Segundo Lisboa, o fato de tal prática ter sido banida das escolas não traria como conseqüência uma "mocidade débil e viciada", porque isso "sempre existiu". A eliminação do castigo não significaria negligência em relação ao comportamento dos educandos, que deveriam ser orientados com "dedicação e amor" pelos seus responsáveis. Posição semelhante expressava a professora Cinéa Vieira Ramos ${ }^{187}$, em artigo também publicado na RP, no ano de 1959: "para a formação moral da criança, pouco ou nada contribuem os castigos muito humilhantes, que produzem a revolta e a rebeldia. Os castigos podem provocar uma reação desfavorável, lesando a formação moral. (...) A criança é em geral dócil e sempre pronta a agir, para o bem ou para o mal, de acordo com a situação e o estímulo que recebe”. (p. 9) Na mesma revista e no mesmo ano, o professor primário José Dias de Aguiar ${ }^{188}$ publicou um artigo no qual apresentou uma posição bastante distinta. Para ele, a obra de Rousseau, O Emílio, aniquilou a moral da sociedade por "divinizar" a infância. Referindo-se ao filósofo como inimigo do adulto, Aguiar diz que "a intranqüilidade de uma alma boêmia não poderia representar uma formação moral que se aplicasse à educação. (...) Agora temos uma mocidade de porcelana, mocinhos quebráveis, amarelos pelo uso da maconha e dos vícios sexuais, de

\footnotetext{
${ }^{186}$ LISBOA, Luiz Horta. "Educar com castigo físico?”, RP, jun./1960, p. 40.

${ }^{187}$ RAMOS, Cinéa Vieira. “A disciplina na escola”, RP, dez./1959, p. 9 - 10.

${ }^{188}$ AGUIAR, José Dias de. “O castigo físico”, RP, jan./1960, p. 31- 32.
} 
cabelos revoltos, camisa espalhafatosa, calças extravagantes, sapatos inconfortáveis e gritantes, silhueta grotesca. O chicote ainda deveria existir nos lares. Juventude doida. No caso do Lar, da Casa Cristã, o castigo físico precisa existir. É preciso moldar a criança, puxando-a pelo braço no caminho adverso da vida. Abandoná-la é deixar que seja devorada pelos anos. Se não fizermos isso, teremos uma Pátria de bonecos luxuosos, despersonalizados, banais." (p. 31 - 32) Ao final do artigo há uma nota dizendo que o CPP não concorda com o castigo físico como meio de educação. A função do castigo seria a de empreender um reforço negativo cada vez que o indivíduo apresentasse uma conduta desviante, que poderia ser representada por uma lição não realizada ou mal feita, uma agressão ao colega ou à professora. A palmatória, um dos símbolos do castigo físico, vinha sendo contestada e, gradativamente, abolida do espaço escolar. Contudo, os castigos psicológicos, além de continuarem em prática, eram cada vez mais sofisticados por uma certa tecnologia do poder que impregnava o cotidiano escolar, moldando e normatizando as condutas (FOUCAULT, 1994).

A psicologia ingressou no campo educacional brasileiro em um momento marcado pelo "entusiasmo" pela educação pública. No início do século XX havia uma crença, por parte dos educadores e dos governantes, que através da educação seria possível construir o espírito cívico e a identidade nacional (NAGLE, 1976). Em 1912, o governo paulista trouxe o psicólogo italiano Ugo Pizzoli para organizar o primeiro laboratório de psicologia experimental na escola normal "Caetano de Campos", evidenciando os esforços empreendidos pelo Estado para reestruturar e aparelhar o sistema público de ensino. A aproximação da psicologia com a educação almejava fazer da pedagogia um conhecimento cientificamente válido, apropriando-se das técnicas, das teorias e dos métodos elaborados por aquela ciência para justificar e tentar legitimar as suas próprias práticas (TAVARES, 1996). Segundo Fausto Tavares (1996), a criação destes laboratórios satisfazia a dois tipos de exigência: a necessidade sentida pelos administradores e educadores públicos em aparelhar as escolas com órgãos modernos para sua a maior eficiência, fornecendo apoio técnico eficiente para o trabalho do professor com os alunos e a necessidade de associar as práticas pedagógicas com as técnicas científicas da psicologia, aproveitando-se do estatuto que esta nova ciência já possuía entre os intelectuais na Europa e nos EUA. Influenciadas pelo ingresso da psicologia no campo educacional, as escolas passaram a fazer uso de testes que tinham por objetivo medir e classificar os alunos, submetendo todos a um padrão 
de normalidade: aqueles considerados como desviantes deste padrão, considerados por vezes como "crianças-problemas"189 precisariam ser tratados e corrigidos (LIMA, 2004).

O século XX, também considerado como o "século da criança" inventou a figura do aluno e contou com contribuição da psicologia para isso. Esta, por sua vez, acabou por exercer uma função de controle do comportamento das pessoas, contribuindo para a construção "científica" de um padrão de conduta e de normalidade. De acordo com Jorge Ramos do Ó (2001), a incorporação de princípios morais através de uma prática definida como a da autonomia funcional e da liberdade, surge como a marca mais distintiva e consensual da escola. Neste momento, a disciplina é, de fato, um exercício crescentemente solitário e associado à independência ideal do aluno: as regras que permitem a vida coletiva já não se impõem pela violência das sanções, pela rigidez dos princípios, e nem sequer podem ser ensinadas pelo professor; ao contrário, cada um está obrigado a inferi-las, a descobri-las em relação ao mundo exterior, mas que deve ter a sua origem e o seu termo dentro dos limites do indivíduo. Para o autor, "liberdade e autoridade são descritas como realidades simbióticas: o discurso pedagógico projeta um ideal-tipo de estudante independente-responsável. É aquele que pode e deve medir as conseqüências tanto dos seus atos como das formas de conduta através de regras interiores que resultam das suas experiências pessoais, quer dizer, de uma adaptação espontânea à vida escolar. (op. cit., p. 8-9) Assim, o "ser moral" só poderia ser suscitado se o aluno fosse levado a pensar e sentir sobre a regra imposta. A análise do "governo dos escolares" em Portugal, empreendida pelo autor, é feita a partir da perspectiva da governamentalidade de Michel Foucault. O seu objetivo é entender como certos aspectos da conduta da coletividade e dos indivíduos começaram a merecer a atenção e a ser problematizados por autoridades muito diferentes, tentando diagnosticar em momentos históricos específicos o que as autoridades quiseram que acontecesse. Portanto, trata-se de um trabalho acerca da diversidade das linhas de pensamento, de idéias e de crenças que associam a ordem social - a economia, a sociedade ou a política - com a moralidade e a subjetividade. Desta forma, são as redes de inteligibilidade, os quadros de ação e de associação que permitem que o governo, nas sociedades modernas, ocorra à distância.

\footnotetext{
${ }^{189}$ Um pormenorizado estudo acerca da expressão "criança-problema" nos discursos educacionais foi realizado por Ana Laura Godinho Lima: $O$ espectro da irregularidade ronda o aluno: um estudo da literatura pedagógica e da legislação sobre a "criança-problema", tese de doutorado, FEUSP, 2004.
} 
Controlar a alma dos indivíduos fazia parte da dimensão moralizadora da psicologia. Se ela moldava a conduta, previa o comportamento e as reações das pessoas, ela o fazia mediante a conformação moral: o indivíduo somente participava deste processo a partir do momento em era levado a agir, a pensar e a sentir segundo as regras impostas. Aqueles que não fossem adequadamente moralizados - conhecidos como "desajustados", "anormais", "delinqüentes", "rebeldes" - consistiriam em desvios do padrão estabelecido e poderiam tornar aquela previsão não mais possível. O governo de si era fundamental para a conquista do governo de todos. Nas práticas educacionais, o conhecimento trazido pela psicologia acerca do comportamento humano substituiu o castigo físico pelo controle da alma ao criar nos indivíduos a responsabilidade por regular o próprio comportamento: mediante o processo de moralização, o medo e as dores derivados do uso da palmatória deram lugar à formação da vontade, ao autogoverno e a sentimentos como a culpa e a vergonha, que levariam as pessoas a se auto-corrigirem. As crianças, por sua vez, deveriam submeter-se livremente à correção dos seus defeitos, mediante uma adesão refletida às regras impostas a elas. Além disso, nas escolas primárias, os alunos também deveriam submeter-se pelo amor e pela confiança destinados aos seus professores, especialmente às professoras primárias que, ao serem levadas a suprir as carências trazidas pelas crianças, inclusive afetivas, representavam a figura materna, como foi visto no capítulo anterior.

As crianças consideradas desajustadas, "inadequadas", impróprias, que não aceitavam o controle pretendido pelas escolas, poderiam ser "tratadas". Com a influência da psicologia na educação, os castigos físicos deram lugar ao discurso e ao exemplo da figura docente para controlar as condutas e conformar moralmente os indivíduos. Em artigo publicado na RP em 1961, o professor João Grigolon ${ }^{190}$ criticava os castigos físicos como forma de correção para as crianças indisciplinadas, "faladoras", "irriquietas": "o bom mestre com os conhecimentos de Psicologia não poderá de maneira alguma admitir que a correção, bem como, que o bom aprendizado, se faça a custa da palmatória. (...) O professor hábil e bom, levará seus planos ao respeito mútuo, sem necessidade da força muscular, isto é, com bons exemplos apenas e bons modos. O exemplo é o mais poderoso dos mestres. (...) A melhor lição de educação que se pode dar às crianças, é praticar à vista delas as virtudes que se lhes ensinam. (...) Diante de certas crianças que se tornam intoleráveis em classe, o

\footnotetext{
${ }^{190}$ GRIGOLON, João. "Castigos físicos: o bom exemplo e a força do mestre”, RP, Mai./Jun., 1961, p. 9.
} 
professor habilidoso com as qualidades de orientador e de educador deve antes de tudo investigar as causas perturbadoras desses elementos, as quais poderão vir de certas deficiências físicas, tais como: - de audição, de visão, perturbações orgânicas, complexos de inferioridade ou de superioridade, tratamentos inadequados dos pais, vícios aprendidos com outros colegas, etc. Uma vez descobertas as causas, então se procurará os remédios apropriados para o mal, e o educador será como que o 'médico escolar'. Não é com gritos ou com pancadas que se educa, o professor também não deverá elevar a voz acima do normal, para ministrar as suas aulas. Como um líder, deve sempre procurar saber dos desejos de seus discípulos, aprovando os bons e desaconselhando os errados, sem desprestigiar a personalidade do educando. A criança crê na palavra do mestre mais do que qualquer outra pessoa. $\mathrm{O}$ professor tem força suficiente para vencer a criança sem precisar castigá-la. Porque o castigo traria danos para a sua vida futura. Para conseguir-se das crianças a correção dos seus defeitos, dever-se-á, em primeiro lugar amá-la e em segundo lugar evitar todo o excesso na correção dos seus erros de uma só vez. Com essa educação, a criança submeter-se-á aos poucos à correção dos seus defeitos.” (p. 9 - grifos meus) A criança se submeteria à disciplina não pelo medo, mas sim pelo amor. Tratar-se-ia de adesão racional e desta forma mais eficiente. Mediante os discursos veiculados tanto nas revistas quanto nos manuais, é possível perceber que, ao ser condenado, o castigo deu lugar a outras práticas que visavam à conformação moral dos alunos. $\mathrm{O}$ manejo, por exemplo, seria uma delas. Acompanhando a idéia do autogoverno, ele também teria por objetivo viabilizar a educação das massas. Francisco Pássaro ${ }^{191}$, que era professor primário, em artigo publicado na RP em 1960, ao condenar o castigo, dizia que o manejo ou a direção da classe seria o governo exercido pelo professor sobre o ambiente da sala de aula, para poder desenvolver o seu trabalho: "é o clima necessário ao rendimento escolar, é a técnica que garante a disciplina, a ordem, o desenvolvimento harmonioso necessário" (p. 40). Ele citou Dom Bosco acerca do manejo preventivo: "examinar a indisciplina pela raiz, no momento em que ela nasce, e o professor, sem que o aluno perceba, o leva à mudança de atividades, uma vez que se verifica, na falta de sintonização com o trabalho, toda a vadiagem mental. Os resultados educativos tem por finalidade a formação de hábitos de boa conduta individual e social e a formação de atitudes" (p. 40). Entre as normas práticas do manejo, está aquela que sugere que o professor não deve assumir atitudes vulgares e nem dar aos

${ }^{191}$ PÁSSARO, Francisco. "É fácil manejar uma classe” RP, jun./1960, p. 40. 
alunos excesso de confiança. Em artigo ${ }^{192}$ publicado no ano seguinte, na mesma revista, intitulado "A criança, esperança da pátria, nos aspectos educativos", o autor diz que "o alvo da disciplina é produzir o ente que se possa governar a si mesmo" (p. 32). O autor citou a Escola Nova por não tolerar a liberdade desenfreada, mas também por não admitir meios coercivos e de coerção, que só serviriam para aniquilar a vivacidade e a vontade do educando. A escola seria o lugar no qual as crianças ensaiariam "os primeiros passos para entrosarem-se no meio comum. É na escola que o mundo se desacortina para a criança. É a escola que infiltra no espírito infantil os sentimentos superiores para o embate da vida com o mundo, e por isso, deve propiciar a disciplina na liberdade, ministrar a moralidade das atitudes, mostrar o trilho da realidade, enfim, encaminhar o aluno com ensinamentos sadios, para uma completa formação de caráter" (p. 33). Ao sugerir a colaboração entre pais e mestres, diz que "o ambiente familiar desajustado ocasiona graves prejuízos ao espírito das crianças. São umas mimadas, outras odiadas ou escorraçadas. Desfalecem nos primeiros choques da realidade e o seu fracasso social é enorme" (p. 33) Novamente o autor critica os castigos corporais, que seriam a explosão da cólera de pais mal formados e humilhariam os seus filhos. E o autor indagava: "quais são as reações na alma da criança? vergonha, raiva, vingança, despeito" (p. 33). Segundo Pássaro, a "Escola Nova é o baluarte, o anteparo dessas anormalidades, porque ela satisfaz as tendências de sociabilidade do educando, advertindo-o dos males e mostrando a necessidade de cooperação de que fazem parte a solidariedade, a perseverança e a firmeza do mestre" (p. 33). O professor Euvaldo de Oliveira Mello ${ }^{193}$, em artigo publicado na RP em 1960, dizia que para ensinar o mestre impõe uma conduta que julga adequada: as crianças devem ficar sentadas na posição correta, silenciosas, autônomas, preparadas para obedecer ordens. Desta forma, "a criança automatiza-se, a personalidade do aluno se anula quase completamente. Na escola nova a disciplina é dinâmica. Os alunos podem se mover e trabalhar em grupo. A criança deve sentir que a escola é dela e foi feita para ela. Não deve sentir separação entre as atividades na escola e fora dela. A escola nova prega a autonomia, vai criando pouco a pouco uma autoridade interna, uma regra, uma norma de conduta de si próprio, em substituição àquela autoridade externa, de coação e repressão. Não significa que as crianças fazem o que

\footnotetext{
${ }^{192}$ PÁSSARO, Francisco. “A criança, esperança da pátria, nos aspectos educativos” RP, mai./jun., 1961, p. $32-33$.

${ }^{193}$ MELLO, Euvaldo de Oliveira. “A disciplina na escola primária” RP, fev./1960, p. 8.
} 
querem mas que querem o que fazem. Só assim poderemos fornecer homens de iniciativa, capazes de governarem a si próprios " (p. 8 - grifos meus).

Nascida na França em 1899, a partir do projeto do pedagogo francês Edmond Demolins (1852 - 1907), que pretendia criar uma escola considerada "nova", capaz de formar as novas elites, preparando as crianças, que deveriam ser agentes de sua própria educação, para a vida prática, a "École des Roches" visava à formação de um homem novo (DUVAL, 2009). Essa experiência inicial faz parte de um movimento conhecido como Escola Nova que se espalhou pelo mundo nas décadas seguintes. No Brasil, ele começou a esboçar-se nos anos de 1920, época marcada pelo crescimento industrial, pela imigração e pela expansão urbana. Nestas condições históricas e sociais, um grupo de intelectuais que contava com nomes como o de Anísio Teixeira, o de Fernando de Azevedo, o de Lourenço Filho, entre outros, difundiu o movimento no país, tomando a educação como algo que precisaria ser revisto e remodelado para que a sociedade pudesse estar preparada para acompanhar esse desenvolvimento social e econômico. Os ideais da Escola Nova, ao defenderem a formação integral, uniforme, obrigatória e comum para todas as crianças e ao incentivarem tanto o trabalho coletivo quanto o trabalho individual para garantir o bemestar do grupo, incutiriam nos alunos a sensação de dever para com os outros e despertariam sentimentos de solidariedade mediante o cumprimento de responsabilidades que garantiriam o bom funcionamento da comunidade. O projeto escolanovista visava a contribuir para a configuração de um modelo de escola que, ao cuidar da educação, almejava cuidar também da organização do povo em uma sociedade industrial que estava em expansão. Sob a influência da biologia e da psicologia, e educação renovada promoveria a adaptação das crianças às novas condições sociais (CARVALHO, 2001). Concebendo-as como agentes de sua própria educação, cabia ensinar a elas como fazer o uso racional da liberdade. $\mathrm{O}$ Manifesto dos Pioneiros da Educação Nova, publicado em 1932, que teve como redator Fernando de Azevedo, defendia a universalização de uma escola pública, laica e gratuita e que esta fosse organizada como uma "comunidade de vida", baseada nos princípios da solidariedade, da cooperação, da ação e da liberdade. As crinças deveriam ser estimuladas pelos professores a desenvolver o seu trabalho com prazer mas também para sacrificarem-se pelo "bem de todos". De acordo com o documento citado, a Escola Nova não seria um aparelho de instrução, mas buscaria desenvolver uma educação integral, e proveria, de forma articulada, a 'educação física, moral e cívica', desenvolvendo também nas crianças 
hábitos higiênicos, despertando o "sentido da saúde", a resistência e "vitalidades físicas", a "alegria de viver" (AZEVEDO, 1932). Foi possível perceber ao longo do exame das fontes consultadas para este estudo, que os ideais trazidos pelo movimento da Escola Nova nos anos de 1920, ingressaram no pensamento pedagógico e estiveram presentes nas representações e nas práticas de moralização nas escolas públicas paulistas até o final dos anos de 1970. Ao defender que os alunos trabalhem não só para si, mas principalmente pelo grupo, submetam-se racionalmente às regras estabelecidas e administrem a própria liberdade, o que as escolas criam, mediante suas práticas, é um dispositivo de ordenação política que tem a necessidade do autogoverno em sua essência. Ao tomar o aluno como o centro do processo de ensino e aprendizagem, a educação escolar o faz agente de sua própria educação e, como tal, ele deve aprender a governar-se, a disciplinar-se e a controlarse. Nas escolas, a liberdade não é oferecida impunemente: ela é dada também com um objetivo pedagógico, para que se aprenda a utilizá-la. Não é por acaso que, quando os autores dos artigos e dos livros consultados fazem reverências às práticas escolares originadas pela educação renovada, o prefixo "auto" normalmente antecede o verbo: autoeducar, auto-disciplinar, auto-defender, auto-controlar, autogovernar. Se na escola tradicional a disciplina era alcançada mediante o uso de instrumentos de coerção, como a palmatória e os castigos físicos, que condicionariam o corpo, na escola renovada a moralização era privilegiada, formando a vontade, ensinando a "querer" o precisava ser feito, condicionando a alma. Aldo Perracini, no manual pedagógico A escola renovada, publicado em 1972, definia como "balbúrdia" o comportamento dos alunos após a condenação da palmatória, o que privou os professores de um instrumento de ação eficaz para a obtenção da disciplina. Sem o castigo físico como maneira de chegar à coerção, Perracini sugeria então que os alunos fossem mantidos ocupados a maior parte do tempo enquanto estivessem na escola, pois "o estudante ocupado não pode ser indisciplinado" (p. 115). Além disso, os professores ainda deveriam "manter a disciplina pelo exemplo" (p. 147). Neste momento, fortemente influenciados pela idéia de uma escola renovada, os autores sugeriam aos docentes que alcançassem a auto-educação no aluno e a autodisciplina. Para o autor, "a verdadeira disciplina consiste em levar a criança a desejá-la, ela implica sempre num grau de restrição dos impulsos espontâneos e naturais da criança" (p. 167). Desta forma, a pessoa disciplinada seria aquela que tivesse alcançado "força autônoma" da atenção e do interesse. 
Ainda acerca do comportamento dos alunos, foi possível observar que até mesmo a alimentação era considerada enquanto um fator que poderia alterar a conduta infantil. Segundo o professor Tulio Expedito Liporoni ${ }^{194}$, em artigo acerca das causas dos desajustamentos infantis, publicado na RP em 1960, a criança desajustada seria aquela diferente do seu meio social, que não vivia de acordo com os padrões adotados pela sociedade. Seria desajustada em relação aos padrões da "norma da conduta infantil". A falta de alimentos repercutiria no sistema nervoso, no fígado e no cérebro e, por esse motivo, as crianças subnutridas aprenderiam mal. Elas seriam "apáticas, derrotistas e preguiçosas". Além do fator nutricional, outros elementos também causariam o "desajustamento”: “(...) aluno de outra raça numa classe que lhe parece estranha também pode se tornar desajustado. Menina criada com meninos e vice-versa também pode se tornar desajustada. Nas causas sociológicas está a família, porque é nela que as crianças recebem as primeiras impressões globais. Dos atritos, violências e separação dos pais, podem surgir a criança tímida, agressiva, medrosa, indiferente. Nos grupos de recreações, vizinhanças, as crianças vivem na vadiagem. Antes de qualquer punição, é necessário investigar as causas do desajustamento." (p. 21 -22) Segundo o autor, para resolver o problema do desajustamento de algumas crianças à escola, certas medidas deveriam ser tomadas: "a criança pode ser encaminhada a um psiquiatra, pediatra, ou ação conjunta entre pai e educador, para sanar esse desajustamento.” (p. 22) Liporoni inicialmente chama a atenção para a desnutrição como um dos elementos causadores dos desajustes no comportamento infantil. A sua posição é partilhada pelo educador Valdomiro Pires Camargo ${ }^{195}$, em artigo publicado na mesma revista no ano anterior. Ao tratar de fatores que influenciariam o rendimento escolar, o autor afirma que os alimentos nutritivos oferecidos pelas escolas aos alunos visavam à sua saúde, para que pudessem ser mais assíduos e aplicados nos estudos. Contudo, “às vezes esses pequenos vadios, preguiçosos e indolentes são apenas vítimas da alimentação deficitária, do dentes cariados e da anemia e da verminose. Todo ser doente entra para dentro de si e seu estado psíquico ou moral vai sofrendo modificações." (p. 7 - grifos meus) O professor Waldemar Vieira dos Reis ${ }^{196}$, em

\footnotetext{
${ }^{194}$ LIPORONI, Tulio Expedito. “Causas dos desajustamentos infantis”, RP, mar./1960, p. 21 - 22.

${ }^{195}$ CAMARGO, Valdomiro Pires. “As instituições como fatores do rendimento escolar”, RP, dez./1959, p. 7.

${ }^{196}$ REIS, Waldemar Vieira dos. “A escola e a alimentação da criança”, RP, Dez., 1960, p. 37 - 38.
} 
artigo publicado na RP em 1960, dizia que nas escolas primárias as crianças deveriam aprender a formar bons hábitos de alimentação e os professores deveriam ensinar sobre a conduta à mesa. De acordo com Reis, "é na infância que mais facilmente se formam e se enraízam os hábitos. (...) É bem verdade que o leite, a carne, a manteiga, por serem alimentos caros é mesmo impossível aparecer nas mesas dos nossos operários, mas infelizmente, para nossa vergonha, não dispensam eles o seu maço de cigarros e o seu aperitivo; os filhos, os sorvetes, balas, doces e guloseimas fora de hora. A pobreza obriga à promiscuidade; residências anti-higiênicas e alimentação escassa concorrem muito para o nosso atraso. A influência do ambiente é decisiva na formação da personalidade. Outrora se atribuía à herança essa calamidade, sabe-se hoje ser devido ao meio em que se desenvolve e vive o ser humano a maior causa." (p. 37) Segundo o autor, os professores deveriam transmitir noções de higiene e "vigiar" o desenvolvimento das crianças, porque "nas camadas pobres, as crianças andam pelas sarjetas, sujas e semi-nuas, aprendendo vícios e palavrões, em completo abandono. Devido a esse desamparo, quando essas crianças chegam à escola, muitas delas levam consigo os mais nocivos hábitos que passaram a fazer parte de sua personalidade em formação. A quem cabe essa tarefa importante de cuidar da criança? Ao professor, não se discute”. (p. 38) Sobre os pais que iam à escola tirar satisfações com os professores e com os funcionários acerca do tratamento dispensado aos seus filhos, Reis dizia: "o professor primário passa por tudo isso, mas abnegado como é, permanece indiferente aos ataques que lhe são lançados pela massa ignorante. Ele age como o Cristo. Perdoa tudo e ainda traz, nos lábios, um sorriso amigo às suas crianças..." (p. 38 - grifos meus) Comparado a Cristo, o professor primário era visto como o Salvador que seria capaz de redimir a população de seus vícios e maus hábitos mediante a educação das crianças. Associada à promiscuidade, para além das questões econômicas, a pobreza também seria um mal e desta forma deveria ser combatida porque ela era amoral. É possível perceber através de discursos como estes que estão citados acima que a abertura das escolas às massas promoveu um choque de capitais social, econômico e cultural - entre os professores, os funcionários e entre a própria clientela escolar, que se tornou mais diversificada em sua origem. E deste choque surgiu um estranhamento que era visível mediante um discurso que atacava a moral, o que é possível depreender através dos próprios termos utilizados para designar essas crianças mais pobres e seus pais: "vadios", "preguiçosos”, "indolentes”, etc. A afirmação de Reis, ao dizer que "a pobreza obriga à promiscuidade", evidencia um discurso determinista que 
fadaria o indivíduo ao fracasso mediante a sua origem, caso ele não passasse pela escola, instituição responsável pela sua "salvação" e que tentaria eliminar as marcas de sua vida doméstica e familiar.

Para alguns autores, a conduta desejável aos alunos ainda poderia ser baseada em automatismos, que representariam a incorporação, pelos alunos, dos mecanismos de controle dos comportamentos - no lugar da palmatória, seria acionada a vergonha, por exemplo. Em artigo publicado na RBEP em 1956, Luiz Alves de Mattos ${ }^{197}$ discutia a importância dos exercícios como procedimentos de fixação de automatismos. Ele definia automatismos como hábitos, destrezas e habilidades que exigiriam tanto dos professores quanto dos alunos o emprego de recursos e procedimentos diversos para a aprendizagem "ideativa" ou para a formação de padrões de conduta de "fundo emotivo", como ideais, atitudes, apreciações estéticas e valorizações éticas e sociais, preferências. O exercício consistia na repetição intensiva e regular dentro de várias situações, até que se atingisse o grau de perfeição desejável. Mattos discordava de alguns autores, por darem injustificada amplitude de aplicabilidade a tais procedimentos: "Comenius, há 300 anos, discriminava com bastante precisão o processamento didático diversificado a ser dado às destrezas, aos conhecimentos e aos sentimentos e atitudes morais". (p. 58) A prática repetitiva só tornarse-ia valiosa quando obedecesse a princípios psicológicos que governassem este tipo especial de aprendizagem, o automatismo. Para tanto, os professores deveriam orientar os alunos a economizar suas energias de modo a aplicar somente aquela necessária à realização do trabalho, "liberando os demais músculos que não estejam envolvidos na ação". Caberia aos professores assegurar as condições psicológicas necessárias para sua plena eficácia e conduzir os alunos "inteligentemente, pautando-se pelas normas técnicas sugeridas pela Didática moderna". A propósito da formação da conduta das crianças referenciada nos artigos publicados nos periódicos examinados ao longo dos anos de 1970, esse discurso parece ter sido fortalecido mediante a justificativa psicológica, que chamava a atenção para a importância da educação infantil e pré-escolar. Além disso, com a emancipação feminina crescente, era preciso valorizar o lugar no qual as crianças deveriam ser deixadas enquanto a mãe estivesse trabalhando, as creches e as escolas de educação infantil.

${ }^{197}$ MATTOS, Luiz Alves. "O exercício como procedimento de fixação de automatismos", RBEP, no 62, abr./jun. 1956, p. $56-74$. 
Em artigo publicado na RBEP em 1976, o professor espanhol Manuel Pallarés ${ }^{198}$, tratava da conduta social e da adaptação na idade pré-escolar. Segundo o autor, as condutas fazem parte de um processo e representam tendências predominantes, cujo sentido é dado pelo momento evolutivo que as precede e pelo que as segue. A experiência familiar determinaria diferenças individuais na orientação inicial. $O$ tipo de relação que seria estabelecido com grupo condicionaria o desenvolvimento posterior da personalidade. As crianças que freqüentassem a pré-escola seriam mais sociáveis e independentes, mas os efeitos benéficos da assistência pré-escolar dependeriam do carinho, da amabilidade e da dedicação dos professores. A agressividade demonstrada por algumas crianças seria manifestação de insegurança, de falta de auto-estima ou de ciúmes. O estímulo gerado pela competição, considerado benéfico, levaria as crianças a descobrir suas limitações e a superar "traços indesejáveis" de sua personalidade: quando a "competição chegasse a extremos", criaria sentimentos de inadequação nas crianças "menos capazes". Além disso, Pallarés também apresenta no texto uma certa tipologia dos alunos. Os traços ligados ao prestígio social seriam: "bonito, asseado, empreendedor, responsável, sincero". As crianças rejeitadas, por sua vez, seriam apáticas, rebeldes e "brigonas", além de serem individualistas, brincarem sozinhas e ignorarem o chamado dos outros. Também com um enfoque psicológico, a professora universitária Amélia Domingues de Castro ${ }^{199}$ publicou um artigo na RBEP em 1974 acerca dos fundamentos da didática, com enfoque piagetiano, no qual discute a questão da orientação da conduta infantil. Para Castro, a "energia" da conduta seria originada de necessidades e interesses nos quais não se encontra apenas o fator fisiológico ou afetivo, mas também o fator cognitivo. "Mas, tanto a energia que desencadeia a ação e orienta a conduta, quanto a estruturação da atividade, promovem seja a adaptação às coisas (em que pode predominar a necessidade intelectual de compreender, explicar), seja a adaptação aos outros (em que podem predominar os sentimentos). Predomínio e não exclusividade.” (p. 15) “A vida social, por introduzir o 'outro' e sua perspectiva, obriga o indivíduo a distinguir-se dele (física, representativa e socialmente) e a um esforço de reformulação do conjunto 'eu-e-outro'. Na conduta e no plano intelectual, é por meio do convívio no grupo que se desenvolve o 'controle mútuo', ou seja a

\footnotetext{
${ }^{198}$ PALLARÉS, Manuel. "Conduta social e adaptação na idade pré-escolar”, RBEP, nº 140, out./dez. 1976, p. $540-555$.

${ }^{199}$ CASTRO, Amélia Domingues de. "Fundamentos psicológicos da didática. Enfoque piagetiano", RBEP, n 133 , jan./mar. 1974, p. $9-21$.
} 
necessidade de justificar e verificar, objetivamente, ações e pensamentos. É assim que modalidades específicas de atuação grupal, como a discussão, a troca de idéias, a colaboração no jogo e no trabalho, tornam-se importantes para o desenvolvimento do pensamento. 'A lógica', diz Piaget, 'é a moral do pensamento, imposta e sancionada pelos outros' (assim, como diz o psicólogo, a moral é a lógica da ação).” (p. 19) De fato, a conduta dos alunos era objeto de atenção de vários autores, mesmo tratando dos mais diferentes temas. Lúcia Marques Pinheiro ${ }^{200}$, coordenadora da Divisão de Aperfeiçoamento do Magistério do Centro Brasileiro de Pesquisas Educacionais/INEP, quando escreveu sobre a reformulação de currículos e programas do ensino fundamental em 1972, dizia que a educação fundamental deveria proporcionar, no núcleo comum de seu currículo, o desenvolvimento de aspectos harmoniosos da "pessoa humana" e o progresso social, entendido não apenas como desenvolvimento material, mas como a "elevação do homem como ser moral". Em toda obra educativa, irão se destacar os objetivos da formação social e moral, de desenvolvimento de atitudes de cooperação, solidariedade, justiça, tolerância, objetividade e otimismo. Para a autora, o essencial era que os professores não se preocupassem tanto com os conteúdos tratados, mas sim com a "mudança de comportamentos, a aquisição de interesses permanentes e de responsabilidade social". Neste mesmo número da RBEP, Cora Bastos de Freitas Rachid ${ }^{201}$, técnica de educação do MEC, também falava a respeito da conduta dos alunos, mas o fazia por outro viés: a necessidade da escola de $2^{\circ}$ grau estimular e aperfeiçoar "condutas de trabalho", desenvolvendo hábitos e atitudes que visariam à formação profissional e que deveriam ser incorporados à personalidade, como cooperação, disciplina, lealdade, etc.

A formação moral realizada mediante discursos psicológicos e voltada para a perspectiva do autogoverno chamou a atenção durante todo o exame das fontes consultadas. A influência dos pedagogos do início do século XX, que buscavam construir escolas modelares, tendo como objetivo o princípio do "self-government", do autogoverno, ficou explícita nestes textos. Construído historicamente, o governo de si é o resultado do avanço das tecnologias do poder. No período que compreende os séculos XVII e XVIII, o

\footnotetext{
${ }^{200}$ PINHEIRO, Lúcia Marques. "Bases para a reformulação de currículos e programas do ensino fundamental”, RBEP, nº 125, jan./mar. 1972, p. 10 - 31 .

${ }^{201}$ RACHID, Cora Bastos de Freitas. "Habilitações profissionais da área terciária", RBEP, no 125, jan./mar. 1972, p. $97-109$.
} 
corpo foi descoberto como objeto e alvo de poder. Michel Foucault (1994), em Vigiar e Punir, trata da questão da disciplina e da forma como ocorreu o processo de sujeição dos corpos às ordens e ao adestramento. $\mathrm{O}$ autor discorre acerca da formação do soldado, que afirma ter sido "fabricado" mediante um treinamento que o deixou eficiente como uma máquina. Todos os seus gestos eram calculados para que agisse na hora exata, com precisão. O corpo passou a ser visto como algo a ser modelado e treinado. Contudo, este treinamento era conquistado através de pequenos gestos e não de grandes ordens. Nesta perspectiva, a disciplina não é algo que sempre existiu da mesma forma, conquistada mediante tantos detalhes, ela passou a contar com tantas prescrições quando foi dada uma maior ênfase ao corpo: “o momento histórico das disciplinas é o momento em que nasce uma arte do corpo humano, que visa não unicamente o aumento de suas habilidades, nem tampouco aprofundar sua sujeição, mas a formação de uma relação que no mesmo mecanismo o torna tanto mais obediente quanto é mais útil e inversamente." (op. cit., p. 127) Este treinamento ao qual são submetidos os corpos consiste na disciplina, encontrada não apenas em quartéis, como também em escolas, hospitais, igrejas, famílias, enfim, em todas as instituições formadas pelos homens, onde há sempre um poder a ser exercido, uma ordem a ser cumprida. A disciplina tem o poder de colocar ordem, controlar pessoas, organizar espaços: "importa estabelecer as presenças e as ausências, saber onde e como encontrar os indivíduos, instaurar as comunicações úteis, interromper as outras, poder a cada instante vigiar o comportamento de cada um, apreciá-lo, sancioná-lo, medir as qualidades ou os méritos. Procedimento, portanto, para reconhecer, dominar e utilizar. A disciplina organiza um espaço analítico.” (op. cit., p. 131) Nesse período, para que a prática disciplinar se efetivasse, eram utilizadas "micropenalidades", sanções que visavam fazer com que o indivíduo as incorporasse até que pudesse agir da forma esperada, sem que fosse preciso verbalizar ou efetuar tal sanção. Trata-se de processos sutis, com castigos leves, privações temporárias ou pequenas humilhações que sinalizam que a postura assumida está errada. Há ainda a recompensa, que reforça o bom comportamento através da oferta de medalhas, elogios e presentes. Mediante as sanções exercidas, positivas ou negativas, o comportamento daqueles que as sofrem tornam-se homogeneizados. Cada um passa a atuar de acordo com aquilo que foi interiorizado, com o que foi estabelecido enquanto padrão esperado, e "normal", de comportamento. A disciplina, seja ela utilizada na escola, no hospital, o exército ou em qualquer outra instituição, com a finalidade de formar hábitos adequados, gestos eficientes e impor ordem, pelo poder que ela exerce 
sobre as pessoas, ela também humilha, exclui, reprime e censura. Controlando a diversidade, os mais afetados nesse processo seriam os diferentes, aqueles que se desviassem do padrão estabelecido.

Segundo Jorge Ramos do Ó (2001), a noção de governamentalidade é estabelecida entre: “(i) a 'microfísica do poder', ligada às tecnologias políticas do corpo e à aplicação de técnicas disciplinares nas prisões; (ii) as preocupações gerais da soberania política, direcionadas para gestão das nações, populações e sociedades no quadro de relações institucionais; (iii) as estratégias estabelecidas para a direção e condução de indivíduos livres, fazendo equivaler as 'práticas do eu' com as 'práticas do governo'. (op. cit., p. 14) $\mathrm{O}$ desenvolvimento de uma tecnologia que iria associar ao Estado uma multiplicidade de formas de governo implicou na existência de todas as suas práticas. Assim, o ato de governar é entendido como um exercício permanente que entrecruza os comportamentos de todos de um mesmo modo. A disciplina e o controle sobre os indivíduos não se dá a partir da coerção ou do constrangimento exercidos sobre aqueles que são governados, mas sim a partir de uma dinâmica na qual a autonomia e a liberdade estão cada vez mais presentes, formando os cidadãos. A liberdade é, então, uma condição para a existência do poder. No Brasil, em 1969, as Prescrições sobre currículos e programas de Educação Moral e Cívica nos três níveis de ensino (Art. $4^{\circ}$ do Decreto-Lei 869/69), orientava que o exercício da autodisciplina e a prática do autogoverno deveriam intensificar-se gradualmente no nível médio (p. 33) e o educando deveria ser levado a usar a liberdade com responsabilidade, "alicerçada não apenas em princípios intelectuais, mas na consciência bem formada capaz de estabelecer freios internos para a conduta altruísta e nobre, disso resultará a permanente autodisciplina" (p. 34).

Em 1954, Afro do Amaral Fontoura, na reedição do livro Fundamentos da Educação, bastante influenciado pelos ideais escolanovistas, evidencia a importância das práticas de moralização, da conquista da ordem, da disciplina e do autocontrole serem exercidos através do autogoverno dos alunos. A instituição escolar denominada conselho de monitores é indicada como a responsável por zelar pela boa disciplina escolar e desenvolver o "espírito de autogoverno" (p. 219) A educadora italiana Maria Montessori (1870 - 1952) é citada por defender que a disciplina deve ser imposta pela própria criança a si mesma. Graças ao interesse despertado pelo trabalho escolar ela deve conseguir o domínio de si. (p. 95) John Dewey é citado a propósito da educação renovada que, baseada 
na psicologia, tem como princípio o respeito à personalidade do aluno. A auto-correção também é defendida como prática a ser incorporada no cotidiano escolar: cada um deve verificar e controlar o próprio trabalho. Ainda nesta vertente do cuidado e do controle de si, evidenciados pelo prefixo "auto", que é bastante comum em todo o livro, Fontoura afirma que as crianças precisam ter autodeterminação: elas só conquistariam sua liberdade quando conseguissem dominar, pela disciplina interior, os próprios instintos. $\mathrm{O}$ autor considera que a verdadeira liberdade é disciplina de si mesmo: acostumar-se a ela equivale a habituar-se a suportar a dor. Desta forma, a disciplina que a educação aspira a realizar é a subordinação livre, voluntária, a uma ordem exterior reconhecida como socialmente útil e moralmente boa. O educador alemão Paul Geheeb (1870 - 1961), criador da "École d'Humanité", que funcionava sob o regime de autogoverno dos alunos, também é citado.

Brisolva de Brito Queirós, no livro Didática do ensino primário: prática de ensino, que em 1960 estava na $7^{\text {a }}$ edição, valoriza a importância do autocontrole para a imposição da moral na escola e conta com a postura do professor para conquista deste ideal. Para ela, os professores devem se preocupar com os problemas de formação da personalidade e a possibilidade de influir melhorando-a ou disciplinando-a. A saúde física é considerada um dos principais "deveres" do professor. Para ela, "um organismo sadio é a base de uma personalidade dinâmica e estável. Repouso e diversão adequadamente dosados são essenciais, vida regular. Uma boa postura é um exemplo para as crianças ao seu cargo". (p. 13) Anos mais tarde, essa questão também estaria presente nas Prescrições sobre currículos e programas de Educação Moral e Cívica nos três níveis de ensino (Art. $4^{\text {o }}$ do Decreto-Lei 869/69): "se a escola apresenta ambiente de respeito, trabalho, ordem e responsabilidade, as noções de hierarquia, autoridade e autodisciplina dos alunos emergem naturalmente. Os educadores por excelência - pais e mestres - devem formar pelo exemplo que oferecem ao educando. Formação do caráter: cônscio da fundamentalidade do bom exemplo, sempre temente a Deus, o educador não esquecerá que a criança irá gravar, qual chapa fotográfica virgem, as reais disposições de caráter e emocionais dos mestres" (p. 22). Os professores são orientados ainda a não apontarem "limitações morais" nos alunos: o comportamento da criança deve ser sempre observado, pois indica o ajustamento ou o desajustamento. Segundo Queirós, a formação de hábitos morais seria conquistada mediante o reforço das atitudes positivas e a eliminação das negativas. Em algumas partes do livro, a autora apresenta questões, que também 
funcionam para enquadrar e controlar o comportamento docente, e visam identificar se as atitudes do professor está auxiliando na construção de práticas disciplinadoras das crianças. Ela pergunta, por exemplo: "a professora manifesta cordialidade com as crianças de bom comportamento e boa apresentação?” (p. 30), “o comentário da redação parecia conduzir os alunos a aquisições de hábitos de ordem e limpeza?" (p. 59), "as crianças revelaram hábitos e atitudes de honestidade, cortesia, autocontrole e autocrítica? (p. 96)

Fortemente marcado pela psicologia, o livro Introdução ao Estudo da Escola Nova, que em 1965 estava na $11^{a}$ edição, escrito por Manuel Bergström Lourenço Filho, propõe que as práticas educativas devam ser realizadas objetivando a conquista da paz entre as pessoas e dirige uma atenção especial à formação da personalidade dos educadores. Os ideais da Escola Nova compreendem a questão psicológica, o domínio de si, o autocontrole, o autogoverno e visam a cumprir uma função cívica: manter o Estado e defender a pátria. A criança é vista como um ser dotado de certa plasticidade, que sofre a influência do ambiente e pode ter sua personalidade moldada através do processo educativo. O comportamento infantil deve ser regulado através da aquisição de hábitos desejáveis, mas "o controle da conduta dos seres humanos deve ser administrado de dentro, do interior”. (p. 62) Citando a Moral Magna, do filósofo Aristóteles, o autor afirma que os impulsos da ação das pessoas deveriam ser subordinados ao conhecimento que cada um tivesse das consequiências dos seus atos, determinando assim a sua responsabilidade moral. Quanto à integração das crianças ao espaço coletivo: os sentimentos de pertencimento, segurança e auto-estima são despertados a partir do momento em que surgem sentimentos de aprovação ou de reprovação por parte do grupo. Para Lourenço Filho, a intenção de educar pressupõe a possibilidade de modificar o comportamento do educando (p. 60). Em relação à educação moral, ela deveria ser "exercitada de dentro para fora" (p. 162), mas o comportamento seria moldado mediante "recompensas e sanções positivas, castigos e sanções negativas". O pedagogo francês Edmond Demolins (1852 - 1907), fundador da "École des Roches", primeira experiência com os métodos ativos em uma escola francesa, é citado por defender uma disciplina escolar mais branda: "a maneira de estimular os discípulos não seria fazer competirem entre si, mas a emulação que cada educando deveria estabelecer consigo mesmo". (p. 160) Característica do movimento renovador da educação, o ensino misto é defendido: meninos e meninas devem conviver para que adquiram “domínio de força física e moral” (p. 162). A escritora sueca Ellen Key (1849 - 1926) é 
citada por defender que a formação moral deva exercitar-se de dentro para fora: "recompensas proporcionam aos espíritos criadores a possibilidade de aumentar a sua criação; ordem e higiene; progresso individual e social” (p. 164).

Afro do Amaral Fontoura, no manual pedagógico intitulado Didática Geral, que em 1965 estava na sua $8^{a}$ edição, afirmava que o educador deveria cuidar da alma do aluno. Partilhando dos princípios da Escola Nova, ele também sugere que a educação moral deva exercitar-se de "dentro para fora, pela experiência e pela prática gradual do sentido crítico e da liberdade" (p. 131), defende a educação integral e o respeito à personalidade do aluno. Para ele, o professor deve ser formado com uma educação voltada para a alma: ele deve ser idealista e procurar trabalhar pelos outros. Maria Montessori também é citada por acreditar que "sem liberdade não pode haver o desenvolvimento da personalidade". (p. 117) A prática da leitura é apresentada como um veículo que pode transmitir valores morais e pela possibilidade de criar uma consciência sadia na criança. Paul Geheeb também é citado por defender a auto-educação e acreditar que só o indivíduo educa a si mesmo, "toda educação é auto-educação" (p. 163). Segundo Fontoura, como a partir de 1920 os castigos tornaramse inaceitáveis, então surgiram as "motivações negativas" de ordem psicológica, como "o desprezo e o gelo" (p. 368). Práticas como estas teriam como objetivo o controle disciplinar e o enquadramento moral dos indivíduos. Para Fontoura, o conjunto das qualidades morais, intelectuais e sociais se chama personalidade. Se o professor souber "cuidar adequadamente da formação da personalidade dos alunos, não terá problemas na aula”. (p. 494) A atenção à personalidade dos alunos também é evidenciada no livro de Luiz Alves de Mattos, o Sumário de didática geral, que em 1967 estava na $7^{\text {a }}$ edição. Para ele, o professor seria o "técnico da engenharia humana" responsável pela formação da personalidade dos alunos e a aprendizagem só teria sentido quando fosse capaz de operar essa transformação. A escola "moderna" deve promover o autogoverno dos alunos, que teriam a tarefa de elaborar um código de "boa conduta" (p. 396) Jacques Maritain é citado novamente por defender a disciplina interiorizada. Como exercício para desenvolver a compostura individual, a disciplina e o bom comportamento em grupo, as excursões eram indicadas.

A tarefa de cuidar de si próprio e da auto-educação também é evidenciada por Aldo Perracini, no livro A escola renovada, de 1972. Na escola "renovada", as normas e as sanções deveriam ser estabelecidas pelos alunos através da conscientização, da 
autodisciplina e do diálogo: "a verdadeira disciplina consiste em levar a criança a desejá-la, ela implica sempre num grau de restrição dos impulsos espontâneos e naturais da criança. (...) A pessoa disciplinada é aquela capaz de alcançar força autônoma da atenção e do interesse". (p. 167) Claparède é citado por defender as diferenças individuais: "é preciso levar em conta as diferenças de aptidões. O fenômeno da rejeição tem imensa importância moral e social. Como queres que a criança aprenda a amar o trabalho quando se lhe faz executar tarefas para as quais não tem aptidão e nas quais está certa do fracasso?” (p. 14) O inglês Paul Nash (1889 - 1946) é citado por acreditar que "a disciplina sempre implica num grau de restrição nos impulsos espontâneos ou naturais da criança". (p. 167) Essa idéia de que a educação escolar precisaria auxiliar a criança a conter os seus impulsos para modificar o seu comportamento também é escrita por Imideo Giuseppe Nérici, no livro Ensino renovado e fundamental, que em 1975 estava na sua $5^{\text {a }}$ edição. Para ele, a educação seria capaz de modificar o comportamento do homem. E livre seria aquele que soubesse controlar os seus impulsos e que determinasse uma orientação responsável ao seu comportamento social. A disciplina seria um ponto de chegada e não de partida - os alunos deveriam incorporá-la ao seu comportamento para a realização dos trabalhos escolares e para a vida em sociedade. A formação do senso sócio-moral e o conhecimento dos valores deveriam orientar o comportamento social. Os impulsos naturais deveriam ser disciplinados, a fim de possibilitar um melhor "relacionamento na vida social" (p. 88). A auto-avaliação é apresentada como uma prática que pode referir-se ao controle das formas de comportamento na esfera pessoal, social e aos conhecimentos do educando, que deveriam ser "apreciados por ele mesmo" (p. 116). O autor apresentou inclusive uma "ficha de comportamento social", que seria destinada a levar o aluno a apreciar a sua conduta com relação a ele mesmo e às pessoas de seu convívio (p. 117). As fichas trazem prescrições, perguntas sobre pontualidade, asseio, comportamento e julgamento de valores, como, por exemplo, se a criança é mentirosa ou não.

José de Arruda Penteado, no manual pedagógico intitulado Didática e prática de ensino, publicado em 1979, trata da importância de a educação formar o caráter moral e ético dos alunos, através da interiorização da conduta na aprendizagem, citando o suíço Jean Piaget (1896 - 1980), para quem a educação também deve cuidar do desenvolvimento de sentimentos morais (p. 2). Alexander Sutherland Neill (1883 - 1973), fundador da escola "Summerhill", conhecido por defender a liberdade das crianças na escola, é citado 
por sempre ter sido contra a "modelagem do caráter" e por defender o autogoverno das crianças: "a escola rege-se pelo autogoverno e as crianças governam. É um atrevimento produzir um certo tipo de pessoa. Ninguém deve lhes dizer o que fazer, elas devem desenvolver um caráter próprio. Foi sempre contra a imposição e modelagem do caráter." (p. 182)

No discurso trazido pelos manuais pedagógicos acerca do cuidado de si e do autogoverno, é possível identificar como a subjetividade foi objeto de atenção por parte por educadores. Como afirmou Fontoura, a partir de 1920, com a supressão da violência física utilizada como instrumento de coerção da escola, foi necessário que houvesse um refinamento nos modos de obter a disciplina na escola e maneira de instituir formas de comportamento. Segundo Ramos do Ó (2001), a história da subjetividade começa por ligar a regra da governamentalidade ao problema do cuidado de si. Ocupar-se de si. Trata-se de uma maneira de se comportar, "um imperativo que circula entre numerosas doutrinas diferentes, que impregnou os modos de viver, desenvolveu-se em processos, práticas e receitas que foram refletidas, desenvolvidas e aperfeiçoadas; constitui assim uma prática social que deu lugar a relações interindividuais, a trocas e comunicações e por vezes mesmo a instituições; originou, finalmente, um certo modo de conhecimento e a elaboração de um saber". (op. cit., p. 28) Segundo o autor, Foucault defendeu que somos herdeiros de uma moral social organizada a partir de uma mudança maior e afirma que as reflexões e os juízos éticos sobre os prazeres que ainda hoje reconhecemos teriam sido organizados nos primeiros séculos da nossa era. Nessa perspectiva, as transformações que afetaram esta prática moral não se prendem com um aumento da severidade, nem com a instituição de práticas de censura. Ao contrário, "a mudança incide muito mais no modo como o indivíduo deve constituir-se enquanto indivíduo moral. O desenvolvimento da cultura de si produziu efeito não no reforço daquilo que poderia impedir a realização do desejo, mas em certas modificações que dizem respeito aos elementos constitutivos da subjetividade moral. (...) Mas o trabalho da união consigo próprio foi-se implantando a partir do modelo da posse e nunca a partir do da submissão. É fato indesmentível que o homem contemporâneo já está bem treinado nesta crença: pertence-se 'a si', é-se 'seu'...; só se depende de si mesmo, é-se sui júris; exerce-se sobre si próprio um poder que nada limita nem ameaça; detém-se a potestas sui. As marcas de uma lógica própria de poder tendem a esbater-se, senão mesmo a desaparecer, neste processo de construção da 
identidade pessoal. O indivíduo histórico não as reconhece na relação consigo". (op. cit., p. 29) A cultura de si é implantada pelo reconhecimento de que a fraqueza e fragilidade, características da individualidade, são combatidas através de princípios universais. Afirmase a existência de uma verdade única - definida pela razão ou pela lei - que cada indivíduo deve tomar para si. Para Foucault, o ponto de chegada desta política de governo é definido pela "soberania do indivíduo sobre ele próprio". De acordo com Ramos do Ó, "para que esse desiderato seja atingido, e o indivíduo aprenda a dominar-se sem as instantes perturbações do desejo, existe todo um 'regime austero' dominado pelas 'práticas da ascese', ou melhor, pelas 'práticas de si': os 'procedimentos de provação', os 'exames de consciência', a 'avaliação de uma falta em relação às regras de conduta' são atitudes constantes e globalmente observáveis em cada um de nós". (op. cit., p. 29 - 30) Desta forma, o exercício de autocontrole, de domínio das paixões e de cuidado de si passaria pela revisão constante das representações que o indivíduo traz consigo ao longo de sua história, daí também a importância dos exemplos, para examinar e circunscrever as suas ações, governando e censurando a si próprio. 


\section{Capítulo 4}

\section{MORALIZAÇÃo E RELIGIÃO: ENTRE A LAICIDADE PROCLAMADA E A PERMANÊNCIA DA VELHA ORDEM}

“O dualismo fundamental entre o homem do mundo e o homem de Deus continua através
dos séculos até à nossa idade, reduzida a virtude a um investimento na cidade do céu”. (Anísio Teixeira, 1958, p. 11)

A história da laicidade no ensino público brasileiro, ao menos no âmbito legal, começa no período republicano, tal como é evidenciada pela Constituição de 1891, vigente até 1934, que declarava que seria "leigo o ensino ministrado nos estabelecimentos públicos”. Contudo, a Constituição de 1934 já dizia que o ensino religioso seria de frequiência facultativa e "ministrado de acordo com os princípios da confissão religiosa do aluno manifestada pelos pais ou responsáveis e constituirá matéria dos horários nas escolas públicas primárias, secundárias, profissionais e normais". Com algumas modificações na prescrição, o ensino religioso também aparece na Constituição de 1937, onde é dito que ele poderá ser ministrado nas escolas primárias, normais e secundárias, no entanto, ele não poderá "constituir objeto de obrigação dos mestres ou professores, nem de frequiência compulsória por parte dos alunos". A ausência do ensino religioso na $1^{\mathrm{a}}$ Constituição da República e a sua instituição nas Constituições de 1934 e 1937 são o resultado prático de lutas de caráter ideológico entre os católicos e o movimento renovador da educação, este que lançaria em 1932 o Manifesto dos Pioneiros da Educação Nova endereçado ao povo e ao governo, que, além do ensino laico, também reivindicava a expansão da escola pública e a igualdade de direitos dos dois sexos à educação (ANTUNHA, 1975). As lutas travadas não possuíam apenas o aspecto religioso, mas traziam também elementos políticos e econômicos. "A Igreja Católica, que até então praticamente monopolizava, no Brasil, o ensino médio, estava, desde a proclamação da República, agastada com a laicidade do ensino, instituída pela $1^{\text {a }}$ Constituição Republicana. Agora, em face do alcance do movimento renovador e em face, principalmente, das reivindicações que este fazia em torno da necessidade de se implantar efetivamente o ensino público, de âmbito nacional obrigatório e gratuito, ela se via ameaçada de perder aquele quase monopólio" 
(ROMANELLI, 2007, p. 143) Se, na ordem social oligárquico-aristocrática as elites pagavam à Igreja pela educação dos seus filhos, sendo desnecessária a expansão do ensino público e gratuito, com a ascensão da burguesia a situação passou a ser delineada de uma outra forma, com a classe média reivindicando o direito ao ensino médio, e as camadas populares, o ensino primário, públicos e gratuitos. A campanha em torno da escola pública, na época, tinha por objetivo defender o direito de todos à educação. Em uma sociedade de classes ele só poderia ser garantido se o Estado assegurasse o mínimo de educação compatível com o nível de desenvolvimento econômico até então alcançado no país, razão pela qual o ensino deveria ser público e gratuito. Em uma sociedade heterogênea e, ministrado pelo Estado, o ensino deveria ser laico, para garantir o respeito à personalidade e à confissão religiosa dos alunos, evitando que a escola servisse de instrumento de doutrinação religiosa. Os reformadores entendiam que as diferenças entre homens e mulheres que pudessem existir, quanto à ação pedagógica, só poderiam ser fruto das diferenças naturais entre os indivíduos, psicológicas e segundo os interesses e as aptidões de cada um. Segundo as descobertas da ciência, elas não partiam da diferença entre os sexos. Contudo, essa questão era entendida de outra forma pelos católicos: “confundiam eles uma questão essencialmente pedagógica com questão de ordem moral baseadas, evidentemente, em princípios sedimentados em hábitos de educação religiosa. (...) O perigo representado pela escola pública e gratuita (...) consistia sobretudo no risco de extensão de educação escolarizada a todas as camadas, com evidente ameaça aos privilégios até então assegurados às elites. Insurgindo-se contra as reivindicações do movimento renovador, a Igreja Católica tomou o partido da velha ordem e, com isso, da educação tradicional." (op. cit., p. 144) Além da questão política e econômica que representava escolarizar as camadas mais pobres da população, o que estava em jogo era também a questão moral. Tomando partido da velha ordem e da escola tradicional, a Igreja colocava-se também contra uma nova maneira de formação que chegava ao Brasil pelas mãos dos partidários do movimento reformador, isto é, a Escola Nova. O ensino misto defendido pelos escolanovistas atacava uma prática escolar conservada pela Igreja católica desde os primórdios da escolarização na Europa, no século XVI: a separação do ensino ministrado aos homens e às mulheres. Ao contrário do que é proposto no âmbito de uma moral laica acerca do ensino misto, onde é defendido que meninos e meninas devem conviver para que adquiram autocontrole, domínio de força física e moral, característica que também é endossada pelo discurso da Escola Nova, na perspectiva religiosa a 
convivência entre os sexos representaria um perigo que trazia ares de promiscuidade e que, para o "bem de todos", deveria ser evitado. A propósito desta questão, publicado na RBEP em 1956, o relatório ${ }^{202}$ apresentado na Conferência das Escolas para a Compreensão Internacional, em colaboração com a UNESCO, dizia que "quando o colégio não é misto, o amplo desenvolvimento social dos alunos pode ser impedido. É preciso permitir aos estudantes a maior liberdade na determinação das normas de comportamento". (p. 169)

Mesmo após a Proclamação da República, em 1889, que, influenciada também pelos ideais positivistas pensava que a "nação" seria constituída sobre os pilares da educação e da ciência, não cabendo à religião um espaço nessa nova ordem, o que é possível observar no caso brasileiro é que essa separação, diferentemente do caso francês, não aconteceu, ao menos não da forma como havia sido proclamada. Bastante ilustrativa, a propósito da importância da religião para conformar moralmente as pessoas, é a afirmação feita por Anísio Teixeira" ${ }^{203}$, em artigo publicado na RBEP em 1958, na qual dizia que "a religião, em todos os tempos" é a "expressão mais alta do controle do comportamento humano" (p. 13). A disputa levada a cabo pelos católicos e pelos pioneiros passou pelas Constituições, pelas Leis Orgânicas e chegou à Lei de Diretrizes e Bases n⿳0 4.024, de 1961, onde venceu a "tese da liberdade de ensino", da defesa da escola oficial e da promoção dela em larga

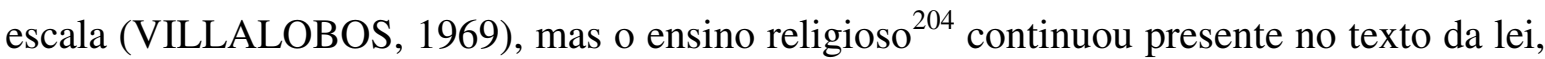
mesmo devendo ser ministrado em caráter facultativo. Se, no título I, em seu artigo $1^{\circ}$, é dito que "a educação nacional, inspirada nos princípios de liberdade e nos ideais de solidariedade humana, tem por fim: (...) b) o respeito à dignidade e às liberdades fundamentais do homem; (...) g) a condenação a qualquer tratamento desigual por motivo de convicção filosófica, política ou religiosa, bem como a quaisquer preconceitos de classe ou de raça.", o título XIII, no artigo 97, afirma que "o ensino religioso constitui disciplina

\footnotetext{
202 "A formação de professores" Trata-se do relatório apresentado na Conferência das Escolas para a Compreensão Internacional, em colaboração com a UNESCO, em 1955. RBEP, nº 64, out./dez. 1956, p. 141 -179 .

${ }^{203}$ TEIXEIRA, Anísio. "Variações sobre o tema da liberdade humana" RBEP, n 69, jan./mar. 1958, p. 3 18.

${ }^{204}$ CAMPOS, Paulo de Almeida. "Seminário regional sobre planos e programas da escola primária", RBEP, no 64, out./dez. 1956, p. 73 - 93. Trata-se do "Informe Final" do "Seminário regional sobre planos e programas da escola primária", promovido em maio, no Peru, pela UNESCO e pela OEA, visando ao estudo dos problemas relativos à generalização da educação primária gratuita e obrigatória na América Latina. $\mathrm{O}$ seminário abordou o tema do ensino religioso, considerando que esse assunto deve ser tratado por cada país em particular.
} 
dos horários das escolas oficiais, é de matrícula facultativa, e será ministrado sem ônus para os poderes públicos, de acôrdo com a confissão religiosa do aluno, manifestada por êle, se fôr capaz, ou pelo seu representante legal ou responsável." Para preservar a liberdade de ensino e atender à maioria, prevaleceu a vontade geral de pessoas influentes, padres e instituições. Para João Eduardo Rodrigues Villalobos (1969), que analisou o debate em torno do Projeto de Lei de Diretrizes e Bases da Educação Nacional, a propósito do resultado do debate e da promulgação da lei, ele afirmou: "em nome da democratização do ensino e do desenvolvimento nacional, da maior eficiência e das franquias democráticas no interior delas, condições que só a escola pública estaria em condições de criar, a tese da liberdade de ensino, na forma como foi entendida pelo programa, e as consequências dela derivadas, foram denunciadas como instrumentos postos a serviço da manutenção dos quadros tradicionais da sociedade brasileira, e, portanto, do conservadorismo e dos usufrutuários das injustiças sociais" (op. cit., 150).

No Brasil, as cores da laicidade e da religião se misturam no quadro da educação nacional ao longo do século XX, abrangendo o período que compreende a expansão do ensino, investigado pela presente pesquisa. Apesar de muitos terem lutado em defesa da laicidade, porque "a necessidade de colocar 'o ambiente escolar acima das seitas, disputas religiosas, de dogmatismo' e de excluir do mesmo 'qualquer influência perturbadora à personalidade do educando', impõe-se que seja leigo o ensino, na escola pública." (ROMANELLI, 2007, p. 147) Para se compreender as práticas de moralização nas condições históricas nas quais se produziram é preciso que esse aspecto seja levado em conta: lidamos com uma moral que em muitos momentos é proclamada como laica, mas que na prática segue a velha ordem e é delineada por práticas e preceitos religiosos, como foi possível perceber ao longo da realização deste estudo. De acordo com as Prescrições sobre currículos e programas de Educação Moral e Cívica nos três níveis de ensino (Art. $4^{\circ}$ do Decreto-Lei 869/69), a moral vincula-se a "princípios permanentes e originários de Deus" (p. 13) e é objetivo do programa básico do ensino primário "levar à compreensão do respeito a Deus e do amor à Família; fazer compreender a necessidade da Religião, para a aproximação da criatura ao Criador e para formar as bases da Moral”. (p. 19) No texto legal, fica explícita a necessidade de vincular a Moral à Religião, mostrando ao mesmo tempo que as instituições como a Família, a Religião, a Justiça, as Forças Armadas e a Pátria são o alicerce da nacionalidade. Os "deveres do ser humano para com Deus e o 
próximo, a necessidade da Religião para situar o homem no Universo e para o estabelecimento de uma escala correta de valores, as tradições religiosas da Nação brasileira, na herança dos três grupos étnicos. Formação do caráter, estabelecimento de princípios e fortalecimento da vontade. Civismo como caráter. Família como instituição: amor e renúncia. Ordem e higiene" (p. 24) deveriam fazer parte do currículo oficial. Deus, ética e moral aparecem associados e justificam a necessidade da religião na "dignificação do homem" e para as "bases da moral". (p. 39) Mesmo tendo sido promulgado no governo militar, o decreto-lei afirma que é necessidade da democracia alicerçar-se em valores espirituais e morais, para o "uso da liberdade responsável". (p. 38) Durante o exame das fontes consultadas, foi possível perceber, ao longo de todo o período investigado que os valores cristãos, enquanto importantes para a promoção da moralização, continuaram a ser utilizados pela escola mesmo depois da sua pretendida laicidade, seja pelo discurso cívico, seja pelo discurso psicológico. A prática da caridade presente no discurso religioso, por exemplo, enquanto elemento fundamental para a configuração de dispositivos políticos, poderia ser transformada em solidariedade no discurso cívico e em altruísmo no discurso psicológico, no entanto, o seu sentido era mantido.

Desta forma, ao examinar os manuais de didática e metodologia do ensino e os periódicos educacionais, é possível observar que as idéias de Comenius com relação à religião exerceram uma maior influência sobre os autores brasileiros do que aquelas relativas à laicidade trazidas pelos pioneiros do movimento escolanovista, por exemplo. Em contrapartida, a noção de autogoverno divulgada por tal movimento ressoou nos discursos pedagógicos e nas práticas educativas até o final dos anos de 1970. Ou então, nesse sentido, quando aqueles que influenciaram os autores do manifesto são citados, é comum que seja para reforçar uma idéia que vai ao encontro do amor ou do temor à Deus, implícitos na formação religiosa. Este é o caso, por exemplo do livro Fundamentos da Educação, de Afro do Amaral Fontoura, reeditado em 1954, onde é dito que a educação deve se ocupar do homem como um todo, inclusive como ser moral, fazendo com que o aluno desenvolva atitudes morais perante si e a sociedade. O autor cita Claparède a propósito da escola renovada, afirmando que a educação deve ser integral, formar a personalidade nos mais variados aspectos, inclusive moral e religioso. Além disso, caberia ao ensino de geografia a tarefa de desenvolver "valores espirituais". De outra forma, o livro Introdução ao Estudo da Escola Nova, de Manuel Bergström Lourenço Filho, 
reeditado em 1965, reforça a idéia de que a educação escolar precisa desenvolver os "caracteres religiosos-morais" nas crianças. Em outro livro, Didática Geral, que em 1965 estava na $8^{a}$ edição, Afro do Amaral Fontoura é enfático ao afirmar que "não é possível educar sem Deus. Educar é espiritualizar, não é apenas treinar para fazer cousas.” (p. 31) e também: "toda criatura humana, mercê de Deus, nasce com a educabilidade. Com a capacidade inata de se desenvolver, de crescer física, intelectual e moralmente. (p. 163) Neste livro, Fontoura, além de discorrer sobre a importância da religião, cita a religião católica em especial: "cada católico isoladamente não tem força, reunidos na Igreja passam a constituir uma poderosa expressão social e moral". (p. 121) e também "é através dos valores espirituais que o homem se sente, realmente, uma criatura de Deus." (p. 126) Para reforçar a idéia de que é preciso cultivar a religião na escola, Fontoura também transcreveu uma citação do pedagogo suíço Pestalozzi (1746 - 1827) que sempre se considerou um cristão, apesar de ter recebido orientação protestante, e nunca ter defendido uma religião específica, que diz o seguinte: "educação sem moral e religião é um erro. A fé em Deus é a fonte de toda sabedoria. O homem sem Deus e caridade não é homem, é um bárbaro". (p. 199) Observa-se que a noção de caridade é cristã e, ao ser empregada, ela desempenha um papel importante na moralização dos comportamentos, assim como o faz o conceito de fraternidade. Segundo Fernando Tude de Souza ${ }^{205}$, a fraternidade deve "abalar todos os interesses egoísticos". A fraternidade "significa mais que assistência material: significa não apenas vontade de auxiliar os necessitados, mas de atacar as causas da miséria e do sofrimento.” (p. 215) O tema da caridade ${ }^{206}$ abordado na escola é, por excelência, aquele no qual o ensino moral deve provar a sua especificidade. $\mathrm{O}$ seu tratamento sublinha uma reapropriação, pela escola laica, dos antigos valores morais. A própria educação é vista, por alguns autores, como um ato de caridade. O professor Walter Augusto Francini ${ }^{207}$, por exemplo, em artigo publicado na RP em 1961, dizia que a pobreza ainda impedia muita gente de freqüentar a escola primária, por não poder custear o material escolar, o uniforme, etc. A escola primária seria a mais conveniente ao povo porque era nesta instituição que se

\footnotetext{
${ }^{205}$ SOUZA, Fernando Tude de. "A crise dos valores morais e os educadores" (artigo inicialmente publicado em $O$ Jornal, Rio), RBEP, nº 56, out./dez. 1954, p. 212 - 215.

206 “Declaração do Concílio Ecumênico sobre Educação Cristã”, RBEP, no 100, out./dez. 1965, p. 387 - 395. A declaração afirma que a escola deve promover a vida cultural, cívica e religiosa; deverá também ministrar educação moral e religiosa e trabalhar o tema "caridade" com os alunos.
}

${ }^{207}$ FRANCINI, Walter Augusto. “Uma sugestão”, RP, Mai./Jun., 1961, p. 21. 
realizava a alfabetização. As caixas escolares haviam sido criadas para suprir tais carências materiais. O autor sugeria: "os professores devem estimular as matrículas no grupo, e também as dos adultos nos cursos noturnos. Tratar-se-ia de ótima ajuda no combate ao analfabetismo e, ao mesmo tempo, de elevada forma de caridade - a caridade que beneficia ao espírito" (p. 21).

Abordada nos manuais pedagógicos franceses, por exemplo, após os capítulos sobre os "deveres individuais" que devem aperfeiçoar a alma e o corpo, a caridade toma lugar em um quadro de estudos dos “deveres sociais". Virtude cristã por excelência, ela é reformulada pelos pedagogos republicanos como sendo "irmã da justiça e mãe da fraternidade". Em razão do seu caráter facultativo, não submetido às sanções da lei, o exercício desta virtude fica difícil. Este é o ponto da educação moral tal como eles a concebem: se a justiça faz respeitar a igualdade estabelecida pela lei, a caridade tende a compensar, pela dedicação pessoal, as desigualdades sociais e constrói uma obra de fraternidade (MERCIER, 2005). Fontoura, para quem "a maior parte das Escolas Novas tem uma atitude religiosa não sectária, como tolerância, que visa o desenvolvimento espiritual do homem" (p. 132), complementa o quadro das referências religiosas citando Dom Bosco, santo considerado apóstolo dos jovens, e referenciado pelo autor como "precursor da Escola Nova" (p. 126) por defender a "educação da razão prática". Outro autor que apresenta referências religiosas ao tratar de questões morais é Imideo Giuseppe Nérici, no livro Ensino renovado e fundamental, reeditado em 1975. Ele enfatiza ao longo do livro que é papel da educação formar o cidadão participante e, entre os itens enunciados pelo autor para a conquista de tal objetivo está a "reverência a Deus". Entre os conteúdos que deverão ser ministrados no âmbito da disciplina "educação moral e cívica" está presente também a religião. Quem também traz a questão religiosa para o interior de seu livro é José de Arruda Penteado, em Didática e prática de ensino, publicado em 1979. Neste caso, o tema é trazido através de Comenius, para quem é necessário "ensinar os bons costumes e a piedade. Fiel à moral cristã, não concebe a piedade e a virtude como fins isolados. Todos os homens são chamados à moralidade, à sabedoria, à religião" (p. 14). 


\subsection{O PERIGO DOS MEIOS DE COMUNICAÇÃO: PARA “NÃO DESPERTAR UMA CURIOSIDADE PREMATURA E MALSÃ"}

Em 1970, o então ministro da justiça do governo militar, Alfredo Buzaid (1914 1991), escreveu um livro intitulado Em defesa da moral e dos bons costumes, no qual ele buscou justificar a criação do artigo 153, parágrafo 8, da Constituição Brasileira de 1967, que "estabeleceu como regra a liberdade de pensamento e como exceção a intolerabilidade de publicações contrárias à moral e aos bons costumes". Neste livro, ele pretende explicar o sentido da censura nos meios de comunicação, no rádio, na televisão e nas publicações que circulavam no país. Tais publicações deveriam ser evitadas por estimular a liberdade e insinuar o amor livre, ameaçando destruir os valores morais da sociedade brasileira. $\mathrm{O}$ desenvolvimento das mídias no país parecia de fato preocupar aqueles que escreviam sobre educação no período. A questão é que o rádio, a televisão e as revistas atraíam a atenção das crianças e dos jovens e isso era motivo de preocupação para os educadores da época que ora posicionavam-se contra, ora a favor destes meios de comunicação. Já em 1964, o parecer $^{208} \mathbf{n}^{\mathbf{0}} \mathbf{1 3 6 / 6 4}$, do "Conselho Federal de Educação", afirmava que "(...) a formação moral e cívica não fica isenta da influência de certos órgãos formadores de opinião pública, como rádio, tevê e cinema. Nem da cooperação da família e da comunidade em geral.” (p. 137) Acerca dos "Espetáculos para menores" 209 , o parecer dizia o seguinte: "os espetáculos devem constituir para o menor, além de uma sadia distração, um poderoso meio educativo, concorrendo para a formação de sua personalidade, pela preservação de suas virtudes morais e cívicas. Devem ser examinados aspectos relacionados à malícia, vulgaridade e impropriedade, natureza imoral ou anti-social dos tipos apresentados (prostitutas, viciados, etc.). Não despertar uma curiosidade prematura e malsã. Não ridicularizar as religiões e nem desencorajar o amor à Pátria, ao povo brasileiro, às instituições e à justiça. Não podem atentar contra a família. Entre os 14 e os 18 anos, os adolescentes passam por uma crise moral e religiosa. Mostrar o triunfo da verdade e da honestidade e atos de heroísmo. Os espetáculos deverão sempre conter elementos de caráter educativo e moral. Mostrar o valor

\footnotetext{
208 "Conselho Federal de Educação" - seleção de pareceres aprovados durante o semestre - "Educação moral e cívica" - Parecer no 136/64, C.E.P. e M., aprov. em 5-6-1964 RBEP, nº5 jul./set. 1964 p. 116 - 139.

209 "Conselho Federal de Educação" - seleção de pareceres aprovados durante o semestre - "Educação moral e cívica" - Parecer no 136/64, C.E.P. e M., aprov. em 5-6-1964 "Espetáculos para menores: critérios atualizados" RBEP, n95 jul./set. 1964 p. $154-164$.
} 
do trabalho e encorajar sentimentos de abnegação e altruísmo." (p. 154 - grifos meus) A questão expressa no parecer que chamava a atenção para a crise moral e religiosa pela qual os adolescentes passam nesta fase da vida já era motivo de preocupação para o professor Rosalvo Florentino $^{210}$, em artigo publicado na RP em 1960. Para ele, na adolescência os jovens "jamais ouvem o nome de Deus" e convivem em um meio nocivo à sua formação moral: "acrescente-se a isto o cinema, o teatro e uma literatura malsã que dissolve em desilusões, descrenças, ceticismo e desânimos, o espírito da juventude e, além disso, o fatal engodo em que se colhe a mulher, fazendo-a desertar do lar doméstico." (p. 25) Neste mesmo ano, a professora Cinéa Vieira $\operatorname{Ramos}^{211}$ publicou um artigo na Revista do Professor no qual chamava a atenção pelos danos causados à formação moral das famílias pelas informações divulgadas nos meios de comunicação, que faziam com que as crianças, precocemente, soubessem de assuntos que seriam impróprios para a sua idade. O professor Faria Netto ${ }^{212}$, em artigo publicado na RP em 1960, dizia o seguinte: "a escola atual quase nada pode fazer pelo seu exíguo tempo, e infelizmente, o ambiente dispersivo em educação, inadequado ao civismo, com suas histórias de fantasias, com certos programas de televisão, os espetáculos cinematográficos não determinam os maus elementos sociais do amanhã?..." (p. 28) Determinantes na criação dos "maus elementos", os meios de comunicação eram alvo de inúmeras críticas. A televisão e o rádio, principalmente, talvez por consistirem em fontes de informação, de lazer, de sociabilidade e de cultura, não apenas individuais, mas também coletivos, estimulavam paixões e por isso representavam um perigo à moralização dos indivíduos.

Em 1971, o decreto ${ }^{213} \mathbf{n}^{\mathbf{0}} \mathbf{6 8 0 6 5}$, de 14 de janeiro, que dispõe sobre a inclusão da Educação Moral e Cívica como disciplina obrigatória nas escolas de todos os graus e modalidades dos sistemas de ensino no país, afirmava que os órgãos formadores de opinião e difusão cultural, rádio, televisão, jornais, revistas e clubes deveriam cooperar com os objetivos da disciplina, tais como: contribuir para a "formação do caráter do brasileiro e ao

\footnotetext{
${ }^{210}$ FLORENTINO, Rosalvo. “Crises no mundo contemporâneo” RP, ago./set. 1960, p. 25.

${ }^{211}$ RAMOS, Cinéa Vieira. “A família, a escola e a sociedade”, RP, abr./1960, p. 4 - 5.

${ }^{212}$ FARIA NETTO, F. de. “A educação bandeirística”, RP, Out., 1960, p. 28 - 29.

${ }^{213}$ Decreto $^{\circ} 68065$ - de 14 de janeiro de 1971. Regulamenta o Decreto-lei no 869 , de 12-9-1969, que dispõe sobre a inclusão da Educação Moral e Cívica, como disciplina obrigatória, nas escolas de todos os graus e modalidades dos sistemas de ensino no País, e dá outras providências. RBEP, nº 122 abr./jun. 1971 p. 365 375.
} 
seu preparo para o perfeito exercício da cidadania democrática, com o fortalecimento dos valores morais da nacionalidade" (art. $2^{\circ}$ ). De acordo com o decreto, a disciplina tinha como finalidade: “a) a defesa do princípio democrático, através da preservação do espírito religioso, da dignidade da pessoa humana e do amor à liberdade com responsabilidade, sob a inspiração de Deus; b) preservação dos valores espirituais e éticos da nacionalidade. Fortalecimento da unidade nacional culto à Pátria, instituições, aprimoramento do caráter, dedicação à família e à comunidade, patriotismo." (art. 3º Caso os meios de comunicação não contribuíssem com os ideais partilhados pela disciplina, a "Comissão Nacional de Moral e Civismo", composta por nove membros nomeados pelo presidente da República, deveria articular-se com os órgãos da censura e impedir a veiculação de informações contrárias à “ordem” vigente.

Afinal, quais seriam os efeitos que os meios de comunicação poderiam ter na formação dos indivíduos? Para Artur Távola ${ }^{214}$ (pseudônimo de Paulo Alberto Monteiro de Barros, antigo redator-chefe da RBEP), eles poderiam modelar parte do comportamento das crianças. O autor fazia uma analogia entre o poder de massificação das mídias, as religiões e os "nacionalismos". Para ele, todas as formas de massificação existentes ao longo da história acabaram, por seu desejo de imposição do poder, gerando os "anticorpos" que as removeram lenta ou rapidamente: "toda e qualquer forma de exercício de poder social ou psicológico montou formas de massificação, verdadeiros edifícios de comunicação destinados a manter e a preservar os seus valores, as suas idéias, as suas verdades parciais em nome das quais elas se apresentavam como detentoras da Verdade, do Bem, da Justiça. Montou, monta e montará.” (p. 255) Contudo, Távola acredita que a comunicação eletrônica, por mais manipulada que seja, tem por definição uma estrutura mais aberta e transformadora que as "instituições tradicionais de massificação": a escola, a família, a religião, o grupo comunitário. Posição contrária apresentou Ethel Bauzer Medeiros $^{215}$, pesquisadora da Fundação Getúlio Vargas, que acreditava que as crianças e os jovens eram "presas fáceis" diante das diversões comercializadas e do consumismo trazido

\footnotetext{
${ }^{214}$ TÁVOLA, Artur. (pseudônimo de Paulo Alberto Monteiro de Barros, antigo redator-chefe da revista) "A criança e a comunicação no mundo atual", RBEP, nº 143, jan./abr. 1979, p. 251 - 258.

${ }^{215}$ MEDEIROS, Ethel Bauzer. "Brincar: uma das ocupações mais sérias da infância", RBEP, no 143 , jan./abr. 1979, p. $259-268$.
} 
pela publicidade: "bombardeados" por estímulos visuais e auditivos, eles aderiam à última moda em roupas, penteados e brinquedos porque não tinham liberdade de escolha.

Buzaid afirmava que o Estado intervinha no domínio da moral em nome dos princípios cristãos: "diferente da Rússia marxista, da Alemanha hitlerista e da Itália fascista, onde tudo era o Estado e nada se concebia fora do Estado, onde o Estado tinha formação hegeliana em sua dupla derivação: o materialismo histórico e o idealismo dialético, as raízes filosóficas em que se assentam as duas concepções do Estado são diversas, sendo ilegítimo invocar o exemplo daqueles países para justificar as regras da moralidade que no Brasil buscam preservar a civilização cristã”. (p. 28) Em uma época considerada "revolucionária", em que o legislador tinha a consciência da "ameaça que o erotismo representa", tolerar as publicações contrárias à moral e aos bons costumes significava concorrer para a degradação da juventude e a dissolução da família. A revolução à qual o autor se refere é aquela almejada pelo comunismo e seus agentes seriam aqueles os "inimigos da Pátria" e promotores da "subversão da ordem”. A preocupação expressa por Buzaid parece ser fruto da teoria da "guerra interna", introduzida pelos militares no Brasil por influência da Revolução Cubana. De acordo com Thomas Skidmore (1988), "segundo essa teoria, a principal ameaça vinha não da invasão externa, mas dos sindicatos trabalhistas de esquerda, dos intelectuais, das organizações de trabalhadores rurais, do clero e dos estudantes e professores universitários. Todas essas categorias representavam séria ameaça para o país e por isso teriam de ser todas elas neutralizadas ou extirpadas através de ações decisivas" (op. cit., p. 22). Essa forma de pensar "anticomunista" é visível também em alguns discursos veiculados nas fontes examinadas, que atribuem à moralização das crianças e dos jovens uma tentativa de defender a nação de uma "conspiração" que extinguiria os valores e as instituições tradicionais do país. Em 1960, o professor Scyllas Steffen ${ }^{216}$, publicara um artigo na RP, no qual definia como “conturbada” a época em que vivia: “(...) vemos o desequilíbrio mental dos indivíduos nas sociedades. Há um desajustamento no modo de julgar os valores morais. Hoje tudo está nivelado. (...) O fruto desse estado de espírito, corrompido e anárquico, já se faz sentir em diversos setores, tais como a imprensa, rádio e televisão. (...) O rádio e a televisão são outros agentes que levam a milhares de lares honestos, os programas mais imorais e sórdidos. (...) agora este germe da anarquia está começando a corroer o sustentáculo de

${ }^{216}$ STEFFEN, Scyllas. “As instituições e o indivíduo”, RP, Nov., 1960, p. 8 - 9. 
toda a sociedade organizada, família, religião e ensino - é inegável que algumas providências devem ser tomadas. (...) A família sempre foi o centro das experiências humanas, casamento, lar, o futuro cidadão modela a prosperidade do Estado. (...) Não é, sem dúvida, apenas a era mecânica que motiva o colapso. Nem é também, apenas a pressão econômica. Pressão industrial. O que perverte a personalidade é a restrição do desenvolvimento social. (...) Quando aparece a colisão entre os direitos do indivíduo e os costumes da ordem social, aparece o desequilíbrio como consequiência." (p. 8 - grifos meus) $\mathrm{O}$ rádio $^{217}$, que poderia chegar a todos, mesmo àqueles que não tivessem acesso à escola, assim como os outros meios de comunicação que estavam em ascensão, era acusado de corromper os valores morais. No final dos anos de 1940, o rádio havia se consolidado como fenômeno cotidiano, ligado à cultura popular urbana, veiculando principalmente novelas e músicas. No início dos anos de 1950, a Rádio Nacional já havia massificado os programas de auditório, um gênero que trazia para o rádio a participação direta do povo e que consolidou o gosto popular por esse meio de comunicação, impulsionando ainda mais a paixão em torno dele. Nessa época, consagrou-se na imprensa a expressão "macacas de auditório", em um tom preconceituoso, para qualificar o público radiofônico das mulheres mais pobres que se manifestavam freneticamente diante de seus ídolos. Em oposição às críticas daqueles que almejavam um rádio "educativo" que transmitisse tanto a cultura originária da Europa quanto valores morais tradicionais, as paixões populares, o gosto musical mais simples e a busca por lazer por grande parte da população venceram, também de acordo com os interesses dos empresários que investiram neste veículo (CASTRO, 2005).

Para educadores como Steffen, a solução para impedir que o caos fosse instalado na sociedade seria promover o retorno, nas escolas, à disciplina tradicional que havia nos grupos escolares, de modo a desenvolver nas crianças a obediência às normas sociais. Além disso, também seria preciso cultuar a tradição e o patriotismo, afinal, dizia o autor, "somos funcionários de um Estado que é o ideal de uma Nação" (p. 8). No entanto, as escolas em 1960 já não eram mais as mesmas da virada do século XIX para o século XX, época em que foram concebidos e criados os grupos escolares. A luta em favor da liberdade sexual e o combate às leis que reprimiam as publicações pornográficas

\footnotetext{
${ }^{217}$ Acerca do rádio no Brasil, ver o trabalho de Renato de Sousa Porto Gilioli: Educação e cultura no rádio brasileiro: concepções de radioescola em Roquette-Pinto, tese de doutorado, FEUSP, 2008.
} 
obedeceriam então a um plano de ação revolucionária que corresponderia aos propósitos de agitação "marxista-leninista". Em nome da segurança nacional, a censura era justificada por proteger a instituição da família, preservando-lhe os valores éticos e assegurando a "formação sadia e digna da mocidade". As idéias "dissolventes" que representavam tanto perigo para a sociedade brasileira seriam trazidas pelos comunistas e divulgadas nos meios de comunicação, inclusive através de mensagens "subliminares". O cristianismo era então evocado na lei por proteger a moral e auxiliar o governo na defesa da instituição familiar já que "foi a legislação romana cristã, por sua base ética, que deu larga aplicação dos princípios morais no campo sexual mediante uma série de providências, que objetivaram não só reprimir penalmente, mas ainda a prevenir tudo que pudesse ser atentado ao pudor ou tivesse caráter de obscenidade, evitando por tal modo o incitamento a pecar. A partir de Constantino a moral sexual cristã se eleva à categoria de norma jurídica” (BUZAID, 1970). A legislação então passou a entender por "bons costumes" as normas de moralidade pública. Desta forma, os "bons costumes" seriam os atos praticados por "pessoas honestas, corretas, de boa-fé". Contudo, se a justificativa para o combate ao comunismo seria a preservação, com o auxílio da Igreja Católica, da integridade da família brasileira e da sua moralidade tradicional que estariam ameaçadas pela difusão de idéias revolucionárias que pregavam o amor livre, havia também um outro elemento que ameaçava a manutenção do governo, mas que não estava tão enfatizado no discurso oficial: o objetivo maior do comunismo é a supressão do Estado, de forma que os homens deveriam trabalhar para a sociedade sem a necessidade de normas jurídicas que regulassem a sua conduta. Em 1958, Anísio Teixeira $^{218}$ publicou um artigo na RBEP no qual discutia o tema da liberdade humana. Ao tratar do comunismo, ele afirmou: "mas o comunismo, sempre que recusa crer na possibilidade do seu triunfo pacífico, pela persuasão e pela razão, deposita sua fé nos meios de doutrinação e de força, faz-se ideológico e não utópico, no sentido em que estamos procurando caracterizar esses termos. O comunismo somente seria aceitável se aceitasse os métodos da razão e da persuasão socialista." (p. 14) O professor universitário americano George S. Counts ${ }^{219}$, ao escrever sobre a educação nos Estados Unidos, também

\footnotetext{
${ }^{218}$ TEIXEIRA, Anísio. "Variações sobre o tema da liberdade humana" RBEP, no 69, jan./mar. 1958, p. 3 18.

${ }^{219}$ COUNTS, George S. "A educação dos Estados Unidos através do espelho soviético" RBEP, No 50, abr./jun. 1953, p. $44-53$.
} 
alertava sobre o "perigo da agressão comunista" (p. 44). Além disso, as idéias comunistas também ameaçavam a aristocracia rural, que dominava o Brasil. Contrários à concentração de poder, ao patriotismo e ateus, os comunistas eram considerados grandes inimigos da ditadura. Combinada com a censura, a Educação Moral e Cívica seria uma grande aliada na propagação da idéias de "ordem e progresso" e à perpetuação de práticas necessárias à manutenção do governo militar. O problema apresentado pelos meios de comunicação à moralização dos indivíduos estava na livre circulação das idéias, porque pelas idéias as pessoas também poderiam ser induzidas a aderir a algo, daí o perigo representado pela mídia e pelo comunismo. Além disso, as famílias consideradas "desestruturadas" e os pobres, pouco dotados de pudores e de autocontrole, poderiam ceder mais facilmente aos desejos e aos vícios, colocando em risco a segurança alcançada pelo estabelecimento das normas de convivência e ameaçando um retorno à barbárie. Os valores sociais e morais, para que prevalecessem e fossem colocados em prática, sendo corporificados através dos comportamentos dos indivíduos, precisariam ser constantemente reafirmados e jamais questionados. Então a necessidade de controlar bem o acesso às informações para aqueles que ainda não tivessem sido suficientemente moralizados e que, desta forma, poderiam aderir a idéias e a um modo de vida não desejáveis, não representassem um perigo para si e para os outros.

\subsection{O PROFESSOR SACERDOTE: AQUELE “QUE ABRE OU FECHA AS PORTAS DO CÉU”}

Embalada pelo discurso religioso, a moralização dos indivíduos na escola pode ser notada inicialmente pela palavra e depois pela forma, isto é, tanto nas prescrições quanto nas práticas que permeiam a instituição escolar é possível identificar elementos que visam a conformar moralmente as pessoas. A noção de sacerdócio, aplicada à docência, consiste num primeiro indício da questão. Sabe-se que a docência teve origem nas congregações religiosas e que, apesar do processo de profissionalização docente estar relacionado à constituição do Estado-nação, a sua origem deixou marcas na profissão que são visíveis até os dias atuais. A docência, que teve sua gênese nas congregações religiosas, durante seu processo de profissionalização passou por algumas fases que a caracterizaram. Inicialmente, há a obrigatoriedade, por parte do Estado, da licença para exercer a atividade. Outra 
característica é o exercício da profissão em tempo integral, ou seja, pessoas que não lecionavam como atividade secundária, mas sim como ocupação principal. O surgimento das instituições de formação de professores e as associações docentes completam o quadro que configura tal processo. As escolas normais, mais do que formar professores, produzem a profissão docente (NÓVOA, 1995). No Brasil, estas instituições começaram a ser construídas na segunda metade do século XIX. De acordo com António Nóvoa (1996), “as escolas normais constituem o recinto adequado para disciplinar os docentes, transformados em agentes do projeto social e político da modernidade: os discursos produzidos nesta instituição edificam um modelo de professor que mistura as 'antigas' referências religiosas com o 'novo' papel de servidores do Estado”. (op. cit., p. 3) Os dispositivos de controle dos docentes, em especial das mulheres, não atuavam apenas sobre os aspectos profissionais, mas também eram estendidos às dimensões privadas. $\mathrm{O}$ corpo e a vida das professoras primárias tornaram-se objeto de controle e de vigilância. De acordo com Nóvoa, este modelo difundiu-se durante várias décadas, assumindo formas mais burocráticas e técnicas de controle. A forma como o comportamento moral das mulheres era controlado evidencia que as noções de pureza e de moralidade foram tornando-se símbolos do trabalho docente feminino. Pelo exame das fontes consultadas, é possível perceber que era desejável que ingressassem no magistério pessoas que pudessem corresponder ao perfil do sacerdócio. $\mathrm{O}$ artigo do professor Jomar Monteiro ${ }^{220}$, publicado na RP em 1959, é bastante ilustrativo a propósito da questão. Ele defendia que era "preciso exame para colocar no magistério indivíduos ajustados, com virtualidades inatas para a nobre missão, transformando-a no sacerdócio dos bons tempos de outrora.” (p. 25) Segundo Carlos Mascaro (1956), o magistério primário seria um tipo de atividade que teria muito em comum com o sacerdócio e com a vida militar: "o padre, o pastor, e o soldado, se desejam realmente desempenhar a sua missão, devem contentar-se com as limitações que a carreira impõe. Se desejam ser isso e mais alguma coisa, ou se pretendem ser o que são enquanto não puderem ser outra coisa, cedo nada serão. O mesmo acontece com o professor.” (op. cit., p. 39)

Se aproximação entre a figura dos professores e dos padres pode transmitir uma aura de respeito e de caráter exemplar, ela também pode dar margem, àqueles que estão sob seus cuidados, de "baixarem a guarda" e demolirem a fronteira da sua intimidade, fazendo com

\footnotetext{
${ }^{220}$ MONTEIRO, Jomar. "Ingresso ao magistério primário", RP, dez./1959, p. 25.
} 
que o outro, no caso, o professor, possa ter acesso ao mais íntimo de cada um, e dessa forma possa conquistar, mais do que a confiança e os respeito dos seus alunos, o acesso ao seu pensamento, às suas confidências e possa controlá-las. Práticas como a confissão, exercidas pelos padres nas igrejas, são exercidas pelos professores nas escolas, quando estes levam as crianças a falarem de si, interrogando-as sobre a sua conduta e elas devem sempre dizer "a verdade". Alguns psicanalistas consideram que tal prática, a da invasão da intimidade do outro, exerce um efeito bastante nocivo na constituição psíquica dos indivíduos, para eles: "o direito ao segredo é fundamental para o bom desenvolvimento da criança, sendo a psicose um dos preços pagos pelo indivíduo se a mãe não permitir ao filho o usufruto desse direito". (DE LA TAILLE, et al, 1992, p. 45) No âmbito escolar, dizer sempre a "verdade" adquire um caráter bastante educativo e moralizador. Isto porque tal ação pode expor a intimidade da criança, deixando-a sem defesas, e também pode demonstrar ao restante dos alunos o que ocorre àquele que desvia de alguma maneira a sua conduta. $\mathrm{O}$ ato de confessar algo, falar de si, possui dimensões religiosas e políticas, e adquire na escola o caráter "educativo" e punitivo. Punitivo em um duplo sentido, porque aquele que conta algo de sua intimidade tem a sua privacidade invadida e também porque a partir da confissão o indivíduo estará sujeito às sanções legais que a infração acarretou. Além disso, quando é pedido na escola que as crianças falem de si, especialmente em situações de conflito, a confissão relaciona-se diretamente aos valores morais como, por exemplo, o da honestidade, da verdade e da proteção aos inocentes que podem levar a culpa caso o verdadeiro culpado não confesse o que fez. Nesse sentido, fica clara o quanto a transposição de regras estabelecidas para o convívio das pessoas na sociedade como um todo são incorporadas pela instituição escolar. No entanto, na vida adulta, quando é pedido que as pessoas falem de si próprias, elas já construíram a fronteira moral da intimidade, ou seja, a "progressiva elaboração de regras que permitem ao indivíduo decidir quem, de direito, pode ser incluído ou excluído do leque das pessoas-alvo das confissões de um delito, e em que situações." (op. cit., p. 46) Contudo, a infância representa uma fase da vida na qual ainda não foi erguida tal barreira de proteção contra a invasão alheia, e as crianças estão sujeitas a humilhações sem possuir os meios psicológicos para lidar com elas: "vale dizer que vai sofrer sem poder ver no outro, que a humilha, alguém que está agindo de forma errada, abusiva. Sua parte emocional vai se revoltar, ainda sem a revolta complementar e essencial de sua parte racional." (op. cit., p. 46) Outro aspecto a ser observado no ato de falar de si é que a confidência feita pelos alunos aos professores pode vir a transformar-se em confissão. 
O professor universitário Lauro de Oliveira Lima ${ }^{221}$, empregando a palavra sacerdote em outro sentido, afirma que a função docente tem características que a tornam imune a qualquer avaliação objetiva. Para ele, quando se manifesta qualquer fracasso na aprendizagem, a culpa é sempre do aluno, que não estudou o bastante. No entanto, toda a vida posterior do aluno depende do cerimonial escolar (aulas, cursos, provas, diplomas) do qual o professor é o "sumo sacerdote que abre ou fecha as portas do céu" (p. 186). Lima refere-se ao professor como o sacerdote que pode punir e atemorizar, fazendo isso mediante o poder de reprovar as crianças. Essa associação entre o sacerdócio e o poder de coação dos professores não foi a mais comum entre aqueles fizeram uso de tal imagem para escrever sobre a docência. Para grande parte dos autores que trataram desta questão nos periódicos educacionais, o sacerdócio esteve mais atrelado à disposição que os mestres precisariam demonstrar para a doação e o amor ao próximo. "O educador é um indivíduo de tipo básico social, posto a serviço espiritual de uma coletividade e cuja simples inclinação ou simpatia o leva a exercer influência na criança, como futuro portador de valores ilimitados, formando-se espiritualmente, na medida de sua capacidade especial, e que na atuação daquela simpatia encontre a maior satisfação. (...) o tipo social não é o de quem suporta, aceita, mas o de quem descobre maior satisfação que assim seja o seu trabalho." $\left(\mathbf{R B E P}, \mathrm{n}^{\mathbf{0}}\right.$ 107, jul/set. 1967, p. 121) A declaração anterior é de Paulo Rosas ${ }^{222}$, diretor do Instituto de Psicologia do Trabalho de Pernambuco, escrita em artigo sobre o exame psicológico de candidatas ao magistério primário. Para ele, o "gosto pelo social" deve ser corporificado no amor à criança e na satisfação de trabalhar com elas. Ao entrevistar as futuras professoras primárias, o autor constatou que, inclinadas a encarar seu trabalho com idealismo, como um sacerdócio, "é explicável que 48,5\% considerem que o trabalho ideal deve 'dar oportunidade de ajudar os outros"”. (op. cit., p. 143) Outro elemento que associa a docência ao sacerdócio é a vocação. O professor universitário Abgar Renault ${ }^{223}$, ao escrever sobre as professoras que trabalhavam nas escolas rurais, indica que tais profissionais precisem ter "um conjunto de dons pessoais que constituem a forma de ser dos destinos humanos - a

\footnotetext{
${ }^{221}$ LIMA, Lauro de Oliveira. "Instrução de ontem ou educação para amanhã" (artigo inicialmente publicado na Folha de S. Paulo), RBEP, nº 109, jan./mar. 1968, p. $185-203$.

${ }^{222}$ ROSAS, Paulo. "Exame psicológico de candidatas ao magistério primário de Maceió", RBEP, $\mathrm{n}^{\circ}$ 107, jul/set. 1967, p. $111-151$.

${ }^{223}$ RENAULT, Abgar. (publicado inicialmente no "Mensageiro Rural", Minas Gerais) "A professora rural e o cumprimento de sua missão", o texto é um discurso que foi proferido pelo paraninfo da $2^{\mathrm{a}}$ turma da Escola Normal Rural “A. S. Azevedo”, de Minas Gerais, RBEP, nº 60, out./dez. 1955, p. 235 - 243.
} 
vocação. E, pelas dificuldades que enfrenta, a professora rural deve possuí-las em mais alto grau ainda. Ela é mais importante que as outras professoras. Ela deve sacrificar-se pela sua pequena comunidade.” (p. 236) Para ele, as professoras devem ter dons pessoais, devendo ser também pacientes e sensíveis: "a professora vai devotar-se a uma missão com coragem para enfrentar todos os sacrifícios. (...) o magistério deixa de ser uma profissão ou um meio de vida para ser um modo de vida, e assume a força, a forma e o valor do mais relevante de todos os serviços públicos" (op. cit., p. 235 - grifos meus). Renault ${ }^{224}$, em artigo acerca da educação industrial, publicado na mesma revista em ano anterior, insere novamente a noção de "dom" no âmbito educacional: "a unidade corporal e espiritual da educação conseguiu estabelecer uma dicotomia deformadora: as mãos e os olhos funcionam coordenadamente para os efeitos do trabalho criador, mas desligados do resto da pessoa humana. A educação técnica deve comunicar o sentido do concreto e o sentido da exatidão. Dessa combinação origina-se um dom, uma força, que se traduz numa disciplina especial, de natureza intelectual e moral. Sua contribuição se traduz em novos hábitos, atitudes e aptidões" (p. 204). Segundo Noëlle Bisseret (1979), a noção de dom ou de aptidão natural é fruto de uma ideologia que culpabiliza o indivíduo pelos efeitos provocados pelas desigualdades sociais. De acordo com a autora “a palavra 'aptidão' é ainda um dos suportes da interpretação simbólica total que a sociedade se dá de sua ordenação e de seus próprios conflitos. Efeito de certos fenômenos sociais concretos, a ideologia segundo a qual as desigualdades sociais são apreendidas como conseqüência das diferenças naturais entre os grupos humanos é também um mediador na gênese das condutas coletivas que orientam as transformações do sistema escolar e do sistema social" (op. cit., p. 66 - 67). Revestido de uma dádiva, como o dom, ou de aparência científica, como a aptidão natural, a representação do trabalho docente foi impregnada por este discurso ideológico, que enxergava as professoras primárias como missionárias, e contribuía também para a inércia de seu habitus (PEREIRA, 2001).

Assim, segundo o discurso veiculado nas fontes consultadas, os professores incorporavam características como a coerção e o poder de julgamento, de decidir o bem e o mal, o certo e o errado acerca da conduta das pessoas, transmitindo valores religiosos que regiam o exercício do sacerdócio dos padres. A noção de dom, associada à profissão

${ }^{224}$ RENAULT, Abgar. (Boletim da CBAI, Rio) "Cultura técnica como fator de dinamização da cultura geral" Discurso proferido na Sessão de Instalação da I Mesa Redonda Brasileira de Educação Industrial, de Belo Horizonte. RBEP, n 56, out./dez. 1954, p. 203 - 207. 
docente, evidencia a representação, partilhada por muitos autores, de que o trabalho dos professores não dependia de formação, de preparo e nem de remuneração, mas carecia de vocação, de predisposição, de abnegação, de doação e de amor ao próximo. Acerca da abnegação enquanto estigma do professor, Guido de Almeida (1986), ao analisar redações produzidas pelos professores acerca do seu próprio trabalho, teceu a seguinte consideração: os textos comprovam "uma defasagem bastante nítida entre o real e o ideológico: pessoas de carne e osso, disputando acirradamente um emprego público, à mesma época em que a sua classe luta por melhores vencimentos, fazem a apologia de doação total, omitem ou até minimizam a questão salarial e pregam mesmo que o educador deve desprender-se das coisas materiais." (op. cit., p. 79) O autor referia-se ao início dos anos de 1980, período no qual a categoria profissional apresentava uma nova configuração, mais combativa e, mesmo assim, o discurso acerca do sacerdócio prevalecia.

\subsection{A PREPARAÇÃO PARA A VIDA EM COMUNIDADE E A VALORIZAÇÃO DA FAMÍLIA: “O VALOR DO POVO SE BASEIA NO VALOR DAS MÃES"}

Assim como a imagem do sacerdote e os seus predicados são apropriados pelo discurso educacional, valores como a constituição da família também são caros aos educadores, como foi possível depreender do exame realizado na literatura pedagógica. Segundo Pierre Bourdieu (1996), a família, enquanto importante instrumento de construção da realidade, "tem um papel determinante na manutenção da ordem social, na reprodução, não apenas biológica, mas social, isto é, na reprodução da estrutura do espaço social e das relações sociais. Ela é um dos lugares por excelência de acumulação do capital sob seus diferentes tipos e de sua transmissão entre as gerações: ela resguarda sua unidade pela transmissão e para a transmissão, para poder transmitir e porque ela pode transmitir. Ela é o 'sujeito' principal das estratégias de reprodução" (op. cit., p. 131). De acordo com o autor, as forças exercidas pela família - não apenas pela afinidade dos habitus, mas também pela solidariedade de interesses - impulsionam os seus membros a aceitar um ponto de vista comum, inibindo a manifestação de opiniões mais egoístas. Não por acaso ela está na gênese no discurso católico e foi apropriada por aquele enunciado pelos 
militares durante o seu governo no Brasil (1964-1985). O Decreto-Lei no 869/69, de 12/9/1969, que determina a obrigatoriedade da disciplina educação moral e cívica nos três níveis de ensino é uma evidência disso: é objetivo do programa básico do ensino primário "levar à compreensão do respeito a Deus e do amor à Família; fazer compreender a necessidade da Religião, para a aproximação da criatura ao Criador e para formar as bases da Moral" (p. 19) e também fica explícita a necessidade de vincular a moral à religião e a evidência de que a representação da família tradicional consiste num dos alicerces da nacionalidade, configurando um dispositivo político importante à medida que, segundo o próprio documento, ela é fundamentada no "amor" e na "renúncia", manejando, deste modo, a subjetividade dos indivíduos em função das demandas do Estado. Cabe lembrar ainda, mais algumas palavras de Bourdieu (1996) a propósito da família: "ela é o lugar de uma espécie de vontade transcendente que se manifesta em decisões coletivas e no qual seus membros se sentem levados a agir como partes de um corpo unido" (op. cit., p. 131). É em favor dela primeiramente que os indivíduos são levados a anular as suas paixões assim como será em favor do Estado que eles o farão conseqüentemente. Assim, a família consiste num objeto de disputa importante no campo social porque o seu controle ideológico - o manejo de suas representações e das representações partilhadas pelos seus agentes - traz poder a quem o detém.

A influência da Igreja, especialmente a católica, parece imprimir uma marca na tentativa de moralização dos indivíduos pela escola. Alguns autores sugerem que toda reforma que se pretenda, em educação, deve começar pela família. A professora Cinéa Vieira $\operatorname{Ramos}^{225}$, em artigo publicado na RP em 1960, afirma que o grupo religioso exerce grande influência na formação do educando e, em geral, toda família costuma ter uma religião e cumprir seus princípios e orientações, o que a autora considera positivo do ponto de vista educativo: "a religião vai nortear as atitudes do indivíduo, dando-lhe formação moral. Assim, todo aquele que possui formação religiosa terá sentimentos e atitudes diferentes daqueles que não possuem. São mais dóceis, mais obedientes, mais humanos. A religião é, sobretudo, uma necessidade psicológica para o indivíduo e a criança desde cedo precisa receber os ensinamentos religiosos e ser orientada à luz desses princípios, a fim de que não sobrevenham frustrações no futuro e possa atender ao objetivo supremo da vida." (p. 5) A defesa da família e da religião na formação das crianças feita por Ramos é

${ }^{225}$ RAMOS, Cinéa Vieira. "A família, a escola e a sociedade”, RP, abr./1960, p. 4 - 5. 
justificada pelo "perigo" representado pelos meios de comunicação que evoluíam a cada dia. Para ela, o cinema, a televisão, o rádio e as revistas exploravam de maneira "fantástica" os instintos do "mau homem" e atraíam os adolescentes pelas ilustrações berrantes, "arrastando-os" para o crime, a sensualidade e a corrupção.

A representação da família tradicional surge nos discursos veiculados nas fontes consultadas como instituição que irá proteger os indivíduos, funcionando também como uma autodefesa. Este é o ponto de vista de autores como o educador Fernando Tude de Souza $^{226}$, em artigo publicado na RBEP em 1954, no qual afirma que as escolas devem ter como principal função ensinar o respeito pelas instituições como a família, o que funcionaria como uma "autodefesa". (p. 215) Para Paulo de Almeida Campos ${ }^{227}$, pesquisador do INEP, em artigo publicado na RBEP em 1956, a escola deve preparar para a "vida familiar" (p. 79) A posição é partilhada por Robert J. Havighurst ${ }^{228}$, também pesquisador do INEP, em artigo publicado na RBEP em 1957. Ao afirmar que a escola pode colaborar com tarefas que ajudem na aquisição de uma consciência moral e de uma escala de valores, o autor cita a preparação para a vida em família e para as responsabilidades matrimoniais; conceitos e habilidades necessários ao exercício dos deveres cívicos. Segundo Havighurst, na sociedade democrática e industrializada, a escola é considerada um agente de melhoria da sociedade que se encontra em transformação: "a vocação, a cidadania, a saúde, o casamento feliz e o caráter moral são facetas distintas na educação de uma pessoa" (p. 142). E o autor explica que os jovens devem ser preparados para ocupar posições muito diferentes daquelas ocupadas por seus pais. Assim, a escola destinada a todos não deveria se preocupar apenas com os aspectos intelectuais, sua posição seria tão importante quanto o lar e mais importante do que a igreja no auxílio ao desenvolvimento das tarefas evolutivas dos jovens. A associação entre o lar e a escola na formação do caráter das crianças e dos jovens também é defendida pelo professor Norberto

\footnotetext{
${ }^{226}$ SOUZA, Fernando Tude de. "A crise dos valores morais e os educadores" (artigo inicialmente publicado em $O$ Jornal, Rio), RBEP, no 56, out./dez. 1954, p. $212-215$.

227 CAMPOS, Paulo de Almeida. "Seminário regional sobre planos e programas da escola primária", RBEP, n 64 , out./dez. 1956, p. 73 - 93. Trata-se do "Informe Final" do "Seminário regional sobre planos e programas da escola primária", promovido em maio, no Peru, pela UNESCO e pela OEA, visando ao estudo dos problemas relativos à generalização da educação primária gratuita e obrigatória na América Latina.

${ }^{228}$ HAVIGHURST, Robert J. "Tarefas evolutivas das crianças e dos adolescentes”, RBEP, n 67 jul./set. 1957 p. $130-143$.
} 
Souza Pinto ${ }^{229}$, em artigo publicado na RP em 1960. Para tanto, o autor citou Pestalozzi: “a educação de ambas deve dispensar à criança princípios sadios de moral e disciplina, contribuindo para a formação de bons hábitos e conduzindo a inclinações para ideais elevados e nobres. Pestalozzi diz que a educação serve para preparar a criança para cumprir seus deveres durante a vida, sendo a continuação do lar, produz suas obras em seus aspectos intelectuais, moral e cívico" (p. 5).

Se alguns artigos demonstram preocupação com o papel da escola na formação dos indivíduos, visando à valorização da vida em família, outros escrevem sobre a degradação da família enquanto instituição e sobre a sua incapacidade de prover o "desenvolvimento social e a cultura geral”230. Alberto Ferreira Giúdice ${ }^{231}$, diretor de grupo escolar, em artigo publicado na RP em 1958, afirmava que cabia à escola formar o caráter das crianças, uma vez que isso não estava sendo feito em casa como deveria. Para ele, reside na mulher a "força máxima" na educação das crianças, já que estas irão copiar-lhe todos os hábitos, atitudes, costumes, linguagem, moral, sentimentos, espírito de fraternidade: "se a criança tem uma boa mãe é quase certo que não se deve temer pelo seu futuro, pois o exemplo está ali para ser copiado pelo filho. Todavia, quando o infante tem uma mãe depravada, se não encontrar quem lhe guie os passos, fatalmente se tornará também depravado. É conseqüência lógica e depravada. Daí a sugestão de educar primeiro a mulher, principalmente aquelas que já são mães. O valor do povo se baseia no valor das mães. A esposa ou mãe é responsável pela formação do caráter dos filhos, porque sua atitude irá influir na vida do marido, chegando a trazê-lo a um bom caminho se preciso. A escola não deve descuidar da formação moral do educando.” (p. 11 - grifos meus) Em artigo publicado na RBEP em 1960, Roger $\mathrm{Gal}^{232}$, pesquisador do Instituto Pedagógico Nacional da França, por exemplo, a propósito do ensino de segundo grau, sugere que este deve acolher um conjunto de disciplinas e atender às necessidades antes ignoradas e relegadas à família: a educação moral, física, higiene, formação de caráter, etc. A situação econômica na qual viviam as famílias também preocupava os educadores e estava diretamente

\footnotetext{
${ }^{229}$ PINTO, Norberto Souza. "O lar e a escola", RP, mar./1960 p. 5 - 6

230 “A formação de professores" RBEP, no 64 out./dez. 1956, p. 141 - 179. Trata-se do relatório apresentado na Conferência das Escolas para a Compreensão Internacional, em colaboração com a UNESCO, em 1955.

${ }^{231}$ GIÚDICE, Alberto Ferreira. "Caráter”, RP, no 40, jul./1958, p. 11.

${ }^{232}$ GAL, Roger. “O ensino secundário e o mundo moderno”, RBEP, nº 78 abr./jun. 1960, p. 19 - 27.
} 
associada à conformação moral dos indivíduos. Em 1970, Maria Isaura Pereira de Queiroz $^{233}$, professora da Universidade de São Paulo, escreveu na RBEP o artigo intitulado "Infância e adolescência as favelas brasileiras", no qual expressou a seguinte preocupação: "quanto mais a favela está diferenciada por dentro, tanto mais as tensões sociais se tornam importantes, decorrendo tanto da diferença do nível de vida, quanto de diferenças no comportamento das famílias em relação às crianças. Cuidar da sua instrução, de seus bons modos, como o fazem as famílias economicamente melhor situadas, é coisa ridicularizada pelos mais pobres. As tensões podem ficar muito tempo latentes; finalmente, chega o dia em que explodem. As brigas começam em geral no nível das crianças e são depois tomadas a peito pelos pais, trazendo consequiências, às vezes, trágicas. (...) Quando a população deixa o campo e vai para a cidade, os grupos tornam-se desempregados, desorganizados e miseráveis.” (p. 43) Além da violência, outro fator apontado pela autora que como maléfico à educação das crianças e dos jovens é facilidade com que ocorrem as mudanças de cônjuges nesta camada social da população brasileira.

A preocupação expressa por Queiróz, de que os meios mais pobres não possuem não apenas os recursos financeiros, mas também os recursos "morais" necessários para educar seus filhos, é partilhada por Heloísa Marinho, professora do Instituto de Educação do Rio de Janeiro, ao escrever sobre a "Missão da educadora no jardim de infância",234. Para a autora, crianças de meio pobre ou "remediado" chegavam à escola primária com atraso de dois anos em seu desenvolvimento. No jardim de infância, como no lar, as crianças deveriam adquirir hábitos, atitudes, conhecimentos em situações "naturais" da vida: "cabe ao jardim compensar a pobreza proporcionando à criança vida rica em experiências necessárias ao desenvolvimento harmonioso de sua personalidade. (...) A vida social no jardim de infância deve formar hábitos indispensáveis à educação moral e cívica. (...) Sermões não adiantam. As crianças dos apartamentos não possuem vivências sociais, que dão significado a palavras referentes à moralidade" (p. 64). A preocupação com a "delinquiência" dos jovens por conta do meio social no qual viviam também é explicitada por Alberto Ferreira Giúdice ${ }^{235}$, em artigo publicado na RP em 1959. Em sua opinião, a

\footnotetext{
${ }^{233}$ QUEIROZ, Maria Isaura Pereira de. "Infância e adolescência as favelas brasileiras" RBEP, nº117, jan./mar. 1970 , p. $35-49$.

${ }^{234}$ MARINHO, Heloísa. "Missão da educadora no jardim de infância", RBEP, nº 101, jan./mar. 1966, p. 63 72.

${ }^{235}$ GIÚDICE, Alberto Ferreira, "Educação”, RP, set./1959 p. 20.
} 
educação moral e cívica desempenharia um papel importante: "é preciso muito zelo com a educação primária e atenção à educação moral e cívica: pois ninguém negará a imprescindível necessidade de sua aplicação, dado o baixo grau que se pode verificar no ensino primário, com raras exceções. Não tomando providências acauteladoras e saneadoras a respeito, aumentará sempre a delinqüência de menores. E se o menor já é delinqüente... não precisamos dizer mais nada. O Estado líder se fará líder com letra maiúscula, lutemos e esperemos confiantes. A educação escolar está abandonada e a do lar também" (p. 20).

A sociedade brasileira, especialmente as cidades do Rio de Janeiro e de São Paulo, passava por um processo de urbanização desde o início do século XX. Mas foi sobretudo no início dos anos de 1950 que este processo foi intensificado, mantendo índices impressionantes até os anos de 1970. Aliados à urbanização no Brasil, dois fenômenos também marcaram a configuração social no período: a migração (do norte e do nordeste do país para o sul e do interior para a capital) e a industrialização. Os migrantes iriam compor a base social das novas camadas populares urbanas, somando-se aos descendentes dos escravos e dos ex-escravos e dos imigrantes europeus, que desde o final do século XIX constituíam grande parte das camadas populares das capitais do país (PEREIRA, 1976; SKIDMORE, 1982). Em um país de origem colonialista como o Brasil, elementos como a entrada das mulheres no mercado de trabalho e a iminência de revoluções sociais, como a pretendida pelo movimento feminista, ajudam a compreender como um período que via o desenvolvimento industrial e a expansão demográfica contestar os valores sociais tradicionais temia que as reivindicações femininas derivadas desse novo estilo de vida abalassem a instituição que era tida, tanto pelo Estado, quanto pela Igreja, como o alicerce do país. Além disso, na representação da família tradicional, aquela que normalmente era veiculada no material consultado, as mulheres eram as encarregadas dos rituais de manutenção do grupo familiar e de estabelecer relações de integração deste com a comunidade. Esse temor pela destruição ou pela mudança na estrutura familiar era representado nos discursos apresentados nas fontes consultadas pela importância dada à figura das mães e ao seu papel na educação das crianças. Nesse momento histórico, esse elemento também pode ter contribuído para reforçar e perpetuar a idéia de que, nas escolas, as professoras primárias seriam uma espécie de segunda mãe dos seus alunos, contribuindo com o caráter inercial do habitus docente (PEREIRA, 1969; PEREIRA, 2001). 
Segundo Fernando de Azevedo ${ }^{236}$ (1957), um Estado que recebeu tantos imigrantes como São Paulo requeria um trabalho incessante de reintegração social. A "consciência nacional" seria o resultado de formação espiritual de todo o povo. Neste processo, o professor primário era considerado pelo autor como um "artífice da unidade nacional" e os jovens e as crianças eram considerados as maiores riquezas do país. Todos os indivíduos, considerados como "material humano", deveriam ser transformados em "unidades econômicas ou produtivas" que seriam utilizadas nos mais diversos campos das atividades humanas. Nas palavras de Azevedo, "uma educação comum, mais forte e prolongada possível, deve estender-se ao nível das massas, para diminuir os conflitos entre massas e elites" (op. cit, p.60). Todo esse conjunto heterogêneo da população fornecia os contingentes de mão-de-obra necessários para as indústrias que se instalavam no país, mas ele carecia de moralização. As crianças originárias destas famílias eram representadas muitas vezes na literatura consultada como "desajustadas", “anormais", "delinqüentes", mas é possível entendê-las também como pouco conformadas moralmente. A noção de "profilaxia social" tem nuances, mas está bastante explícita no texto de Orlando Parahim $^{237}$, professor e médico, publicado na RBEP em 1965. Ao referir-se às crianças agressivas e com condutas "anormais", como desajustadas ao ambiente escolar, o autor diz o seguinte: “(...) os meninos nascidos e criados em lares desorganizados, os filhos ilegítimos, apresentavam acentuada instabilidade e graves transtornos afetivos; tinham péssima conduta e aproveitamento intelectual quase nulo na escola. Eram pornográficos, mentirosos e brigões. (...) Uma educação adequada pode realizar uma profilaxia nas situações das crianças oriundas de lares desorganizados, filhos de pais separados, alcoólatras, com sífilis e epilepsia. (...) O problema não é certamente de ordem policial, mas de natureza pedagógica por excelência, problema também de higiene social, que começa pela educação preparadora do homem para a sua perfeita integração social.” (p. 149) Parahim explicita a questão que, de fato, parecia ser o cerne do problema: a integração social. Inicialmente ela caberia à família mas, por conta da pobreza, do divórcio

\footnotetext{
236 AZEVEDO, Fernando de. "Horizontes perdidos e novos horizontes (A educação primária na sociedade atual)" RBEP, nº 65, jan./mar. 1957, p. 47 - 64.

${ }^{237}$ PARAHIM, Orlando. "Um inquérito escolar" (publicado inicialmente no Diário de Pernambuco, Recife), RBEP, nº 97 jan./mar. 1965 p. 148 - 149.
} 
e de doenças como a sífilis e o alcoolismo, que implicavam na conduta moral das pessoas, a tarefa ficou exclusivamente a cargo da escola que, além de ensinar a escrever, a ler e a contar, haveria de ensinar uma conduta considerada adequada e que permitiria aos indivíduos a sua plena integração social, apesar de sua origem familiar.

Citada no início do capítulo, a frase de Anísio Teixeira (1958) é bastante ilustrativa acerca da maneira como a conformação moral se apropriou da doutrinação religiosa e da narrativa sagrada: "o dualismo fundamental entre o homem do mundo e o homem de Deus continua através dos séculos até à nossa idade, reduzida a virtude a um investimento na cidade do céu" (op. cit., p. 11). Para que a barbárie não se instalasse, era preciso que os agrupamentos coletivos tivessem subordinação, disciplina, um fim que fosse percorrido por todos e que os metamorfoseassem em uma unidade. Os elementos encontrados nas fontes consultadas que aproximam a idéia do "bom cidadão" à do "bom cristão", evidenciam o quão tênue é linha que separa o discurso laico do discurso religioso nas práticas de moralização nas escolas brasileiras, e principalmente, o quanto eles se misturam. Se o cidadão que habita o Estado-nação precisa acreditar em uma abstração para subordinar-se, o cristão também o faz. O primeiro obedece às leis e às regras para o bom convívio social, a prosperidade e o futuro, e o segundo o faz em busca do "paraíso", da "vida eterna" ou de "um investimento na cidade do céu". Em ambos os casos, a força motriz que torna a subordinação possível é a crença em algo que está no campo da abstração, mas que é tão forte que torna não apenas a existência possível - já que se abre mão do presente em troca do futuro - como também é capaz de acionar revoluções, guerras e rebeliões, porque se trata de uma maneira de sujeitar as pessoas sem que dela seja possível escapar: neste caso, o que está em jogo não é controle do corpo, mas o controle da alma das pessoas e de suas representações. De acordo com o que se pensava no período, seria como se por um feitiço, os indivíduos, livres, desejassem ter uma chance de poder obedecer. No próximo capítulo busca-se explicitar de que maneira o Estado, a exemplo da Igreja, colabora para a construção de práticas e de representações objetivando conformar moralmente os indivíduos. 


\section{Capítulo 5}

\section{EdUCAÇÃo MORAL. E CÍvICA?}

\section{ESTADO, NAÇ̃̃o E PATRIOTISMO}

"La politesse, cher enfant, consiste à paraître s'oublier pour les autres".

Balzac

"A maior das verdades táticas é que os povos se defendem principalmente com o coração de seus soldados".

Rui Barbosa

"Estarrecida ante os extremos a que, em órgãos e serviços ligados à juventude, atingira a corrupção e a subversão de agentes do Poder Público, a Nação adquirira a consciência de que a educação constituía um dos focos em que mais urgente se tornara uma presença saneadora. Daí os aplausos com que tem recebido os esforços do governo para repor a ordem nesse importante setor da vida nacional" (p. 166). Essas palavras são de Humberto Castelo Branco ${ }^{238}$, então presidente da república, e foram publicadas na RBEP, em artigo intitulado "Pela democratização do ensino", no ano de 1965. A necessidade de impor ordem à vida educacional almejada pelo presidente Castelo Branco não consistia em uma iniciativa inédita no setor. Em São Paulo, no período republicano, o governo já tinha como objetivo organizar a educação escolar de modo a preparar o povo para assumir as suas responsabilidades cívicas. O Código de Ensino aprovado em 1928 previa que as escolas de tipo único, uniformes em suas "bases humanas e nacionais" promovessem uma "educação integral - física, moral, intelectual e cívica" (AZEVEDO, 1957). Em momentos em que o Estado precisa da adesão imediata dos indivíduos às suas idéias é ao sistema educacional que ele recorre, modificando-o e organizando-o. O sistema de ensino corresponderia então às exigências da sociedade, "tendo por base de sua unidade e coesão

\footnotetext{
${ }^{238}$ CASTELO BRANCO, Humberto. (Presidente da República) "Pela democratização do ensino" RBEP, $\mathrm{n}^{\circ}$ 98, abr./jun. 1965, p. $165-167$.
} 
social um mínimo de semelhanças entre os indivíduos, grupos e subgrupos que a compõem, tomam como ponto de partida a assimilação (homogeneização) dos indivíduos (ensino geral, comum) para as diversificações ulteriores, nas escolas especializadas" (op. cit, p. 50) Segundo Fernando de Azevedo (1957), a escola primária trazendo sempre os "traços característicos da cultura do país a que serve" seria um dos mais poderosos fatores de assimilação, porque disseminaria por todo território uma mesma cultura intelectual e moral, básica e comum, assegurando a coerência e a unidade interna: a escola seria o instrumento de assimilação de todos a uma cultura nacional: "a assimilação é a lei da vida nacional, a passagem do heterogêneo ao homogêneo, contando com um conjunto de instituições que contribuem para o desenvolvimento das sociedades: família, língua, religião, Estado, cidades" (p. 52). Acerca da função da escolarização na formação do sentimento de nacionalismo, Azevedo cita Félix Pécaut (1828-1898), pedagogo francês considerado um dos principais idealizadores da educação republicana, afirmando que "quando se fala no papel nacional da escola, pensa-se sobretudo "em sua utilidade para a prosperidade material ou para a moralidade da nação. Mas a verdade fundamental é outra. É que a escola faz a nação: ela é um dos instrumentos mais poderosos de assimilação e de integração social e cultural"”(p. 54 grifos meus). Essa idéia de que a "escola faz a nação", que esteve muito presente no período republicano, foi constantemente evocada nas décadas seguintes e mereceu atenção especial durante a ditadura militar. Para alcançar a ordem social pretendida nas palavras de Castelo Branco, era preciso que a ordem estivesse presente nas escolas e para que as escolas "fizessem a nação" elas precisariam operar ordenando a formação e o trabalho dos seus agentes. Nesse caso, a atenção seria voltada para os professores primários e para os seus alunos.

Mediante o exame das fontes consultadas para a realização deste trabalho, foi possível perceber uma orientação patriótica da moral. Os valores e os fins sociais que a educação moral propunha às crianças durante seu processo de escolarização e aos professores, durante a sua formação, contribuiriam para a permanência do próprio ideal de nação. No verbete acerca do termo "Estado", da Pequena Enciclopédia de Moral e Civismo, publicada pelo Ministério da Educação e da Cultura (MEC), em 1967, há uma definição que é bastante ilustrativa acerca dos propósitos desta orientação referida anteriormente. Definindo o Estado como um "instrumento do bem comum (...) no plano dos meios, ou da execução dos fins, as pessoas se subordinam ao Estado, isto é: como 
obrigação moral, de consciência, devem a ele submeter-se em todas as suas justas exigências tendentes à promoção do bem comum” (p. 202). De acordo com o mesmo livro, a nação seria entendida como: "conjunto estruturado de instituições, entre as quais o Estado, nas quais o povo se organiza, ou mais exatamente, é o povo enquanto organizado no conjunto de instituições pelas quais ele tende à realização de seus objetivos e aspirações." (p. 203) O conceito de pátria, por sua vez, ainda de acordo com a publicação do MEC, "focaliza mais a idéia da continuidade histórica do povo e da nação, continuidade garantida pela sucessão das gerações e pela transmissão de um patrimônio cultural comum, e a idéia de uma referência a um espaço geográfico, a um território, no qual se desenrola a vida do povo, o solo pátrio herdado dos maiores para ser enriquecido, humanizado e transmitido às gerações vindouras” (p. 203). Acerca a construção da representação de Estado, vale a pena retomar as palavras de Pierre Bourdieu (1996), para quem "o Estado é resultado de um processo de concentração de diferentes tipos de capital, capital de força física ou de instrumentos de coerção (exército, polícia), capital econômico, capital cultural, ou melhor, de informação, capital simbólico, concentração que, enquanto tal, constitui o Estado como detentor de um metacapital, com poder sobre os outros tipos de capital e sobre seus detentores. A concentração de diferentes tipos de capital (que vai junto com a construção dos diversos campos correspondentes) leva, de fato, à emergência de um capital específico, propriamente estatal, que permite ao Estado exercer um poder sobre os diversos campos e sobre os diferentes tipos específicos de capital, especialmente sobre as taxas de câmbio entre eles (e, concomitantemente, sobre as relações de força entre seus detentores). Segue-se que a construção do Estado está em pé de igualdade com a construção do campo do poder, entendido como o espaço de jogo no interior do qual os detentores de capital (de diferentes tipos) lutam particularmente pelo poder sobre o Estado, isto é, sobre o capital estatal que assegura o poder sobre os diferentes tipos de capital e sobre sua reprodução (notadamente por meio da instituição escolar)". (op. cit., p. 99 - 100) De acordo com o autor, exercendo poder sobre os diversos campos e sobre os agentes, é por meio dos sistemas de classificação inscritos na legislação, dos procedimentos burocráticos, dos sistemas escolares e dos rituais sociais, que o Estado molda estruturas mentais e impõe maneiras de pensar, princípios de visão e de divisão comuns, contribuindo para a construção daquilo que é conhecido como identidade nacional. É especialmente por meio da escola, com a generalização da educação primária no século XIX, que se exerce a "ação unificadora" do Estado no âmbito da cultura, elemento fundamental para a construção do 
Estado-nação. Ao impor uma cultura nacional considerada legítima, o sistema escolar, nas palavras do autor, "particularmente através do ensino da história e, especialmente, da história da literatura, inculca os fundamentos de uma verdadeira 'religião cívica' e, mais precisamente, os pressupostos fundamentais da imagem (nacional) de si” (op. cit., p. 106). Ao forjar uma imagem de si, o Estado alcança a adesão de seus agentes a ela na medida em que consegue a imposição da língua e da cultura dominantes tomadas como legítimas pela rejeição de todas as outras como indignas - e o faz mediante a escolarização dos indivíduos. A legitimidade do Estado pelos agentes se dá através da concentração de um capital simbólico de autoridade reconhecida. De acordo com Bourdieu "o capital simbólico é uma propriedade qualquer (de qualquer tipo de capital, físico, econômico, cultural, social), percebida pelos agentes sociais cujas categorias de percepção são tais que eles podem entendê-las (percebê-las) e reconhecê-las, atribuindo-lhes valor” (op. cit., p. 107). Trata-se então da forma que todo capital assume no momento em que é reconhecido através de categorias de percepção, como forte ou fraco, rico ou pobre, etc. O Estado, por dispor de meios de impor e de inculcar princípios de visão e de divisão de acordo com as suas estruturas, é o lugar por excelência de concentração e de exercício do poder simbólico.

Pertencendo ao seu meio social mais próximo e ao seu país, os indivíduos são ligados aos seus compatriotas pela língua, pelas idéias, pelas emoções e pelos sentimentos comuns derivados dessa mesma origem. A aprendizagem e a vida na escola, em particular na escola primária, acentuaria ainda mais a consciência desse pertencimento à comunidade nacional. $\mathrm{Na}$ escola, as crianças aprenderiam a conhecer a vida de seus ancestrais, o passado dos homens de seu país, suas lutas, seus sucessos e seus fracassos. Elas teriam consciência do esforço das gerações anteriores para o progresso, da solidariedade que os ligariam ao passado e ao presente. A história e a geografia, ensinadas através dos estudos sociais no âmbito do ensino primário, e a literatura nacional lhes fariam compreender as características da nação. Jaime Abreu $^{239}$, então diretor da divisão de estudos e pesquisas educacionais do CBPE, em artigo publicado na RBEP em 1961 sobre os estudos sociais na escola média, apontava para o fato de cientistas sociais e educadores norte-americanos estarem chamando a atenção para o entendimento das "áreas fechadas da cultura", que

\footnotetext{
${ }^{239}$ ABREU, Jaime. "Os estudos sociais na escola média” RBEP, no 82, abr./jun. 1961, p. 151 - 154.
} 
seriam áreas de crença e comportamento caracterizadas por uma relativamente larga soma de "irracionalidade, preconceito, inconsistência, confusão e tabus" (p. 152). Para o autor, a própria noção de classe social não era entendida nas escolas de forma clara: "prevalece espalhado o estereótipo de que não há classes sociais na América. Admitir o contrário acarreta o risco da conotação emocional de se tratar de teoria de "comunistas"” (p. 153). Além disso, sobre sexo, moralidade e religião prevaleceriam tabus e dogmatismos. O ensino, associado às práticas escolares, poderia potencializar a crença subjetiva numa origem comum que une indivíduos distintos, fazendo-os pensar em si mesmos como membros de uma coletividade. A educação moral, neste processo, faria com que as pessoas partilhassem os mesmos valores, medos e aspirações, fazendo nascer nos alunos o amor ao seu país, o sentido do dever para com ele como homem, como cidadão e como trabalhador em sua atuação profissional. Nos anos de 1960, importância crescente na vida pública era dada à escola em todo o país mediante a defesa de uma "educação nacional" que, aliada à disciplina, ao conhecimento e às práticas, visaria à promoção da ordem e ensinaria que o progresso da humanidade, ao longo da história, teria consistido na conquista de um certo número de idéias morais válidas para a humanidade toda: respeito da pessoa humana e de toda a sua dignidade, integridade, tolerância, justiça e fraternidade. Colocando em evidência a necessidade de cooperação e de solidariedade entre os povos, a necessidade de promover a paz, apesar da diversidade, os professores perpetuariam, através do seu trabalho com os alunos, os princípios fundamentais da moral humana, evocando-os a todo a momento na vida escolar.

Perseguindo a idéia de que as práticas de moralização na escola pública brasileira podem ter sido exercidas mediante três formas distintas e complementares, localiza-se a terceira delas como sendo aquela exercida pelo Estado ou em "nome da Pátria". Esta forma de a moral ser apresentada no âmbito escolar, no caso brasileiro, pode ser aquela que mais se assemelha à moral laica francesa, que, segundo Delphine Mercier (2005) construiria a supremacia da razão, o respeito da dignidade humana e a primazia das liberdades individuais. Esta moral não diz respeito somente ao desejo de uma normatização dos comportamentos individuais, mas garante também a conservação do Estado. Mais que uma simples instrução ou um novo catecismo, este novo ensino estabelece as obrigações morais das crianças na família e na escola e funda, para os adultos, uma sucessão de deveres individuais e sociais (CASPARD, 2010). Sendo concretizada mediante o conjunto 
de interesses e de esperanças das pessoas, a pátria se confunde com um Estado republicano cujas benfeitorias são fonte da união nacional. Na França, o objetivo fundamental da formação moral na escola primária, seria o de valorizar a relação com o trabalho escolar e depois profissional, forjando assim um lugar social que justificaria o patriotismo. A adaptação à vida escolar e a uniformização dos comportamentos que ela implica constituem um momento prévio, uma espécie de ensaio de integração da criança na sociedade. Redefinir as atitudes cotidianas dos alunos equivale a formar os estudantes modelo, na esperança de fazer, mais tarde, cidadãos livres e úteis, pois serão instruídos e esclarecidos. A obediência continua sendo a principal virtude escolar, a criança deve se conformar aos preceitos anunciados, de maneira mecânica e dócil. Lugar de aprendizagem da vida social, a escola republicana tece o primeiro lugar entre o direito e o dever, cumprindo o seu papel social. O tema do progresso nacional é relido então de outra forma: constituído pelo direito de cada um de instruir-se e oferecer a todos uma progressão social, ele impõe, reciprocamente, os deveres. De acordo com o ideal republicano, através do ensino moral dos mais jovens é que seriam impostos os novos fundamentos sociais e cívicos da nação.

Nas fontes examinadas, foi possível identificar que a questão cívica associa-se também à noção de integração à comunidade. A noção de caridade, tão enunciada nos textos que tratam da moral religiosa, é substituída então, ao se tratar da moral laica, pela noção de civismo. Termo este que freqüentemente é acompanhado de outros dois: civilidade e cidadania. As três palavras se complementam porque o "civismo" refere-se a atitudes e comportamentos do "bom cidadão", visando preservar a vida coletiva e o bemestar de todos, a "civilidade" trata da polidez ${ }^{240}$, de um conjunto de comportamentos sociais que exprimem o apreço e o respeito de um indivíduo pelo outro, e a "cidadania" está associada à noção de direitos e de respeito à República. Em artigo intitulado "A criança e o civismo", publicado na RP em 1963, o professor primário Mena Pinheiro ${ }^{241}$ afirmava que a escola deveria ensinar a noção exata da responsabilidade perante o voto. Segundo Pinheiro, "é preciso convencer o nosso aluno de que 'o cumprimento do dever

\footnotetext{
240 "Politesse" (termo francês). Equivale a um conjunto de ritos, de regras que regem o comportamento, a linguagem, considerados como os melhores de uma sociedade; delicadeza, bom gosto, bom senso.

${ }^{241}$ PINHEIRO, Mena. “A criança e o civismo”, RP, Jan./Mar., 1963, p. 33.
} 
não é subordinado à condição de que os outros também o cumpram', pois cada um de nós, (não obstante ser com os outros uma só comunidade), responde pessoalmente por seus atos. É preciso formar no Brasil um novo clima, onde o cidadão respeite e se faça respeitar”. (p. 33) Se no Código de Educação do Estado de São Paulo, decreto n ${ }^{\mathbf{5} .884}$, de 21 de abril de 1933, não há nada específico sobre a educação moral e na Lei de Diretrizes e bases da educação nacional, promulgada em 1948, apenas é dito que é necessário cuidar da formação do caráter e da moral e "a escola primária tem a finalidade de integração social e de adestrar a criança nas técnicas elementares de ler, escrever e contar, incutindo-lhes princípios e atitudes intelectuais e morais". (p. 21), é pelas mãos dos militares, que a educação moral, associada ao civismo fez dela uma disciplina e instituiu a sua obrigatoriedade nas escolas de todos os graus e modalidades do sistema de ensino no país, através do decreto-lei $\mathbf{n}^{\circ} \mathbf{8 6 9}$ - de 12 de setembro de 1969. O $2^{\circ}$ artigo do decreto-lei exprime as suas finalidades: "a defesa do princípio democrático, através da preservação do espírito religioso, da dignidade da pessoa humana e do amor à liberdade com responsabilidade, sob inspiração de Deus; (...) fortalecimento da unidade nacional e do sentimento de solidariedade humana; (...) o aprimoramento do caráter, com apoio na moral, na dedicação à família e à comunidade; (...) o preparo do cidadão para o exercício das atividades cívicas, com fundamento na moral, no patriotismo e na ação construtiva, visando ao bem comum. (...) É criada, no Ministério da Educação e Cultura, diretamente subordinada ao Ministro de Estado, a Comissão Nacional de Moral e Civismo (CNMC). Cabendo a ela, articular-se com as autoridades civis e militares, de todos os níveis de governo, para implantação e manutenção de doutrina de Educação Moral e Cívica." A disciplina não deveria ser apenas responsabilidade da escola, mas deveria também ser objeto de educação assistemática, realizada dentro da comunidade. Implementada no período da ditadura militar, que vigorou de 1964 a 1984, pretendia-se que a disciplina "Educação Moral e Cívica" moldasse os comportamentos e doutrinasse as pessoas. Tratava-se então de um certo ajustamento do indivíduo à nova ordem política vigente, legitimando o governo militar. É importante observar o quanto, como foi mencionado anteriormente, o religioso e o laico se misturam nas questões nacionais. No próprio texto do decreto-lei citado, as noções continuam postas: "a defesa do princípio democrático, através da preservação do espírito religioso, (...) sob inspiração de Deus”. Durante a implementação da Educação Moral e Cívica, a Igreja Católica posicionou-se favorável à sua proposta, por verificar que a disciplina se fundamentaria em valores religiosos 
(OLIVEIRA, 1982). A associação entre religião e Estado, no âmbito das práticas de moralização, não seria explicada apenas pela manutenção de uma hegemonia, por ser a Igreja católica a mais influente e a mais representativa do país. Certamente o fato de o catolicismo ter participado intensamente da colonização no Brasil teve seu papel neste processo, mas a religião, embora se apresentasse legalmente separada do Estado, possuía uma narrativa que era fundamental para conquistar a cooptação das massas, e não se poderia abrir mão disso. Durkheim pretendia criar uma ciência que fosse capaz de despertar nos homens o amor à pátria, sendo preciso estabelecer laços entre as crianças e a pátria. Contudo, o que houve na França foi a construção de um patriotismo "científico" porque esses laços foram estabelecidos isolados da questão religiosa, que traz consigo a noção de fé e com ela a adesão completa do indivíduo ao desconhecido, àquilo que não se pode provar. No Brasil, também era preciso desenvolver nas crianças o patriotismo, principalmente durante o governo militar, mas as crenças não deveriam ser somente dirigidas à pátria, eram também voltadas a Deus. Esta ambigüidade marca o caso brasileiro. Elemento principal da narrativa do sagrado, a fé esteve presente na educação brasileira desde as suas origens, tendo os padres como os seus primeiros professores. Se educação e doutrinação caminharam juntas desde os primórdios, não seria simples a sua separação. Assim como a moral laica, defendida por Durkheim, a moral religiosa também é formada por um conjunto de comportamentos cuja principal função é garantir a coesão social do grupo. Para o governo militar, contar também com a moral religiosa e instituí-la no âmbito de uma disciplina escolar obrigatória representou a união de dois discursos a favor de uma mesma causa.

Em 1954, Afro do Amaral Fontoura, no manual pedagógico Fundamentos da Educação, dizia que a educação moral e cívica e a sociologia deveriam estudar o homem como membro da comunidade, cabendo às ciências sociais despertar o patriotismo, desenvolver uma consciência moral e econômica, formar o indivíduo útil à sociedade e à família. Os objetivos específicos da educação moral e cívica seriam: desenvolver as qualidades morais, amor à verdade, honestidade, solidariedade, respeito às instituições pátrias e à sociedade. Para endossar o discurso, Fontoura cita Jacques Maritain (1882 1973), filósofo francês de orientação católica, influenciado por São Tomás de Aquino (1225 - 1274), que escreveu dezenas de obras que influenciaram a renovação do pensamento tomista no século XX e a ideologia da "Democracia Cristã", mas que não 
tiveram repercussão na literatura pedagógica francesa. Para ele, a educação deve mirar o grupo social e o papel que o homem nele desempenha; formando o homem para cooperar com a comunidade. Com relação à metodologia das disciplinas, a geografia seria a responsável por desenvolver o amor à Pátria e por integrar a criança ao meio social, a história seria ministrada como instrumento de educação cívica, despertando o "espírito cívico", o amor à nação e à Pátria, trabalhando pela compreensão dos valores de seu país, do caráter dos homens e dos cidadãos, germinando os ideais de civismo, o sentimento de "brasilidade" e o amor às tradições nacionais. As ciências naturais deveriam criar hábitos de asseio com o corpo e o vestuário, fortalecer o amor ao trabalho e o patriotismo através do estudo das riquezas nacionais e conhecimento dos grandes vultos nacionais que contribuíram para o progresso da ciência. (p. 240) Cita o pedagogo alemão Georg Michael Kerschenstein (1854 - 1932), discípulo de Dewey, criador das "escolas do trabalho", que fundou uma pedagogia que valoriza a inteligência prática, orientada para o trabalho e o sucesso profissional, e que fez da história um instrumento da educação cívica. A visão da disciplina história apresentada por Fontoura também é partilhada por Rafael Grisi no livro Didática mínima, que em 1956 estava na sua $3^{\text {a }}$ edição. Para ele, a "escola precisa principalmente comunicar às novas gerações, os hábitos, habilidades, atitudes e valores culturais, padrões de pensamento e de trabalho e de vida" (p. 83). Mais especificada do que aparece no livro de Fontoura, a metodologia do ensino de história é acompanhada de "questões de observação". Em história do Brasil deveriam ser trabalhadas as comemoração de datas cívicas, os feriados nacionais, os vultos "notáveis da História da Pátria". (p. 79) Em seguida surgiriam as questões: "Os fatos visaram favorecer a formação moral, sentimentos de civismo? Melhor compreensão de normas de conduta? Maior sentimento de amor ao Brasil?" (p. 80). Para Grisi, a escola deveria formar o membro eficiente da sociedade e as suas atitudes deveriam ser ajustadas ao convívio social. O empenho do trabalho educativo seria o de reforçar as boas e transformar e eliminar as más atitudes. Alguns hábitos deveriam ser cultivados e desenvolvidos, tais como: a honestidade, a lealdade, a veracidade e as boas maneiras. Eram considerados valores educativos "reais": a higiene, o trabalho; e ideais: a vida sadia, "normal" e digna, o civismo e o patriotismo. Tais aspectos afetariam tanto a personalidade quanto ao caráter dos alunos. A história deveria então favorecer a formação moral e desenvolver sentimentos cívicos, valorizando os “símbolos da Pátria" (p. 171), acentuando a "personalidade dos vultos históricos" (p. 173), focalizando a "força viva do exemplo" através das personalidades estudadas, em todos os 
setores da história, procurando colaborar na obra de "engrandecimento nacional; canto de hinos, música e letra" (p. 174-175). Também caberia à disciplina promover comemorações cívicas, das "grandes datas nacionais", culturais e religiosas. A disciplina geografia deveria despertar e desenvolver o interesse pelos problemas nacionais. Grisi também enfatiza o papel do professor com relação ao desenvolvimento dos sentimentos de civismo na escola. Para ele, a personalidade do professor deveria ser um exemplo de engajamento na valorização e na defesa do território nacional.

\subsection{A EDUCAÇÃO, O TRABALHO E A MOBILIDADE SOCIAL}

“A escolarização é importantíssimo fator de desenvolvimento sócio-econômico". A afirmação é de Moysés Brejon ${ }^{242}$, professor da Universidade de São Paulo, em artigo publicado na RBEP em 1965. Brejon evidenciava que as mais variadas formas produtivas eram favorecidas mediante a ação exercida pela educação para o desenvolvimento das aptidões intelectuais do educando, bem como para a sua capacidade física, para a sua formação moral e na preparação para o trabalho. Normalmente ficava explícita a idéia de que, ao preparar para o trabalho, a escola também estava contribuindo para a ascensão social do indivíduo. Além disso, o processo de industrialização pelo qual a sociedade passou durante o governo militar, também exerceu influência sobre as escolas, que deveriam formar indivíduos que fossem aptos ao trabalho, adquirindo as habilidades necessárias para exercer atividades nas indústrias, influenciando na moralização das pessoas. Anísio Teixeira ${ }^{243}$, em artigo publicado na RBEP em 1956, observa que, com o crescimento das organizações humanas, elas acabaram apresentando um aspecto "unificante e uniformizante", e isso seria uma tendência daquela época. Para autor, tal fato seria decorrente do caráter mecânico da industrialização e da produção em massa, que

\footnotetext{
${ }^{242}$ BREJON, Moysés. "Educação, fator de produção" (publicado inicialmente no jornal O Estado de S. Paulo), RBEP, no 99, jul./set. 1965, p. $207-208$.

${ }^{243}$ TEIXEIRA, Anísio. “A administração pública brasileira e a educação”, RBEP, nº 61, jan./mar. 1956, p. 3 -23 .
} 
acabaria afetando as relações sociais. Outro ponto de vista tem Alberto Ferreira Giúdice ${ }^{244}$, diretor de grupo escolar, apresentado em artigo publicado na RP em 1959. Para ele, a industrialização "traz um peso excessivo para o valor cultural e educacional de cada um de nós": "toda crise social traz uma nova forma de vida, benéfica ou não ao povo. O professor deve remover a causa do mal que é a ignorância. Os nossos patrícios devem ser merecedores da acolhida em qualquer empresa ou indústria para trabalhar. Quanto mais adiantado for um povo, maior seu progresso material e moral. Contribuamos para a diminuição do número de ignorantes que são um peso morto na balança da sociedade e estaremos trabalhando patrioticamente. Quanto maior o número de patriotas, maior o valor do Brasil'". (p. 8)

Cora Bastos de Freitas Rachid ${ }^{245}$, técnica de educação do MEC, em artigo publicado na RBEP em 1972, afirmava que a escola deveria oferecer habilitação, estimular e aperfeiçoar interesses, aptidões, hábito de cooperação, juízo, lealdade e conduta de trabalho naqueles que está preparando. Tais comportamentos deveriam ser incorporados à personalidade. Para ela, a formação profissional visaria à consecução de certos prérequisitos que o sistema empresarial exigia dos que nele ingressavam. A realização profissional seria alcançada se a escola tivesse oferecido o instrumental hábil para a execução das tarefas que caberiam aos indivíduos na vida do trabalho. O que nem sempre ficava explícito nos textos veiculados nos periódicos educacionais é que, ao preparar o indivíduo para o trabalho, também se estava contribuindo para a formação da sua personalidade, o desenvolvimento de atitudes e o ajustamento das pessoas à sociedade. A questão leva a outro aspecto da concepção sociológica da educação moral: a orientação social. Ela consiste em dirigir as crianças para funções úteis ou necessárias à sociedade, levando em conta, somente em segundo plano, os gostos individuais. O desenvolvimento e a importância crescente da vida econômica e social teria imposto ao ensino uma orientação e uma preparação profissional e cívica que levaria cada um a cumprir melhor o seu papel. Mas não seria desejável obrigar os indivíduos a satisfazer exclusivamente as necessidades de uma sociedade determinada: seria preciso levá-los desejar satisfazer tais necessidades.

\footnotetext{
${ }^{244}$ GIÚDICE, Alberto Ferreira. "Conseqüências de uma industrialização inesperada”, RP, out./nov. 1959, p. 8.

${ }^{245}$ RACHID, Cora Bastos de Freitas. "Habilitações profissionais da área terciária”, RBEP, nº 125, jan./mar. 1972, p. $97-109$.
} 
Nas escolas, pensava-se na formação do cidadão, mas pensava-se também na formação do trabalhador obediente, ordeiro e disciplinado.

A educação tendo por finalidade o trabalho ou a preparação para o trabalho é um aspecto bastante recorrente nas fontes examinadas. Isto deve-se em parte à idéia que, para que o indivíduo seja útil à sociedade, é preciso que ele seja produtivo. Neste caso, seria preciso formar o "homem eficiente no seio da pátria"246, eficiência esta dirigida ao trabalho desenvolvido na sociedade industrial. Na escola, as crianças poderiam desenvolver hábitos de trabalho ${ }^{247}$, compreender o funcionamento da vida econômica da comunidade e da nação, a dignidade do trabalho e as atitudes do bom produtor e do bom consumidor ${ }^{248}$. De acordo com Boletim da UNESCO ${ }^{249}$, publicado na RBEP em 1970, a educação exerce influência indireta múltipla sobre a economia: podendo aumentar o senso de iniciativa e as faculdades inventivas, melhorando os esquemas de consumo e favorecendo a mobilidade econômica e social. No livro Introdução ao Estudo da Escola Nova, reeditado em 1965, Manuel Bergström Lourenço Filho também trata da questão do civismo na escola, da educação e da manutenção do Estado, da formação do indivíduo e de sua subordinação à vida política e moral do grupo. Para ele, "a Escola Nova deve preparar o futuro cidadão a preencher seus deveres com a pátria e com a humanidade" (p. 165). Para isso, a integração não se dá fora da vida social, ela reclama a assimilação de hábitos, de ideais e de crenças do grupo em que vivam os alunos, e a compreensão de que a pessoa e o meio social não se isolam, mas são interdependentes. De maneira distinta dos outros autores dos manuais pedagógicos examinados, a maneira de moralizar mediante o desenvolvimento do espírito cívico e a integração do indivíduo à sociedade é feita neste caso mediante uma série de

\footnotetext{
${ }^{246}$ GIONGO, Alberto Bruno. “A orientação educacional e o professor”, RP, jul./1959, p. 29.

${ }^{247}$ MENDONÇA, Nunes. (Correio de Aracaju, Aracaju) "Educação e progresso social" RBEP, nº 62, abr./jun. 1956, p. $149-153$.

${ }^{248}$ CAMPOS, Paulo de Almeida. "Seminário regional sobre planos e programas da escola primária", RBEP, no 64, out./dez. 1956, p. 73 - 93. Trata-se do "Informe Final" do "Seminário regional sobre planos e programas da escola primária", promovido em maio, no Peru, pela UNESCO e pela OEA, visando ao estudo dos problemas relativos à generalização da educação primária gratuita e obrigatória na América Latina.

249 “Ano Internacional da Educação" ADISESHIAH, Malcolm S. (Informações da UNESCO, janeiro 1970 e Boletim da AIU, V. XVIII, 1970, n. 1) (artigo é de autoria do Diretor-Geral Adjunto da UNESCO,foi traduzido do francês pelo Prof. Celso Barroso Leite) RBEP, nº 119, jul./set. 1970.
} 
citações de outros autores, principalmente estrangeiros. Partilhando dos ideais escolanovistas, o livro trata das atividades com finalidade moral, visando a estabelecer determinada ordem social, a partir da organização de séries de projetos que ilustravam o equilíbrio e a necessidade da ordem social. Questões como a extensão da obrigatoriedade escolar também eram justificadas pela vertente da moral porque era defendido que ela procuraria evitar que houvesse um hiato entre o término dos estudos primários e o ingresso no mercado de trabalho, o que seria prejudicial à formação moral e cívica, sobretudo nas cidades em que o "poder educativo no lar se debilitava" (p. 257). Pensava-se que com o rápido ingresso no mercado de trabalho e com as obrigações que isso acarretaria, o indivíduo estaria protegido das más seduções, que produziriam comportamentos desviantes e abalariam a ordem social e a vida em comunidade.

Para tratar da oposição entre o natural e o ideal, a expansão do indivíduo e a sua subordinação à vida política e moral do grupo, Lourenço Filho citou o pedagogo francês René Hubert. Ao discutir a importância da educação na formação cívica, na manutenção e defesa do Estado e do governo e nas obrigações que cada um deve impor à sua própria conduta, o educador Isaac Kandel (1881-1965) e o sociólogo Donald Pierson (1900-1995), ambos norte-americanos, são citados. Para reforçar a idéia de que a formação moral deve ser atendida a todo momento na vida escolar, sobretudo no trabalho em comunidade, Lorenzo Luzuriaga é citado. O pedagogo norte-americano John Dewey (1859 - 1952) é citado quando o autor faz referência à democracia e à educação. Para ele, a eficácia social não é alcançada por coação negativa, mas pelo sim uso positivo das capacidades individuais da cada um, em ocupações que tenham significações de ordem social. As influências do movimento renovador da educação também podem ser observadas em outro manual pedagógico analisado, Didática Geral, de Afro do Amaral Fontoura, reeditado em 1965. Para o autor, além de ministrar os conteúdos disciplinares, é tarefa da escola cuidar da "personalidade" das crianças e trabalhar pelo engrandecimento da pátria brasileira. As qualidades morais são consideradas a base da vida humana; cultivá-las é o primeiro dever da escola: "não adianta saber matemática se é desonesto, violento, preguiçoso, revoltado, inimigo do trabalho". (p. 494) A noção de comunidade também está presente no livro e, ao tratar da educação como socialização, Fontoura afirma que o indivíduo isoladamente perdeu sua expressão: "para a comunidade, por ela e dentro dela a educação deve seguir os novos caminhos" (p. 122). Jonh Dewey também é citado na afirmação de que a Escola 
Nova procura preparar o aluno para a vida, por isso deve organizar-se como "uma sociedade em miniatura" (p. 121) e desenvolver nos alunos o espírito de comunidade, tal como existia antigamente nas comunidades religiosas: ordens e congregações. O pedagogo Lourenço Filho também é citado ao afirmar que a criança deve aprender a cooperação e a solidariedade. O pedagogo alemão Georg Michael Kerschensteiner (1854 - 1932), discípulo de Dewey, é citado quando o autor trata do espaço em que a educação moral deverá ter nas práticas escolares. Para ele, a formação moral deve ser atendida a todo momento da vida escolar e no trabalho em comunidade.

Luiz Alves de Mattos, no livro Sumário de didática geral, reeditado em 1967, também incorpora os elementos do civismo nas prescrições feitas aos professores e o caráter preventivo e corretivo também é bem marcado no texto: "a Didática Moderna está toda empenhada no trabalho educativo de reforçar boas atitudes e transformar as negativas do ponto de vista social e moral" (p. 112). Para ele, o fenômeno educativo é irredutível porque, apesar da sua relação com os demais fenômenos que integram a vida em sociedade, como o econômico, o político, o moral, ele não se identifica nem se confunde com nenhum deles, mas se destaca como gerador dos demais. A educação deve ter como objetivo o progresso e este seria conquistado mediante a formação das novas gerações. A melhoria da vida social seria alcançada através do desenvolvimento de atitudes morais e da consciência patriótica, do compromisso com os deveres cívicos e profissionais, habilitando o indivíduo para o convívio no ambiente familiar, profissional e na sociedade como um todo. Ao reforçar a idéia de que a educação tem o poder de eliminar os males sociais, John Dewey é citado. A filosofia da "social efficiency", de influência norte-americana, também está presente no texto: eficiência cívica, como membro da comunidade e eficiência ética e moral, com a aquisição de virtudes morais e sociais para a segurança, o bem estar e o progresso do grupo social ao qual o aluno pertence. Em oposição à teoria behaviorista, para Mattos não basta o indivíduo dispor de automatismos, é necessário que ele também seja dotado de elementos emotivos de caráter moral, como ideais e atitudes, "típicos de uma pessoa educada e integrada no seu meio social e na sua profissão" (p. 108). Os referidos elementos emotivos de caráter moral seriam conquistados mediante o desejo de ter uma vida sadia e feliz para si e para os seus semelhantes; de civismo, respeito às leis e aos problemas coletivos; de justiça, solidariedade, respeito aos direitos dos outros. (p. 110) Ao tratar do manejo da classe e do controle da disciplina, as orientações são dadas com o 
objetivo de promoverem e assegurarem um ambiente ordeiro e disciplinado na classe e incutir nos alunos hábitos sociais e morais indispensáveis ao estudo e à vida em sociedade.

Livro publicado após a instituição da obrigatoriedade da disciplina de Educação Moral e Cívica nas escolas, o que ocorreu no ano de 1969, A escola renovada, de Aldo Perracini, 1972, discute demoradamente sobre os valores cívicos e morais. O psicólogo suíço Édouard Claparède (1873 - 1940) é citado por afirmar que a educação deve desenvolver funções intelectuais e morais e deve despertar o amor ao trabalho. Cabendo ao professor estimular interesses e criar necessidades intelectuais e morais, prosseguindo e acentuando a estruturação de valores morais, cívicos e humanísticos, "promovendo o engajamento do adolescente nas estruturas sociais existentes, desenvolvendo nele ideais de renovação norteada pela justiça, pelo respeito aos direitos alheios e por autêntica solidariedade humana". (p. 10) No planejamento da disciplina Educação Moral e Cívica, são tratados temas como: o desenvolvimento do Brasil, o trabalho, os símbolos nacionais, a pátria e as comemorações cívicas, os grandes vultos da História Brasileira, a sociedade e a administração da cidade. As fábulas, como "A cigarra e a formiga", por exemplo, aparecem enquanto um recurso didático importante para o trabalho com os valores morais na classe. Títulos como "Ninguém mais segura esse país" (p. 82), que deveria ser tratado na quarta série, dão nome aos eixos temáticos para o conteúdo programático do semestre e evidenciam o período histórico marcado pelo governo militar e o reforço do sentimento de nacionalismo.

Outro autor que também explicita ao longo do texto a importância da disciplina Educação Moral e Cívica no currículo escolar é Imideo Giuseppe Nérici. No livro Ensino renovado e fundamental, reeditado em 1975, é dito que é tarefa da educação escolar formar cidadãos participantes, despertar o amor à pátria e a fidelidade à família, e cabe à Educação Moral e Cívica conscientizar os alunos sobre os deveres de cada um para com a família, a sociedade e o país. O filósofo francês Henri Bergson (1859 - 1941) é citado ao tratar da importância da formação sócio-moral do educando, dos direitos e dos deveres para com a comunidade e o semelhante (p. 21). Tal sensibilização para a vida democrática deveria ser alcançada através de ensinamentos os mais práticos possíveis. Neste livro, a orientação para o desenvolvimento de práticas de moralização das condutas, como as obrigações para com os outros, proteção, ajuda e respeito, se dá também mediante a autoeducação: cada um deve tomar conta de si e "se sentir auto-obrigado a respeitar a criatura 
humana" (p. 57) Para Nérici, deve haver uma orientação do comportamento social desejável, "formar é indicar o uso sócio-moral de uma coisa". (p. 35) É necessário predispor a criança para o trabalho e controlar os comportamentos conforme exigem as circunstâncias sociais. As festas, por exemplo, "devem ser feitas na escola para ensinar o aluno a se comportar também nessas situações". (p. 80) Tal controle também pode ser trabalhado quando o aluno é levado a identificar-se com o seu próprio sexo, por exemplo. (p. 81) No programa do ensino da disciplina, está a conscientização sobre os deveres de cada um para com a família, a sociedade e a pátria. A idéia seria formar para o engrandecimento da Pátria: "levar o educando a considerar a vida comunitária, do país, da humanidade e de Deus. Admiração pelos bons exemplos, respeito ao próximo, coragem para repelir as indignidades e sentir-se responsável como cidadão consciente e eficiente" (p. 104), “conhecer a veracidade, verdade, em seus aspectos positivos e negativos. Vivência, participação e verdade devem orientar as atividades escolares. Concursos literários sobre moral e civismo são ótimos recursos didáticos. (p. 105) Caberia à disciplina História auxiliar a Educação Moral Cívica no cumprimento dos objetivos estipulados. No âmbito do ensino de $1^{\circ}$ grau, faz parte do conteúdo programático: "Admiração pelos bons exemplos. Visitas e excursões. Estudos de valores como o sacrifício, o esforço, a justiça, os deveres e o amor à Pátria” (p. 112). Para Durkheim, no livro A Educação Moral, do ponto de vista da moralização infantil, o ensino das ciências da natureza possui uma virtude propedêutica incontestável, enquanto o ensino da arte tem um papel meramente defensivo, moralizador por excelência é o ensino da realidade social, principal objeto da atividade moral. Contudo, a ciência dos fatos sociais seria ainda muito rudimentar para poder ser ensinada na escola, mas a história, "parente próxima da sociologia”, desde que bem ministrada e compreendida, poderia dar às crianças a idéia do que é a sociedade e das suas relações com o indivíduo. No entanto, a história não poderia ser ministrada de modo a reiterar o preconceito de que a sociedade é obra de alguns indivíduos, mas de modo a afirmar que a sociedade possui uma natureza que se impõe aos indivíduos - e a todos. $\mathrm{O}$ que mais impressionará os alunos no sentido moralizador será fazê-los compreender a história como um destino: em cada século, continua a obra dos antepassados. A vida social sempre avança, apesar dos indivíduos, por intermédio dos quais esta evolução se realiza, renovarem-se incessantemente. A história bem ministrada e compreendida silencia as rupturas, os conflitos, porque nega a morte, a finitude, a utopia e o desconhecido. Assim, "a criança, e mais tarde o homem, compreenderá que os direitos que são reconhecidos 
atualmente, a liberdade que desfrutamos, a dignidade moral atribuída a ela, tudo isso é uma obra não de determinados indivíduos, de tal ou qual geração, mas desse ser, a um só tempo pessoal e impessoal, que chamamos de França, ou seja, compreenderá que foi a sociedade inteira, desde suas origens mais remotas, que preparou sua emancipação” (op. cit., p. 267).

As atividades extra-classe também consistiam em oportunidades importantes para favorecer a formação moral e social. E o centro cívico auxiliaria na preparação das comemorações das datas pátrias. Para Nérici, o ensino de $2^{\circ}$ grau seria destinado a adolescentes cujas preocupações maiores seriam, entre outras, o "amor, com vistas a um possível casamento, trabalho, levado a efeito por meio de uma profissão”. (p. 129). É importante observar que o casamento e a formação da família eram itens que precisavam ser trabalhados na escola para que fossem almejados pelos alunos. As idéias que já começavam a circular no país neste momento, que valorizavam a liberdade sexual e o "amor livre", abalavam a moral e os "bons costumes". Algumas publicações também eram consideradas uma ameaça à juventude: "a pornografia é constantemente prejudicial se não está constantemente ligada à uma constante disciplina e a um vigoroso domínio de si mesmo e, sobretudo, ao uso das forças sobrenaturais da oração e dos sacramentos. As armas de sedução da imoralidade também estão na arte, na moda e nos costumes públicos e privados" (BUZAID, 1970, p. 38). Assim, seria preciso "desenvolver com maior ênfase os valores sócio-morais. Orientar para a coerência de comportamento e respeito ao próximo. Levar a compreender melhor a instituição 'família'. Predispor para a constituição da família”. (p. 132) Apesar de citar John Dewey sobre a importância de socializar o educando, defendendo que a socialização não é a estandardização, a padronização do comportamento, porque a "socialização quer dizer tomada de consciência por parte do indivíduo dos seus deveres para com os semelhantes e das necessidades coletivas; porém, o ensino renovado deve se esforçar pela individualização do educando". (p. 36) é possível observar que as orientações são dadas no sentido de desenvolver um comportamento social responsável para com a comunidade (p. 84), mas também bastante normatizado.

Dentre todos os manuais pedagógicos examinados, o livro Didática e prática de ensino, escrito por José de Arruda Penteado, publicado em 1979 é aquele que menos traz referências quanto ao ensino da disciplina Educação Moral e Cívica e o tratamento dos valores morais na escola. No entanto, ele cita John Dewey quando faz referência à passagem da moral do dever para a moral da cooperação. A justificativa militar para 
transformar a formação moral em disciplina obrigatória e em prática educativa era levar o educando a adquirir hábitos morais e cívicos, através da consciência de princípios e do desenvolvimento da vontade, para a prática de atos que o fizessem útil à comunidade. A prática conseqüente dos atos morais e cívicos era buscar condicionamentos considerados sadios e estabelecer hábitos desejados. O "fortalecimento da vontade" levaria à formação do caráter e este daria origem ao comportamento "do homem moral e do homem cívico". De acordo com as Prescrições sobre currículos e programas de Educação Moral e Cívica nos três níveis de ensino (Art. $4^{\circ}$ do Decreto-Lei 869/69), o conceito de civismo deveria ter em vista três aspectos fundamentais: caráter, patriotismo e ação. "Caráter - com base na moral, originária da ética, tendo por fonte Deus (Constituição do Brasil, Preâmbulo). Amor à Pátria - e às suas tradições, com capacidade de renúncia. Ação intensa e permanente em benefício do Brasil." (p. 15) Desta forma, constituída como um recinto ao abrigo das desordens e das tentações do mundo exterior, a escola formaria o cidadão que deveria contribuir para a formação de uma pátria ordeira e progressista. A luta contra os "elementos exteriores", sempre suspeitos de introduzir na escola a desordem, são as marcas de uma instituição protetora que tem por objetivo favorecer uma atmosfera de disciplina, de relações sociais bem reguladas e de aparente tranqüilidade.

\subsection{A ADEQUAÇÃO DAS CRIANÇAS À SOCIEDADE}

A necessidade de educar as crianças para a coletividade e integrá-las à comunidade também consiste em uma das formas de moralização praticadas na escola, que deve: "desenvolver no educando hábitos e crenças compatíveis ou impostos pelos padrões éticos

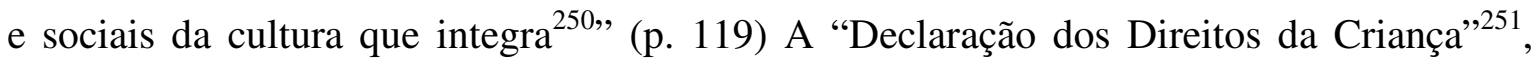
publicada em 1979, afirmava que as crianças tinham direito à educação gratuita e obrigatória, ao menos no primeiro ciclo, e que a criação de iguais oportunidades desenvolveria as aptidões, o discernimento, a responsabilidade moral e social, no sentido

\footnotetext{
${ }^{250}$ ROSAS, Paulo. "Exame psicológico de candidatas ao magistério primário de Maceió", RBEP, n 107 , jul/set. 1967, p. $111-151$.

251 “Declaração dos direitos da criança”, RBEP, no 143, jan./abr. 1979, p. 229 - 230.
} 
de torná-las um "elemento útil à sociedade". Para o professor Paulo Sá ${ }^{252}$, toda reforma do ensino não passará de "pretexto para conferências" se não for acompanhada de uma verdadeira revolução moral na qual se convença o povo de que é preciso reformar, melhorar, adequar o ensino às necessidades pedagógicas, sociais, econômicas e morais do meio em que se vive. Nise Pires ${ }^{253}$, pesquisadora do INEP, ao escrever sobre os objetivos da educação fundamental em 1971, ano de promulgação da $\mathbf{L D B} \mathbf{n}^{\mathbf{0}} \mathbf{5 . 6 9 2}$, que instaura o $1^{\text {o }}$ grau de 8 anos, afirma que a formação básica realizada no ensino fundamental, deveria promover a integração, a participação dos alunos na vida em comunidade, o que seria alcançado mediante uma "adequada formação moral e cívica". Tal formação primaria por trabalhar com valores sociais desejáveis ao relacionamento humano "adequado" e à responsabilidade cívica: "fazer o educando integrar comportamentos adequados, desenvolver capacidades ligadas ao mundo do trabalho. O educando deve receber assistência para se desenvolver, alimentos, oportunidades, para se tornar uma pessoa ajustada. Os objetivos devem visar à mudança de comportamento dos alunos” (p. 20). Lúcia Marques Pinheiro ${ }^{254}$, coordenadora da Divisão de Aperfeiçoamento do Magistério do CBPE, em 1972 também publica um artigo na RBEP no qual trata da reformulação de currículos e programas do ensino fundamental. Pinheiro chama a atenção para o papel das disciplinas na integração dos indivíduos à sociedade: as ciências humanas deveriam assegurar segurança ao educando, participação ativa na comunidade, melhorando a vida social, desenvolvendo interesse e amor pela comunidade próxima, pela cidade, pelo país, pela humanidade, independente de raças, crenças religiosas e políticas. Segundo a autora, as ciências sociais e humanas promoveriam a integração social do educando e a sua "formação moral para a cidadania", através da compreensão de valores sociais e morais, da importância da vida familiar, da valorização dos "homens que se destacam pelo bem comum" e da compreensão que todos podem contribuir à evolução social e moral do homem. Segundo Durkheim, para inculcar nas crianças os sentimentos da moralidade, é necessário estabelecer uma ligação entre elas e um grupo social. Para que o homem seja um ser moral, é necessário que ele sinta-se solidário a uma sociedade, já que a moralidade

\footnotetext{
${ }^{252}$ SÁ, Paulo (publicado inicialmente em Educação, Rio) "Relações entre a indústria e o ensino de engenharia", RBEP, nº 57, jan./mar. 1955, p. 165 - 175 .

${ }^{253}$ PIRES, Nise. “Objetivos da educação fundamental”, RBEP, No 123, jul./set. 1971, p. 10 - 24.

254 PINHEIRO, Lúcia Marques. "Bases para a reformulação de currículos e programas do ensino fundamental”, RBEP, nº 125, jan./mar. 1972, p. 10 - 31.
} 
começa onde começa a vida social e os fins coletivos são os fins morais por excelência. Ele considera que a sociedade política, a pátria, goza sobre as demais de uma verdadeira primazia. Esta entendida como necessária para a realização progressiva da idéia de humanidade. É a esta sociedade que a escola tem por função ligar especialmente a criança, porque a escola é o único meio moral que pode ensinar a criança a conhecer e a amar a pátria. É por isso que a escola, segundo o autor, tem papel tão importante na formação do país, porque é nela que a criança desenvolverá o gosto pela vida em comum e adquirirá o hábito de agir e pensar em uma coletividade. Emmanuel Carneiro Leão ${ }^{255}$, filósofo e escritor, em artigo publicado na RBEP em 1979, cita o próprio Durkheim para dizer que a educação deve desenvolver na criança estados físicos, intelectuais e morais, reclamados pela sociedade e pelo meio ao qual a criança destina-se. Exercida pelas gerações adultas sobre aquelas que ainda não estão maduras para a vida social, a educação seria a socialização da "geração nova": é pela cooperação e pela tradição sociais que o "homem se faz homem". Para Leão, toda educação tem um endereço e seu fim "não está na posse de formas e modos físicos, imaginários e simbólicos de agir, conhecer e sentir, mas na aquisição de padrões mutáveis de comportamento, que tornem mais fácil produzir aquelas formas e estes modos, sem muitas ameaças aos sistemas. A viagem da educação é sempre a viagem de sistematização do sistema“. (p. 12 - grifos meus) Na escola, as çrianças vão se adaptado à turma onde estudam, ao grupo e tem a oportunidade de passar por processo de socialização que é exterior à família. Segundo Lucy Serrano Vereza ${ }^{256}$, secretária de educação e cultura do município do Rio de Janeiro, a escola primária "socializa, 'ajusta o indivíduo ao grupo'; leva o aprendiz a comportar-se de acordo com os princípios estabelecidos naquela comunidade minúscula. Tal ação biparte-se em dois lances: um calcado na necessidade de que o aluno se torne consciente de seus direitos e deveres e reconheça os dos companheiros; noutro, constituindo-se no ato de aprender" (p. 57). Dentre as práticas adotadas pelas escolas para promover a integração das crianças à sociedade, estão projetos e comemorações cívicas. Em artigo de 1980, a socióloga Maria Lúcia Melo ${ }^{257}$, ao sugerir um "modelo experimental de cooperativismo nas escolas de $1^{\circ} \mathrm{e}$

\footnotetext{
${ }^{255}$ LEÃO, Emmanuel Carneiro. “A viagem da educação”, RBEP, no 144, mai./ago. 1979, p. 11 - 17.

${ }^{256}$ VEREZA, Lucy Serrano. (secretária de ed. e cultura do município do RJ) "Aprendizagem inicial da linguagem no ensino de $1^{\circ}$ grau", RBEP, n 144, mai./ago. 1979, p. 53 - 57.

${ }^{257}$ MÉLO, Maria Lúcia. "Modelo experimental de cooperativismo nas escolas de $1^{\circ}$ e $2^{\circ}$ graus" RBEP, $\mathrm{n}^{\circ}$ 146, jan./abr. 1980, p. $383-389$.
} 
$2^{\text {o }}$ graus", afirma que o mesmo pode levar os alunos a uma mudança de comportamento, viabilizada através do desenvolvimento de hábitos, atitudes, participação e solidariedade comunitária: o projeto deveria permitir que escola preparasse o indivíduo para a vida, de modo a integrá-lo na comunidade, pelos princípios cooperativistas da livre adesão, "indiscriminação religiosa, social e política", estimulando a aquisição de bens pelo trabalho. No que tange à formação dos professores, um artigo de Paulo Rosas ${ }^{258}$ acerca dos comportamentos das professoras primárias, identifica que a percepção que as mesmas tinham acerca de sua perspectiva social: elas acreditam que, para que fossem bemsucedidas, era preciso que contribuíssem "para o bem estar da coletividade". É importante observar que, ao relatar as qualidades e os defeitos mais apreciados pelas professoras em homens e mulheres, os predicados enunciados são os mesmos que condizem com uma postura colaborativa e compreensiva para com o outro e no sentido de preservá-lo: "mais apreciadas são as qualidades morais (honestidade, continência ou controle sexual, autenticidade, 'caráter') e as predominantemente pessoais-sociais (coragem, 'personalidade', cavalheirismo, compreensão), atingindo as duas categorias o índice de $87,5 \%$ entre as qualidades apreciadas nos homens e 88,5\% entre as apreciadas nas mulheres. Os defeitos que mais desagradam também são relacionados à conduta moral (desonestidade, falta de controle sexual, embriaguez) falta de 'caráter', mentira, hipocrisia) e os de conduta afetivo-social (egoísmo, falta de compreensão, covardia, falta de 'personalidade', ciúme), 85,7\% no homem 78,8\% na mulher. 'Ajudar os outros', 'cuidar das crianças' - crenças, que fundamentam suas atitudes em relação à profissão e, de modo mais amplo, sua percepção do mundo". (p. 143)

\subsection{A EDUCAÇÃO E A DEMOCRACIA}

Uma palavra que também foi encontrada com freqüência no momento em que os autores tratavam das práticas de moralização na escola foi a "democracia". Muitas das

\footnotetext{
${ }^{258}$ ROSAS, Paulo. "Exame psicológico de candidatas ao magistério primário de Maceió", RBEP, no 107 , jul/set. 1967, p. $111-151$.
} 
práticas defendidas nos manuais pedagógicos e nos periódicos educacionais visavam aos ideais democráticos: as escolas primárias deveriam favorecer a formação democrática da criança, o cultivo do espírito crítico e da consciência moral do educando, assegurando a compreensão do mundo social; os deveres e direitos cívicos e os ideais democráticos; desenvolvendo habilidades para o trabalho em grupo $^{259}$. Para o professor Wilson Martins $^{260}$, a educação democrática é capaz de corrigir o "horror do estandardizado, sem esmagar a personalidade de cada um, dinamizando as potencialidades. (...) $\mathrm{Na}$ ordem moral, sentimentos democráticos correspondem a liberalismo de espírito, a tolerância, ao respeito da pluralidade essencial do ser humano, à vida grupal na sua expressão mais alta $\mathrm{e}$ nobre. E correspondem, também, à ideia de igualdade social de todos os homens, o que não significa ignorar-lhes as desigualdades individuais. (...) A cooperativa é, igualmente, uma escola de moral, e, assim, a simples decisão de 'educar democraticamente' conduz-nos à conciliação automática de domínios que nos parecem tão distantes, pois a moral nos conduziu à economia, assim como a economia democrática nos remete inevitavelmente à moral". (p. 134) O educador Fernando Tude de Souza ${ }^{261}$, em artigo publicado na RBEP em 1954, dizia que a educação deveria defender e buscar implementar na vida dos alunos a tolerância e as decisões devem ser tomadas sempre com o consentimento da maioria. Para Souza, as escolas deveriam primar pela devoção à verdade porque "liberdade completa de opinião, é a essência da vida democrática. Dentro da decência e da verdade todos devem dizer o que pensam" (p. 215). Os jovens também deveriam ser "treinados na escolha certa de seus líderes".

Acerca do potencial "democratizador" das escolas, Luiz Alves de Mattos ${ }^{262}$ afirmou: "a escola primária nunca foi e a secundária há muito deixou de ser uma agência selecionadora de talentos privilegiados que se situam na cota da genialidade e da quase

\footnotetext{
${ }^{259}$ CAMPOS, Paulo de Almeida. "Seminário regional sobre planos e programas da escola primária", RBEP, no 64, out./dez. 1956, p. 73 - 93. Trata-se do "Informe Final" do "Seminário regional sobre planos e programas da escola primária", promovido em maio, no Peru, pela UNESCO e pela OEA, visando ao estudo dos problemas relativos à generalização da educação primária gratuita e obrigatória na América Latina.

${ }^{260}$ MARTINS, Wilson. "O novo Emilio (O que a educação pode esperar das ciências sociais)", RBEP, n⿳ 66 , abr./jun. 1957, p. $125-142$.

${ }^{261}$ SOUZA, Fernando Tude de. "A crise dos valores morais e os educadores" (artigo inicialmente publicado em $O$ Jornal, Rio), RBEP, nº 56, out./dez. 1954, p. 212 - 215.

${ }^{262}$ MATTOS, Luiz Alves de. (Educação, Rio) “A aprovação e a reprovação escolar”, RBEP, no 63, jul/set. 1956, p. $255-257$.
} 
genialidade. Ambas são de direito - e devem se tornar de fato - agências difusoras da educação e da cultura a serviço da juventude e da democracia. Sua alta missão social é valorizar, pela educação e pela aculturação, o imenso potencial humano da nação que jaz inaproveitado e imerso no analfabetismo e na ignorância". (p. 257) A disciplina na escola normal, instituição de formação de professores, também deveria ter um "caráter democrático, fundamentando-se no respeito à personalidade e ao desenvolvimento das possibilidades individuais. Educação cívica, espírito democrático, sentido da unidade social da nação, devem estar relacionados ao programa. Base moral consistirá na organização do regime interno das Escolas Normais"263. (p. 147) Quando Robert J. Havighurst $^{264}$, pesquisador do INEP, escreveu sobre as tarefas evolutivas das crianças e dos adolescentes, em 1957, ele afirmou que o crescimento consiste também nos "modos de proceder". As atividades de caráter social são fruto da aprendizagem proporcionada pela sociedade e a escola seria o lugar no qual seriam ensinados os conceitos de lei, governo, instituições sociais, que permitiriam aos indivíduos lidar com os problemas da democracia moderna e desenvolver um comportamento socialmente respeitável. Ao sair da escola, os adolescentes deveriam estar aptos a se tornarem membros da comunidade. $\mathrm{Na}$ escola, eles poderiam adquirir "um conjunto de valores e de um sistema ético para a orientação do comportamento. A vida civilizada é cheia de conflitos e as regras morais não abrangem pormenores de casos específicos. Procurar harmonizar a visão que tem do mundo com os valores que se propõem. Numa sociedade aristocrática, a escola secundária destina-se a dar só um certo verniz social para poucos. Na sociedade democrática e industrializada, a escola é um agente de melhoria da sociedade que encontra-se em transformação.” (p. 142) Em artigo publicado na RBEP em 1956, intitulado "Educação e progresso social”, o professor Nunes Mendonça ${ }^{265}$ citou o livro "Democracia e Educação", de John Dewey. A partir desta obra, Mendonça mencionava como objetivos da educação o desenvolvimento natural, a

\footnotetext{
263 "Seminário Interamericano de Educação Primária”, promovido pela UNESCO e pela OEA. RBEP, n 42 , abr./jun. 1951, p. $109-155$.

${ }^{264}$ HAVIGHURST, Robert J. "Tarefas evolutivas das crianças e dos adolescentes”, RBEP, no 67, jul./set. 1957, p. $130-143$.

265 MENDONÇA, Nunes. (Correio de Aracaju, Aracaju) "Educação e progresso social”, RBEP, n 62, abr./jun. 1956, p. $149-153$.
} 
eficácia social, a cultura e o "enriquecimento mental e pessoal". Nesta perspectiva, deviase buscar a "valorização da personalidade humana, aproximação do individualismo e do coletivismo numa síntese democrática. Oferecendo a todos a mesma possibilidade de desenvolver suas aptidões e escolher sua carreira, alteando o nível mental e moral do povo, a educação concorrerá para o predomínio de formas mais puras e mais elevadas de subordinação". (p. 150) O suíço Adolphe Ferrière (1879 - 1960), um dos fundadores do movimento da Escola Nova, é citado por Angel Diego Márquez ${ }^{266}$, especialista em educação da UNESCO, em artigo publicado na RBEP em 1965. Ferrière é citado pela defesa do "ensino sob medida" e pela escola renovada, que valoriza a cooperação e a liberdade com responsabilidade: "a disciplina não é repressiva, é compreensiva. Somente nesse clima pode-se atingir uma educação moral e cívica para a prática efetiva da democracia”. (p. 273) Anísio Teixeira ${ }^{267}$, que também partilhava dos ideais do movimento renovador da educação, afirmou, em artigo publicado na RBEP em 1952, que "a unidade nacional será promovida pelas escolas quando nelas prevalecer o princípio do Estado moderno, que é o de que a lei não é competente para decidir em questões de saber ou de consciência profissional. O mais perfeito esclarecimento das inteligências é o mais eficaz instrumento da unidade nacional e esse esclarecimento só pode ser conseguido no regime da liberdade democrática". (p. 35)

\subsection{A CRISE POR CONTA DA MUDANÇA DOS VALORES SOCIAIS}

Segundo Durkheim (2008), os valores na educação moral visariam os fins sociais. A sociedade condicionaria a existência individual. Primitivamente, o indivíduo não teve que valorizar seu pertencimento a um grupo social. O comportamento de cada membro

\footnotetext{
${ }^{266}$ MÁRQUEZ, Angel Diego. "Renovação didática no ensino médio", RBEP, n 100, out./dez. 1965, p. 273 $-294$.

${ }^{267}$ TEIXEIRA, Anísio. "Notas sobre a educação e a unidade nacional", RBEP, no 47, jul./set. 1952, p. 34 49.
} 
desse grupo foi estritamente regulamentado pelos tabus, pelas regras e pelos imperativos sociais cujo objetivo era a conservação e a defesa do clã, da tribo ou da comunidade. Esta moral implícita, sentida e vivida, não permitia as decisões e os atos individuais. Ela foi essencialmente restritiva. A moral primitiva foi exclusivamente social, transmitida de comunidade em comunidade, de geração em geração, pelos hábitos, pelas tradições, pelos costumes, pelos ritos e pelas práticas religiosas. Se a evolução social seria, em grande parte, emitida pelas tradições e pelos imperativos da religião, a sociedade e seus valores deveriam permanecer nos verdadeiros fins da educação moral. $\mathrm{O}$ indivíduo não poderia viver, desenvolver-se, elevar-se intelectualmente e moralmente, senão pela sociedade; as aspirações mais altas só seriam desenvolvidas por meio da existência coletiva. A concepção sociológica da educação moral exige o conhecimento da estrutura e das leis da sociedade a fim de que o indivíduo possa se submeter livremente. É nessa submissão consciente e voluntária que reside, para Durkheim, a autonomia de cada um: é para ela que ele considera possível a ascensão dos valores superiores e a mais alta elevação da personalidade. Nesse sentido ele concebeu a educação moral das novas gerações.

O educador Fernando Tude de Souza ${ }^{268}$, em artigo publicado na RBEP em 1954, afirmava que a crise dos valores morais pela qual a sociedade estava passando era resultado do "abandono" a que tinha sido deixada a "educação do povo". Segundo o autor, "é fácil sentir uma verdadeira revolução na compreensão dos valores morais. Aquele cunho espiritual que cada dia foge mais das nossas escolas, colégios e universidades, é um sinal dos tempos. O desrespeito aos valores humanos, aos valores morais, é uma consequiência imediata da falta da boa educação, pois, repitamos sempre, ser educado não é apenas saber ler e escrever ou possuir um título qualquer dado até por uma universidade. Ser educado é algo de muito nobre e elevado. E nossas escolas só mesmo por milagre conseguem educar..."(p. 213) Como solução para a "crise" a qual referiu-se, Souza defendia que educação "implantasse" valores "espirituais e morais" na vida dos cidadãos, tais como tolerância, fraternidade, "devoção à verdade": "os valores morais tem consequiências principalmente nas relações sociais. Os valores espirituais tem efeito em termos de emoções e sentimentos profundos. O espírito criador deve ser estimulado, as artes e as letras oferecem oportunidades excepcionais. A boa escola não se limita ao trabalho

${ }^{268}$ SOUZA, Fernando Tude de. (O Jornal, Rio) "A crise dos valores morais e os educadores" RBEP, $\mathrm{n}^{\circ}$ 56, out./dez. 1954 , p. $212-215$. 
sistemático da instrução. O momento difícil chega agora ao Brasil e é propício para um exame". (p. 215) O artigo de Abgar Renault ${ }^{269}$, professor universitário, publicado na RBEP em 1955, vai ao encontro do texto de Souza, por chamar a atenção para a mudança nos valores morais, considerada bastante negativa para ambos os autores. Renault afirmava que os professores nunca haviam sido tão necessários quanto naquele momento, por conta das pessoas estarem vivendo em um "mundo convulso". O termo empregado pelo autor corresponde à idéia de que os valores morais estavam em constante mutação devido às mudanças sociais e econômicas que estavam ocorrendo, desencadeadas principalmente pela industrialização e pela expansão dos meios de comunicação. Segundo o autor, "as tábuas de valores pela qual aferíamos as coisas do mundo moral e intelectual foram quebradas. Perdemos aquele nobre sentido da direção que os valores tradicionais simbolizavam e transmitiam”. (p. 235) Renault defendia que, naquele momento em que os valores morais estavam ameaçados, o ensino "por si só" não bastaria, seria preciso que as escolas desenvolvessem, nos alunos, princípios mentais e éticos que tornariam mais fáceis, porque orientadas previamente, as escolhas que os indivíduos teriam de fazer em sua vida social.

A transmissão e a perpetuação dos valores morais também auxiliavam na tradição e na manutenção dos costumes da sociedade. Fernando de Azevedo ${ }^{270}$, em artigo publicado na RBEP em 1955, afirmava que há uma interdependência entre os valores e as técnicas que cada sociedade se esforça por transmitir, os meios utilizados para esse fim e as condições histórico-sociais em que se realiza esse processo de transmissão. Citando Durkheim, Azevedo dizia: "cada sociedade, considerada em momento determinado de seu desenvolvimento, possui um sistema de educação que se impõe aos indivíduos de modo irresistível. É ilusão acreditar que podemos educar nossos filhos como queremos. Há costumes com que somos obrigados a conformar-nos." (p. 244) Neste artigo, o autor discutia até que ponto seria possível considerar a liberdade como alguma coisa inerente ou

\footnotetext{
${ }^{269}$ RENAULT, Abgar. (publicado inicialmente no "Mensageiro Rural", Minas Gerais) "A professora rural e o cumprimento de sua missão", o texto é um discurso que foi proferido pelo paraninfo da $2^{\mathrm{a}}$ turma da Escola Normal Rural “A. S. Azevedo”, de Minas Gerais, RBEP, nº 60, out./dez. 1955, p. 235 - 243.

${ }^{270}$ AZEVEDO, Fernando de. "Educação e liberdade" (publicado inicialmente no jornal O Estado de S. Paulo) RBEP, nº 60, out./dez. 1955, p. $243-249$.
} 
imanente ao processo educacional ou se seria possível conduzir esse processo sem comprometer a liberdade do educando.

\subsection{A EDUCAÇÃO E A LIBERDADE: “TODA VERDADEIRA LIBERDADE É DISCIPLINA DE SI MESMO"}

A moral e a liberdade caminhavam juntas, mesmo que a expansão de uma implicasse na minimização da outra. Assim como ocorre no processo educativo, a moralização das pessoas requer a diminuição de sua liberdade e uma maior sujeição ou adesão dos mesmos: sujeita-se a si próprio, em prol dos outros, do bem-estar da coletividade. Desta forma, a coletividade exige, em troca de suas solicitudes, uma submissão sempre maior do indivíduo e uma restrição na área da "liberdade". Fernando de Azevedo $^{271}$, em artigo publicado na RBEP em 1955, intitulado "Educação e liberdade", dizia que a educação consistia na transmissão de uma civilização, numa pressão que os adultos exerciam sobre os mais jovens, a fim de que estes realizassem o ideal humano que os adultos traziam consigo. Tratar-se-ia de um processo que seria realizado entre gerações, pela pressão de uma que já estivesse formada e pela resistência outra que estaria em formação. Azevedo citou o educador americano John L. Childs (1889-1985), que afirmava que neutralidade social ou moral em educação não passariam de conceitos contraditórios. Toda educação estaria planejada de modo a converter o educando em algo que não seria se ele ficasse a mercê das próprias forças ou das influências do ambiente. Assim, haveria sempre uma imposição de idéias, de crenças e de normas de vida, variáveis de uma sociedade a outra e de uma para outra fase de evolução social da humanidade. Para o autor brasileiro, nas flutuações ou nas tendências dos regimes políticos, o Estado ora favorecia, ora sacrificava o princípio da liberdade. Contudo, em sua concepção, ela seria uma conquista de todos os dias. A questão da liberdade também é tocada pelo relatório ${ }^{272}$

\footnotetext{
271 AZEVEDO, Fernando de. "Educação e liberdade" (publicado inicialmente no jornal O Estado de S. Paulo) RBEP, n $^{\text {0 } 60, ~ o u t . / d e z . ~ 1955, ~ p . ~} 243-249$.

272 “A formação de professores" Trata-se do relatório apresentado na Conferência das Escolas para a Compreensão Internacional, em colaboração com a UNESCO, em 1955. RBEP, nº 64, out./dez. 1956, p. 141 -179 .
} 
apresentado na Conferência das Escolas para a Compreensão Internacional, em colaboração com a UNESCO, em 1955, que foi publicado na RBEP em 1956. O texto dizia que apenas os alunos que viessem de escolas onde reinava a justiça, seriam capazes de lidar com a liberdade, diferentemente daqueles que eram originários de ambientes repressivos.

É possível perceber nos discursos presentes tanto nos manuais pedagógicos quanto nos periódicos educacionais, a influência das idéias trazidas pelo movimento da Escola Nova, nas quais o aluno é considerado como indivíduo no processo educativo. Afro do Amaral do Fontoura, por exemplo, no livro Didática Geral, reeditado em 1965, sugeria que a educação moral deveria "exercitar-se de dentro para fora, pela experiência e pela prática gradual do sentido crítico e da liberdade" (p. 131). Citando a educadora italiana Maria Montessori, ele dizia que "sem liberdade não pode haver desenvolvimento da personalidade". (p. 117) Teobaldo Miranda Santos, no livro Metodologia do ensino primário, reeditado em 1955, afirmava que a autoridade docente teria um "indiscutível valor moral" (p. 20). Dentre os "objetivos da aula", estaria a aquisição de hábitos e formação de atitudes. Para tanto, o autor dizia que a "repetição constante de um ato determina a formação de um hábito" (p. 59). É curioso observar que, ao mesmo tempo em que Santos evoca elementos derivados da teoria behaviorista para conduzir e controlar o comportamento das crianças, ele cita autores e propostas de trabalho que partilham os ideais da educação renovada. Agrupar os alunos em classes homogêneas, por exemplo, de acordo com o autor, seria uma "necessidade imposta pelas diferenças das crianças" (p. 71). Assim como fez Fontoura, Santos também citou Montessori, defendendo que a disciplina deveria ser "imposta pela própria criança a si mesma, graças ao interesse despertado pelo trabalho escolar; ela deve conseguir o domínio de si mesma" (p. 95). Ao citar o método de Winnetka, Santos defende a importância da auto-correção no processo de aprendizagem, no qual cada um deveria "verificar e controlar o próprio trabalho" (p. 111). Afirmando que as escolas novas trabalham com o autogoverno e com "autodeterminação", o autor dizia que as crianças só conquistariam sua liberdade quando conseguissem dominar, "pela disciplina interior, os próprios instintos. Toda verdadeira liberdade é disciplina de si mesmo" (p. 128 - grifos meus). Aldo Perracini, no livro A escola renovada, publicado em 1972, também defendia que cabia à educação escolar incutir nos alunos "conscientização, 
liberdade madura, autodisciplina, diálogo" para o "bem estar do indivíduo e da sociedade" (p. 61). No final dos anos de 1970, os autores dos manuais pedagógicos continuaram a evocar em seus livros a contribuição da Escola Nova quando tratavam da questão da liberdade dos educandos. Romanda Gonçalves, em Didática Geral, na reedição de 1977, afirmava que "a educação não pode nem deve inibir a reação do educando, quer no plano físico, quer no plano moral; contudo, não se deve permitir que o educando 'faça o que quer' e sim 'aquilo que pode fazer'. (...) A liberdade não é exagerada, ilimitada, é uma 'liberdade dirigida', consciente, a única capaz de conduzir o educando à autodisciplina, isto é, à capacidade de dominar, pela disciplina interior, suas tendências instintivas" (p. 62 - grifos meus). Levar cada um a cuidar de si, a controlar a si próprio, a conter os próprios instintos e a fazer uso racional da liberdade são características que foram trazidas pelo discurso da Escola Nova e que foram evocadas pelos autores para justificar a promoção de práticas de moralização na escola.

\subsection{A ESCOLA COMO UMA "SOCIEDADE EM MINIATURA"}

A idéia da escola enquanto um lugar que representasse e reproduzisse a sociedade também esteve presente nos textos que faziam referência à moralização dos indivíduos. Segundo o professor universitário Abgar Renault ${ }^{273}$, em artigo publicado na RBEP em 1955, a educação lida com “formas em vias de ser”. Na escola, “a professora deve encorajar o espírito de colaboração nos alunos, enriquecendo o convívio escolar, que deve revestir-se dos caracteres totais da vida social". (p. 242) Em artigo publicado no mesmo periódico, no ano de 1957, o professor Wilson Martins ${ }^{274}$, ao discutir sobre a socialização realizada no ambiente escolar, citou Fernando de Azevedo para afirmar que as escolas deveriam ser reorganizadas nos moldes de uma "sociedade em miniatura", de modo que permitissem a participação direta na vida social, colaborando com todos os interesses da

\footnotetext{
${ }^{273}$ RENAULT, Abgar. (publicado inicialmente no "Mensageiro Rural", Minas Gerais) "A professora rural e o cumprimento de sua missão", o texto é um discurso que foi proferido pelo paraninfo da $2^{\mathrm{a}}$ turma da Escola Normal Rural “A. S. Azevedo”, de Minas Gerais, RBEP, nº 60, out./dez. 1955, p. 235 - 243.

${ }^{274}$ MARTINS, Wilson. "O novo Emilio (O que a educação pode esperar das ciências sociais)" RBEP, n ${ }^{\circ}$ 66, abr./jun. 1957, p. $125-142$.
} 
comunidade. Seria preciso também incutir hábitos de higiene nas crianças, formando-as na "religião da higidez": "pela experiência, das vantagens dessa formação, a criança será, por sua vez, a educadora da sua família, do seu meio habitual.” (p. 131) Martins sugeria também que os alunos participassem na administração das escolas e que estas fossem remodeladas nas bases de uma comunidade de autogoverno, na quais houvesse coresponsabilidade de mestres e alunos. Lourenço Filho $^{275}$, em artigo publicado na RBEP em 1961, a propósito do centenário de John Dewey, afirmava que, segundo o autor, não deveria haver separação entre "vida e educação", por isso a escola deveria ser uma comunidade em miniatura, estando conectada com as organizações da vida cívica, religiosa, econômica e política. A filosofia deveria ser tomada como método de reflexão e como hipótese geral para o ajustamento social. Em relação à moralização dos indivíduos, Lourenço Filho citou Dewey ao afirmar que "há algumas gerações, o grande obstáculo da reforma do ensino provinha da crença muito disseminada da eficácia quase mágica da cultura do espírito. Hoje, é a eficácia das coisas, como coisas, que embaraça o caminho. Pensar é o único modo para fugir ao impulso cego e à rotina. $\underline{\mathrm{O} \text { homem privado de }}$ pensamento não é senão dominado por instintos e apetites...” (p. 162 - 163 - grifos meus) As pessoas seriam livres na medida em que agissem sabendo o que poderiam obter, sem desprezar os valores sociais e morais: "mais educação significa maior capacidade de pensar e decidir com convicção" (p. 164).

As idéias de Dewey, dentre as quais está a concepção da escola como uma "sociedade em miniatura", visando à integração das crianças à vida social, como se o cotidiano escolar proporcionasse um ensaio ao ingresso no mundo adulto, foram incorporadas pelos discursos dos pioneiros da Escola Nova, cujos principais nomes são Anísio Teixeira, Lourenço Filho e Fernando Azevedo, que as trouxeram para o Brasil com o Manifesto dos Pioneiros da Educação Nova, publicado no ano de 1932. No que diz respeito à escola enquanto uma "sociedade em miniatura", tal questão foi incorporada pelos autores de alguns manuais pedagógicos brasileiros, que continuaram a defendê-la ao longo de várias décadas após a publicação do referido documento: tal concepção esteve

\footnotetext{
${ }^{275}$ LOURENÇO FILHO “A propósito do centenário de John Dewey” RBEP, nº 82, abr./jun. 1961, p. 157 164.
} 
presente em três dos manuais pedagógicos examinados para esta pesquisa, com edições que compreendem o período entre o início dos anos de 1950 ao final dos anos de 1970.

Afro do Amaral Fontoura, no livro Fundamentos da Educação, reeditado em 1954, afirmava que segundo Dewey, "a escola deve ser uma sociedade em miniatura" (p. 107). O mesmo autor, em outro título, Didática Geral, na reedição de 1965, dizia que a Escola Nova procurava preparar o aluno para a vida, por isso Dewey defendia que as instituições escolares fossem organizadas como sociedades em "miniatura". (p. 121) Em 1971, o decreto $\mathbf{n}^{\mathbf{0}} \mathbf{6 8 0 6 5}^{276}$, de 14 de janeiro de 1971, que regulamentava o decreto-lei $\mathbf{n}^{\mathbf{o}}$ 869, que dispunha sobre a inclusão da Educação Moral e Cívica como disciplina obrigatória em todos os graus e sistemas de ensino do país, também continha a referida expressão ao dizer que a escola deveria ser uma sociedade democrática em miniatura. Romanda Gonçalves, no livro Didática Geral, reeditado em 1977, também enuncia o princípio da sociabilidade tratado por Dewey, no qual a escola, como uma "sociedade em miniatura" (p. 80), deveria promover a adaptação dos alunos à vida social. Dewey preocupava-se em relacionar a vida extra-escolar infantil com a escolar, de modo a promover um ensino que correspondesse ao programa escolar, mas que trouxesse experiências e ocupações diárias dos alunos, com atenção ao desenvolvimento de cada um, assim como a disposição para a colaboração no trabalho em grupo. Desta forma, as escolas deveriam constituir-se em "sociedades em miniatura", as quais teriam a missão de "reproduzir" ao mesmo tempo em que preparassem as crianças para a vida social extraescolar. A escola, nesta perspectiva, deveria promover atividades e experiência educativas que fizessem parte da vida exterior ao ambiente escolar e, com isso, formassem este para uma atuação efetiva na sociedade em que se vivia.

Dewey, que elaborou a proposição de modelos explicativos sobre a vida, a moral e o conhecimento $^{277}$, concebia este último e o seu desenvolvimento como um processo

\footnotetext{
${ }^{276}$ Decreto no $^{6} 68065$ - de 14 de janeiro de 1971. Regulamenta o Decreto-lei no 869 , de 12-9-1969, que dispõe sobre a inclusão da Educação Moral e Cívica, como disciplina obrigatória, nas escolas de todos os graus e modalidades dos sistemas de ensino no País, e dá outras providências. RBEP, nº 122, abr./jun. 1971, p. 365 375.

${ }^{277}$ Acerca da obra do autor, podemos destacar DEWEY, J. Teoria da vida moral São Paulo: Ibrasa, 1960, DEWEY, J. Vida e educação São Paulo: Nacional, 1959, DEWEY, J. Democracia e educação: introdução à filosofia da educação São Paulo: Companhia Editora Nacional, 1959.
} 
social, integrando os conceitos de sociedade e de indivíduo. O autor apresentou uma visão do indivíduo na qual este seria moldado pelo meio a partir de suas características específicas para que alcançasse sua adaptação ao ambiente em que vivia de forma ativa pois, segundo o autor, a pessoa se adequaria conforme as necessidades para a vida naquele meio, ou seja, o ser seria "modelado" mediante a sua interação com o meio. A escola organizada como uma "sociedade em miniatura", incentivando tanto o trabalho em grupo, quanto o dever do trabalho individual para garantir o bem-estar de todos, despertaria em o sentimento de solidariedade através do cumprimento das responsabilidades de cada um para o bom funcionamento de sua comunidade. Para ele, era muito importante que a educação não se restringisse ao ensino do conhecimento por si só, como algo acabado, pois os saberes adquiridos pelo estudante, associados à experiência, deveriam ser integrados à sua vida como cidadão. Pelo que diziam os autores dos manuais pedagógicos, as escolas enquanto "miniaturas" da sociedade poderiam despertar o sentimento de responsabilidade e disciplina social. Esses modelos escolares, como o da escola como uma sociedade em miniatura reproduzia as regras morais da sociedade, visando, entre outras, a cooperação e a solidariedade. Além disso, tais configurações consistiriam também em modalidades essenciais para a organização de uma educação popular voltada para o desenvolvimento da sociedade industrial.

\subsection{A MORALIZAÇÃO E A EDUCAÇÃO MORAL E CÍVICA}

Apesar de estar presente nos mais diversos momentos e espaços da vida escolar, pelo viés de uma disciplina específica a moralização dos indivíduos poderia atender pelo nome de educação moral e cívica. As instruções oficiais ora empregavam o termo "instrução moral e cívica", ora empregavam o termo "educação moral e cívica". Na escola primária, não seria possível conformar moralmente os indivíduos mediante apenas a exposição de uma teoria dos deveres, e em qualquer que fosse o nível considerado, a moral não teria significação senão em relação à ação. Ela deveria ser essencialmente uma prática. A lição de moral por si só seria ineficaz, incapaz de dar a aluno uma formação moral e de conduzir as crianças ao exercício reflexivo da moral: ela precisaria estar associada a outras 
práticas. A mudança no comportamento das crianças seria resultado do acordo da consciência com a conduta, tendo em vista a promoção, a manutenção e a elevação dos valores morais. Isso não poderia ser fruto apenas do ensino: implicaria que a educação moral não deveria ter lugar somente, nem mesmo essencialmente, ao curso de um único espaço determinado, ela ocorreria durante toda a permanência na classe, durante as lições e as recreações, durante todas as atividades e, por conseqüência, também fora da escola. A moral não deveria ser um ponto a ser ensinado nem preenchido, mas sim, conscientemente praticado. Seria como se a referida disciplina, para ser efetivada, precisasse levar à ação. Em relação à educação cívica, ela deveria abordar os direitos e deveres dos cidadãos, o funcionamento das instituições, o sentido do Estado, da justiça, da organização política e social.

No livro Fundamentos da Educação, reeditado em 1954, Afro do Amaral Fontoura orientava os professores acerca da forma como deveria ser ministrada a Educação Moral e Cívica. De acordo com o autor, os objetivos específicos desta disciplina seriam: desenvolver as qualidades morais, o amor à verdade, a honestidade, a solidariedade, o respeito às instituições pátrias e à sociedade. Para melhor conduzir a aprendizagem desta matéria, os docentes deveriam sempre aproveitar situações reais da vida diária. As instituições escolares seriam "o melhor instrumento para a aprendizagem da educação moral e cívica. (biblioteca, pelotão de saúde, grêmio, centro cívico)" (p. 219). Em

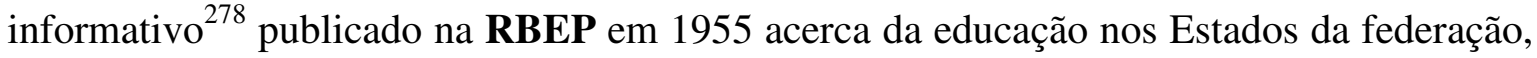
aquele referente a São Paulo dizia que, em reunião realizada em 29/11/1954, no auditório da Biblioteca Central Pedagógica "Embaixador Macedo Soares" foi debatido um plano de socialização da escola, sob a presidência do secretário de educação José de Moura Rezende. Tal plano previa a difusão da arte musical, a discussão de temas relacionados aos problemas nacionais e sugeria dedicação particular à educação moral e cívica de crianças e adolescentes. Carlos Pasquale, diretor do departamento nacional de educação, falava sobre a necessidade da educação moral e cívica para a formação das novas gerações, "extinguindo-se o ensino livresco para a formação verdadeira do homem" (p. 143). No evento também foram propostas mudanças no programa de disciplinas do curso ginasial porque, de acordo com o texto, como estava não formava, mas apenas "instruía” (p. 143). Carlos Mascaro, então diretor-substituto do departamento de educação, salientava que

278 “São Paulo” RBEP, no 57, jan./mar. 1955, p. 143 - 144. 
fosse desenvolvido um programa de educação cívica: "cogitamos de encarar a educação cívica dessa mocidade, que está a exigir ação mais enérgica dos poderes públicos, posto que há necessidade de se cuidar com mais carinho e atenção da educação cívica da criança." (p. 144) Neste mesmo número da RBEP, Sólon Borges dos Reis ${ }^{279}$ dizia em artigo que a educação moral e cívica deveria ser transmitida "pelo contágio, por aqueles que estão realmente possuídos de um ideal" (p. 176). Defendendo o caráter prático da educação moral, afirmava que "os gestos repousam sobre uma pedra angular - a emoção. Eis aí o veículo ideal da educação, que ainda mais se presta quando a educação é considerada sob o aspecto moral, que é fundamental, e o cívico, que se conjuga com ele". (p. 176) Se os gestos repousam sobre a emoção, é a ela que deverá ser dirigida a educação moral, a fim de agir como um motor que impulsiona as atitudes. O professor Jair Augusto de Oliveira ${ }^{280}$, em artigo publicado na RP em 1960, também chamava a atenção para a importância do desenvolvimento de atitudes mentais e morais na escola. Os professores teriam a "missão de imprimir cores em carne e espírito nos alunos", promovendo a integração harmoniosa das crianças na comunidade, fornecendo a elas elementos para que se tornassem elas próprias fatores de "progresso individual e social" (p. 39). Além disso, segundo Oliveira, a educação moral, social e cívica deveria promover a aquisição de bons hábitos, o entendimento acerca da organização política e da constituição da república, dos deveres do cidadão, do trabalho, da contribuição para o progresso nacional e dos símbolos da pátria.

Em artigo publicado na RP em 1962, Agostinho Minicucci ${ }^{281}$, professor do ensino normal, afirmava que seriam atribuições do Gabinete da Educação, segundo seu regimento: "levar o aluno à compreensão dos mais altos valores da vida social; acentuar e elevar na formação espiritual dos adolescentes, o amor pelos grandes feitos da História da Pátria, bem como pelos ideais da Nação Brasileira; realizar tudo quanto possa auxiliar o desenvolvimento moral do aluno" (p. 33). Além disso, a função docente, de ministrar a educação moral e cívica, poderia ser atribuída ao orientador de educação: "como prática formativa, em se tratando de matéria formativa, sem problemas de notas, como a educação

\footnotetext{
${ }^{279}$ REIS, Sólon Borges dos. (Inicialmente publicado no Correio Paulistano, São Paulo). "Educação moral e cívica na escola secundária" RBEP, nº 57, jan./mar. 1955, p. 176 - 178.

${ }^{280}$ OLIVEIRA, Jair Augusto de. "O programa do $4^{\circ}$ ano primário fundamental e a divisão pelos meses letivo do ano - outras considerações oportunas" RP, abr./1960, p. 36 - 40.

${ }^{281}$ MINICUCCI, Agostinho. “A orientação educacional e diretrizes e bases”, RP, Jun./Jul., 1962, p. 33 - 34.
} 
física e a educação doméstica, poderá o orientador desenvolver atividades que visem à formação moral e cívica do jovem” (p. 34). Assim como a educação moral e cívica, a organização social e política do Brasil também era uma disciplina que visava à moralização dos indivíduos. A professora primária Cleide Oliveira Orsi ${ }^{282}$, em artigo publicado na RP em 1965, dizia que tal disciplina tinha por objetivo a formação do "bom cidadão". Defendendo que ela deveria constituir-se como uma das disciplinas obrigatórias do currículo na escola secundária, Orsi sugeria que a mesma fosse "entregue a um professor competente, com formação reconhecidamente democrática e de moral social impecável, e ainda com habilidade tecnológica, consideramos a disciplina como um sustentáculo das instituições democráticas que o Brasil tem tentado salvaguardar.” (p. 17) Para a autora, seria preciso ensinar aos alunos desde as primeiras séries com exemplos reais, concretos, próximos às instituições que mais perto estariam dos indivíduos, aplicando o "método intuitivo, ativo, concreto, objetivo": "a família, a escola, a Igreja, o Governo do Município; em seguida, instituições mais complexas como o Estado, a Nação, a Pátria; e como últimas noções, porque mais complexas, abstratas e ideológicas, a Democracia, a República, a Constituição, etc" (p. 17).

Publicado em 1963 na RP, o artigo do professor Olivio de Araújo ${ }^{283}$ destacava a educação moral e cívica por acreditar que esta matéria seria a única que conduziria as crianças à compreensão e ao discernimento entre o bem e o mal. Enquanto prática, ao ser ministrada, a disciplina deveria apresentar fatos históricos e figuras dignas de serem imitadas. Ao citar Platão, o autor dizia que era preciso "dar virtude ao homem” (p. 32). Para a matéria, havia motivos nas aulas de história pátria e de geografia que deveriam ser explorados, levando os alunos a compreenderem os deveres para com a pátria. As festas também não deveriam ser dispensadas. Para a cultura moral, seria preciso desenvolver nos alunos o uso da liberdade com responsabilidade. Além disso, "o uso de histórias, fábulas e provérbios é indispensável para o desenvolvimento da Educação Moral e Cívica" (p. 32). Leonidas Paiva ${ }^{284}$, educador e comissário de menores, em artigo publicado na mesma

${ }^{282}$ ORSI, Cleide Oliveira. "Organização social e política do Brasil na escola secundária”, RP, Mai., 1965, p. 17.

\footnotetext{
${ }^{283}$ ARAÚJO, Olivio de. "Instrução moral e cívica”, RP, Jan./Mar., 1963, p. 32.

${ }^{284}$ PAIVA, Leonidas. "Educação moral e cívica”, RP, Mai., 1964, p. 4.
} 
revista no ano seguinte, defendia a educação moral e cívica ao lembrar que, a cada dia mais, a formação da consciência patriótica reclamava a formação na escola. De acordo com o autor, a disciplina compreenderia uma parte informativa - instrução - e outra formativa - desenvolvimento e prática das virtudes morais e cívicas. Na parte formativa seria realizada a formação do caráter e o cultivo das qualidades do "bom cidadão": "far-seá em qualquer momento, através, de todas as atividades escolares. O seu programa não está contido apenas na parte formal da Educação Cívica, mas também difundido nos programas das demais disciplinas do curso" (p. 4 - grifos meus). Para Paiva, a educação atua sobre a conduta para "modelar o caráter": "é necessário deixar manifestar-se a natureza infantil para que, conhecendo-a, o professor possa conduzi-la desenvolvendo o que nela há de bom e reprimindo o que há de mau; dar à criança ocasiões várias de agir para que ela sinta a satisfação do bem ou o desconforto do mal; oportunidades para discernir entre o que é ser corajoso ou fraco, leal ou desleal, honesto ou não" (p. 4) A escola deveria formar hábitos e atitudes, incutindo e cultivando virtudes cívicas, mostrando o valor da cooperação e da solidariedade para o progresso do país. O civismo seria visto em duplo sentido: como qualidades necessárias ao bom cidadão e no amor à Pátria. Para tanto, os alunos deveriam assumir pequenas responsabilidades na vida escolar que o levariam a assumir mais tarde responsabilidades relativas "aos encargos da vida cívica: retidão, honestidade, obediência, perseverança, coragem, ordem, trabalho, controle próprio, etc" (p. 4). As comemorações de caráter cívico, como as homenagens aos vultos nacionais, os estudos dos fatos históricos, as excursões, as festas nacionais, os hinos, as canções patrióticas e as poesias também auxiliariam na formação prática das virtudes morais. A parte informativa seria realizada mediante o estudo do programa de instrução cívica. O conhecimento dos direitos e dos deveres "esclareceria” a ação: "a ação requer prática, exercício em ocasião específica para a formação de hábitos. $\underline{\mathrm{O} \text { ensino formal falha quando os hábitos não forem adquiridos. }}$ Levar o aluno a agir em conformidade com os conhecimentos ensinados na disciplina" (p. 4 - grifos meus) O professor Walther Barioni ${ }^{285}$, em artigo publicado na RP em 1963, acerca do ensino normal em São Paulo e a Lei de Diretrizes e Bases, apresentava o currículo deste curso em 1957 e naquele momento. Neste curso de formação de professores primários, em 1957 a disciplina atendia pelo nome de "Educação Social e Cívica", já em

\footnotetext{
${ }^{285}$ BARIONI, Walther. "O ensino normal de São Paulo e a Lei de Diretrizes e Bases”, RP, Abr./Jun., 1963, p. $7-8$.
} 
1963, após a promulgação da LDB, ela atendia por "Educação Cívica". De acordo com parecer $^{286}$ do Conselho Federal de Educação referente à Educação Moral e Cívica, publicado na RBEP em 1964, a formação oferecida pela disciplina seria objeto de escolas de todos os graus. A disciplina Organização Social e Política Brasileira, por sua vez, teria "pontos de contato" com a antiga Instrução Moral e Cívica. O parecer também apresentou algumas sugestões que deveriam ser trabalhadas no âmbito do exercício da Educação Moral e Cívica nas escolas: "amor à tradição, exercício à faculdade do ensino religioso, sentido da unidade nacional; intercâmbio com instituições externas credenciadas, de caráter ético, cívico ou religioso; utilização do ensino de música na prática de hinos, canções e composições regionais e das oportunidades esportivas” (p. 117).

Em 1971, o decreto $\mathbf{n}^{\mathbf{0}} \mathbf{6 8 0 6 5}^{287}$, de 14 de janeiro, que regulamentava o decreto-lei n' 869, de 12 de setembro de 1969, dispunha sobre a inclusão da Educação Moral e Cívica, como disciplina obrigatória, nas escolas de todos os graus e modalidades dos sistemas de ensino no Brasil. Tal regulamentação incluía não apenas os cursos de formação de professores no âmbito da escola normal e, em seguida, do curso magistério, mas também compreendia a formação universitária. A disciplina visaria à formação do caráter do brasileiro e ao seu preparo para o exercício da cidadania democrática, com o fortalecimento dos valores morais da nacionalidade. De acordo com o decreto, a educação moral e cívica deveria apoiar-se nas tradições nacionais, e fortalecê-las, e mediante o culto à pátria e às instituições, o aprimoramento do caráter, a dedicação à família e à comunidade. Entre as suas finalidades, estaria a "defesa do princípio democrático, através da preservação do espírito religioso, da dignidade da pessoa humana e do amor à liberdade com responsabilidade, sob a inspiração de Deus" e a "preservação dos valores espirituais e éticos da nacionalidade". A fixação do número de horas da disciplina caberia a cada escola. A disciplina Organização Social e Política do Brasil (OSPB), obrigatória ao ensino médio, deveria articular-se à Educação Moral e Cívica. No ensino superior, inclusive na pósgraduação, ela seria ministrada como Estudos de Problemas Brasileiros. Para cuidar das

\footnotetext{
286 "Conselho Federal de Educação - seleção de pareceres aprovados durante o semestre - Educação Moral e Cívica - Parecer no 136/64, C.E.P. e M., aprov. em 5-6-1964" RBEP, nº 95, jul./set. 1964, p. 116 - 139.

${ }^{287}$ Decreto $^{\circ} 68065$ - de 14 de janeiro de 1971. Regulamenta o Decreto-lei no 869 , de 12-9-1969, que dispõe sobre a inclusão da Educação Moral e Cívica, como disciplina obrigatória, nas escolas de todos os graus e modalidades dos sistemas de ensino no País, e dá outras providências. RBEP, nº 122, abr./jun. 1971, p. 365 375 .
} 
questões referentes à disciplina, havia uma Comissão Nacional de Moral e Civismo, composta por nove membros nomeados pelo presidente da república, que trabalhava articulada aos órgãos da censura. A formação de Centros Cívicos nas escolas era incentivada como uma forma de estimular a organização de atividades colaborativas entre os alunos. Tais associações deveriam "considerar o civismo em três aspectos fundamentais: caráter, com base na moral, tendo fonte em Deus, nos termos do Preâmbulo da Constituição do Brasil; amor à Pátria e às suas tradições, com capacidade de renúncia; ação intensa e permanente em benefício do Brasil" (p. 373). Assim que o decreto foi regulamentado, a orientação dada acerca daqueles que deveriam ministrar a disciplina era a seguinte: "enquanto não houver professores e orientadores de Educação Moral e Cívica, a habilitação será feita por meio de exames e suficiência" (p. 374). O decreto ainda tratava da "Cruz do Mérito da Educação Moral e Cívica", prêmio que havia sido criado em 1969, seria conferido pelo ministro da educação e da cultura, mediante proposta da comissão referida anteriormente, a personalidades que se destacassem em esforço e em dedicação à “causa da Educação Moral e Cívica”.

Em artigo publicado na RBEP no ano seguinte, após a promulgação da LDB $\mathbf{n}^{\mathbf{0}}$ 5.692, de 1971, que, dentre outros elementos, unifica o antigo ensino primário ao ginásio e instaura o ensino de $1^{\circ}$ grau, Valnir Chagas ${ }^{288}$, membro do Conselho Federal de Educação, apresenta considerações acerca dos currículos do ensino de $1^{\circ}$ e $2^{\circ}$ graus. Em seu texto, a Educação Moral e Cívica e a OSPB são consideradas como disciplinas que promoveriam a integração dos alunos ao meio. Elas visariam ao preparo para o exercício consciente da cidadania, ao civismo, à "tomada de consciência da cultura brasileira e do processo em marcha do desenvolvimento nacional" (p. 40). A matéria também deveria promover o fortalecimento da unidade nacional e a condenação ao tratamento desigual por motivo de convicção filosófica ou religiosa, e também poderia integrar-se aos Estudos Sociais e aos Programas de Saúde em Ciências. Aldo Perracini, no livro A escola renovada, publicado em 1972, apresentou o planejamento que deveria ser seguido pelos professores ao ministrar aulas de Educação Moral e Cívica. A disciplina deveria abordar o desenvolvimento do Brasil, o trabalho, a pátria e as comemorações cívicas. Fábulas, como "A cigarra e a formiga", poderiam ser utilizadas para apresentar valores morais, como a importância do

${ }^{288}$ CHAGAS, Valnir.(do Conselho Federal de Educação) "Núcleo comum para os currículos do ensino de $1^{\circ}$ e $2^{\circ}$ graus" (p. 32 - 58) RBEP, n 125, jan./mar. 1972, p. 32 - 58. 
trabalho para o desenvolvimento da sociedade (p. 84). As excursões também consistiam em práticas recomendadas para o ensino desta matéria, que poderiam ter como temas de estudo do meio "a administração da cidade" (p. 130). O planejamento para o $1^{\circ}$ semestre, na $4^{\text {a }}$ série, por exemplo, seria o seguinte: “Tema: 'Ninguém mais segura este país'. Educação moral e cívica. Trabalho como fonte de desenvolvimento. Pátria - símbolos nacionais. Os poderes/grandes vultos da História Brasileira" (p. 82).

De acordo com parecer ${ }^{289}$ do Conselho Federal de Educação acerca do ensino dos Estudos Sociais no âmbito do $1^{\circ}$ Grau, publicado na RBEP em 1973, os livros didáticos deveriam manter-se "distintamente" voltados para a Educação Moral e Cívica. O texto também defendia a aprendizagem não compartimentada e a integração das disciplinas (História, Geografia, OSPB e Educação Moral e Cívica) mediante a coordenação de um professor, dentro da programação integrada da área de estudos, que desenvolveria aspectos geográficos, históricos, organizacionais e cívicos dos Estudos Sociais. Entre as diversas maneiras de divulgar os padrões de conduta pretendidos pelo governo militar, os livros didáticos também tiveram um papel importante. No período, os antigos livros didáticos foram reestruturados e novos livros foram publicados, com o objetivo de atender às prescrições legais. Para o professor Imideo Giuseppe Nérici, autor do manual pedagógico intitulado Ensino renovado e fundamental, reeditado em 1975, através do ensino da Educação Moral e Cívica as escolas deveriam formar uma escala de "valores sóciomorais", como "a justiça, o dever, a dedicação à Pátria e o amor a Deus" (p. 84). A disciplina História deveria auxiliar a Educação Moral e Cívica que, por sua vez, deveria conscientizar os alunos "sobre os deveres de cada um com a família, sociedade, pátria, religião" (p. 103). O ensino deveria ser o mais voltado para a prática quanto fosse possível, através da admiração pelos bons exemplos e fazendo uso de visitas, excursões e a atividades extra-classe que favoreceriam a formação moral e social. $\mathrm{O}$ autor também propunha que fossem realizados estudos sobre valores como o sacrifício, o esforço e deveres para com a Pátria. Os centros cívicos deveriam auxiliar os professores e demais funcionários da escola nas preparações para as comemorações das datas pátrias.

O ensino da moral e do civismo esteve presente no currículo das escolas brasileiras em outros momentos, não como uma disciplina específica, mas como saberes que

289 “Conselho Federal de Educação: Estudos Sociais no Ensino de $1^{\circ}$ Grau" RBEP, n 129, jan./mar. 1973, p. $148-152$. 
pertenciam a diversas disciplinas. No entanto, durante o período da ditadura militar esses saberes foram deslocados dessas disciplinas para tornarem-se uma disciplina específica, a Educação Moral e Cívica, que pretendia conduzir a formação escolar segundo padrões de conduta pretendidos pelo regime militar. A matéria permaneceu no currículo oficial como disciplina escolar e prática educativa em todos os níveis de ensino de 1969 até 1993, quando foi revogada pela Lei $\mathbf{n}^{\circ} \mathbf{8 . 6 6 3}^{290}$. No governo militar, a educação foi controlada política e ideologicamente, sendo utilizada de maneira estratégica: ela deveria promover a formação de capital humano, atendendo as necessidades da produção e do mercado (SKIDMORE, 1982; SODRÉ, 1988). Às escolas caberia difundir uma nova mentalidade e desenvolver nos indivíduos o patriotismo e o espírito nacional. O modelo de socialização pretendido pelos militares tinha como estratégia fazer uso da educação escolar para incutir nos alunos valores morais que os conformassem e os preparassem para aderir à representação da família tradicional, cumprindo bem o papel que cabia desempenhar ao homem e à mulher na manutenção dos vínculos familiares. Dada a força ideológica que a Igreja católica tem no Brasil, o discurso e os valores religiosos também foram incorporados ao discurso militar, estando presente na própria legislação federal. Tal proposição fica explícita no próprio decreto-lei $\mathbf{n}^{\mathbf{0}} \mathbf{8 6 9}^{291}$ de 1969, que institui a disciplina educação moral e cívica como disciplina obrigatória em todo o sistema de ensino do país: "art. $2^{\text {o. }}$ preservar o espírito religioso, sob a inspiração de Deus. Desenvolvimento da vontade, fazendo-o feliz e útil à comunidade (...) Nacionalidade, fortalecimento da vontade, caráter. A constituição da família origina deveres para com Deus, para com a consciência individual e para com a sociedade. (...) Moral, originária da ética tendo por fonte Deus” (p. 157). Os militares mobilizavam o discurso religioso para reforçar a idéia de que era preciso valorizar a família enquanto instituição, considerada "sagrada" pelos católicos. Ao mesmo tempo, expressavam na legislação que defendiam a "democracia, espiritualista" em oposição ao "comunismo, ateu" (p. 163). O comunismo era temido por almejar a anarquia, pregar o amor livre e colocar em risco a estrutura familiar tradicional, tão cara e necessária

\footnotetext{
${ }^{290}$ Lei $\mathbf{n}^{\mathbf{0}}$ 8.663, de 14 de junho de 1993. Revoga o Decreto-Lei no 869, de 12 de dezembro de 1969, e dá outras providências. "Art. $1^{\circ}$ É revogado o Decreto-Lei no 869, de 12 de dezembro de 1969, que dispõe sobre a inclusão da Educação Moral e Cívica como disciplina obrigatória, nas escolas de todos os graus e modalidades, dos sistemas de ensino no País e dá outras providências".

291 "Educação moral e cívica no currículo escolar" Em decorrência do decreto-lei no 869, de 12/9/69, foi instituída uma Comissão Nacional de Moral e Civismo. Esse decreto institui a Educação Moral e Cívica como disciplina obrigatória. RBEP, n 117, jan./mar. 1970, p. 151 - 176.
} 
aos objetivos militares. Ou seja, quem valorizava a família e a "democracia" acreditava em Deus, quem não valorizava, era comunista, ateu e carecia de conformação moral.

Incutir o civismo na formação escolar consistia numa grande preocupação para os militares, à medida que era necessário fazer o indivíduo crer que ele pertencia a algo muito maior do que ele próprio, a pátria, e que por ela ele precisava trabalhar. Para que a pátria progredisse e amparasse a todos, cada um deveria cumprir o seu papel (OLIVEIRA, 1982). A moralização dos alunos nessas condições históricas e sociais pertencia também a um projeto de mobilização nacional que visava à construção e à manutenção de um Estado forte. Segundo Jaime Abreu ${ }^{292}$, em artigo publicado na RBEP em 1961, no período da ditadura do Estado Novo (1937-1945), já havia a intenção de doutrinar os docentes e os discentes na concepção do "Estado forte". Para tanto, desenvolver e cultivar nos alunos os sentimentos de civismo e de patriotismo era fundamental. Assim, a obrigatoriedade da disciplina de educação moral e cívica foi uma maneira de institucionalizar um ideário nacionalista, visando à construção de uma nação cuja força seria baseada na inculcação de valores morais que ressaltavam a importância da família, do patriotismo e da religião. $\mathrm{O}$ cidadão que o governo militar pretendia formar deveria valorizar a família, a pátria e os princípios cristãos.

Desde o governo de Vargas, no começo dos anos de 1950, a proposta de disseminar pelo país a idéia de nação enquanto espaço coletivo teria o objetivo de integrar o país e eliminar as tensões sociais acarretadas pela desigualdade social e pela situação econômica. O impulso da industrialização abalava a estrutura social à medida que trazia insegurança às classes tradicionais ligadas ao comércio de importação e exportação agrícola. Contudo, a classe média apoiava a industrialização e a modernização por defender que o Brasil precisava ter controle sobre a sua própria economia. A classe operária urbana também apoiava o nacionalismo econômico de Vargas. Nas palavras de Thomas Skidmore (1982), "o nacionalismo econômico, portanto, poderia ser muito útil como meio de edificar um consenso popular. O nacionalismo era um sentimento que podia unir brasileiros de diversas classes e setores, dar-lhes um senso de comunidade. Como argumentavam os apologistas intelectuais do nacionalismo desenvolvimentista, a identificação com a nação em um esforço comum poderia ajudar a superar as tensões de classe produzidas por uma sociedade

\footnotetext{
${ }^{292}$ ABREU, Jaime. “Os estudos sociais na escola média” RBEP, nº 82, abr./jun. 1961, p. 151 - 154.
} 
em desenvolvimento" (op. cit., p. 143). O nacionalismo que trazia a imagem de um Estado forte e que pretendia deter o controle de sua própria economia teve como marca a criação de empresas estatais como a Eletrobrás e a Petrobrás. Esse sentimento que podia unir os brasileiros e dar-lhes um senso de comunidade continuou a ser muito útil ao governo anos mais tarde, no período da ditadura militar. A obrigatoriedade da inclusão da disciplina educação moral e cívica parece fazer parte desse movimento de reestruturação nacional, iniciado na década anterior, e ultrapassava o âmbito escolar. Assim, o civismo, enquanto um padrão de conduta desejável a todos os membros da nação, marcado pela passividade, deveria incutir em cada cidadão o sentimento de obrigação para com o país e para com a sociedade, engendrando em cada um a necessidade de cumprimento das suas funções sociais e profissionais.

\subsection{A EDUCAÇÃO E A SEGURANÇA NACIONAL}

Se, nos anos de 1960, a censura empreendida pelo governo militar era justificada por proteger a instituição da família, preservando-lhe os valores éticos e assegurando a "formação sadia e digna da mocidade", os valores pregados pelo cristianismo eram então evocados na lei por proteger a moral e auxiliar o governo na defesa da instituição familiar. Designar aqueles que praticassem os "bons costumes" como "pessoas honestas, corretas, de boa-fé" mediante todo o processo de moralização levado a cabo pela escolarização dos indivíduos, também seria uma maneira de tentar evitar conflitos e violência. Conter as idéias revolucionárias trazidas pelo comunismo e a mudança no comportamento dos jovens promovida pelo desenvolvimento dos meios de comunicação, por exemplo, metamorfoseando os valores cristãos através do discurso militar e valorizando a integridade da família brasileira, também eram formas de garantir a segurança nacional. Quando a moral da sociedade se via ameaçada, assim estava ao mesmo tempo a segurança dos indivíduos que viviam nela. Tal caráter preventivo exercido pela educação moral e gerador da integração vida em sociedade também esteve presente nas fontes consultadas. Mediante o desenvolvimento de atitudes morais e do compromisso com os deveres cívicos e profissionais, habilitando o indivíduo para o convívio no ambiente familiar, a vida social seria garantida. A propósito disso, John Dewey foi citado com freqüência, defendendo, entre outras questões, a idéia de que a educação teria o poder de eliminar os males sociais. 
Tão importante quanto os hábitos sociais e morais que deveriam ser adquiridos na escola visando ao convívio coletivo, era a formação do desejo: porque os elementos emotivos de caráter moral seriam conquistados mediante o "desejo" de se ter uma vida sadia e feliz para si e para os seus semelhantes (MATTOS, 1967). As práticas desligadas do desejo e da vontade não seriam capazes de acompanhar o desenvolvimento das crianças até a fase adulta, para que elas permanecessem e fossem aperfeiçoadas com o passar do tempo: era necessário que estivessem como que incrustadas na alma dos indivíduos. Para que os hábitos fossem formados e as atitudes exercitadas, era essencialmente à alma e não ao corpo que a moralização deveria voltar-se. Em oposição à teoria behaviorista e à educação voltada para os automatismos, parecia estar situada a moralização no processo de escolarização das pessoas. Gustavo Lessa ${ }^{293}$, médico e sanitarista, em artigo publicado na RBEP em 1953, no qual tratava sobre a formação de hábitos na idade pré-escolar dizia que o importante para a educação é a "fase preventiva", na qual é possível impedir a formação dos maus hábitos. Defendendo a educação infantil, criticava "o individualismo brasileiro. A falta de espírito de cooperação provém do medo que eles têm de que o filho brinque livremente. Além disso, o número de jardins de infância é ainda muito pequeno”. (p. 163) Enquanto Lessa tratava do caráter preventivo que poderia ser alcançado por meio da escolarização, mediante a formação de hábitos na pré-escola, graças à plasticidade da infância, Anísio Teixeira ${ }^{294}$, no ano seguinte, em artigo publicado na mesma revista, expressava sua preocupação quanto à organização do sistema de ensino brasileiro e a sua ineficiência no tocante à promoção da segurança nacional. Acerca da influência que os jesuítas trouxeram para a formação do país, o autor dizia: "O Brasil amanheceu para a história sob a influência espiritual e intelectual da Companhia de Jesus, organizada como força de vanguarda da contra-reforma religiosa. Buscavam no novo mundo o que se perdera no velho, reafirmando a doutrina da autoridade externa ao indivíduo e o conceito de disciplina social pela obediência à autoridade espiritual e temporal, ambas de origem divina" (p. 7). Teixeira criticava o governo brasileiro e a sua legislação por manterem "padrões" pré-concebidos, uniformes e artificiais, inspirados e fundados nas escolas européias, para uma nação nas “condições mais desencontradas possíveis”. Acerca da

\footnotetext{
${ }^{293}$ LESSA, Gustavo. (Educação, Rio) “A formação de hábitos na idade pré-escolar” RBEP, n 50, abr./jun. 1953, p. $159-164$.

${ }^{294}$ TEIXEIRA, Anísio. “Padrões...” RBEP, nº 55, jul./set. 1954, p. 3 - 22.
} 
degradação das condições escolares, o autor afirmava que o "esforço disciplinador" só poderia ser conseguido se o governo harmonizasse os seus poderes e os recursos para o desenvolvimento de suas instituições de ensino, que estariam desligadas da realidade e da cultura, com currículo e programas uniformes. Este sistema, segundo ele, estaria "sendo liquidado pela própria expansão escolar desabrida. As leis de ensino estão em avançado processo de desmoralização. Só quando for superada a fantasia dos sistemas uniformes e forem dados recursos para que a escola se crie é que poderemos falar do meio social purificador e renovador, do qual fala Dewey, refletindo como um espelho a sociedade que a serve. Só assim a escola contribuirá para a solidariedade e a segurança nacionais” (p. 15).

A influência norte-americana, da filosofia da "social efficiency" evocada por Dewey esteve presente nos discursos dos autores que associavam educação, civismo e democracia, como Anísio Teixeira e Luiz Alves de Mattos, por exemplo. Teixeira teve contato com Dewey no final dos anos de 1920, nos Estados Unidos, país no qual realizou os seus estudos de pós-graduação, quando teve contato com as idéias do autor americano, que muito influenciaram o pensamento e a obra do educador brasileiro ${ }^{295}$. Defendidas pelo autor americano, a eficiência cívica, garantida pela inserção dos indivíduos na comunidade, e a eficiência ética e moral, garantidas pelo desenvolvimento de virtudes morais e sociais, que seriam valiosas para a manutenção e para a segurança da vida em sociedade, também eram enunciadas por Mattos em seu livro, Sumário de didática geral, reeditado em 1967. A aquisição de virtudes morais e sociais promoveria a segurança, o bem estar e o progresso do grupo social ao qual os alunos pertencessem. Nise Pires ${ }^{296}$, pesquisadora no INEP, em artigo publicado na RBEP em 1970, dizia que a educação escolar deveria proporcionar ao educando uma formação básica que o capacitasse para integrar-se ao meio no qual vivia, para que ele agisse em decorrência de uma adequada formação moral e cívica: "a educação fundamental justifica-se amplamente também sob o ângulo político. Em face da Constituição, 'toda pessoa, natural ou jurídica, é responsável pela segurança nacional, nos limites definidos em lei' (art. 86). Tal responsabilidade pressupõe uma base de formação moral e de educação para a cidadania, condições vivificantes da democracia." (p. 65 grifos meus) Evocando a Constituição, a autora deixava claro uma das faces da educação

\footnotetext{
${ }^{295}$ Foi Anísio Teixeira quem traduziu, pela primeira vez em português, dois livros de Dewey: A Criança e o Programa Escolar São Paulo: Abril Cultural, 1980 e Interesse e Esforço São Paulo: Abril Cultural, 1980.

${ }^{296}$ PIRES, Nise. "Educação Fundamental" RBEP, nº 117, jan./mar. 1970, p. 63 - 73.
} 
moral praticada na escola. Através de autores brasileiros, pensamentos como os de Dewey, por exemplo, transitavam por livros e artigos e fundamentavam e ajudavam a pensar em questões particulares a essa sociedade com teorias que foram elaboradas inicialmente longe daqui.

\subsection{A PÁTRIA E O NACIONALISMO}

O professor João José da Silveira Campos ${ }^{297}$, em artigo publicado na RP em 1960, ao escrever sobre a formação da consciência econômica e profissional, iniciava o texto evocando uma parábola de Jesus Cristo ao dizer que quem "empresta aos pobres dá a Deus" (p. 6). Para o autor, o magistério deveria atuar na formação da consciência econômica e profissional, confrontando o "nacionalismo xenófobo e o patriotismo universal" visando à "proteção da civilização e de estabilidade social" (p. 6). A exemplo deste artigo, ao longo da pesquisa muitas vezes foi possível perceber que os valores cristãos foram apropriados pelos autores, seja dos manuais pedagógicos, seja dos periódicos educacionais, e até mesmo nos textos legais, ao visarem à promoção do civismo, da cidadania e do patriotismo. A estrutura do pensamento religioso, das práticas religiosas, é transposta para a escola e utilizada para alcançar os objetivos do ensino liberal, para formar e sustentar uma sociedade liberal. Jaime Abreu ${ }^{298}$, então diretor da Divisão de Estudos e Pesquisas Educacionais do CBPE, em artigo publicado na RBEP em 1961, a propósito do ensino de estudos sociais, dizia, acerca do nacionalismo, que era muito difícil questionar as "crenças nacionais". Do ponto de vista de uma sociedade democrática, seria preciso "abrir essas áreas para um livre exame". Acerca da expansão do ensino, Abreu dizia o seguinte: "com a clientela escolar heterogênea e com interesses conflitantes, é preciso lidar com esses problemas" (p. 152). Os problemas a que o autor se referia, relacionados principalmente à ausência de hábitos morais nas crianças de origem social mais pobre que então ingressavam nas escolas, poderiam ser solucionados mediante a "preparação para um lúcido exercício de cidadania. Antigamente havia a disciplina

\footnotetext{
${ }^{297}$ CAMPOS, João José da Silveira. "Formação da consciência econômica e profissional" RP, abr./1960, p. 6.

${ }^{298}$ ABREU, Jaime. “Os estudos sociais na escola média” RBEP, nº 82, abr./jun. 1961, p. 151 - 154.
} 
'Instrução Moral e Cívica', e alcançar objetivos morais e cívicos cabia exclusivamente a ela e não era considerado uma tarefa global da escola. Ela era inadequada e retórica" (p. 163). O autor criticava a maneira como os estudos sociais vinham sendo ministrados nas escolas, que desconsiderava diversidade entre as pessoas originárias de diversas classes, o que causava "confusões e equívocos". O professor Wilson Martins ${ }^{299}$, em artigo publicado na RBEP em 1957, afirmava que educar é substituir o homem natural pelo homem social. As crianças deveriam ser formadas "pela nação e para a nação". Segundo o autor, a educação delas seria, para o legislador, "um meio de uni-las à Pátria, para lhes inspirar o espírito da comunidade, as virtudes públicas e privadas, o amor honesto, as paixões úteis ao Estado, para lhes dar e conservar a espécie de caráter, de gênio que convém à Nação" (p. 128). No livro Introdução ao Estudo da Escola Nova, na reedição de 1965, Lourenço Filho dizia que "a Escola Nova deve preparar o futuro cidadão a preencher seus deveres com a pátria e com a humanidade" (p. 165). No livro Didática Geral, em reedição também de 1965, Afro do Amaral Fontoura sugeria aos professores que cuidassem da personalidade dos educandos e trabalhassem pelo engrandecimento da pátria brasileira.

O professor Imideo Giuseppe Nérici, no livro Ensino renovado e fundamental, reeditado em 1975, ressaltava a importância de que a educação escolar realizasse "um trabalho sócio-moral no educando, freando o egoísmo" (p. 21), ensinando direitos e deveres necessários ao exercício da cidadania. Ao citar o pedagogo Álvaro $\mathrm{Neiva}^{300}$, dizia que a educação deveria formar o cidadão participante, que valorizasse "o Amor à Pátria, a Fidelidade à Família, a Reverência a Deus” (p. 28). Esses três princípios poderiam ser efetivados em atividades extra-classe e complementariam a formação moral. Mediante o ensino da Educação Moral e Cívica, deveria ser transmitida aos alunos uma escala de valores sócio-morais, como "a justiça, o dever, a dedicação à Pátria e o amor a Deus” (p. 84). Teobaldo Miranda Santos, no livro Metodologia do ensino primário, da reedição de 1955, defendia que o "amor à pátria" e o "espírito cívico" poderia ser incutido nos alunos também através das disciplinas história e geografia. Quanto à metodologia de geografia,

\footnotetext{
${ }^{299}$ MARTINS, Wilson. "O novo Emilio (O que a educação pode esperar das ciências sociais)" RBEP, nº 66, abr./jun. 1957, p. $125-142$.

${ }^{300}$ Designado por Lourenço Filho, então diretor do INEP, o pedagogo Álvaro Neiva foi um dos integrantes de uma comissão encarregada de organizar do Colégio Pedro II, além de introduzir os princípios escolanovistas em uma escola em Cruzeiro (SP).
} 
Santos dizia que fossem trabalhados em aula: "amor à Pátria, valores espirituais, integrar a criança ao meio social” (p. 211). Em relação à metodologia de história, o autor sugeria que esta disciplina fosse ministrada como "instrumento de educação cívica, amor à nação e à Pátria" (p. 225). Desenvolvendo o "sentimento de brasilidade", o "amor às tradições nacionais" e os ideais de civismo, o ensino primário deveria fazer com que as crianças compreendessem dos valores de seu país, o caráter dos homens e dos cidadãos: "a escola deve despertar a consciência de sua co-responsabilidade na vida do povo e do Estado, bem como o amor à nação e à pátria" (p. 223). Assim como Santos, a professora Brisolva de Brito Queirós, no manual pedagógico intitulado Didática do ensino primário - prática de ensino, reeditado em 1960, também defendia que o "amor à pátria" poderia ser incutido nos alunos mediante o ensino de história e de geografia. O ensino de História do Brasil traria, em seu programa, "comemoração de datas cívicas, feriados nacionais, vultos notáveis da História da Pátria” (p. 79). A disciplina deveria favorecer a formação moral, os sentimentos de civismo e uma "melhor compreensão de normas de conduta" e um "maior sentimento de amor ao Brasil” (p. 82). O ensino de História favoreceria a formação moral e desenvolveria sentimentos cívicos, mediante o conhecimento da personalidade dos vultos históricos e dos símbolos da Pátria. De acordo com a autora, a matéria precisaria "focalizar a força viva do exemplo através das personalidades estudadas, em todos os setores da história" procurando "colaborar na obra de engrandecimento nacional; canto de hinos música e letra" (p. 174-175) Enquanto prática caberia à disciplina promover as comemorações cívicas, culturais e religiosas, assim como as festas das grandes datas nacionais. Geografia deveria "despertar e desenvolver interesse pelos problemas nacionais" (p. 172). Entres as práticas realizadas nas escolas para integrar as crianças à sociedade $\mathrm{e}$ levar as mesmas a aderir à idéia de nação estão as comemorações cívicas, com as suas festas e os seus desfiles.

Mediante os estudos das práticas e das representações que estiveram presentes na escola pública paulista durante o seu período de expansão, é possível afirmar que o discurso cívico, evocado em nome da nação, contribuía para a configuração do sentimento de patriotismo nos indivíduos como o esquecimento deles próprios. Seja fazendo-se esquecer para os outros, anulando os seus desejos e as suas paixões, seja formando a sua vontade em função dos seus dirigentes, é possível afirmar, assim como fez Rui Barbosa, que a "maior das verdades táticas é que os povos se defendem principalmente com o 
coração de seus soldados", ou com a subjetividade dos seus cidadãos. Sob a égide dos militares, a educação moral desenvolvida nas escolas visava à formação de posturas desejáveis a todos os cidadãos, que deveriam servir à pátria mesmo não sendo soldados. Através das representações veiculadas nas fontes consultadas, o indivíduo moralizado, sob esse espectro, deveria ser obediente, formar uma família e valorizá-la, cumprir com as suas funções sociais e profissionais, acreditar que estava protegido pelo Estado-nação e para ele dedicar todo o seu esforço e o seu sacrifício. O próprio conhecimento mobilizado para a formação dos cidadãos atendia a essa lógica, forjando uma compreensão do sentimento de "brasilidade" associado à necessidade de cultivar um "amor" ao Brasil, mediante, por exemplo, o canto dos hinos nacionais, que deveriam desenvolver os "sentimentos cívicos", o ensino da história nacional que mostrava que o país estava em pleno progresso e caminhava para o futuro - associado à admiração dos "vultos" históricos e das "figuras ilustres", e da geografia que ensinava o quanto o país era rico em seus recursos naturais e que estes deveriam ser explorados em prol de seu desenvolvimento. As disciplinas ajudavam o Estado a divulgar uma imagem que havia forjado de si próprio e, nas palavras de Bourdieu (1996), "através do enquadramento que impõe às práticas, o Estado instaura e inculca formas e categorias de percepção e de pensamento comuns, quadros sociais da percepção, da compreensão ou da memória, estruturas mentais, formas estatais de classificação. E cria, assim, as condições de uma espécie de orquestração imediata do habitus que é, ela própria, o fundamento de uma espécie de consenso sobre esse conjunto de evidências compartilhadas, constitutivas do senso comum" (op. cit., 116-117). Assim, as práticas realizadas a partir das representações que o Estado divulgava através da educação escolar contribuíam para a moralização dos agentes que seriam úteis à pátria e favoreciam a segurança nacional na medida em que os fazia engendrar deveres para com os seus compatriotas e com a nação e crer na proteção que esta lhes daria. Esses mesmos deveres, no âmbito escolar, favoreciam a constituição do autogoverno entre os alunos, que era útil para que o sistema escolar administrasse o ingresso de uma clientela escolar tão grande quanto variada em sua origem: se cada um governasse a si próprio, todos estariam governados sem que fosse necessário o uso de instrumentos de coerção física, que não era desejável nem às escolas, por conta da influência da psicologia e dos ideais da Escola Nova que ainda ressoavam, nem ao Estado que, ao fazer uso do poder simbólico, produzia nos agentes estruturas cognitivas incorporadas, de acordo com as estruturas objetivas, que asseguravam a crença e a submissão à ordem estabelecida. 


\section{CONSIDERAÇõES FINAIS}

"Você já sabe onde se oculta esse outro mundo, já sabe que esse outro mundo que busca é a sua própria alma. Só em seu próprio interior vive aquela outra realidade por que anseia. Nada lhe posso dar, que já não exista em você mesmo, não posso abrir-lhe outro mundo de imagens além daquele que há em sua própria alma. Nada lhe posso dar, a não ser a oportunidade, o impulso, a chave. Eu o ajudarei a tornar visível o seu próprio mundo, e isso é tudo."

(Hermann Hesse, O lobo da estepe, 2010, p. 189)

No romance O lobo da estepe, o escritor alemão Hermann Hesse conta as aventuras de um intelectual de 50 anos, o lobo, que passa por uma crise existencial. Ao ver-se no limite de suas forças morais - daquilo que o mantinha vivo e o ligava ao meio social no qual vivia - ele vê sua vida desmantelar-se. Passando por uma espécie de reeducação moral ao contrário, ele começa a dar vazão aos seus impulsos que haviam sido sufocados, mas que permaneciam nele. Não por acaso, a possibilidade de revisão da sua história e de seu passado ocorre em um lugar chamado Teatro Mágico, cujo cartaz anuncia que se trata de um espetáculo "só para loucos". Perdidos no labirinto dos próprios desejos, os indivíduos carecem de conformação moral para que aprendam a querer, a controlar as suas paixões, a agir de acordo com os princípios esperados por aqueles que habitam a sociedade junto com eles e a alcançar a maestria de si, dispensando então o uso de qualquer instrumento de coerção porque, nesse caso, já seriam eles próprios os seus condutores e os seus censores. Caso contrário, se hipoteticamente eles fossem entregues à própria sorte, até poderiam dar vazão aos seus instintos e levariam uma vida mais livre, mas também selvagem. Não é por acaso que são chamados de "loucos" aqueles que, de modo inesperado, modificam o rumo de sua vida. A loucura, para além de designar uma doença psíquica, representa a liberdade, uma fuga da realidade tal como ela está construída, ou forjada.

No esforço de tentar escrever uma história das práticas e das representações de moralização nas escolas primárias, foi feito o exercício de olhar para o passado através dos 
registros escritos e de interpretá-los de acordo com as condições históricas e sociais nas quais se produziram. A fotografia escolhida para a capa desta tese representa esta operação. Na imagem, as crianças, do lado de fora da escola, tentam olhar para dentro dela através dos vidros da janela e imaginam, a partir daquilo que conseguem observar, o que se passa dentro daquele espaço. As fontes examinadas aqui representam a janela escolhida para que se olhasse para o passado. No cenário apresentado foi visto que, para que a educação moral estivesse inculcada nos indivíduos e fosse transformada em prática, era àquilo que era chamado de alma que ela deveria ser dirigida. Para controlar a alma das pessoas, no dizer dos homens do período, as representações da conformação moral eficiente mesclavam referências psicológicas, religiosas e cívicas, que formavam uma espécie de ciranda da qual o indivíduo - que talvez não pudesse ser chamado de sujeito porque não havia sido abandonado a si próprio e, portanto, não era "livre" - precisava fazer parte, unindo-se a uma daquelas referências ou, na maior parte das vezes, unindo-se às três. Se nos primeiros anos de vida as crianças estariam presas às suas próprias vontades e poderiam ser consideradas escravas dos próprios desejos - o que seria compreensível pelos adultos, já que elas ainda não haviam sido suficientemente moralizadas, sendo, portanto, inocentes quanto às regras do jogo - mediante o processo de conformação moral elas teriam a sua subjetividade voltada para algo maior que si próprias: Deus, a pátria e a coletividade. No período investigado, foi possível perceber que a subjetividade dos alunos e dos professores primários das escolas públicas paulistas, era mobilizada de modo a atender a questões que estavam muito além das necessidades individuais, mas atendiam a motivações de ordem governamental, social e econômica. Os atos motivados pela educação moral constituem-se em meios de impor ordem e organização às nações. Ao empreender a educação moral, a escolarização dirige o comportamento coletivo, seja no sentido da preservação, seja no sentido da mudança, consistindo num importante dispositivo político. No período histórico estudado, a moralização dos agentes da escola foi importante para contribuir com a configuração da forma escolar que se delineava durante a expansão do ensino.

Neste trabalho, buscou-se considerar as fontes de acordo com as condições de sua produção. Elas evidenciaram que os professores, especialmente as professoras primárias, ao longo da sua formação, passavam por um processo que pretendia transformá-las em um tipo de pessoa, que serviria de exemplo aos alunos. Fazendo-as esquecer de si próprias, 
elas precisariam ser a encarnação da moral aos olhos das crianças e deveriam incorporar a "maternidade escolar", dirigindo a elas um "amor incondicional". Quanto à clientela escolar mais pobre que chegava à escola por conta da expansão do ensino, a moralização poderia, de acordo com a literatura pedagógica examinada, realizar uma espécie de "profilaxia", promovendo a integração social das pessoas oriundas de lares desorganizados, se não eliminando, ao menos atenuando as marcas de sua origem evidenciadas através de seu comportamento. A escola primária foi representada, em muitos momentos, como a instituição que poderia "corrigir" os alunos originários de famílias mais pobres. Ao recebêlos, seria como se ela pudesse também "corrigir" o destino dessas crianças. Ainda com relação à origem sócio-econômica da clientela escolar, a professoras eram vistas como mães que deveriam cuidar e suprir as carências que não haviam sido supridas em casa. A integração social inicialmente caberia à família, mas por conta da pobreza, do divórcio e de doenças como a sífilis e o alcoolismo, que implicavam na conduta moral das pessoas, a tarefa ficou exclusivamente a cargo da escola que, além de ensinar a escrever, a ler e a contar, haveria de ensinar uma conduta considerada adequada e que permitiria aos indivíduos a sua plena integração social, apesar de sua origem familiar.

Associada à promiscuidade, para além das questões econômicas, a pobreza também seria um mal e desta forma deveria ser combatida porque ela era considerada "amoral". É possível perceber, através das representações veiculadas nas fontes consultadas, que a abertura das escolas às massas promoveu um choque de capitais - social, econômico e cultural - entre os professores, os funcionários e entre a própria clientela escolar, que se tornou mais diversificada em sua origem, gerando um estranhamento que era visível mediante um discurso que atacava a moral, como é possível depreender através dos próprios termos utilizados para designar as crianças mais pobres e os seus pais: "vadios", "preguiçosos", "indolentes", etc. A associação entre a pobreza e a promiscuidade evidenciou um discurso determinista que fadaria o indivíduo ao fracasso devido à sua origem, caso ele não passasse pela escola, instituição responsável pela sua "salvação" e que tentaria eliminar as marcas de sua vida doméstica e familiar. A população mais pobre deveria redimir-se dos vícios e dos maus hábitos mediante a educação moral dos seus filhos.

As representações do indivíduo devidamente moralizado ou não, veiculadas tanto nos periódicos educacionais quanto nos manuais pedagógicos, associavam a pobreza aos 
vícios e a riqueza às virtudes. A escola era vista como a instituição que teria o poder de redimir as crianças pobres do mal advindo de sua origem e os professores, concebidos como os "salvadores", deveriam realizar o seu trabalho mediante quaisquer condições, não importa as dificuldades que tivessem. De acordo com os discursos veiculados nas fontes consultadas, ainda é possível depreender que a busca pela formação do caráter conduziria o indivíduo a moldar a sua personalidade, levando ao conhecimento, à conquista de si mesmo e à "verdadeira liberdade", de que tanto falaram os autores, especialmente quando movidos pelos ideais escolanovistas, o que pode ser entendido como a maestria de si, ou também como a autonomia moral. Influenciada pela Escola Nova e pelos métodos ativos, a educação moral seria aprendida através da prática, mas também mediante a observação e a convivência com exemplos que deveriam ser seguidos. Nas escolas primárias, caberia aos professores, e especialmente às professoras representar esse papel. É importante ressaltar mais uma vez que, mesmo consistindo em periódicos de natureza bastante distinta, tanto a Revista Brasileira de Estudos Pedagógicos (RBEP), que apresenta um caráter mais acadêmico e pretendia-se científica, quanto a Revista do Professor (RP), que foi produzida por uma associação docente, e trouxe textos escritos por pessoas que ocupavam diferentes posições no campo educacional - pesquisadores e professores universitários no caso da RBEP e professores primários, diretores de escola e inspetores escolares do caso da $\mathbf{R E}$ - são reiterados os valores originários da profissão docente. Ao longo de todo o período estudado, representações como, por exemplo, a do "professor sacerdote" e a da "professora mãe" foram mobilizadas constantemente pelos autores que escreveram nestas revistas. Assim, é possível afirmar mediante esse estudo que, de acordo com o material examinado, a representação do trabalho docente foi impregnada por um discurso ideológico que enxergava as professoras primárias como missionárias e que contribuiu também para a inércia de seu habitus.

Entre as práticas de moralização estudadas, destaca-se a substituição da palmatória e dos castigos físicos pelos castigos psicológicos que almejavam o controle da alma. Os instrumentos que traziam dor física deram lugar ao amor. Para tanto, a representação dos docentes recebeu novos contornos: da severidade que deveriam ter os professores dos primeiros grupos escolares, característica associada ao gênero masculino à amabilidade que precisariam demonstrar as professoras das escolas primárias, características associada ao gênero feminino, em seu período de democratização. A conformação moral deveria 
primar então por fazer com que as crianças se submetessem à disciplina pelo amor que deveriam ter pelas suas mestras, e não pelo medo. A disciplina deveria ser exercitada de dentro para fora. Essa substituição da coerção física pela coerção psicológica parece ter auxiliado no manejo empregado na educação das massas, que necessitava também que cada um educasse a si próprio. Ainda quanto às práticas com a finalidade de moralizar exercidas nas escolas primárias, as artes "escolarizadas", como a música e a literatura, por exemplo, poderiam ser mobilizadas para contar uma história, para rememorar um acontecimento importante, para despertar o sentimento religioso ou cívico. Contudo, em todas essas possibilidades, a moralização esteve presente. Ela seria como uma finalidade pedagógica da arte que só começou a ser contestada por alguns pesquisadores que escreveram na RBEP, por exemplo, no final dos anos de 1970.

Recorrendo a medidas de emergência como a multiplicação dos períodos de aula, o recrutamento de profissionais sem formação adequada e a adaptação de prédios para funcionarem como escolas, por exemplo, até o início dos anos de 1970, o sistema de ensino conseguiu atender à demanda de vagas no ensino primário, mas o processo de adaptação do sistema à nova e numerosa clientela escolar não ocorreu sem que houvesse conflito, seja com relação à adequação física e material dos espaços, seja com relação às diferenças de capital cultural que traziam essas crianças e também os professores primários que passaram a ingressar no magistério. Como foi visto ao longo deste trabalho, além da diversidade em relação à clientela que passou a ocupar o espaço escolar, a origem social dos professores primários foi modificada. Pensar a questão mediante a ótica do autogoverno permitiu compreender o quanto, na dificuldade de governar as massas e de gerir a diversidade no interior das instituições escolares durante a democratização, foi importante levar cada um a governar a si próprio: não apenas nas escolas primárias, mas também nos cursos de formação de professores. Tal como ocorreu em outros momentos da história da educação brasileira como, por exemplo, no período republicano.

Conformar moralmente as professoras primárias a tal ponto que elas fossem consideradas exemplos que deveriam ser seguidos pelos alunos e torná-las tão amáveis e ternas até que tivessem a sua identidade confundida com a da figura materna parecem ter consistido em estratégias que visavam não apenas à formação das crianças, mas que também tinham por objetivo controlar o trabalho docente. Assim, o autogoverno conquistado mediante o processo de conformação moral dos indivíduos, parece ter sido um 
elemento necessário à própria existência da democratização das oportunidades de educação pública. Submeter as crianças a atividades organizadas, de modo à regular o seu tempo, garantiria a sua ocupação incessante, mas também geraria disposições em relação à regularidade, promovendo o desenvolvimento de um tipo de comportamento propício a aquisição de uma forma de uma moralidade que é a do dever. As ações organizadas pela escola auxiliariam na promoção não apenas na ordenação dos trabalhos docente e discente, mas também levariam os alunos a adquirir hábitos de vida regular, de assiduidade, de pontualidade e a aprender condutas e disposição para o trabalho, necessários à configuração de uma sociedade marcada pela expansão demográfica, pela migração e pelo desenvolvimento industrial e urbano. Nas fontes consultadas e que foram publicadas entre o final dos anos de 1940 e durante a década de 1950, normalmente era sugerido que as escolas deveriam ensinar relações de mando e subordinação para formar a mão-de-obra necessária ao mercado de trabalho daquele momento, enquanto que, a partir dos anos de 1960 e durante a ditadura do governo militar, período no qual se vivia sob o estigma da ditadura e da repressão, é curioso observar como os ideais da Escola Nova eram evocados com frequiência para justificar a necessidade das escolas desenvolverem a cooperação entre as crianças, a autonomia e o uso da liberdade. Ao defender que os alunos trabalhassem não só para si, mas principalmente pelo grupo, se submetessem racionalmente às regras estabelecidas e administrassem a própria liberdade, o que as escolas criavam, mediante as suas práticas, era um dispositivo de ordenação política que tinha a necessidade do autogoverno em sua essência. Houve também uma mudança quanto à representação de liberdade enunciada pelas fontes examinadas: livre passa a ser aquele que sabe controlar o próprio comportamento e que tem o domínio de si próprio.

As professoras primárias eram formadas com a incumbência de moralizar e controlar os alunos através do próprio autocontrole. Como em uma correia de transmissão, esse modelo caminharia de uma geração à outra e a figura da professora primária, encarnação da regra, apareceria como uma imagem à qual as crianças deveriam aderir e inspirar a sua conduta. A instituição escolar moralizava o comportamento dos alunos através também do comportamento apresentado pelos professores. A representação do trabalho docente durante o processo de moralização dos alunos realizava-se na crença de que os educadores eram ativos, eficazes e de que a "natureza infantil" era moldável e educável. Contudo, ao receber uma clientela de origem social bastante distinta daquela que 
freqüentava os bancos escolares até os anos 1950, parece que um elo dessa correia foi rompido e o modelo deixou de ser tão bem reproduzido como no período anterior. A política de expansão de matrículas alterou profundamente a ocupação do espaço escolar. Nos anos de 1960, no caso dos alunos que concluíram o ensino primário e ingressaram no ginásio, por exemplo, o problema consistiu na resistência de grande parcela do magistério, que encontrou ressonância no pensamento pedagógico da época (AZANHA, 1987). Além da reprovação em massa, termos como "desajustados", "indisciplinados" e "vadios" aos poucos começaram a justificar as diferenças - devido às diversas origens sociais e econômicas - em relação ao comportamento dos então novos alunos que chegavam às escolas e alteravam a configuração do próprio modelo escolar. As escolas primárias passaram a representar não apenas um lugar para onde as crianças eram enviadas para aprender, a ler, a escrever e a contar, mas também configuraram uma espécie de rede de segurança que poderia detectar problemas médicos, psicológicos e sociais, mesmo que esses problemas fossem insolúveis do ponto de vista da ação da escola.

Se as pessoas são definidas por suas escolhas e delineadas pelos seus desejos, a educação moral orienta as escolhas, forma a vontade e inibe os desejos visando à formação de um "tipo" de pessoa, seja o bom cristão, seja o cidadão exemplar, seja o bom aluno ou a professora ideal adequados à realidade construída, ou forjada, socialmente. Como as trajetórias sociais e profissionais são fortemente tributárias das trajetórias escolares, a moralização realizada ao longo da educação escolar influencia diretamente na constituição do indivíduo que será, de acordo com o momento histórico, necessário à Igreja, à sociedade e à pátria. No caso paulista, no período investigado o desenvolvimento industrial aliado à migração, ao crescimento demográfico, às revoluções culturais e à expansão dos meios de comunicação demandava ao sistema de ensino que formasse mais do que trabalhadores, preparasse pessoas que estivessem dispostas ao trabalho, que valorizassem a família apesar das tentações que poderiam sofrer, e cidadãos que soubessem dos seus direitos civis, mas principalmente, que cumprissem com os seus deveres para com a pátria e para com os seus compatriotas e, também, que amassem e respeitassem a Deus. As forças exercidas pela família impulsionam os seus membros a aceitar um ponto de vista comum, inibindo a manifestação de opiniões mais egoístas e não por acaso ela está na gênese no discurso católico e foi apropriada por aquele enunciado pelos militares durante o seu governo no Brasil (1964-1985). Neste momento, também era preciso desenvolver nas crianças o 
patriotismo, principalmente durante o governo militar, mas as crenças não deveriam ser somente dirigidas à pátria, eram também voltadas a Deus. Esta ambigüidade marcou o caso brasileiro. Elemento principal da narrativa do sagrado, a fé esteve presente na educação brasileira desde as suas origens, tendo os padres como os seus primeiros professores. Se educação e doutrinação caminharam juntas desde os primórdios, não seria simples a sua separação. Assim como a moral laica, defendida por Durkheim, a moral religiosa também é formada por um conjunto de comportamentos cuja principal função é garantir a coesão social do grupo. Para o governo militar, contar também com a moral religiosa e instituí-la no âmbito de uma disciplina escolar obrigatória representou a união de dois discursos a favor de uma mesma causa. Os militares mobilizavam o discurso religioso para reforçar a idéia de que era preciso valorizar a família enquanto instituição, considerada "sagrada" pelos católicos. Ao mesmo tempo, expressavam na legislação que defendiam a "democracia, espiritualista" em oposição ao "comunismo, ateu". O comunismo era temido por almejar a anarquia, pregar o amor livre e colocar em risco a estrutura familiar tradicional, tão cara e necessária aos objetivos militares. Ou seja, quem valorizava a família e a "democracia" acreditava em Deus, quem não valorizava, era comunista, ateu e carecia de conformação moral. Como foi visto, a partir do final do século XIX, foi sobretudo por meio da educação primária que o Estado exerceu uma ação unificadora ao impor uma cultura nacional considerada legítima, atuando na construção da representação do Estadonação. No âmbito da moralização no período investigado, foi possível notar que o Estado, ao tentar anular as resistências dos indivíduos durante o período da ditadura militar, mediante o seu poder simbólico, atuava na construção das práticas e das representações dos seus agentes e na orquestração dos habitus, mas o fazia utilizando também o discurso religioso, revestindo os valores cristãos de uma aparente laicidade, mas mantendo as suas propriedades iniciais, e inserindo-os nas normas de conduta dos indivíduos. Como é o caso da caridade, por exemplo. A prática da caridade presente no discurso religioso, por exemplo, enquanto elemento fundamental para a configuração de dispositivos políticos, poderia ser transformada em solidariedade no discurso cívico e em altruísmo no discurso psicológico, no entanto, o seu sentido era mantido.

Aliada à censura, a disciplina Educação Moral e Cívica contribuiu com a propagação de idéias de "ordem e progresso" e com a perpetuação de práticas necessárias à manutenção do governo militar. O problema apresentado pelos meios de comunicação à 
moralização dos indivíduos estava na livre circulação das idéias, porque pelas idéias as pessoas poderiam ser induzidas a aderir a algo, daí o perigo representado pela mídia e pelo comunismo. Além disso, as famílias consideradas "desestruturadas" e os pobres, tido como pouco dotados de pudores e de autocontrole, poderiam ceder mais facilmente aos desejos e aos vícios, colocando em risco a segurança alcançada pelo estabelecimento das normas de convivência e ameaçando um retorno à barbárie. Os valores sociais e morais, para que prevalecessem e fossem colocados em prática, sendo corporificados através dos comportamentos dos indivíduos, precisariam ser constantemente reafirmados e nunca questionados, daí a necessidade de controlar o acesso às informações para aqueles que ainda não tivessem sido suficientemente moralizados e que, desta forma, poderiam aderir a idéias e a um modo de vida não desejáveis, não representassem um perigo para si e para os outros.

No final dos anos de 1970, período no qual a categoria profissional dos professores apresentava uma configuração mais combativa, o discurso acerca do sacerdócio ainda prevalecia. A representação da profissão docente como uma missão sublimava a doação e a abnegação e minimizava a reivindicação por melhores salários e as condições materiais nas quais era realizado o exercício do magistério. Entre os anos de 1960 e 1970, o conjunto dos referenciais de conduta dos professores se apresentava como uma exigência de regulação política que atendia a duas necessidades importantes: impor aos alunos um padrão de comportamento que eles deveriam seguir para que o sistema educacional conseguisse suportar a demanda que vinha recebendo e perpetuar entre os docentes atitudes de resignação e submissão às condições de trabalho cada vez mais desfavoráveis, simbólica e materialmente. Em relação à maneira como os autores dirigiam-se ao trabalho docente nas fontes consultadas, a mescla dos discursos que se pretendiam científicos com os de origem religiosa é evidenciada em muitos momentos, mas o fato de terem sido evocados tanto santos, como São Tiago e Dom Bosco, quanto pedagogos como Dewey e Pestalozzi, nos textos que buscavam orientar o exercício do magistério, é muito significativo acerca da maneira como os valores morais eram manejados para conquistar a adesão dos indivíduos a tais representações. Com relação à influência que o comportamento dos professores teria na formação moral dos alunos, assim como os sacerdotes, além de cuidarem da sua postura de modo a servirem de "exemplos vivos", os docentes também deveriam conquistar as crianças através do uso das palavras, "evangelizando", falando bem e apresentando uma boa dicção. 
Prática religiosa incorporada pelas escolas, a confidência, que era utilizada pelos padres no processo de evangelização, era empregada nas escolas primárias e moralizava ao ser transformada em confissão. Colocar a formação moral no centro de toda a ação educativa para civilizar, doutrinar e moldar os indivíduos que deveriam servir à pátria - ativava os valores cristãos que haviam sido utilizados pelos sacerdotes para conformar moralmente os fiéis. Assim, o magistério exigia dos educadores que tivessem fé no seu trabalho, uma confiança profunda nas possibilidades de progresso e elevação da natureza humana, e exigia dos alunos que tivessem fé nos seus professores, naquilo que eles faziam, diziam e principalmente no que representavam: a encarnação da moral. O que não era levado em conta pelos discursos enunciados nas fontes consultadas, na maioria das vezes, era que os professores faziam parte de todo um sistema de ensino, e este era em muitos casos desconsiderado, que transformavam a figura do professor de participante a protagonista de todo o processo educativo. Mais do que aquilo que ele sabia e poderia ensinar, o que seria decisivo para o sucesso na empreitada educativa, segundo as representações apresentadas pelas revistas pedagógicas e pelos manuais de didática, seriam os seus atributos pessoais: a sua personalidade, o seu caráter e mesmo a sua capacidade de suportar a dor e o seu próprio fracasso. Vivendo e trabalhando nas condições mais adversas e precárias, de acordo com os discursos veiculados nas fontes, escritos pelos próprios professores primários, eles aceitavam o seu trabalho como uma missão, da qual eles não poderiam reclamar, já que ela era revestida de tanta nobreza e compensação simbólica que não lhes dava o direito a qualquer reivindicação, causando reprovação da imprensa e de diversos setores da sociedade quando eles começaram a se mobilizar e a organizar as primeiras greves da categoria, buscando melhores salários (LUGLI e VICENTINI, 2009).

A "profissionalização" dos papéis maternos, representados pelas professoras primárias, contribuiria para a formação moral das crianças e seria de grande valia no período de expansão da escola. Para governar muitas crianças ao mesmo tempo, sem fazer uso de castigos físicos e de humilhações públicas, que eram severamente criticados, transpor para a escola o poder da autoridade materna consistiu em um dispositivo de governo dos alunos e de controle de sua subjetividade. Pelo afeto e pelo encanto de que dispunham as moças que saíam das escolas normais sobre os alunos, o "amor às crianças" nos anos de 1960 talvez tivesse a função da palmatória de outrora. E as crianças, pelo amor à professora, como se fossem a sua segunda mãe, obedeceriam e agiriam de acordo com a 
vontade da mestra, para o "bem" delas. A pedagogia do afeto exercida pelas professoras primárias poderia servir principalmente a dois propósitos: auxiliar as mestras a serem condescendentes com a nova clientela, que não trazia o instrumental necessário para decifrar a gramática escolar e não sabia comportar-se adequadamente neste espaço e consistir em uma recompensa simbólica graças a qual as professoras poderiam suportar as agruras e os sacrifícios exigidos pelo seu trabalho.

É importante ressaltar ainda, que diferente de outras profissões, nas quais o resultado decorrente da atividade exercida é um produto, algo produzido por uma pessoa a outra, ou mesmo um serviço prestado a alguém, no caso do magistério primário, o fruto do trabalho corresponde à apresentação de si, que envolve o controle e o cuidado de si. Algo semelhante ao que ocorre com a profissão dos atores acontece com aquela exercida pelos docentes. Diferente dos pintores ou dos escultores, que têm na sua obra, um quadro ou uma escultura, um produto material que expressa todo o trabalho realizado, os atores são eles próprios a sua obra. No teatro, as artes cênicas só existem com a presença dos atores, com a sua exibição concreta e física. Com os professores acontece algo semelhante: o desempenho do trabalho docente é indissociável da apresentação de si. Talvez por este motivo seja possível notar semelhanças entre o ofício de ensinar e a arte de representar: estilo, sedução e encanto são tão importantes aos atores quanto aos professores, ao menos nas formas prescritas pela literatura de formação do magistério. Também no caso das professoras primárias, elas seriam a sua própria obra. Nesse sentido, os professores não ensinavam apenas com o que sabiam, mas ensinavam também com o que eram e representavam.

O processo de urbanização pelo qual o Estado de São Paulo passava desde o início do século XX havia sido intensificado nos anos de 1950 e ampliado até os anos 1970. Aliados à urbanização, dois fenômenos também marcaram a configuração social no período: a migração (do norte e do nordeste do país para o sul e do interior para a capital) e a industrialização (PEREIRA, 1976; SKIDMORE, 1982). Vale a pena reiterar, como foi apresentado neste estudo, que elementos como o ingresso das mulheres no mercado de trabalho e a iminência de revoluções sociais, como a pretendida pelo movimento feminista, ajudam a compreender como um período que via o desenvolvimento industrial e a expansão demográfica contestar os valores sociais tradicionais, temia que as reivindicações femininas derivadas desse novo estilo de vida abalassem a instituição que era tida, tanto 
pelo Estado, quanto pela Igreja, como o alicerce do país. Além disso, na representação da família tradicional, aquela que normalmente era veiculada no material consultado, as mulheres eram as encarregadas dos rituais de manutenção do grupo familiar. Esse temor pela destruição ou pela mudança em sua estrutura era representado nos discursos apresentados nas fontes consultadas pela importância dada à figura das mães e ao seu papel na educação das crianças. Nesse momento histórico, esse elemento também pode ter contribuído para reforçar e perpetuar a idéia de que, nas escolas, as professoras primárias seriam uma espécie de segunda mãe dos seus alunos, contribuindo com o caráter inercial do habitus docente (PEREIRA, 1969; PEREIRA, 2001).

A necessidade da moralização era realmente imperativa, isso não era dito apenas aos professores para que formassem os alunos nestes moldes, mas também aos próprios estudantes. Crianças mais disciplinadas e moralizadas correspondiam à representação de que a escola funcionava bem e de que as professoras primárias estavam obtendo sucesso no ensino ministrado, apesar das adversidades e das condições materiais nas quais se realizava o trabalho docente. A moralização exercida nas escolas primárias deveria inculcar nas crianças o respeito pela regras impessoais e abstratas, habituando-as a dominarem-se e a conterem-se. As regras eram apresentadas aos alunos por intermédio daqueles que a encarnavam, no caso, os professores e, especialmente as professoras primárias. O que importava não era que a criança sofresse, mas que o seu ato fosse reprovado, pelo outro e depois por ela própria. A palmatória e os castigos físicos haviam sido substituídos por elementos muito mais eficientes que, ao invés de coagirem as crianças pelo medo, por ações direcionadas ao corpo, dirigiam a sua subjetividade, através da formação da vontade, da criação da necessidade e da vergonha, instaurando uma censura interna que controlava a sua alma. Essa condenação da conduta possuía um caráter reparador. Tal condenação estava presente no cotidiano escolar mediante sutilezas, expressões, sorrisos de aprovação, olhares de reprovação e exemplos, sendo o principal deles encenado pelas professoras primárias. Para regular o comportamento dos alunos, era preciso que elas desenvolvessem uma certa maestria de si, forjada pela disciplina moral, que as ensinava a conter e a resistir a si próprias.

Em artigo no qual trata da representação que as professoras primárias ainda têm na sociedade contemporânea, Eliane Teixeira Lopes (1991) diz o seguinte: "não somos missionárias - às vezes conseguimos nos lembrar disso -, não somos lindas e chiques, não 
somos boazinhas, não demos e não daremos conta de salvar a Humanidade ('Sem educação não há salvação!'), sequer a humanidade dos alunos ou de nós mesmas. Não somos o que o discurso religioso ou o discurso moderno nos ensinou que deveríamos ser. E se não somos isso e se não temos nenhum reconhecimento social (para não falar em salário) disso que somos dia a dia, concretamente, quem somos nós afinal? Todo mundo ajuda a construir uma certa imagem...mas quem mora nela somos nós" (op. cit., p. 174-175). É difícil resistir e não voltar à história do lobo. Ele também procurava saber quem ele era. Por mais que o preço a pagar pela origem da profissão fosse alto, as professoras primárias dificilmente conseguiam (e talvez dificilmente consigam ainda hoje) violar a sua moral porque isso punha em jogo não apenas a sua legitimidade como também a sua posição no campo educacional, mesmo que esta lhes fosse desfavorável. Marcado pela inércia, o habitus docente tende a manter as suas disposições, mesmo quando as condições sociais que a geraram mudaram ou desapareceram (PEREIRA, 2001). Desta forma, talvez as pessoas que davam vida à imagem das professoras missionárias tivessem querido um dia fugir, mas fugir diante de um cenário que estaria pronto para receber a "professora mãe" ou "o professor sacerdote", ou então representar um outro papel nesse teatro pareceria, como no caso no lobo, um espetáculo "só para loucos", e não seria possível representar dois papéis na mesma peça, exceto o de aluna no primeiro ato e professora no segundo. E assim, o passado voltava ao presente mediante as práticas que, mesmo servindo a um discurso que havia sido modificado ideologicamente, eram acionadas no momento da educação escolar, sendo corporificadas nos indivíduos e evidenciadas pelas suas representações. 


\section{REFERÊNCIAS BIBLIOGRÁFICAS}

ALMEIDA, Guido de. O professor que não ensina. São Paulo: Summus, 1986.

ANTUNHA, Heládio César Gonçalves. Instrução na primeira república: a união e o ensino primário São Paulo: S. N., 1975.

ÁVILA, Fernando Bastos de. Pequena enciclopédia de moral e civismo MEC/1967.

AZANHA, José Mário Pires. "Cultura escolar brasileira: Um programa de pesquisas". Revista da USP, São Paulo, nº 8, Dez. / Fev. 1990 - 1991, p. 65 - 69.

"Democratização do ensino: vicissitudes da idéia no caso paulista"

Educação: Alguns escritos. São Paulo: Editora Nacional, 1987.

"Roque Spencer Maciel de Barros: defensor da escola pública" Revista

Educação e Pesquisa, vol.25, nº1, São Paulo, jan./jun. 1999.

AZEVEDO, Fernando de. Reconstrução educacional no Brasil: ao povo e ao governo Manifesto dos Pioneiros da Educação Nova São Paulo: Nacional, 1932.

BARROS, Roque Spencer Maciel de. (org.) Diretrizes e Bases da Educação Nacional São Paulo: Pioneira, 1960.

BAUDELOT, Christian; ESTABLET, Roger. Allez les filles! Une révolution silencieuse Paris: Seul, 1992.

BAUBEROT, J. La morale laïque contre l'ordre moral Paris: Seuil, 1997.

Histoire de la laïcité em France Paris:PUF, 2008.

La morale laïque contre l'ordre moral sous la Troisième République Paris: Archives Karéline, 2009.

BEISIEGEL, Celso de Rui. A qualidade do ensino na escola pública Brasília: Liber Livro, 2005. 
Educação e Popular: um estudo sobre educação de adultos. São Paulo: Pioneira, 1974.

BERTHIER, Patrick. "Une morale sans fondement” Revue Recherche et Formation, INRP, Paris, $\mathrm{n}^{\circ} 52,2006$, p. $13-27$.

BISSERET, Noëlle. “A ideologia das aptidões naturais” In: DURAND, J. C. G. (org.) Educação e hegemonia de classe Rio de Janeiro: Zahar, 1979.

BOTO, Carlota. Ler, escrever, contar e se comportar: a escola primária como rito do século XIX português (1820-1910), tese de doutorado, FFLCH-USP, 1997.

BOURDIEU, Pierre. Questões de sociologia Rio de Janeiro: Marco Zero, 1981.

Coisas Ditas São Paulo: Brasiliense,1990.

A economia das trocas lingüísticas São Paulo: Edusp, 1996.

O amor pela arte: os museus de arte na Europa e seu público São aulo:

Edusp, 2003.

O poder simbólico $3^{\mathrm{a} e d . ~ R i o ~ d e ~ J a n e i r o: ~ B e r t r a n d ~ B r a s i l, ~} 2000$.

“As categorias do juízo professoral” In.: CATANI, A.; NOGUEIRA, M. A.

(Orgs.) Escritos de educação. Rio de Janeiro: Vozes, 1999, p. 185 - 216.

A economia das trocas simbólicas São Paulo: Perspectiva, 2005.

Esboço de uma teoria da prática Lisboa: Celta, 2006.

Razões práticas: sobre a teoria da ação Campinas: Papirus, 1996.

CARVALHO, Marília Pinto de. No coração da sala de aula: Gênero e trabalho docente nas séries iniciais São Paulo: Xamã, 1999.

CARVALHO, Marta Maria Chagas de. A Escola Nova e o impresso : um estudo sobre estratégias editoriais de difusão do escolanovismo no Brasil Belo Horizonte: Autêntica, 2001.

Escola e a república. São Paulo: Brasiliense, 1989.

Molde nacional e fôrma cívica: higiene, moral e trabalho no projeto da associação brasileira de educação (1924-1931) Bragança Paulista: EDUSF, 1998.

CAULFIELD, Sueann. Em defesa da honra: moralidade, modernidade e nação no Rio de Janeiro (1918-1940) Campinas: Editora da Unicamp, 2000. 
CASPARD, Pierre. "Éducation et progrès. Ce que disent les écrits personnels" Musée neuchâtelois, octobre 1996, pp. 273-289.

"Un modèle pour Ferdinand Buisson? La religion dans la formation des maîtres à Neuchâtel (XIXe siècle)"in J.F. Condette (Dir.): Éducation, religion, laïcité (XVIe-XXe s.). Continuités, tensions et ruptures dans la formation des élèves et des enseignants. Lille, CEGES, 2010, pp. 121-142.

CASPARD P., LUC J.-N., SAVOIE P. (dir.): Lycées, lycéens, lycéennes. Deux siècles d'histoire. Lyon, INRP, 2005

CASTRO, Ruy. Carmen: uma biografia São Paulo: Companhia das Letras, 2005.

CATANI, Denice Barbara. "A educação como ela é” Revista Educação, especial biblioteca do professor, 2008, p. $16-25$.

Educadores à Meia-Luz: um estudo sobre a Revista de Ensino da Associação Beneficente do Professorado Público de São Paulo (1902 - 1919). São Paulo: FEUSP, 1989, tese de doutorado.

(Org.) Educação em revista: a imprensa periódica e a história da educação São Paulo: Escrituras, 1997.

"Pierre Bourdieu e a História (da Educação)" In: FARIA FILHO, L. M. Pensadores sociais e história da educação Belo Horizonte: Autêntica, 2008.

CATANI, D. B.; SOUSA, C. P. (Orgs.) Imprensa periódica educacional paulista (1890/1996): catálogo São Paulo: Plêiade, 1999.

CAULFIELD, Sueann. Em defesa da honra: moralidade, modernidade e nação no Rio de Janeiro (1918-1940) Campinas: Editora da Unicamp, 2000.

CHARTIER, Roger. "O mundo como representação" Revista do Instituto de Estudos Avançados, 11 (5), 1991, p. 173 - 191.

A história cultural: entre práticas e representações, Lisboa: Difel, 1990.

COELHO, Maricilde Oliveira. Proclamar cidadãos: moral e civismo nas escolas públicas paraenses (1890-1910), dissertação de mestrado, FEUSP, 2004. 
DE LA TAILLE, Yves. et. al. "Construção da fronteira da intimidade: a humilhação e a vergonha na educação moral" Cadernos de Pesquisa, no 82, ago./1992, p. 43-55.

DEBRAY, R. L'enseignement du fait religieux dans l'école laïque Paris: Odile Jacob, 2002

DEWEY, John. Teoria da vida moral São Paulo: Ibrasa, 1960

Vida e educação São Paulo: Nacional, 1959.

Democracia e educação: introdução à filosofia da educação São Paulo: Companhia Editora Nacional, 1959.

DUBOIS, P. Le Dictionnaire de pédagogie et d'instruction primaire de Ferdinand Buisson - Répertoire biographique des auteurs Paris: INRP, 2002.

DUARTE, Geni Rosa. Rumo ao campo: a civilização pela escola, dissertação de mestrado, PUC-SP, 1995.

DURKHEIM, Émile. A Educação moral Petrópolis, RJ: Vozes, 2008.

L'évolution pédagogique en France Paris: PUF, 1990.

DUVAL, Nathalie. L'école des Roches Paris: Belin, 2009.

FARIA FILHO, Luciano Mendes de. Dos pardieiros aos palácios: forma e cultura escolares em belo horizonte (1906/1918), tese de doutorado, FEUSP, 1996.

"A legislação escolar como fonte para a História da Educação: uma tentativa de interpretação". In: FARIA FILHO, L. M. (org.) Educação, Modernidade e civilização: fontes e perspectivas de análises para a história da educação oitocentista. Belo Horizonte: Autêntica, 1998.

“A instrução elementar no século XIX”. In: Eliane Marta Santos Teixeira Lopes; Cynthia Greive Veiga; Luciano Mendes de Faria Filho. (Org.). 500 Anos de Educação no Brasil Belo Hoizonte: Autêntica, 2000, p. 35-53.

et al "A cultura escolar como categoria de análise e como campo de investigação na história da educação brasileira" Revista Educação e Pesquisa, São Paulo, n 1, vol. 30, Jan./Abr. 2004, p. 139 - 159. 
"O método mútuo e a formação docente no Brasil no século XIX: a qualificação da escola e a desqualificação do trabalho docente" Revista Educação em Foco, Juiz de Fora, vol. 7, n⿳0 02, Set./ Fev. 2002/2003, p. 3 - 17.

FERNANDES, Heloísa Rodrigues. Sintoma social dominante e moralização infantil São Paulo :Edusp/Escuta, 1994.

FOUCAULT, Michel Vigiar e Punir: nascimento da prisão. Petrópolis: Vozes, 1994.

GAILLE, M. Le citoyen Paris: Flammarion, 1998

GÉRARD, A. (org.) Permanence de la laïcité en France et dans le monde Toulouse: Privat, 2001.

GIL, Natália de Lacerda. Razão em números: a presença das estatísticas nos discursos educacionais divulgados na Revista Brasileira de Estudos Pedagógicos (1944-1952), dissertação de mestrado, FEUSP, 2002.

GILIOLI, Renato de Sousa Porto. Educação e cultura no rádio brasileiro: concepções de radioescola em Roquette-Pinto, tese de doutorado, FEUSP, 2008

HERNANDEZ, C.; GOUGAUD, J. La morale à l'école - 1905-1950 Paris: Berg International, 2009.

HESSE, Hermann. O lobo da estepe Rio de Janeiro: Record, 2010.

HILSDORF, Maria Lucia Spedo. História da educação brasileira: leituras São Paulo: Pioneira Thomson Learning, 2003.

"Mestra Benedita ensina primeiras letras em São Paulo (1828-1858)" 1' Seminário Docência, Memória e Gênero, GEDOMGE-FEUSP, São Paulo: Plêiade, 1996, p. 95-104.

JACOBSON, Lenore, ROSENTHAL, Robert. "Profecias auto-realizadoras em sala de aula: as expectativas dos professores como determinantes da competência intelectual” In: PATTO, Maria Helena S. (org.) Introdução à psicologia escolar. São Paulo: T. A. Queiroz,1981. 
JULIA, Dominique "A cultura escolar como objeto histórico" Revista Brasileira de História da Educação, Campinas, nº 1, p. 9 - 44, 2001.

LAHIRE, Bernard ; THIN, Daniel ; VINCENT, Guy. "Sobre a história e a teoria da forma escolar” Educação em Revista, Belo Horizonte, no 33, jun/2001, p. 7-47

LELIÈVRE, Claude. "Les profs, l'école et la sexualité" Revue Recherche et Formation, INRP, Paris, $n^{\circ} 52,2006$, p. $71-77$.

LÉVINE, Éva; TOUBOUL, Patricia. Le corps Paris: Flammarion, 2002.

LIMA, Ana Laura Godinho. De como ensinar o aluno a obedecer (um estudo dos discursos sobre a disciplina escolar entre 1944 a 1965), dissertação de mestrado, FEUSP, 1999.

O espectro da irregularidade ronda o aluno: um estudo da literatura pedagógica e da legislação sobre a "criança-problema", tese de doutorado, FEUSP, 2004.

"Testes ABC: proposta de governo para uma população problemática" Psicologia Escolar e Educacional, v. 11, 2007, p. 145-152.

LOURENÇO FILHO, M. B. Testes ABC para verificação da maturidade necessária à aprendizagem da leitura e escrita (12 ed.) São Paulo: Melhoramentos, 1974.

LOEFFEL, L. Ferdinand Buisson: Apôtre de l'école laïque Paris: Hachette, 1999.

LOPES, Eliane Marta Teixeira. "A educação da mulher: a feminização do magistério" Teoria e educação, $n^{\circ}$ 4, 1991, p. $22-40$.

"De Helenas e de professoras" Teoria e educação, n 4, 1991, p. 172 - 175.

LUGLI, Rosario S. G.; VICENTINI, P. P. História da profissão docente no Brasil: representações em disputa São Paulo: Cortez, 2009.

LUGLI, Rosario Silvana Genta. "A construção social do indivíduo” Revista Educação, especial biblioteca do professor, 2008, p. $26-35$. 
O trabalho docente no Brasil: o discurso dos Centros Regionais de Pesquisa Educacional e das entidades representativas do magistério (1950-1971), tese de doutorado, FEUSP, 2002.

LUC, J.-N.; NICOLAS, G. Le temps de l'école: De la maternelle au lycée 1880-1960 Luçon: Chêne, 2006.

MASCARO, Carlos Corrêa. O ensino normal no Estado de São Paulo: Subsídios para estudo da sua reforma Cadernos da FFCL/USP, 1956

MAYEUR, Françoise. Histoire générale de l'enseignement et de l'éducation en France. Tome III. De la Révolution à l'École républicaine (1789-1930). Paris: Perrin, 2004. (Collection tempus).

MERCIER, D. «L'enseignement de la morale au quotidien : le rôle des inspecteurs primaires, 1880-1914 » Revue Histoire de l'Éducation n ${ }^{\text {0 }}$ 105/jan.2005, p. 45 - 66.

MUEL-DREYFUS, F. Le métier d'éducateur Paris: Minuit, 1983.

NAGLE, Jorge “A educação na $1^{a}$ República”. In: FAUSTO, B. (org.) História Geral da Civilização Brasileira. São Paulo: EPU, 1976, p. 260 - 291.

NÓVOA, A.; SCHRIEWER, J. (orgs.) A difusão mundial da escola Lisboa: Educa, 2000.

NÓVOA, António. “A imagem do infinito: a lenta acomodação da profissão docente a uma identidade feminina" USP, 1996, mimeo.

“O passado e o presente dos professores" In.: NÓVOA, A. (org.) Profissão professor Porto: Porto Editora, 1995, p. 13 - 34.

OGNIER, P. Une école sans Dieu? 1880-1895: L'invention d'une morale laïque sous la IIIe. République, Toulouse: PUM, 2008.

OLIVEIRA, Maria Aparecida de Freitas Brisolla de. Política e Educação no Brasil: A implantação da obrigatoriedade da Educação Moral e Cívica no ensino brasileiro em 1969, dissertação de mestrado, FEUSP, 1982.

PEREIRA, Gilson. Servidão ambígua : valores e condição do magistério São Paulo : Escrituras, 2001.

PEREIRA, Luiz. A escola numa área metropolitana: crise e racionalização de uma empresa pública de serviços São Paulo: Pioneira, 1976. 
O magistério primário numa sociedade de classes. São Paulo : Pioneira, 1969.

PERRENOUD, Philippe. Práticas pedagógicas, profissão docente e formação: perspectivas sociológicas Lisboa: Dom Quixote, 1993.

PENA-RUIZ, H. La laïcité Paris: Flammarion, 2003.

PIAGET, Jean. O juízo moral na criança São Paulo: Summus, 1994.

PLATON. Timée Paris: GF-Flammarion, 1996.

ROMANELLI, Otaíza O. História da Educação no Brasil Rio de Janeiro: Vozes, 2007.

RAMOS DO Ó, Jorge. O governo dos escolares: Uma aproximação teórica às perspectivas de Michel Foucault Cadernos Prestige Lisboa: Educa, 2001.

RIBEIRO, Lusia Pereira Ribeiro. De donzela angelical e esposa dedicada... a profissional de educação, tese de doutorado, FEUSP, 1996.

SANTOS, Nelson Viana dos. Militarização da educação no Estado Novo, dissertação de mestrado, FEUSP, 1995.

SCHILLER, Friedrich. A educação estética do homem São Paulo : Iluminuras, 1995.

SILVA, Katiene Nogueira da. “Criança Calçada, Criança Sadia!”: Sobre os uniformes escolares no período de expansão da escola pública paulista (1950/1970) São Paulo: FEUSP, 2006, dissertação de mestrado.

SILVA, Marilda da. As experiências vividas em formação e a constituição do habitus professional: implicações para o estudo da didática, tese de doutorado, FEUSP, 1999.

SILVA, Vivian Batista da. "De como planejar a aula e aplicar métodos de ensino, segundo os manuais pedagógicos (1950 a 1971)" In: ALMEIDA, Jane Soares de Profissão Docente e Cultura Escolar. São Paulo: Intersubjetiva, 2004, p. 171 - 193.

Saberes em viagem nos manuais pedagógicos: construções da escola em Portugal e no Brasil (1870-1970), tese de doutorado, FEUSP, 2006.

SKIDMORE, Thomas. Brasil: De Castelo a Tancredo Rio de Janeiro: Paz e Terra, 1988.

Brasil: De Getúlio a Castelo Rio de Janeiro: Paz e Terra, 1982.

SODRÉ, N. W. Do Estado Novo à ditadura militar: Memórias de um soldado. Petrópolis: Vozes, 1988.

SOUSA, Rosa Fátima de. Templos de civilização: um estudo sobre a implantação dos grupos escolares no estado de São Paulo (1890-1910), tese de doutorado, FEUSP, 1996. 
SPOSITO, Marília Pontes O povo vai a escola: A luta popular pela expansão do ensino público em São Paulo São Paulo: Loyola, 1984.

STALLYBRASS, Peter O casaco de Marx: roupas, memória, dor Trad. Tomaz Tadeu da Silva, $2^{a}$ edição, Belo Horizonte: Autêntica, 2000.

TANURI, Leonor Maria. O ensino normal no Estado de São Paulo:1890-1930 Estudos e Documentos/USP, 1979.

"História da formação de professores" Revista Brasileira de Educação, n ${ }^{\circ}$ 14, mai./ago. 2000, p. $61-88$.

TAVARES, Fausto Antônio Ramalho. A ordem e a medida: escola e psicologia em São Paulo (1890-1930), dissertação de mestrado, FEUSP, 1996.

VICENTINI, Paula Perin. Imagens e representações de professores na história da profissão docente no Brasil (1933-1963), tese de doutorado, FEUSP, 2002.

Um estudo sobre o CPP (Centro do Professorado Paulista): profissão docente e organização do magistério (1930 - 1964), dissertação de mestrado, FEUSP, 1997.

VILLALOBOS, João Eduardo Rodrigues. Diretrizes e bases da educação: ensino e liberdade. São Paulo: Pioneira, 1969.

\section{MANUAIS PEDAGógicos}

D’ÁVILA, Antônio. Práticas Escolares 5ª edição São Paulo: Saraiva, 1949.

FONTOURA, Afro do Amaral. Didática Geral 8ª edição Rio de Janeiro: Aurora, 1965. 
FONTOURA, Afro do Amaral. Fundamentos da Educação: Princípios psicológicos e sociais, Elementos de Didática e Administração Escolar $3^{a}$ edição Rio de Janeiro: Editora Aurora, 1954.

FONTOURA, Afro do Amaral Metodologia do Ensino Primário. $6^{\text {a }}$ ed., Rio de Janeiro: Aurora, 1955.

GONÇALVES, Romanda. Didática Geral $13^{\mathrm{a}}$ edição $1^{\circ}$ volume São Paulo: Freitas Bastos, 1977 .

Didática Geral $12^{\mathrm{a}}$ edição $2^{\mathrm{o}}$ volume São Paulo: Freitas Bastos, 1977 .

Didática Geral $11^{\mathrm{a}}$ edição $3^{\circ}$ volume São Paulo: Freitas Bastos, 1977.

GRISI, Rafael. Didática Mínima 3ª edição São Paulo: Editora do Brasil, 1956.

LOURENÇO FILHO, M. B. Introdução ao Estudo da Escola Nova $11^{\text {a }}$ edição São Paulo: Melhoramentos, 1965.

MATTOS, Luiz Alves de. Sumário de Didática Geral $7^{a}$ edição Rio de Janeiro: Aurora, 1967.

NÉRICI, Imideo Giuseppe. Ensino Renovado e Fundamental $5^{\text {a }}$ edição São Paulo: Nobel, 1975.

PENTEADO, José de Arruda. Didática e Prática de Ensino: uma introdução crítica São Paulo: McGraw-Hill do Brasil, 1979.

PERRACINI, Aldo. A Escola Renovada: 10 anos de realizações na renovação do ensino São Paulo: Tabajara, 1972.

QUEIRÓS, Brisolva de Brito. et al Didática do Ensino Primário: Prática de Ensino $7^{\mathrm{a}}$ edição Rio de Janeiro: Conquista, 1960.

SANTOS, Teobaldo Miranda. Curso de Psicologia e Pedagogia: Manual do Professor

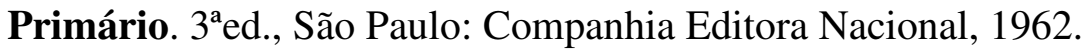


SANTOS, Teobaldo Miranda. Metodologia do Ensino Primário $5^{\text {a }}$ edição São Paulo: Companhia Editora Nacional, 1955.

\section{LEGISLAÇÃo}

"Conselho Federal de Educação: Estudos Sociais no Ensino de $1^{\circ}$ Grau" (Documentação) RBEP, nº 129, jan./mar. 1973, p. 148 - 152.

"Conselho Federal de Educação: Seleção de pareceres aprovados durante o trimestre". (Documentação) "Espetáculos para menores: critérios atualizados" RBEP, nº 95, jul./set. 1964, p. $154-164$.

"Conselho Federal de Educação: Seleção de pareceres aprovados durante o trimestre". (Documentação) "Educação moral e cívica - Parecer n 136/64, C.E.P. e M., aprov. em 56-1964”. RBEP, nº 95, jul./set. 1964, p. 116 - 139.

Decreto $\mathbf{n}^{\mathbf{0}}$ 38.538, de 29 de maio de 1961. Regimento Interno dos Estabelecimentos de Ensino Secundário e Normal do Estado de São Paulo.

Lei $\mathbf{n}^{0}$ 4.024, de 20 de dezembro de 1961. Fixa as Diretrizes e Bases da Educação Nacional.

Lei $\mathbf{n}^{\mathbf{0}} \mathbf{5 . 6 9 2}$, de 11 de agosto de 1971. Fixa diretrizes e bases para o ensino de $1^{\circ}$ e $2^{\circ}$ graus, e dá outras providências.

Decreto $\mathbf{n}^{0}$ 45.159-A, de 19 de agosto de 1965. Regimento Interno dos Estabelecimentos de Ensino Secundário e Normal do Estado de São Paulo.

Parecer no 117/64 - aprovado em 30/4/1964. O ensino da Educação Moral e Cívica em estabelecimentos de ensino médio. BRASIL.

Parecer no 136/64 - aprovado em 5/6/1964. Educação Moral e Cívica. BRASIL. 
Decreto n 5.884, de 21 de abril de 1933. Código de Educação do Estado de São Paulo.

Diretrizes e Bases da Educação Nacional. 1948.

Decreto n⿳ 58.023, de 21 de março de 1966 - Dispõe sobre a educação cívica. “Atos Oficiais" RBEP, nº 101, jan./mar. 1966, p. 140 - 141.

Decreto-Lei no 869/69, de 12/9/1969. Prescrições sobre currículos e programas básicos de educação moral e cívica nos três níveis de ensino. BRASIL.

BUZAID, A. Em defesa da moral e dos bons costumes. Ministério da Justiça. 1970.

Decreto-lei no 896, de 12/9/1969. Educação Moral e Cívica. BRASIL.

Decreto no 68065 - de 14 de janeiro de 1971. Regulamenta o Decreto-lei no 869, de 12-91969, que dispõe sobre a inclusão da Educação Moral e Cívica, como disciplina obrigatória, nas escolas de todos os graus e modalidades dos sistemas de ensino no País, e dá outras providências. (Legislação) RBEP, nº 122, abr./jun. 1971, p. 365 - 375.

\section{PERIÓDICOS EDUCACIONAIS}

Revista Brasileira de Estudos Pedagógicos, Instituto Nacional de Estudos Pedagógicos, Rio de Janeiro/Brasília, 1944- .

Revista do Professor, Centro do Professorado Paulista, São Paulo, 1934-1965. 